
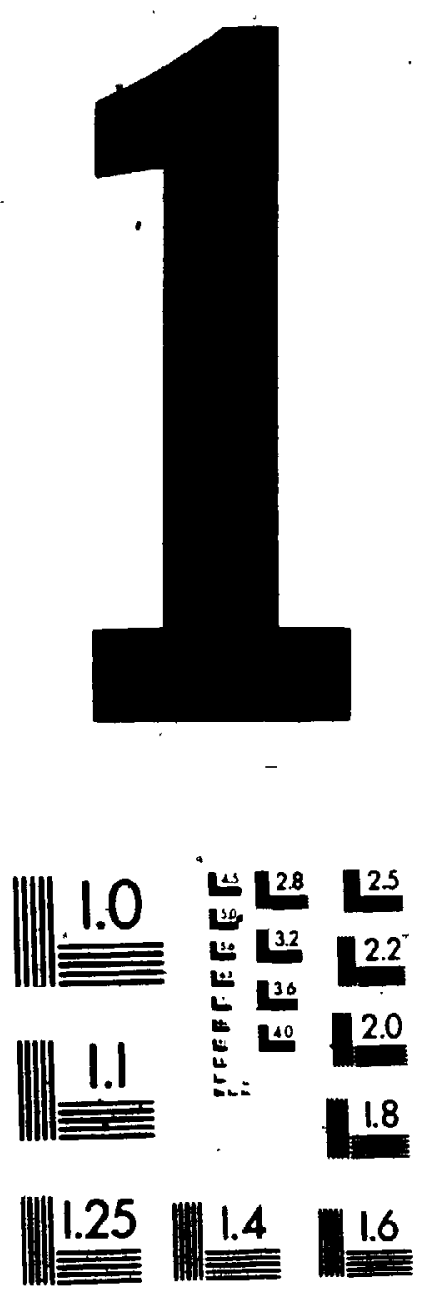
OHawa. Canada

K1A ON4

\section{CANADIAN THESES}

\section{THĖSES CANADIENNES}

\section{NOTICE}

The quality of this microfiche is heavily dependent upon the quality of the original thesis submitted for microfilming Every effort has been made to ensure the highest quality of reproduction possible

If pages are missing, contact the university which granted the degree

Some pages may have indistınct print especially if the original. pages were typed with a poor typewriter ribbon or if the university sent us an inferior photocopy

Previously copyrıghted materials (journal articles, publıshed tests, etc.) are not filmed.

Reproduction in full or in part of this film is governed by the Canadian Copyright Act, R S C. 1970; C. C-30 Please read the authorization forms which accompany this thesis;

\begin{abstract}
AVIS
La qualıte de cette microfiche dépend grandement de la qua' '. de ta thèse soumise au microfilmage Nous avons tout fait $p i$. assurer une qualite superieure de reproduction

S'll manque des pages, veullez communiquer avec l'unıersité qui a conféré le grade

La qualité d'impression de certaines pages peut laisser a désirer. surtout si les pages origınales ont été dacty̆lographiees à l'aıde d'un ruban usé ou si l'université nous a fart parvenır' une photocopıe de qualité inferreure

Les documents qui font déjà l'objet óun droit d'auteur (artıcles de revue, examens publies, etc.) ne sont pas microfilmes

La reproduction, même partielle, de ce microfilm est soumıse à la Lò canadienne sur le droit d'auteur, SRC 1970, C C-3C Veuillez prendre connaissance des formules d'autorisatıon quı accompagnent cette these
\end{abstract}

\section{THIS DISSERTATION HAS BEEN MICROFILMED EXACTLY AS RECEIVED}

\author{
LA THĖSE A ÉTÉ \\ MICROFILMÉE TELLE QUE \\ NOUS L'AVONS REÇUE
}

NL 338 (1 2001$)$ 
(3)

National Library

Bibliothèque rationale

$0-315-22171-2$

Theses Division Division does theses canadiennes

Ottawa Cong

PEnIMSEION TO MICROFILM - AUTORISATION DE MICROFILMER

Jerry Joseph Sykor $A$

Dec. 173 Banning $R d$. Kant $A, O C$

Stratigraphy, sedimentology and diggenesis-porosity relionshigs ot the subsurface Neocomian

Parsons Group, Mackenzie Delta, Are A,

Northwest Territories, Canada.

Contrition University

in $5 c$

1984

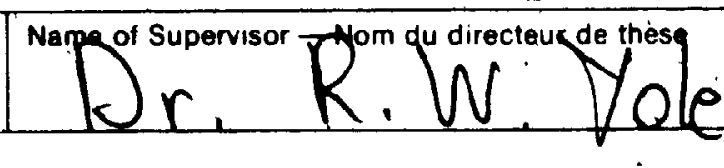

Permission is hereby granted to the NATIONAL LIBRARY OF

the film.

The author reserves other. publication rights. and neither the
thesis nor extensive extracts from it may be printed or other-

April $27 / 84$

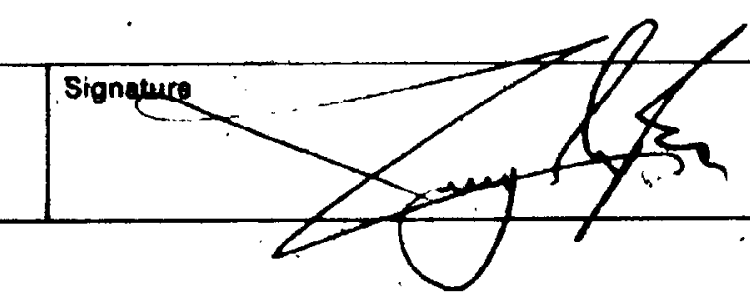


STRATIGRAPHY, SEDIMENTOLOGY AND DIAGENESISPOROSITY RELATIONSHIPS OF THE SUBSURFACE, NEOCOMIAN PARSONS GROUP, MACKENZIE DELTA AREA, NORTHWEST TERRITORIES, CANADA

$$
\text { by }
$$

(C) Jerry J. Sykora

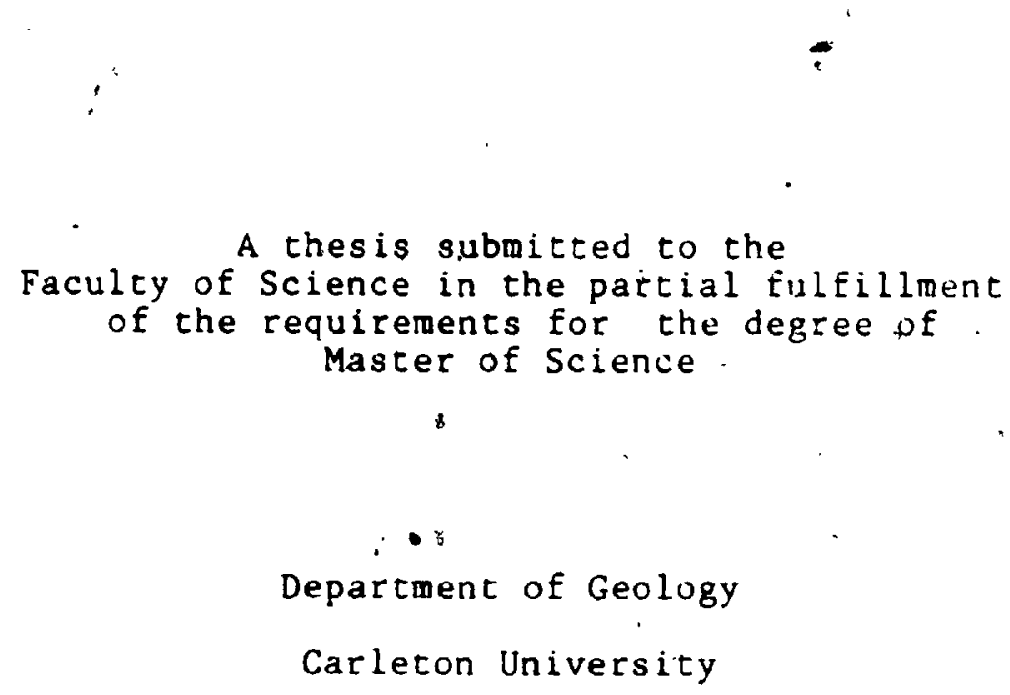


The undersigned recommend to the Faculty of Science acceptance of the thesis

" Sedimentology, stratigraphy and diagenesisporosity reletionships of the subsurface, Neocomian Parsons Group, Mackenzle Delta area, Northwest Territories, Canada

submitted by Jerry J. Sykora in partial tulfillment of the requirenents for the degree of Master of Science.

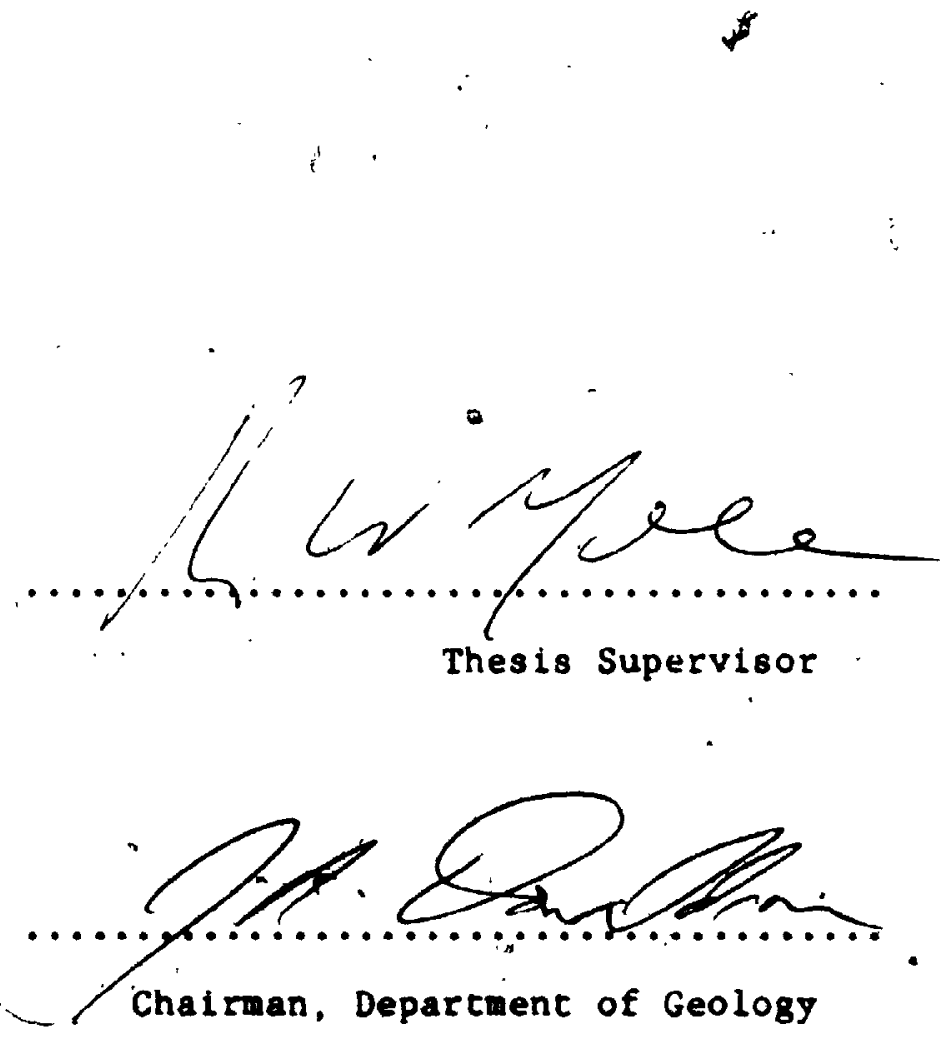

Carleton University

April, 1984 
The Lower Cretaceou Parsone Group 18.a ajor hydrocarbonbearing clastic equence, consisting of the Martin Creek, McGuTre and Ranik Fornatione. The Kantk Forpatioy to informally subdivided Into a sandstone-doninated lower nontarine mẹber., a" transitional aember, and a haly upper narine nember: "subiurface wapping of the parsons Group rocks is the nost detailed and complete to date, distingulshing the three Kamik Formation members.

Log interprétation, petrography and stratigraphy are used to define a variety of depositional environments, ranging from offshore in the McGuire Formation and the Ranik warine member through prograding barrier island in the Martin Creek Formation to high-energy braided-strean In the Kamik non-marine member. The sandstones studied are mosty quarte arenites, usually supernature, and show intragroup grain size differences related to depositional environments. Minor difterences in feldspar abundances possibly are related to diagenetic alteration.

Compaction, cementation ind dissolution are the majordiagenetic processes which have affected the sandstones. Differences in diagenetic "aseenblages" are related to grain size, composttion and probabiy most importantiy-burial depth. silica is the predoninent cenent with carbonate, lilitenontrorilionite and keolifice cenente preant as well. Dissolution of carbionete, which hes produced high gecondary porosicles, ean be related to burtal depth. 


\section{ACAMORLDGahars}

The bulk of the raw materials used in the fabrication of this thesis came from the research department and geological files of Gulf Canada Resources in Calgary. Without this ganerous accesspthis thesis would not have been possible. I woukdalso like to express my gratifgation speciflcally to Ross Lennox and Doug Gardner of Gulf Canada for the time allotted me during the summer of 1983 to work on thig thesis and to Bruce Hancock also of Gulf Canada for the discussions, time and physical contributions he made' to the work. Special thanks go to all staff members of the research department of Gulf Canada and to Monti Lerand for their interest and assistance in this thesis.

I would like to thank James Dixon of the Geological Survey of Canada in Calgary for suggesting such an interesting, challenging and pertinent topic.

The AAPG grantin aid program is acknowledged for their generous finencial contribution assisting the research of this thesia. Energy, Mines and Resources is thanked for the financial assistance given (research agreenent $46-1983$ ) during the course of this study.

Staff wemers of the core storage facility. Institute of Sedimentary and Petroleum Geology (GSC) in Calgary are mentioned In return for the promet and friendly service given ae during 
the weeks spent there logging core.

Staff nember of CoghA, especially Duncan Saith, are thanked for the easy access to files. and patient treatient of my requests.

My peers at Carleton University, especially Dr. G. Ŗoss, are much chanked for the endless geological discussions and support offered me during the investigation and writing of this thesis.. Peter Jones. is recognized for his assistance and opinions through-out the microprobe investigation of these rocks.

Thanks are given to De's J.A. Donaldson, T.J.S. Cole (Carleton. University) and.Dr. O.A. Dixon (Ottawa Universicy), for agreeing. to sit on wy defense board, and for the many suggestions on Improving the, cext.

Finally, special thanks are.given to Dr. R.W. Yole in recognition for both having me as a graduate gtudent" and for the many hours of critical assessuent, and numerous suggestions which greatly improved the quality and readability of the text. 


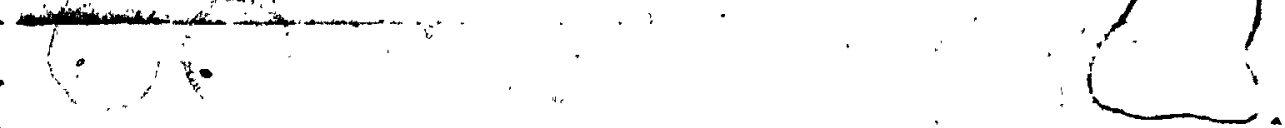

$+$

TABLE QF CONTENTS

TITLE PAGE ........................... page

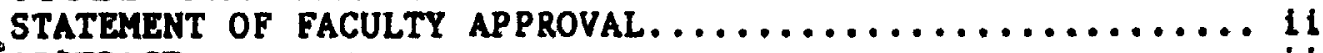

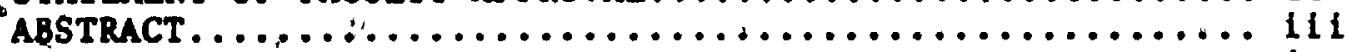

ACKNOWLEDGEMENTS ......................... Iv

TABLE OF CONTENTS .......................... vi

LIST OF ILLUSTRATIONS $\ldots \ldots \ldots \ldots \ldots \ldots \ldots \ldots \ldots \ldots \ldots \ldots$ vili

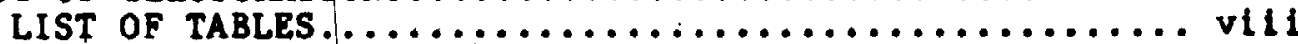

LIST OF FIGURES .......................... vili

LIST OF PLATES............................

LIST OF APPENDICES......................

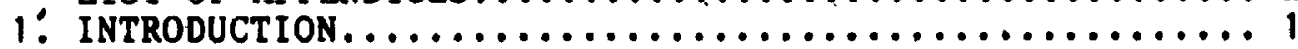

1.1 Purpoвe..............................

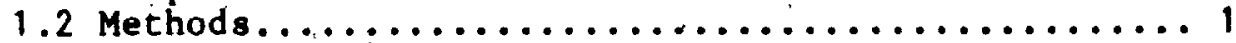

1.3 Geographic Setting.......................... 2

1.4 Selection of Boreholes....................... 2

1.5 Previous Work............................. 2

2. StRUCTURAL ELEMENTS Of THE MACKEnziE delta AREA...... 6

3. StRATIGRAPHY .......................... 9

3.1 General Introductian...................

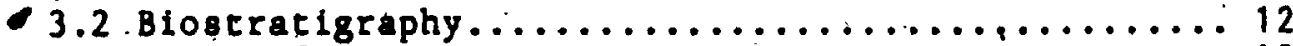

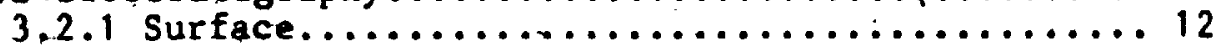

3.2 .2 Subsurface........................... 14

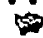

4. PETROGRAPHY.......................... 15

4.1 Methods of study........................ 15

4.1.1 Discussion of potential errors in composition. 15

4.1.2 Method of grain size analysis............ 16

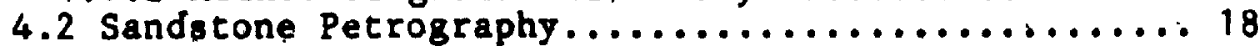

4.2 .1 Framework composition................ 18

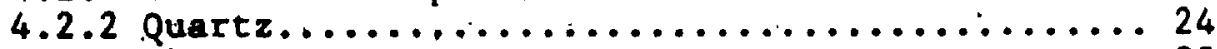

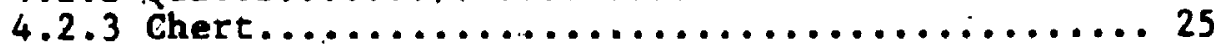

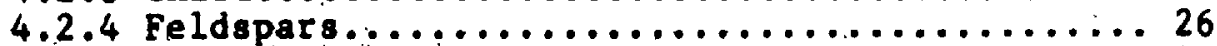

4.2 .5 Accessory minerals................. 26

4.2 .6 Minor rock fragments................ 26

4.3 Compositional Differences Among Stratigraphic

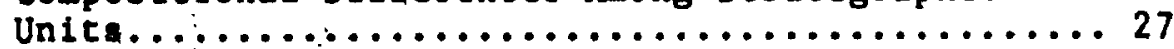

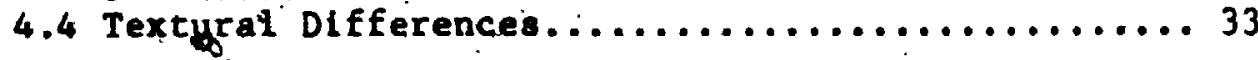

5. LITHOEACIES, DEPOSITIONAL PATTERNS, AND ENVIRONMENTS

OE DEPOSITION........................... 37

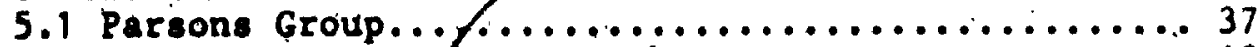

5.2 Husky Format Lon Upper Member................ 40

5.2.1 Environmenfal interpretation............. 44

5.3 Martín Creek Fermation:................... 44

5.3 .1 Depositional patterns................ 46

\$.3.2 Envitronmental interpretation............ 49

5.4 McGulre Formation....................... 51

5.4 .1 Depositional patterns ................ 52

5.4 .2 Enviromental interpretation............ 54

5.5 Kanik Formation......................... 55 
TABLE OF CONTENTS (cont inued)

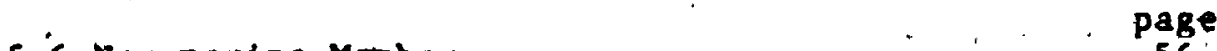

5.6 Mon-marine Huber.................... 56

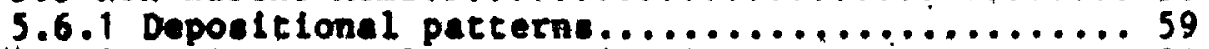

3.6.2 Envfromental Interpretation............6 61

5.7 Transitional Meaber....................... 64

5.7.1 Depoiltional patterns................. 73

5.7 .2 Environental Interpretation ............ 73

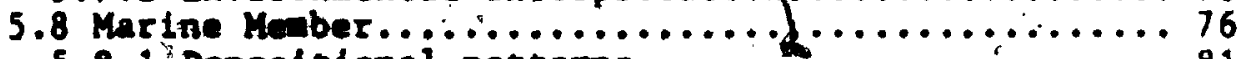

5.8.1 Depositional patterns...................81

5.8.2 Environental Interpretation............... 83

5.9 Sand Ioolithe........................ 84

6. DiAgenesis ............................ 90

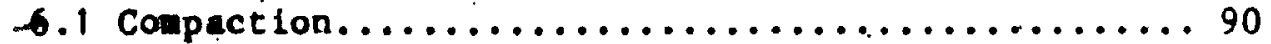

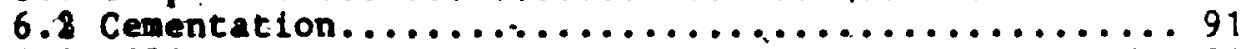

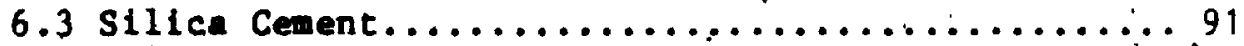

6.4 Caleite Cement........................93

6.5 Authigenic Clay Cement.................... 94

6.5 .1 Illite............................... 94

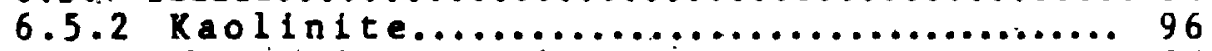

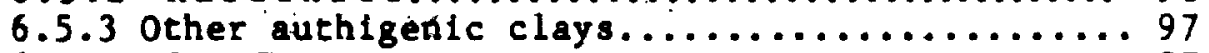

6.6 Hematite Cement........................ 97

6.7 Siderite Cenent...................... 97

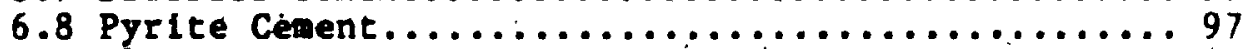

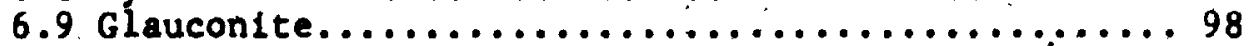

6.10 Replacement.......................... 98

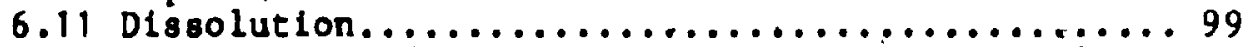

6.12 Paragenes is of Cements and Authigenic Minerals... 100

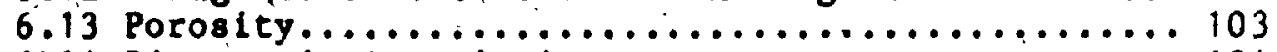

6.14 Diagenetic Association..................... 104

7. DIAGENESTS, AND THE PURSUIT OF POROSITY............ 109

7.1 Predicting Reservolr Porosity................ 109

7.2 Diagenetic Facies and Depch................. 111

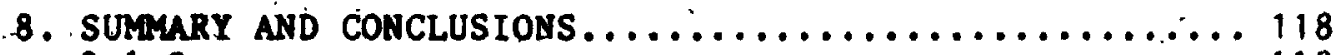

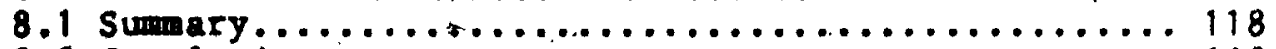

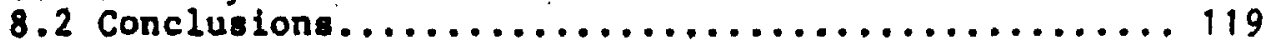

9. RECOMENDATIONS FOR FURTHER STUdY.............. 121

10. Plates................................. 122

11. REFERENCES ............................... 144

12. APPENDICES ................................... 149 


\section{LIST OF ILLUSTRATIONS}

\section{LIST OF TABLES}

page

Table 1. Table of sandstone composition and grain size analyses.......................... 20-22

Table 2. Environments of deposition in the transitional member................ 75

Table 3. Diagenetic maturity as a function of depth in the Parsons Group rocks..............................114

\section{LIST OF FIGURES}

Figure 1. General location map showing structural elements........................ 3

Figure 2. Geographic location map showing well locations and cross-sections............ 4

Figure 3. Generalized sttuctural contour map on top of Parsons Group strata.......... 8

Figure 4. Comparison of subsurface and surface lithostratigraphic terminology for Lower Cretaceous Formations........... 10

Figure 5. Detailed cross-section along the basinward flank of the Eskimo Lakes Arch ............................ pocket

Figure 6. Detailed cross-section across the Kugmallit Trough .................. in pocket

Figure 7. Stratigraphic profile of the Parsons Group rocks along the basinward flank of the Eskimo Lakes Arch and across the Kugmallit Trough................ 13

Figure 8. Probable error with 300 point counts...... 17

Figure 9. Error range for grain size measurements... 19

Figure 10 . Sandstone classification according to Folk (1968). Parsons Group............2 23

Figure 11. Ternary diagram of Martin Creek Formation sandstone compositions....... 28

Figure 12. Ternary diagram of non-marine member sandstone compositions.............. 29

Figure 13. Ternary diagram of transitional member sandstone compositions.............. 30

Figure 14. Ternary diagram of marine member sandstone compositions............. 31

Figure 15. Ternary diagram of sandstones from figures 11 to 14 with mean grain sizes between $0.10 \mathrm{~mm}$. and $0.20 \mathrm{~mm} \ldots \ldots \ldots 32$

Figure 16. Ternary diagram of sandscones from figures 11 to 14 with mean grain sizes between $0.10 \mathrm{~mm}$. and $0.20 \mathrm{~mm}$. and with oversized moldic porosity calculated as detrital feldspar............... 34

Figure 17. Distribution of mean grain size amongst sandstone-bearing units of the Parsons Group........................ 36

Figure 18. Isopach map of the Parsons Group....... 38 Figure 19. Legend for graphic display of core.....4 41 


\section{LIST ÓF ILLUSTRATIONS (cont inued)}

LIST OF FIGURES(continued)

Pigure 20. Graphlc display of core from the upper member, Husky Formation, Martin Creek Formation, and McGuire Formation... 42

Figure 21. Isopach map of upper member, Husky Formation and Martin Creek Formation....447

Figure 22. I sopach map of Martin. Creek Formation.... 48

Figure 23. I sopach map of McGuire Formation....... 53

Figure 24. Graphic display of core frow the nonmarine nember, Kamik Formation........ 57

Figure 25. Isopach map of non-marine member.......660

Figure 26. Graphic display of core from the lower and middle transitional member, Kamik

(a) Formation....................66

Figure 27. Graphic display of core from the upper transitional member, Kamik Formation.....667

Figure 28. Isopach map of transitional member..... 72

Figure 29. Graphic display of core from the marine member, Kamik Formation(E-21,G-04,P-41). 77

Figure 30. Graphic display of core from the marine member, Kamik Formation( $L-43, F-18, E-54$,

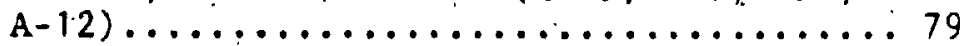

Figure 31. Isopach map of marine member.........882

Figure 32. Sandstone isoliths for non-marine member. 86

Figure 33. Sandstone isoliths for transitional member...................... 88

Figure 34. Sandstone isoliths for marine member....8 89

Figure 35. Communality chart showing associations among various petrographic features in the Parsons $\mathrm{N}-10$ well................. 105

Figure 36. An association tree (based upon figure 35) with porosity at the base.......... 108

Figure 37. Graph of porosity variations as a function of grain size............. 110

Figure 38. Diagenetic evolution (cycle) of

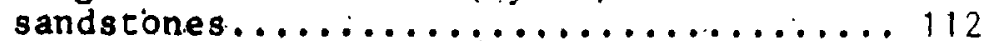

Figure 39. Maximum porosity potentiat of Parsons Group sandstones (quartz arenites) versus depth of burial.............. 115

Figure 40. Estimated distribution of porosity development in the subsurface Parsons Group

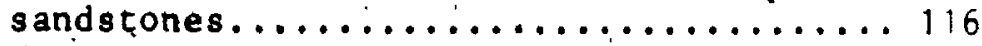

- Figures 41 to 59. Detailed graphic display of core..In Pocket

Figure 41. IOE Tuktu $0-19$ and Parsons $N-10$

Figure 42. Tullugak $k-31$

Figure 43. Parsons $\mathrm{N}-10$

Figure 44. Parsons N-10

Figure 45: Parsons F-09

Figure 46. Parsons $N-10$

Figure 47. Parsons L -43 
LIST OF ILLUSTRATIONS(continuèd)

LIST OF FIGURES(continued)

Figure 48. Wagnark $\mathrm{C}-23$ and Ikhil I-37

Figure 49. Siku E-21

Figure 50. Parsons $L-43$ and Siku E-21

Figure 51. Parsons F-09

Figure 52. Siku A-12

Figure 53. Ogruknang $M-31$ and Wagnark $C-23$

Figure 54. Reindeer $A-01$ and [OE Tuk F-18

Figure 55. Reindeer G-04

Eigure 56. Parsons $P-41$

Figure 57. Siku A-12

Figure 58. Parsons L-43

Figure 59. IOE Tuk E-18, IOE Pikiolik E-54 and Siku E-21

\section{LIST OF PLATES}

Plate 1. A 3.5 metre interval of core from the non-marine member in Ikhil $1-37 \ldots \ldots \ldots \ldots 122$

Plate 2. A 4.5 metre interval of core from the: transitional member in Siku E-21........ 124

Plate 3. A 4.4 metre interval of core from the transitional member in Siku A-12........ 126

Plate 4. Inorganic sedimentary structures and cextures in cores.................. 128

Place 5. Trace fossils in cores.............. 130

Plates 6 Scanning electron photomicrographs and

to 11 . thin section photomicrographs of constituents, textures, and porosities..... 132-

LIST OF APPENDICES

Appendix 1. Stratigraphic tops used in study....... 149

Appendix 2. Biostratigraphic summary.............. 160

Appendix $3 . x$-ray analyses................... 167 


\section{INTRODUCTION}

\subsection{Purpose}

This study was undertaken to investigate the sedimentary petrology and stratigraphy of the Neocomian age Parsons Group based on boreholes in the Kugmallit Trough, southeastern Beautort-Mackenzie Basin, and supplemented with outcrop data in the Richardson Mountains. By sedimentary petrography, and stratigraphic-sedimentological analysis the distribution and cörcelation of stratigraphic units', lithofacies, environments of deposition, diagenetic history, and associations were determined.

\subsection{Methods}

The Parsons Group was identified in the subsurface by well-to-well correlation using well logs, biostratigraphic data, and lithology where possible. Over one thousand feet of core were examined identifying sedimentary structures, Lthological characteristics, and trace fossils (ichnology) based on comparison with illustrations in Chamberlain (1978). Over two hundred specially impregnated thin sections of both core arid chip samples were studied using petrographic microscopy, and of these, forty-nine were investigated quantitatively. Selected samples were examined by scanning electron microscopy and $X-r a y$ analysis. 


\subsection{Geographic Setting}

The Kugmallit Trough is situated in the southeastern Mackenzie Delta-Beaufort Sea area, east of the Yukon-Northwest Territories border (Figures 1 and 2 ). It is bound on the. southeast by the Eskimo Lakes Arch and the Interior Plains and to the west by the Richardson Mountains. The area of detailed study is outlined in Figure 1.

\subsection{Selection of Boreholes}

Fifty boreholes, penetrating either Parsons Group strata or adjacent rocks (whose interpretation better define the petrology of the Parsons Group) were examined in the course of the study. These wells ( 1 isted in Appendix 1) provide the data for a comprehensive stratigraphic-sedimentological analysis.

\subsection{Previous Work (summarized after Dixon, 1982)}

Jeletzky $(1958,1960,1961,1967,1974,1975,1980$, in prep.) was the first investigator to study the stratigraphy of the Parsons Group lithostratigraphic equivalents in the Richardson Mountains, where he defined numerous units and proposed a geological history. Initial subsurface studies by Lerand (1973)", Myhr and Gunther (1974), Coté et al. (1975), Myhr and Young (1975), and Brideaux and Myhr (1976), presented general or locally specific information on the nature of the Parspns Group. Research was encouraged by the major discovery of the Parsons Lake gas field in the early to mid seventies. Young et al. (1976) compiled a regional synthesis of surface and subsurface data which included the Parsons Group. The first comprehensive 


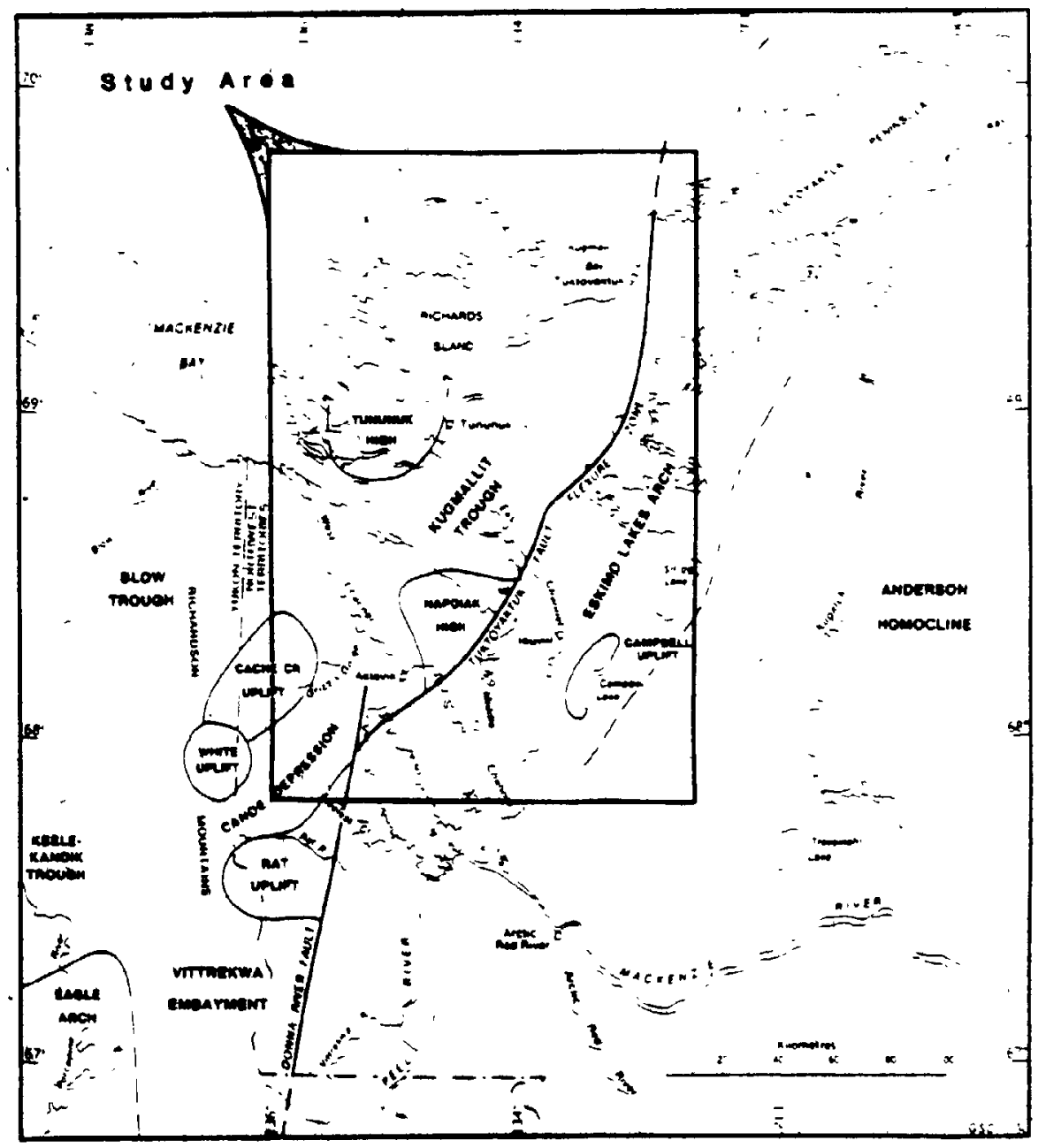

Figure 1. Gerieral location map showing structurai eleinents (from Dixon, 1982b, Figure 2) 


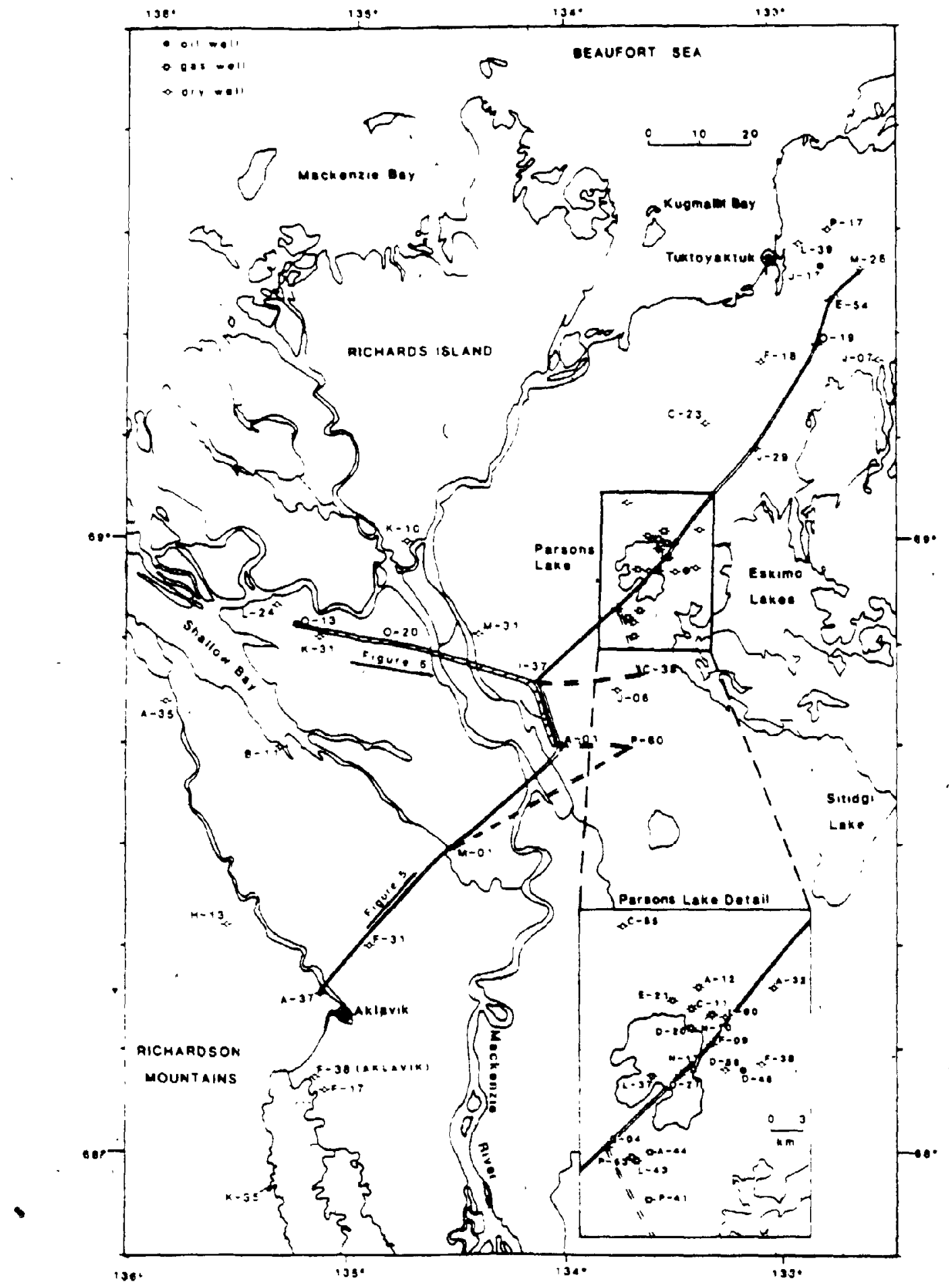

Figure 2. Geographic location map showing well locations and cross-sections 
stratigraphic-sedimentological study of the Parsons Group was attempted by Dixon (1982 a and b).

Litcle work has been published on the petrographic aspects of Parsons Group rocks. Schmidt and McDonald (1979) in their benchmark study of secondary porosity in sandstones used some Parsons Group rocks as examples. 'Dixon (1982a), described sore petrographic characteristics of the sandstones. In both of these publications the quartz-rich nature of sandstones in the Parsons Group was recognized, but the mineralogy was not fully assessed. 


\section{STRUCTURAL ELEMENTS OF THE MACKEIZIE DELTA AREA}

The structural terminalogy used here (Figure 1) is from is Dixon (1982b, Figure 2).

In the region studied, thickest Early Cretaceous deposits are in the Kugmallit Trough, a northeast - southwest trending depression flanked to the southeast by the Eskimo Lakes Arch, a positive feature throughout the deposition of the Parsons Group.

The northwest, basinward margin of the Eskimo Lakes Arch is bounded sharply by a major fault zone referred to as the Tuktoyaktuk Fault-Flexure Zone (Lerand, 1973). The timing of this faulting in relation to the evolution of the Eskimo Lakes Arch is uncertain, but some contemporaneous movement during Parsons Group deposition is probable Young et al. (1976, p.6) suggested that the Kugmallit Trough" was a Jurassic Columbian element. Isopach trends of Jurassic strata, mapped by Dixon (1982), suggest that the Eskimo Lakes Arch was a positive feature throughout Jurassic time. Young et al. (1976, p.6) concurred that a Jurassic arch was present but were uncertain of its relationship to the Columbian Orogen. Configuration of the Kugmallit Trough is locally affected by the Tununuk High to the northwest and by the'Napolak High, Cache Creek Uplift and Canoe Depression to the southwest. Thinning of Parsons Group rocks in the western part of the study area implies a possible structural linkage between the Cache Creek Uplift and the Tununuk High (see 
Young et al..1976, Figure 2), expressed as a less negative saddle separating the Kugmalite Trough proper to the northeast from the Blow "Trough to the southwest, Figure 3 is a grossly generalized atructural contour map on the top of the parsons Group atrata. Dominating the structure is the Tuktoyaktuk. Fault-Flexure ione. The throw across this zone can be in excess of 1 kilometer. "Coté et al.(1975,p.616) suggested that throws up to 2400 metres exist across the fault zone.

The western Kugmallit Trough was most likely uplifted during the, Late Cretaceous-Early Tertiary Laramide orogenic event in the Richardson Mountains, causing Parsons Group strata to dip to the northeast. The post-parsuns remant of the Kugmallit Trough is recognized just west of Parsons Lake (Figure 3).

Structure maps in the Parsons Lake area. (Figure 3) near the Tuktoyaktuk Fault-Flexure Zone, show numerous subsidiary"faults of varlous displacements associated with the major fault zone. These faults may persist in abundance basinward. 


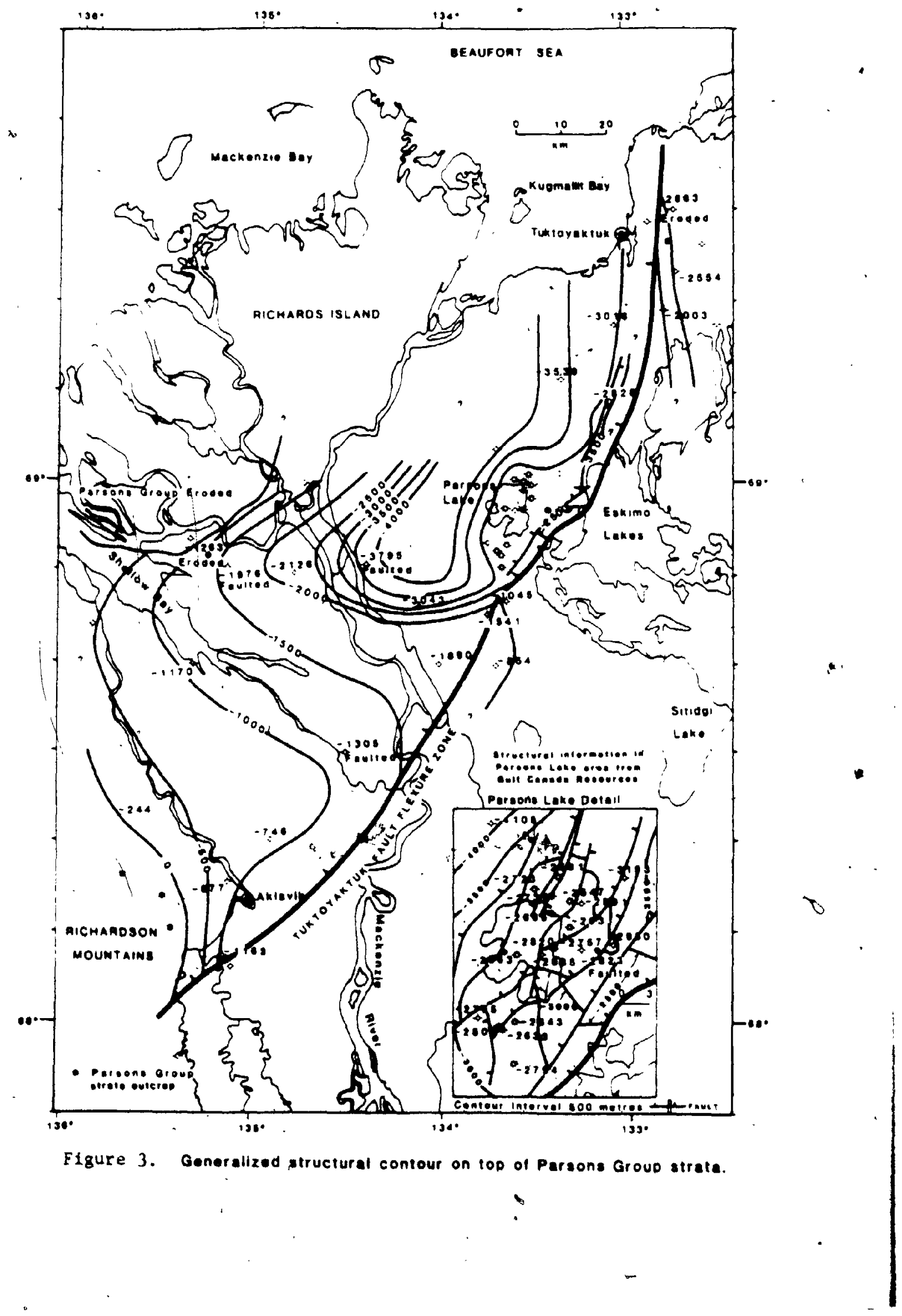




\section{STRATIGRAPHY}

\subsection{General Introduction}

Nomenclature for lithostratigraphic equivalents of Parsons Group strata exposed in the Richardson Mountains was developed by Jeletzky (1958, 1960,1961, 1967, 1980, and in prep.). Correlations to the subsurface were first presented by Coté et al., (1975) who proposed "Parsons Sandstune" as a name for the sand-dominated unit now recognized as the Parsons Group. Young et al., (1976), and most recently Dixon (1982b) have further modified the nomenclature.

Figure 4 summarizes the lithostratigraphic nomenclature proposed by Dixon (op. cit.) for Lower Cretaceous rocks in the subsurface of the Mackenzie Delta region, and for the northern Richardson Mountains lithostratigraphic equivalents. Minor modifications are proposed for nomenclature of the subsurface Kamik Formation in this thesis.

Subsurface correlations used in this repot are based on previous work by Dixon (1982b) in the subsurface of the Mackenzie Delta region. Stratigraphic tops in the wells used are given in Appendix 1. The present study involved mapping units within the Parsuns Group that differ in three ways from those used by Dixon (1982). First, the upper member of the Husky Formation and the Martin Creek Formation of the Parsons Group have been mapped together in recognition of their depositional continuity and 


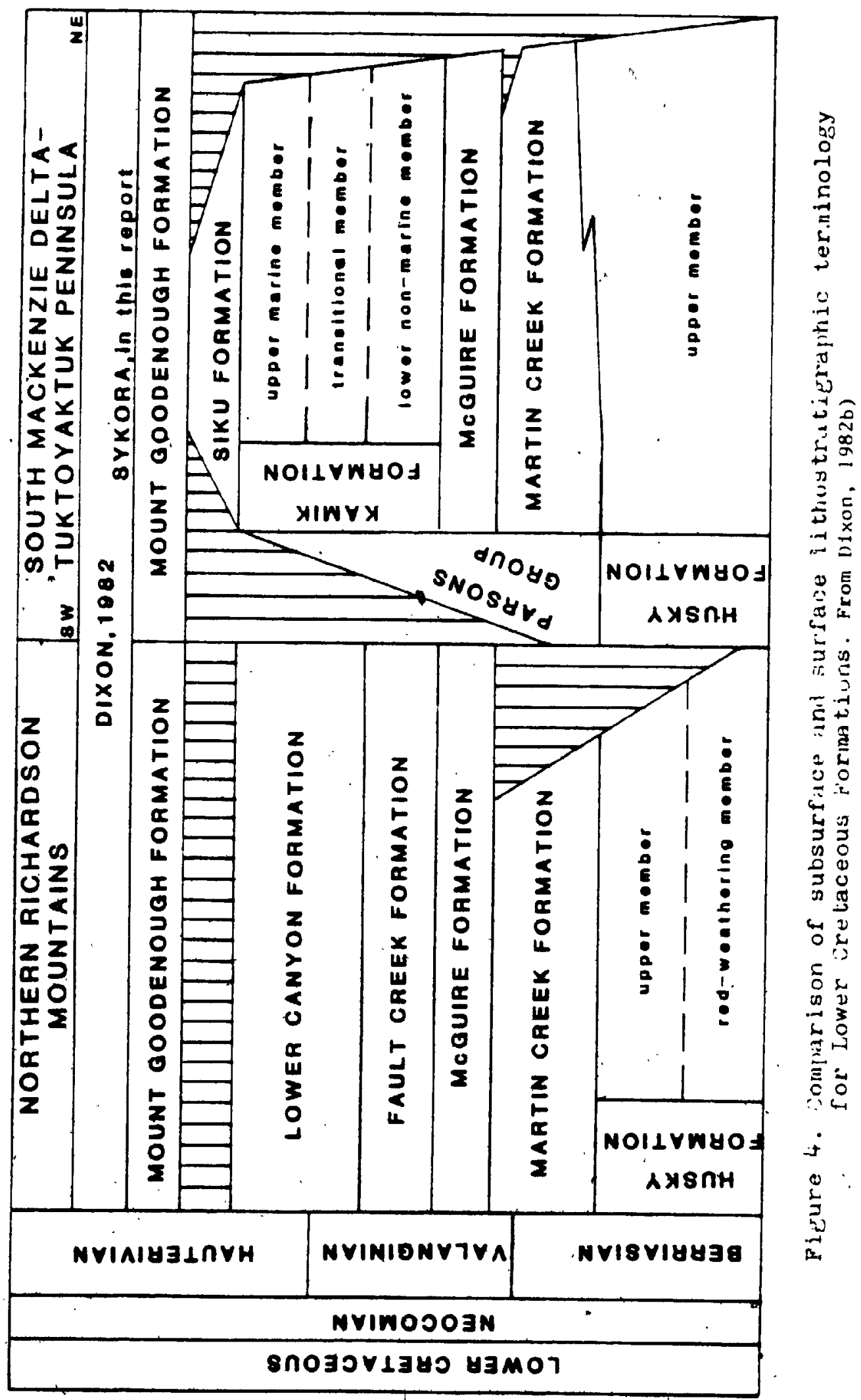


resultant gradational contact. Secondly, the Kamik Formation. has been divided into three members; a lower non-marine member. a cransitional member, and an upper marine member.

Myhr and Young. (1.975) first noted that the Kamik Formation stratigraphic equivalent was divisible into marine and non-marine, laterally continuous units in the subsurface. Dixon (1982b, p.18) noted that the basal, non=marine section of the Kamik Formation can be verfically divided into two parts distinguishable by sandstone characteristics and overall sand percentages. He also recognized mappable horizons within the upper two thirds of the Kamik Formation, at least in the Parsuns Lake area. Surface equivalent of the Kamik Formation can be simflarly divided into, three successive units corresponding to those seen in the subsurface (Dixon, 1982b, Figure 4). The Fault Creek Formation is lithologically equivalent to the nonmarine member of the Kamik while the overlying Lower Canyon Formation can be divided into a lower coal-bearing sandstonesiltstone-shale part and a marine shale-dominated upper part. Dixon (1982b) considered subdivision of the Kamik Formation to be impractical. However, it is proposed here that recognition of the three wembers is possible over the entire subsurface extent of the Kamik Formation.

Thirdly, the basin margins have been conservatively reinterpreted to fit a depositional interpretation for the Parsons Group, strata, which is more complete than was earlier available. 
Correlations presented here are controlled by available biostratigraphic determinations, down-hole, $\log$ responses to lithology, and petrography. They were extended throughout the study area by construction of stratigraphic cross-sections.

Figures 5 and 6 are detailed crose-sections along the short and long axes of the Kugmallit Trough. Figure 7 is a schematic representation of these cross-sections.

\subsection{Biostratigraphy}

\subsubsection{Surface}

Jeletzky (1958, 1960, 1961, 1975) has dated strata in the Richardson Mountains lithologically equivalent to Parsons Group using macro-fossils, as Neocamian in age.

Martin Creek-equivalents were dated Late Berriasian to Early Valanginian in Jeletzky's earlier work. Dixon (1982b, p.16) suggested that at this stage in Jeletzky's work, McGuire Formation equivalents had not been recognized.' Jeletzky (1961) subsequent to the recognition of the McGuire Formation, assigned an Early to Lace Berriasian age to Martin Creek equivalents.

Basing his conclusions on stratigraphic position and index fossils in the lower beds, Jeletzky assigned an early to Middle Valanginian age to equivalents of the McGuire Formation.

The lack. of fosslis in the kamik equivalents forced Jeletzky (1960, 1961) to rely on stratigraphic position to dace 


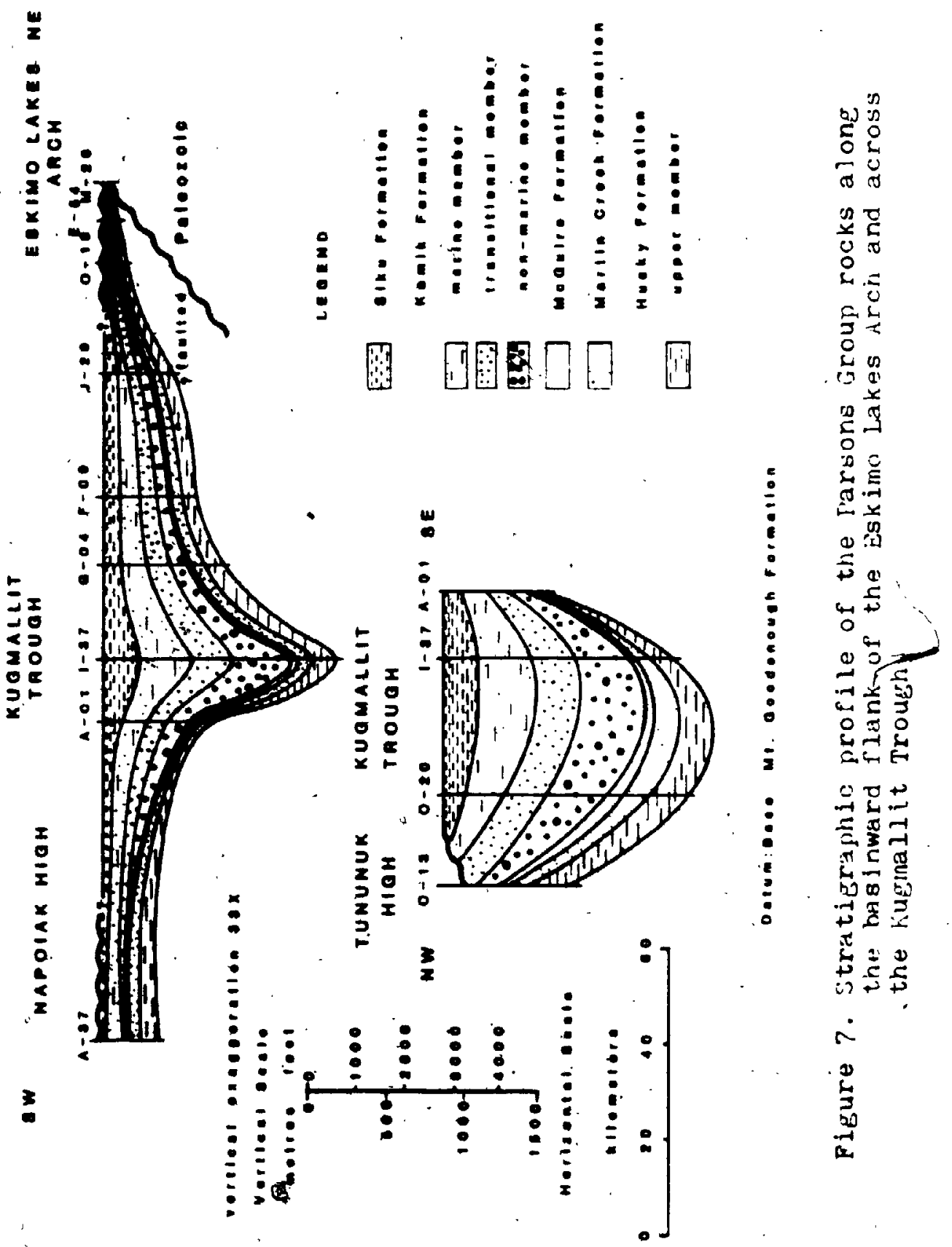


the Kamik as Middle or Late Valanginian to Middle Hauterivian in age. The upper member of the Coal-bearing Division, stratigraphically equivalent with the marine member of the Kamik, contalns belemnites of posslble Middle Hauterivian age (Jeletzky, 1960, p. 9).

\section{- 3.2.2 Subsurface}

Biostratigraphic inforration concerning the age of Parsons Group strata in the subsurface is drawn from - Barnes et al. 1974; Myhr and Gunther, 1974; Brideaux et al., 1975; Brideaux et al., 1976; Brideaux and Myhr, 1976 and unpublished biostratigraphic work by Gulf Canada Resources, Calgary.

Biostratigraphic information exists for sixteen wells, either penetrating Parsons Group strata, or occuring at basin margins where ages of contiguous strata are significant, to the interpretation of basinal sediments.

The biostratigraphic information compiled in Appendix 2 in combination with 108 responses and petrographic data form the framework for the stratigraphic correlations of the subsurface Parsons Group strata. Blostratigraphic determinatons have been adhered to unless clearly unreliable. Age estimates of subsurface Parsons Group rocks are very similar to those obtained from outcrop. 


\section{PETROGRAPHY}

\subsection{Methods of Study}

Parsons Group sandstones were investigated using thin section petrography, scanning electron microscopy, $x-r a y$ diffraction, and microprobe analysis.

Approximately 315 metres (1030 feet) of core from 17 wells were examined. Of 200 thin sections from 11 wells in the Parsons Lake area, 57 were selected for detailed study and of these 49 examined thoroughly with quantitative techniques. Most thin sationed samples were impregnated with blue epoxy to facilitate the recognition of porosity and to preserveof delicate authigenic clays during thin section preparation.

Mineral composition of authigenic clays was determined by petrographic microscope, SEM examination, X-ray diffraction and limited microprobe work.

Composttional analysis was achieved by recording 300 points on an approximate $2.5 \times 1.5 \mathrm{~cm}$. grid with an automatic point- count mechanical stage. Three hundred points were deemed sufficient based on the relative low compositional variability.

$\therefore \quad-27$

\subsubsection{Discussion of potential errors in composition}

Chayes (1956) deduced that for point count analyses true analytical error $(\sigma a)$ was a function of both counting ${ }^{\circ}$ error $\left(\sigma_{c}\right)$ and sampling error ( $\left.\sigma_{s}\right)$ (ie. $\left.\sigma_{a}=\sigma_{c}+\sigma_{s}\right)$. 
The sampling error can be kept to a minimum if a coarse meshed grid is used (Chayes 1950, Hilliard and Cahn 1961) allowing that the distance between points exceeds the maximum grain size.

Countingerror can be closely approximate $(p(1-p / n))^{1 / 2}$ (Chayes, $1956, p .90)(p=$ calculated percentage, n=number of point counts).

$$
\begin{aligned}
& \text { Since } \sigma_{a}=\sqrt{\sigma_{s}^{2}+\sigma_{c}^{2}}, \quad \sigma_{a}=\sqrt{\sigma_{s}^{2}+p(1-p) / n} \\
& \text { If } \sigma_{s} \text { can be assumed as zero then } \sigma_{a}=(p(1-p) / n)^{1 / 2}
\end{aligned}
$$

Figure 8 is a graphical representation of the probable. ininimal error as a function of calculated percentage, based upon a point count of 300 .

\subsubsection{Method of grain size analysis}

The longest apparent grain dimension was measured to compensate for the variation in grain orientation within and between samples. Measurements. were made using a micrometer eyepiece. Detrital components visibly modified by compaction were not measured. All measurements yield apparent grain sizes from thin sections.

A minimum of 50 grains were measured for each of the thin sections selected for detailed study. Samples exhibiting less 


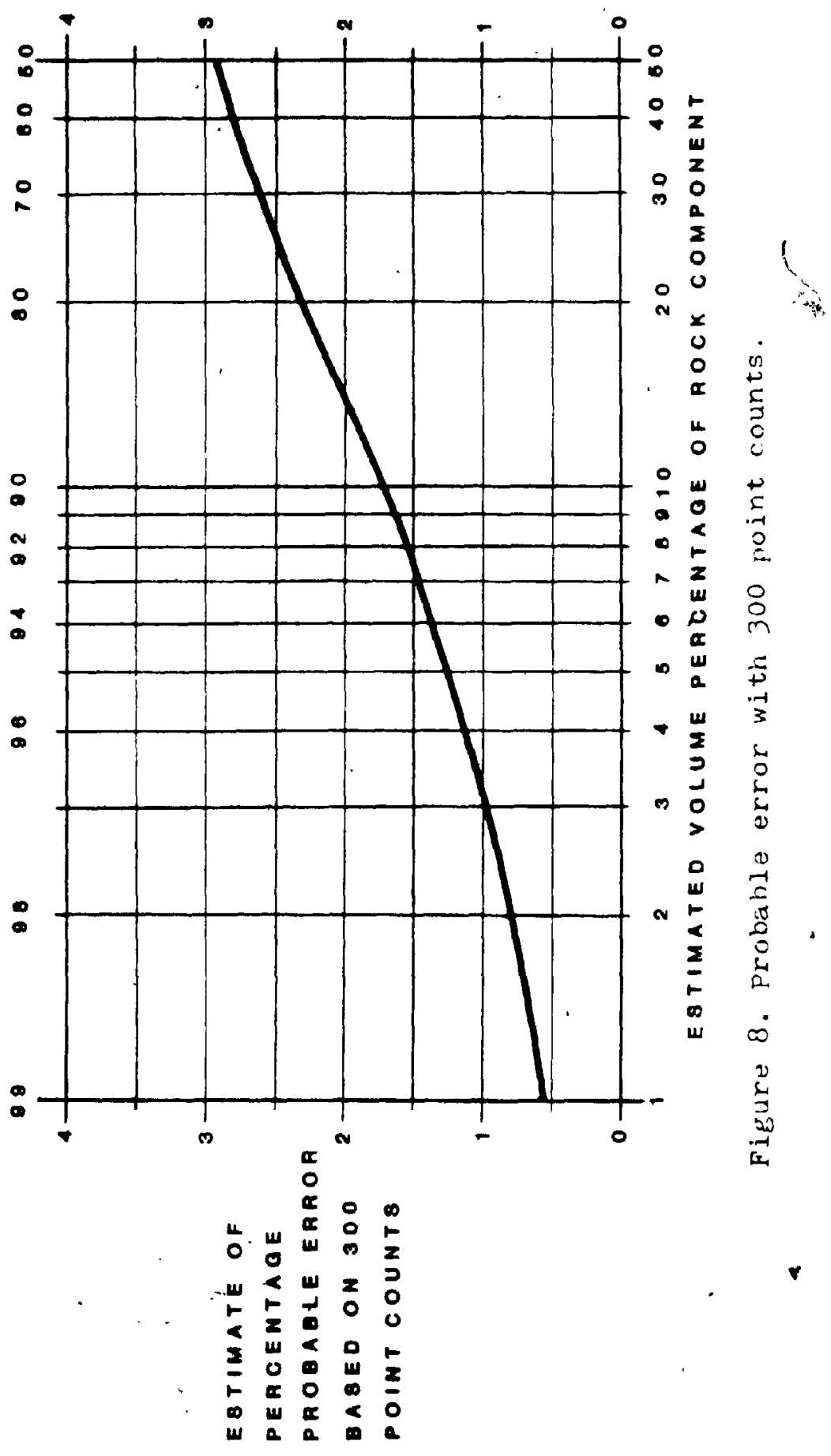


thorough sorting (.75 standard deviation and greater) had a minimum of 75 grains measured. Fifty grain measuremerts were considered sufficient in most of thè samples studied since a study of variance of the $50 \mathrm{grain}$ count mean frón a true mean (200 measurements) versus the degree of sorting (Figure 9) shows an error range generally less than 10 percent at the 95 percent confidence level. This level of accuracy obtained from a minimum of 50 grain counts translates into $\pm .02 \mathrm{~mm}$. for most of the samples studied.

\subsection{Sandstone Petrography}

\subsubsection{Framework Composition}

Percentages of the main detrital constituents of the sands are presented in Table 1. Quartz content (monocrystalline and metamorphic quartz) ranges from 78.2 to virtually 100 percent with an arithmetic mean of 96.1 percent for the 49 selected thin sections. Both dark and light coloured chert grains are present throughout the Parsans Group section, in quantities up to 16.9 percent. Feldspars are infrequently present in more than trace quantities, but locally exceed 5 percent. Accessory minerals such as zircon, and less commonly tourmaline and sphene, are usualty present in minor amounts. Other minor detrital constituents include shale and siltstone grains, mafic rock fragments and woody particles. Using the sandstone classification scheme of Folk (1968) the rocks studied are mainly quartz. arenites with winor sublitharenites and subarkoses (Figure 10). 


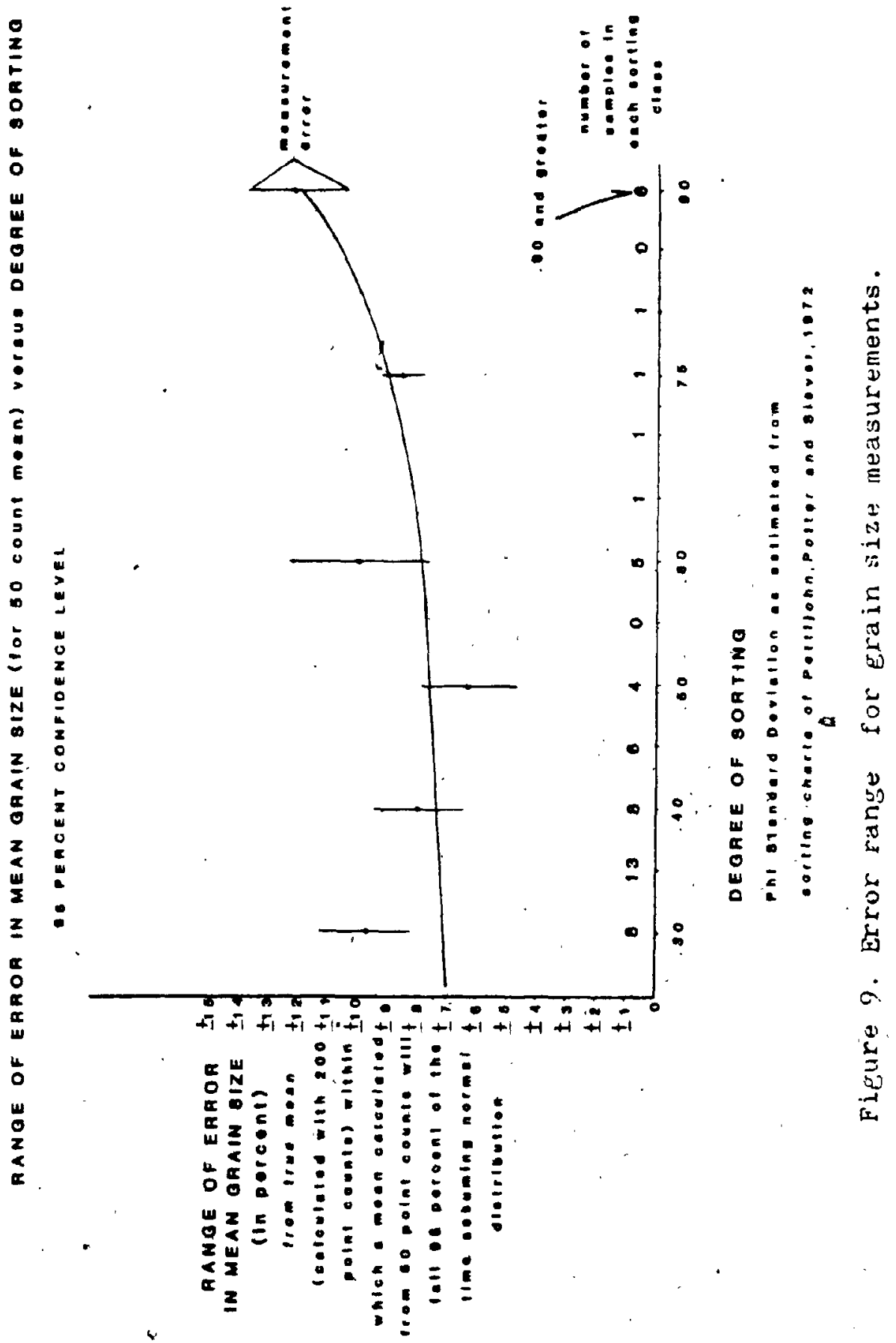


-

$\underline{\dot{x}}$

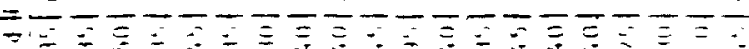

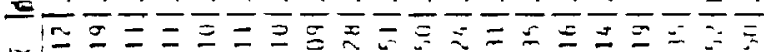

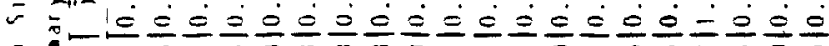

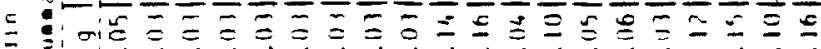

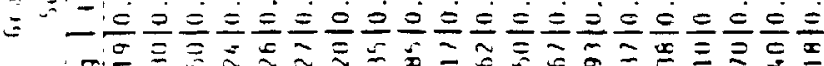

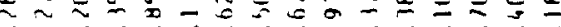

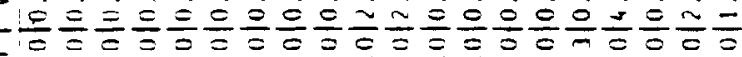

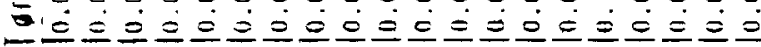

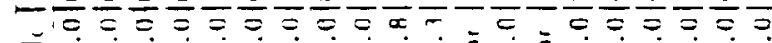
z-

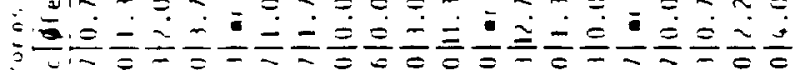

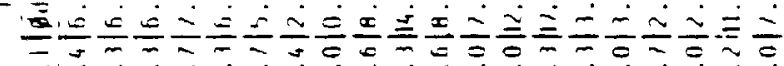

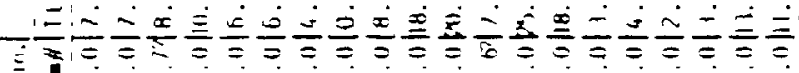

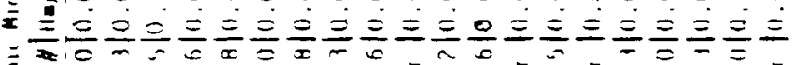

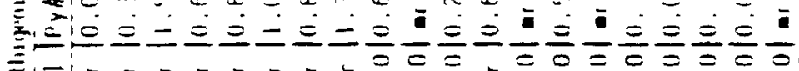

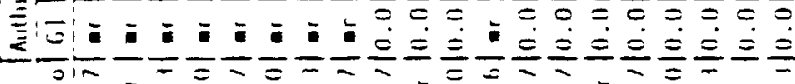

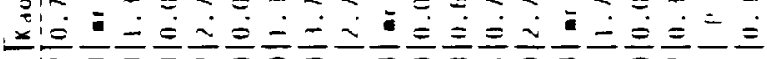

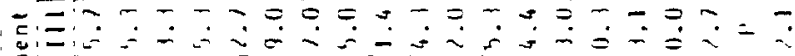

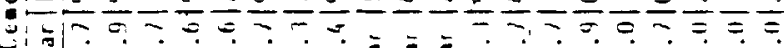

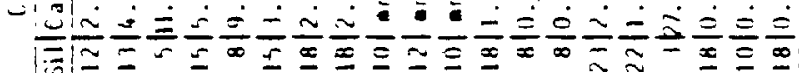

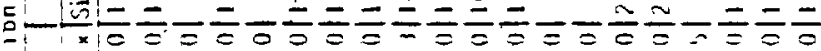

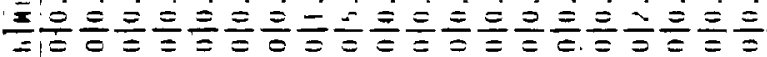

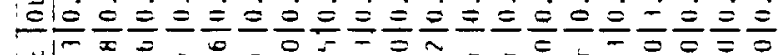

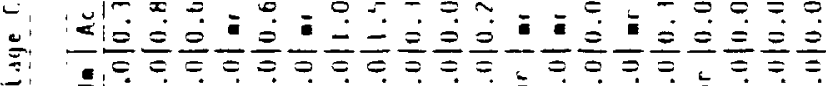

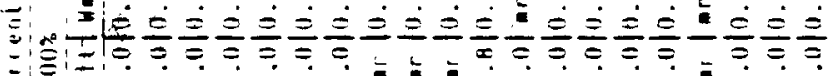

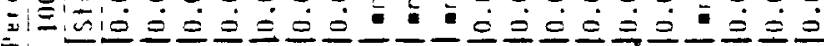
i

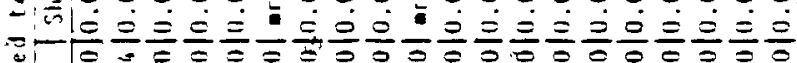

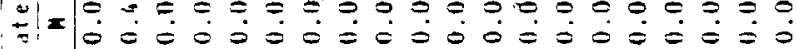

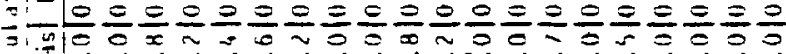

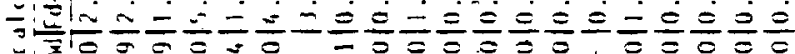
\& $\dot{0} \dot{0} \dot{0} \dot{0} \dot{0} \dot{0} \dot{0} \dot{0} \dot{0} \dot{0} \dot{0} \dot{0} \dot{0} \dot{0}$ 10 응

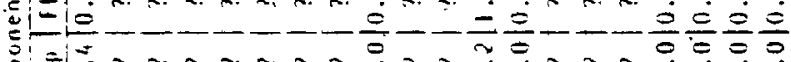

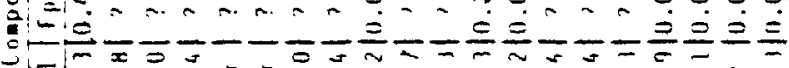
三

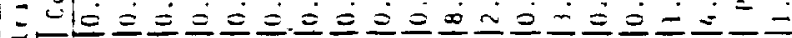
政

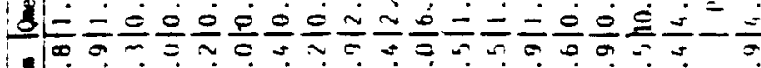

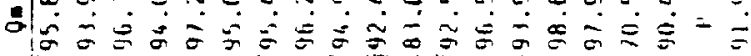

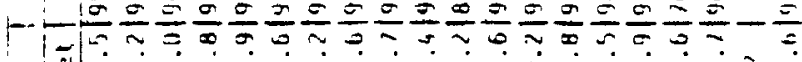

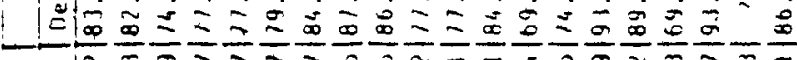

$= \pm 40$

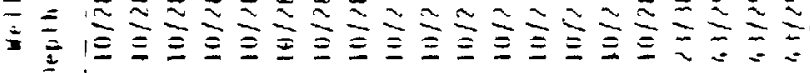

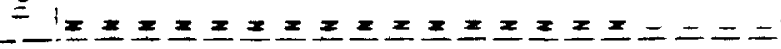

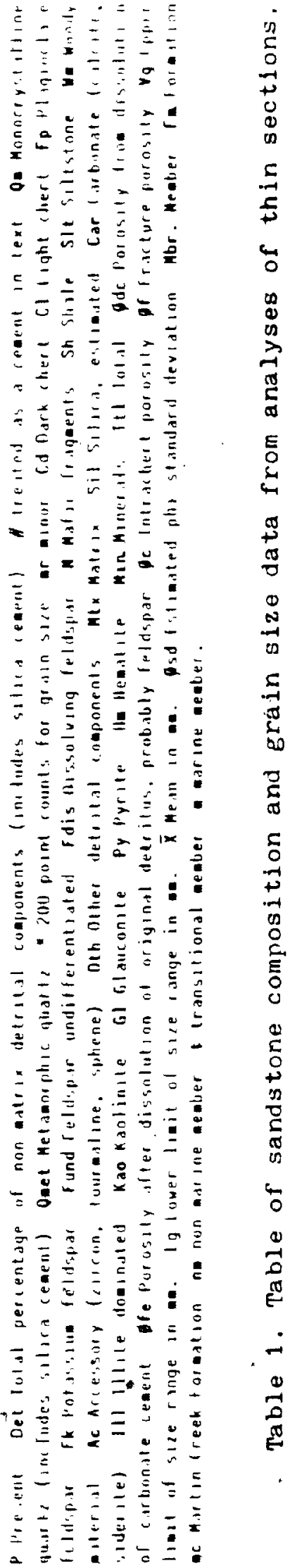




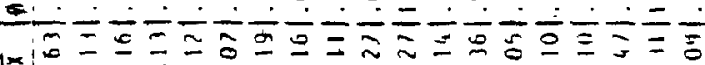

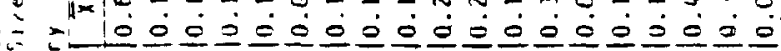
-

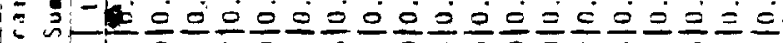

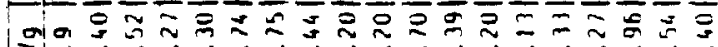
$\rightarrow$

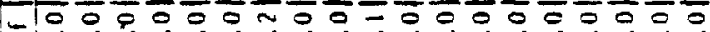

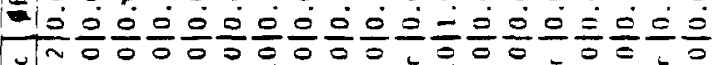

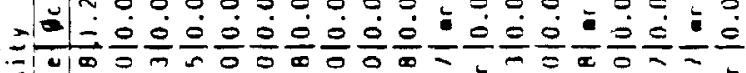

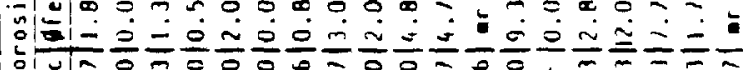
- $\dot{3} \dot{0} \dot{0} \dot{0} \dot{0} \dot{0} \dot{0} \dot{0} \dot{0} \dot{0} \dot{0} \dot{0} \dot{0} \dot{0} \dot{0}=$

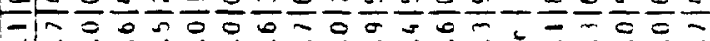

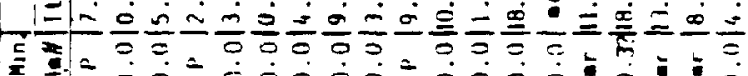
의

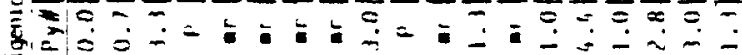
三人口

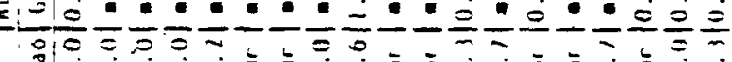

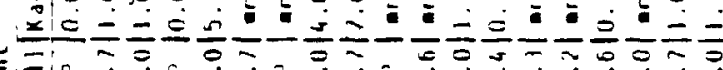
É

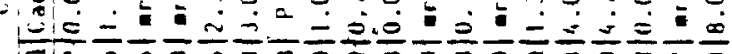

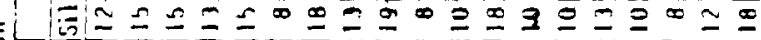

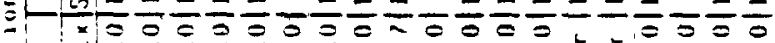

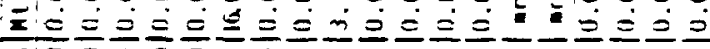

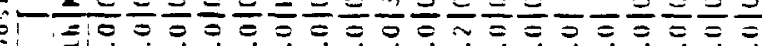

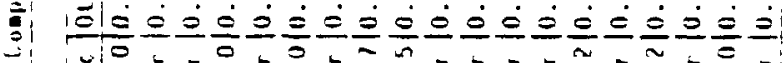

䒠 ज!

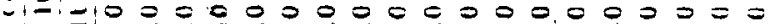

- 2 2

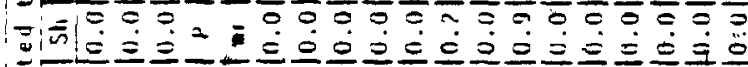

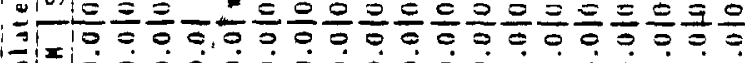

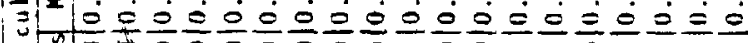

急

|

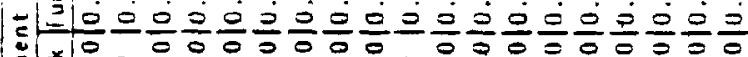

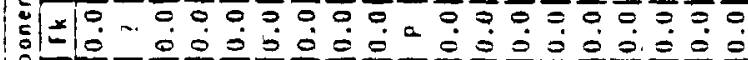

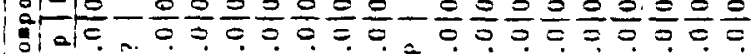

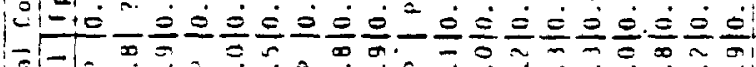

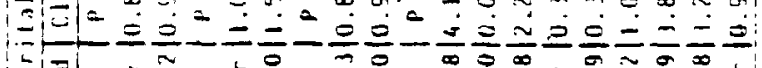

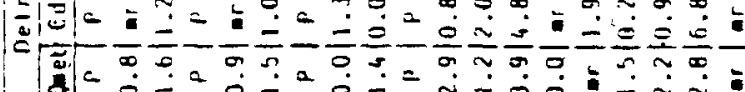

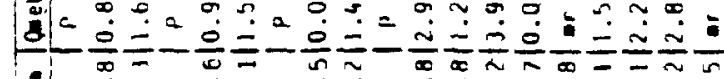

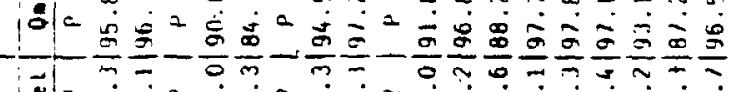

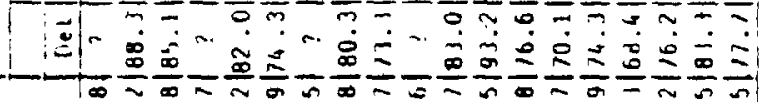

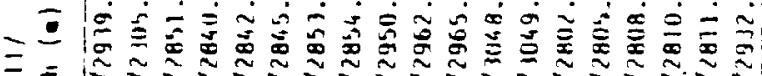

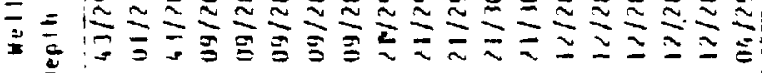
므:-

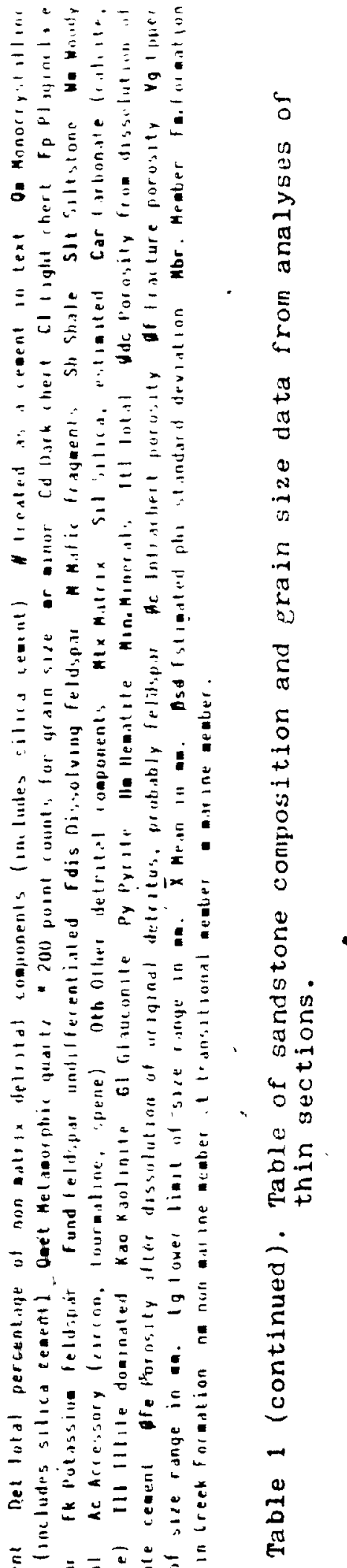




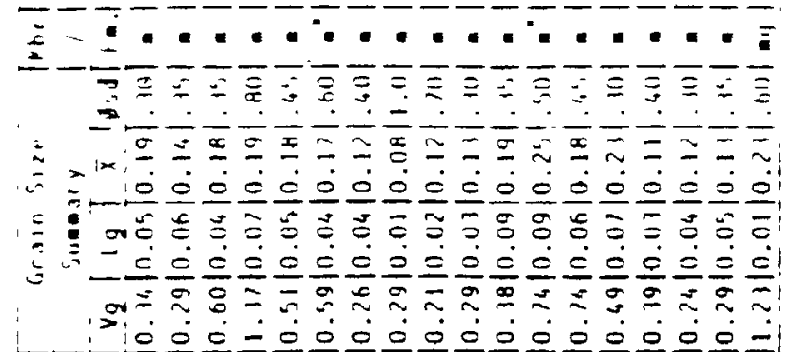

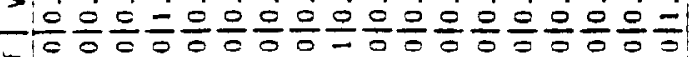

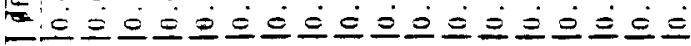

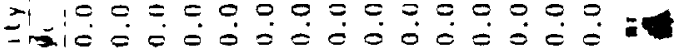

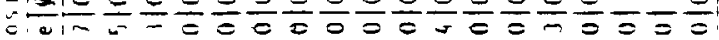

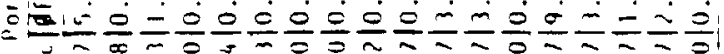

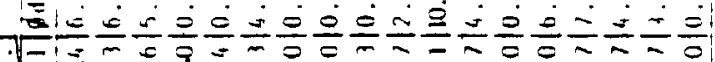

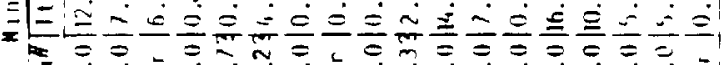

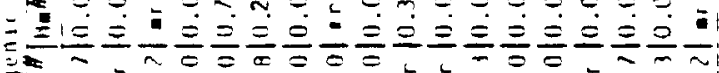

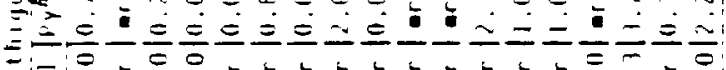

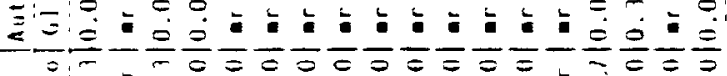

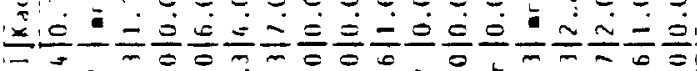

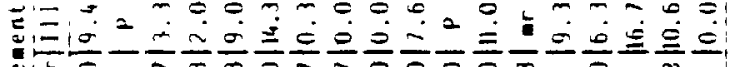

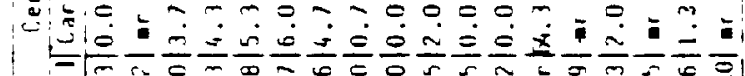
-

-

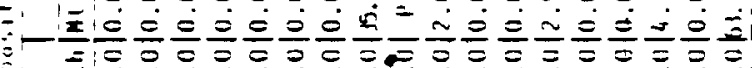

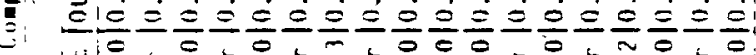

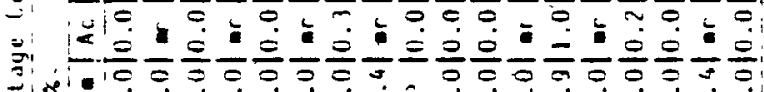

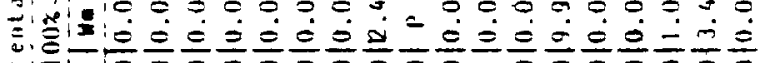

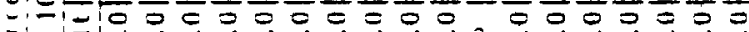

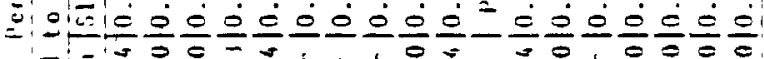

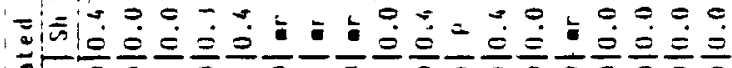

可保前

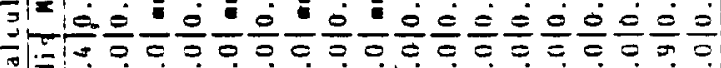

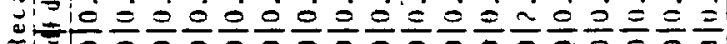

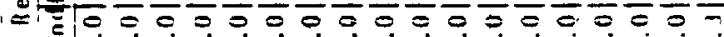

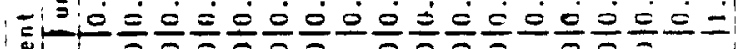

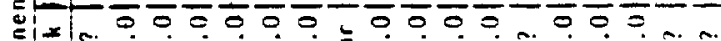

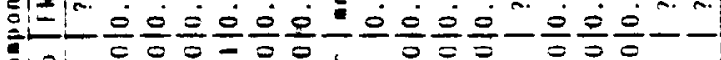

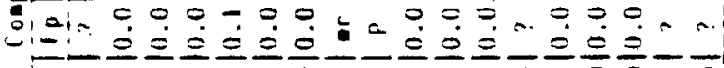

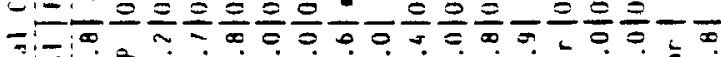

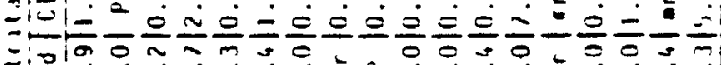

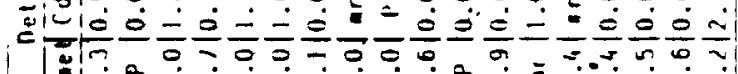

하년

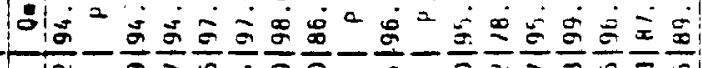

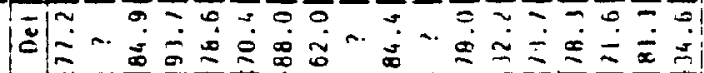

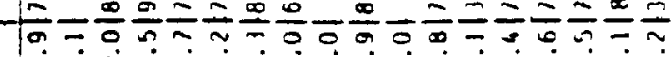

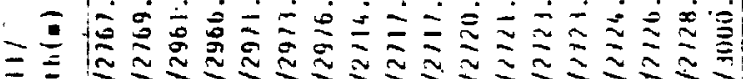

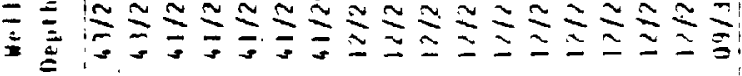

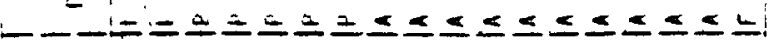

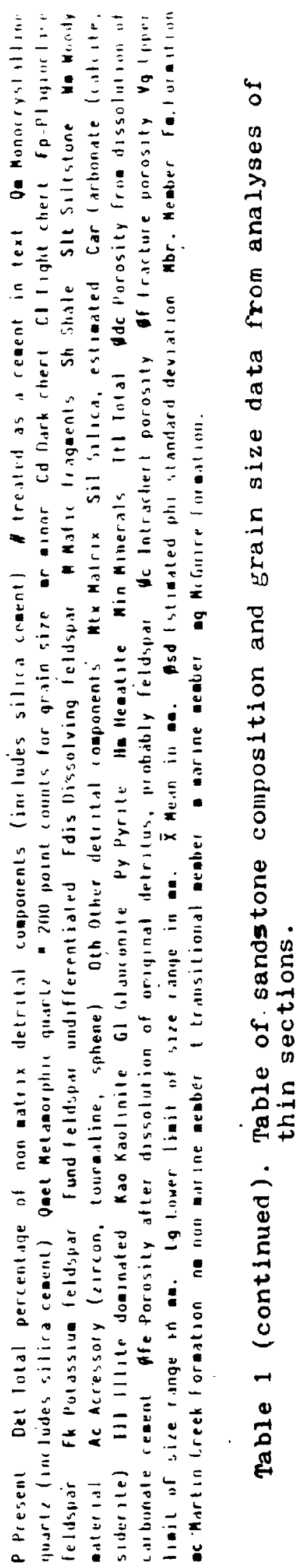




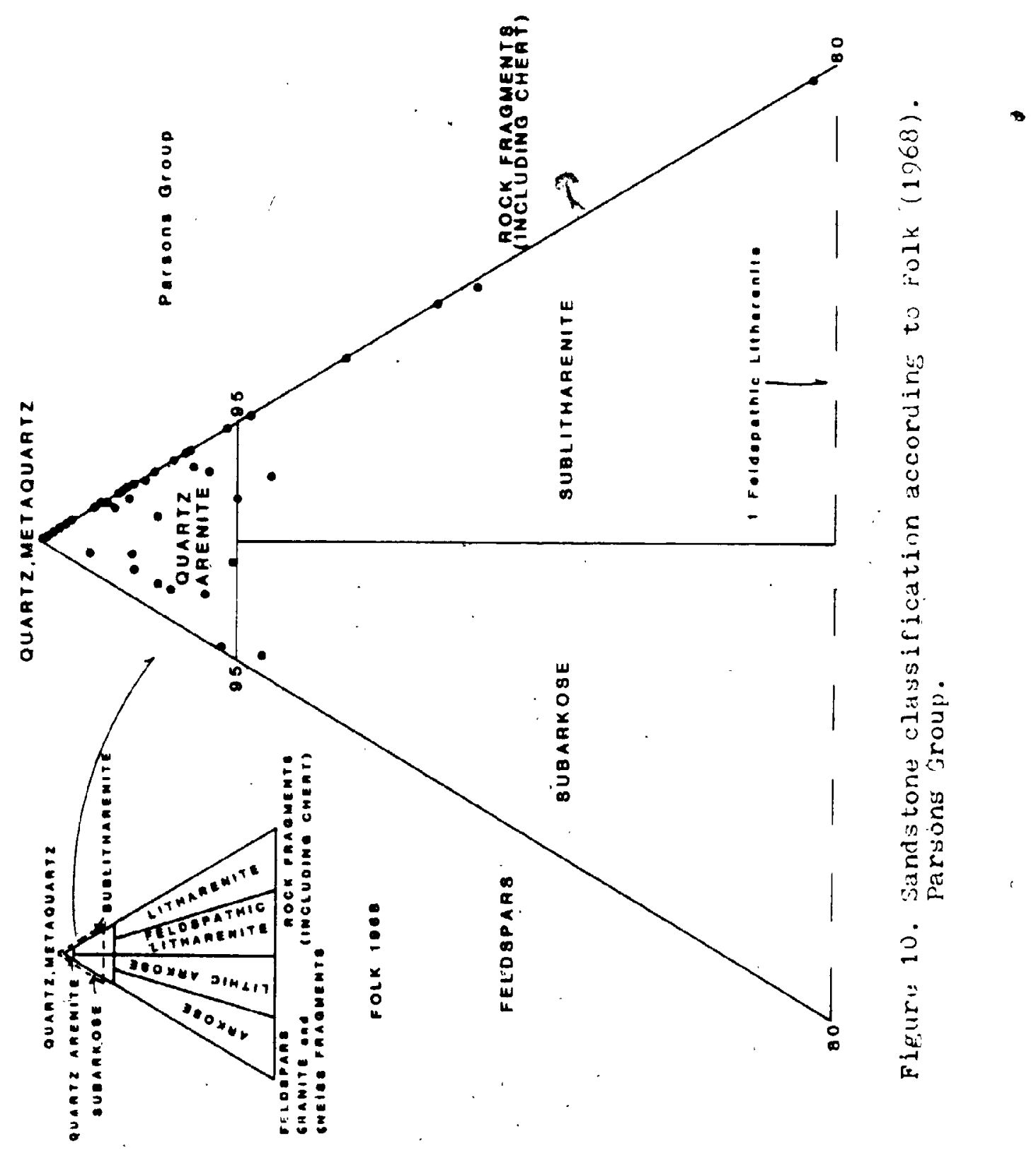




\subsubsection{Quartz}

Three types of quartz were recognized if the petrographic study.

Monocrystalline quartz is an ubiquitous mineral ranging from 70.5 to 99.5 percent of the detrital constituents, averaging 94.3 percent. These percentages include the syntaxial silica cement as framework grains, since the lack of evidence for original internal grain outlines precludes any possibility of quantitatively distinguishing between detrital and authigenic overgrowth silica. Commonly, the monocrystalline quartz contains fluid inclusions and less commonly microlites. The degree of undulose extinction varies widely, even within a single thin section, suggesting variable provenances for these detrital quartz conseituents. The next most abundant type of quartz is commonly polycrystalline, schistose, exhibiting strongly undulose extinction, and intragrain sutured contacts; it sometimes contains aligned micas. Such quartz, interpreted as metamorphic in orlgin, makes up to 10 percent of the detrital grains, averaging 1.8 percent.

Sedimentary quartz is identified, in this thesis by evidence of sedimentary re-cycling. Abraded overgrowths are the most reliable criteria for recognizing quartz of sedimentary provenance. In the arenties studied, diagenetic alteration by quartz and carbonate cements makes certain identification of such evidence near-impossible. The shale-dominated McGuire Formation (Plate 6a) was found in one thin section to contain 
appreciable amounts of sedimentary quartz as a detrital constituent based on the presence of rounded and sometimes multiple overgrowths. Also, Place $6 a$ shows an overgrown broken round quartz clast attesting to recycling. The high degree of rounding of quartz clasts in the McGuire mudstone as well suggests recycling. Together with the presence of rounded zircon in most sandstones these data suggest that recycled sediments are a common constituent of most arenites studied.

\subsubsection{Chert}

Detrital chert fragments are, after quartz, the most common detrital constituent. Both light and dark-coloured chert grains occur throughout the stratigraphic section. The chert commonly contains visible sedimentary relict textures and minerals such as dolomite rhumbs (Plate 6b), euhedral pyrite, voidfilling quartz, fossil; pellet ghosts (Plate 6c) oolitic ghosts and sometimes unaltered calcite. Partial dissolution of the cherty grains is not uncommon'- a result of removal of remant carbonate, expressed as intrachert moldtc porosity (Plate.6d, see also Plate 6d).

The light-coloured chert is usually colourless and less commonly light yellow or green. Textures range frum uniform microcrystalline to a combination of microquartz and megaquartz containing abundant relict textures. The light coloured chert constitutes Erom 0 to 15.9 percent of the detrital grains, averaging 1.5 percent.

The dark-coloured chert is light brown to dark brown, 
sometimes varicoloured, and more rärely hematite-stained. Textures range from uniform microcrystalline (less common than in the light-coloured chert) to a combination of microquartz and megaquartz and a hybrid type of chert exhibiting chalcedonic textures. The dark coloured chert constitutesio to 8.5 percent of the detrital grains, averaging 1.1 percent.

\subsubsection{Feldspars}

The relative quantities of potassic and plagioclase feldspar types were not computed becase of time considerations. Dissolution of feldspar is very common.(Plate 6e), and the distinction between stable and corroded feldspars was made. Limited observations suggest that both the potassic and plagioclase feldspars are susceptible to dissolution.

\subsubsection{Accessory Einerals}

Well-rounded zircon is the most abundant accessory mineral, locally uccurring in measurable quantities, but usually recognizable only as a trace constituent. Tourmaline and sphene are also present locally in trace amounts.

\subsubsection{Minor rock fragments}

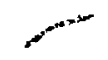

Shale, siltstone, mafic fragments (and minerals) and possibly minor detrital carbonate occur sporadically within the spectmens studied usually only in trace quantities. Woody particles and associated carbonaceous material is present in quanticies up to 12.4 percent. 


\subsection{Compositional Difference Among Stratigraphic Units}

The stratigraphic distinction between the Martin Creek and the Kam ik Formation sandstones as well as units within the Kamik Formation is supported by the compositional variations, despite the high degree of mineralogical maturity of the sandstones studied. As Figures $11,12,13$ and 14 show, quartz, feldspar and rock fragments (chert) proportions are different for each member in the Kamik Formation and for the Martin Creek Formation, as compared with the Kamik as a whole.

Sandstones of the Martin Creek Formation (Figure 11) are typically more feldspar-rich than those of any other parsons Group unit. The average feldspar content in the Martin Creek sandstones is 3.1 percent while the non-marine member of the Kamik Formation averages less than 0.5 percent feldspar as a detrital component (Figure 12). The transitional and marine members contain only trace quantities of detrital feldspar (Figures 13 and 14).

Figures 12,13 , and 14 also indicate that the non-marine and transitional members of the kamik Formation have a higher chert (rock fragment) content than the overlying marine member.

Figure 15 is a triangular plot (from Folk, 1968) for sandstones from Figures 11 to 14 with mean grain sizes between 0.10 and $0.20 \mathrm{~mm}$. Inclusive. Figure 15 shows little variation in 


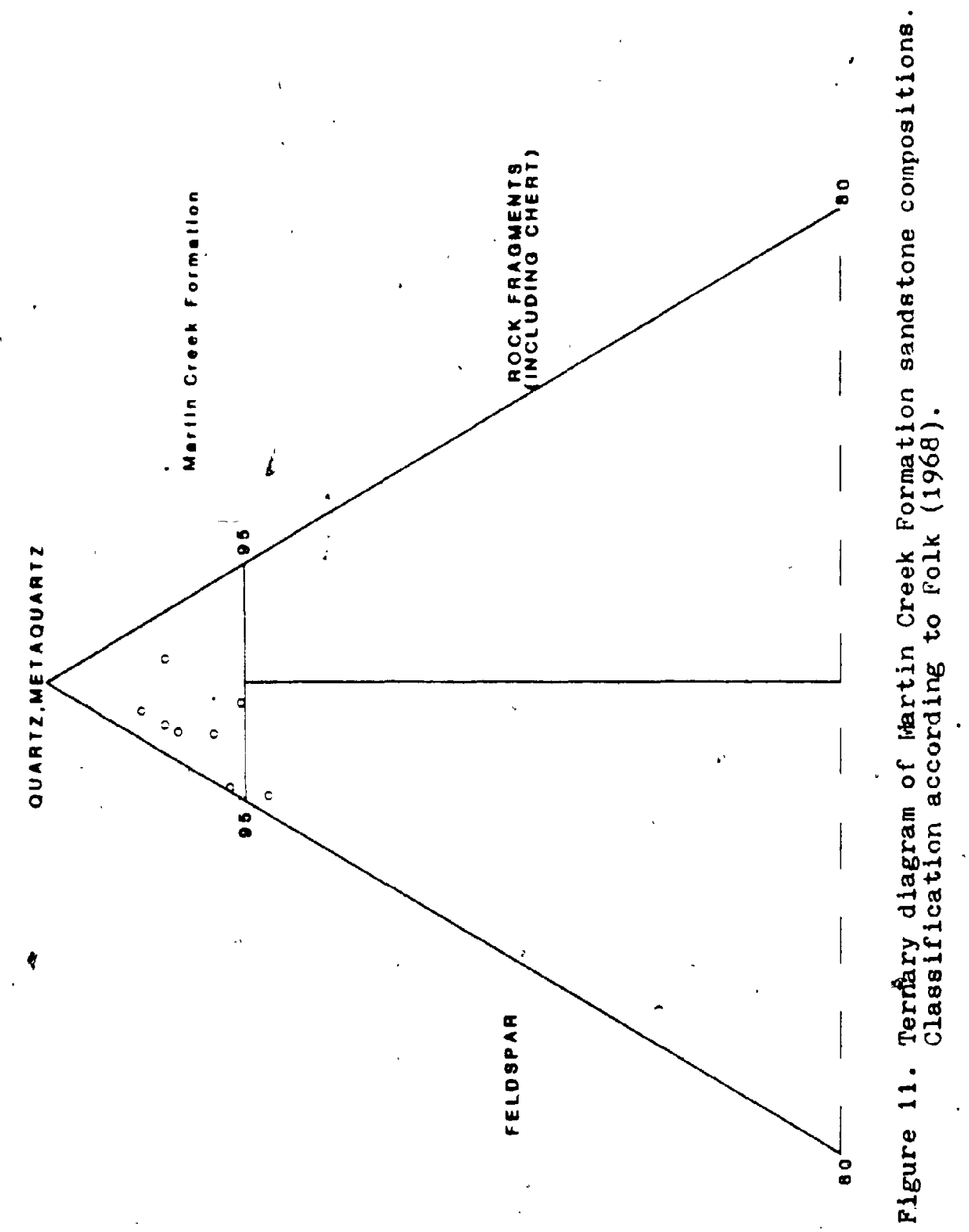



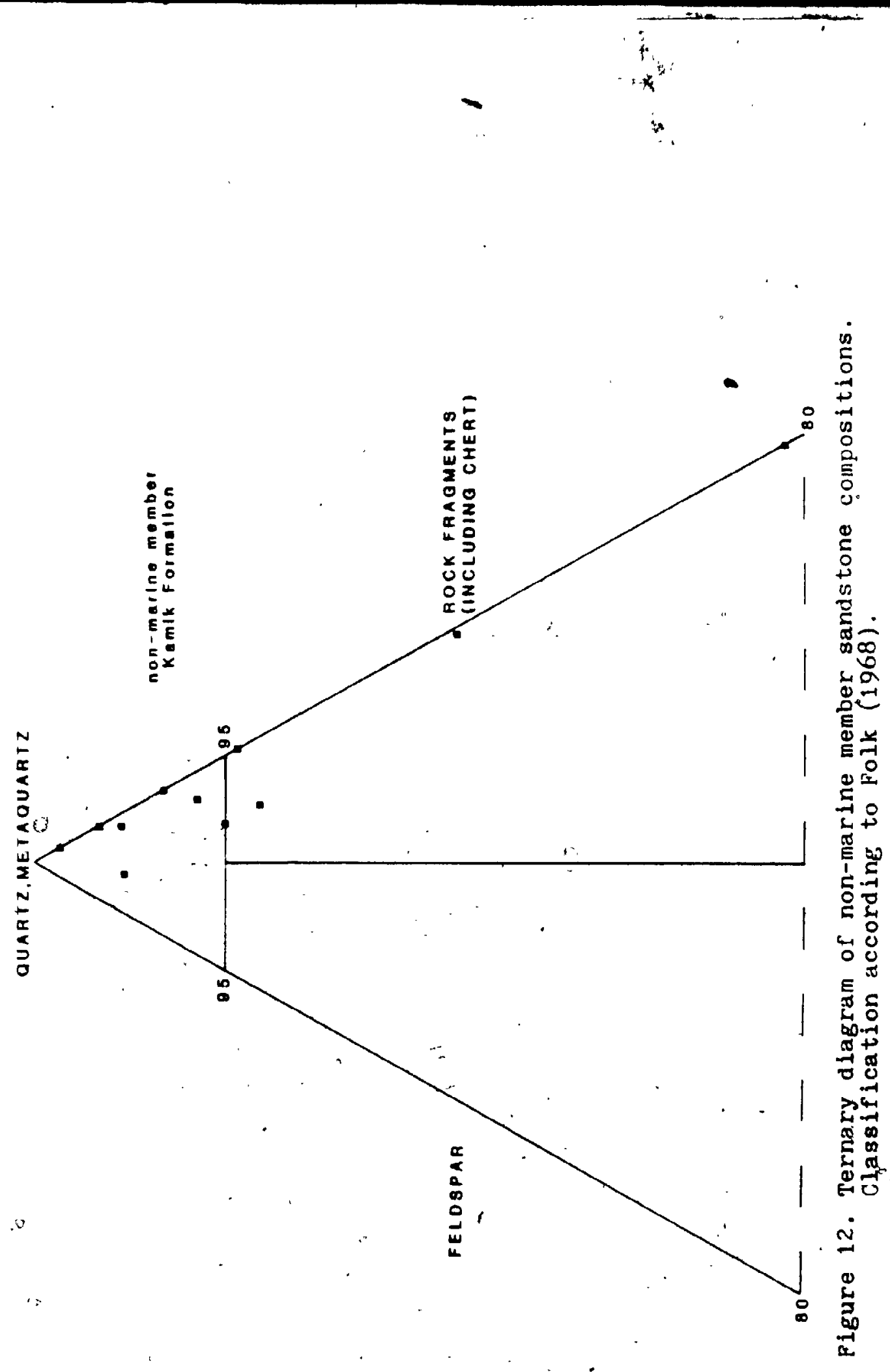

$a$ 


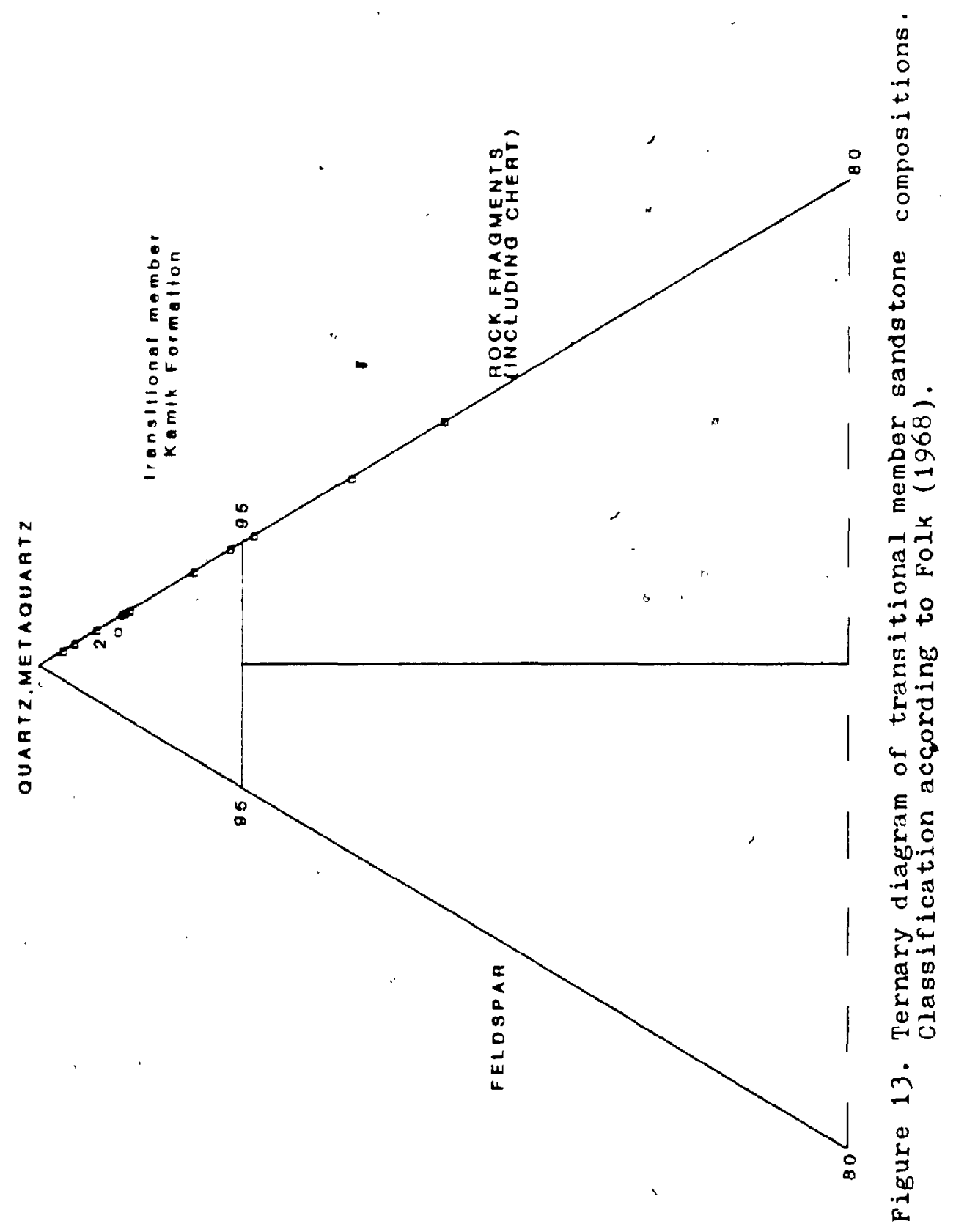




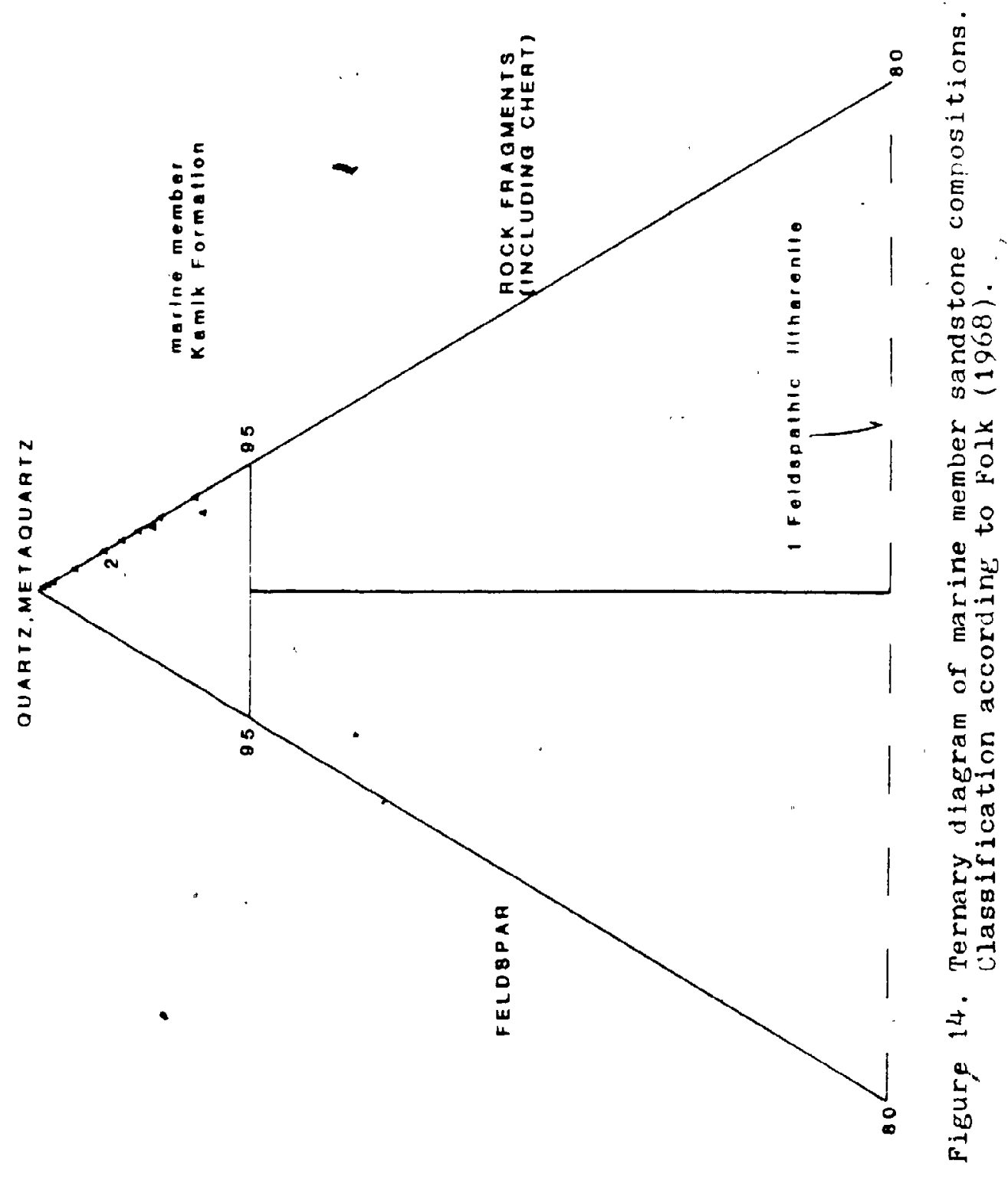




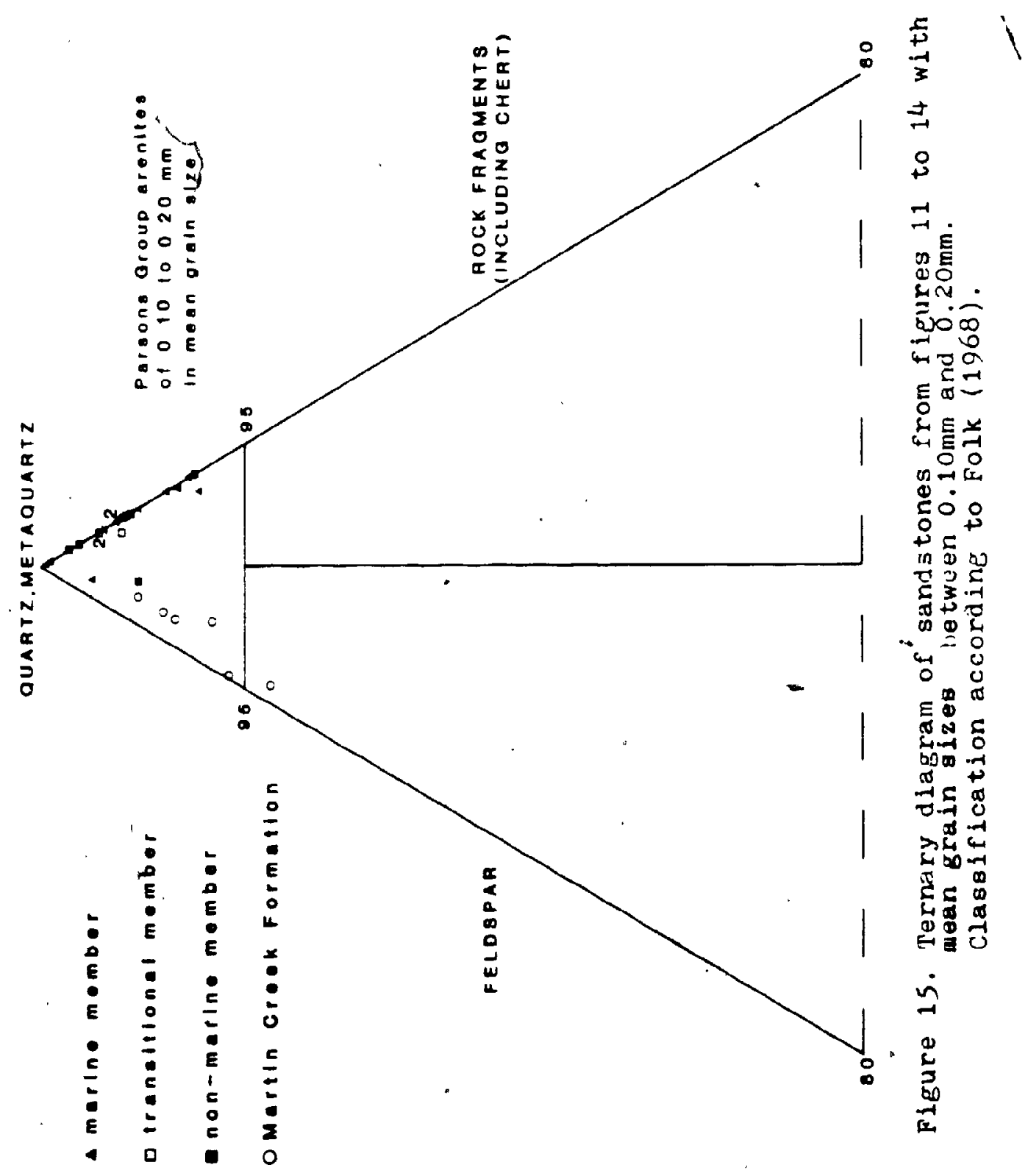


chert content for the three members of the Kamik Formation (certainly between the transitional and marine member at least). The differences in chert content seen in Figures 12,13 and 14 are a function of grain size, the coarser sandstones being more chert-rich. The feldspar variation is still recognizable in Figure 15.

Dissolution of feldspar has most likely caused an under-. estimation of this component. Assuming that the uneven, moldic porosity (oversized pores) recognized in the sandstones is the result of the breakdown of detrital feldspar (observations support this), then the data can, be re-plotted with this porosity type included with identified detrital feldspar. Figure 16 is such a plot and probably more closely resembles original composition. While Martin Creek sandstones still appear to be compositionally unique, the differences between these and other sandstones are not as great as before the feldspar correction. Such a porosity correction is probably a minimum value for feldspar since the secondary moldic porosity may have been partially destroyed by authigenic clays, cements, and late compaction.

\subsection{Textural Differences ':}

Accurate determination of the degree of rounding and sphericity was not possible because of the difficulty in determining original grain outline. Based on a few original grain outlines recognizable in almost every thin section studied (Plate $6 f$ ), the sandstones are estimated to have roundness values (based on 


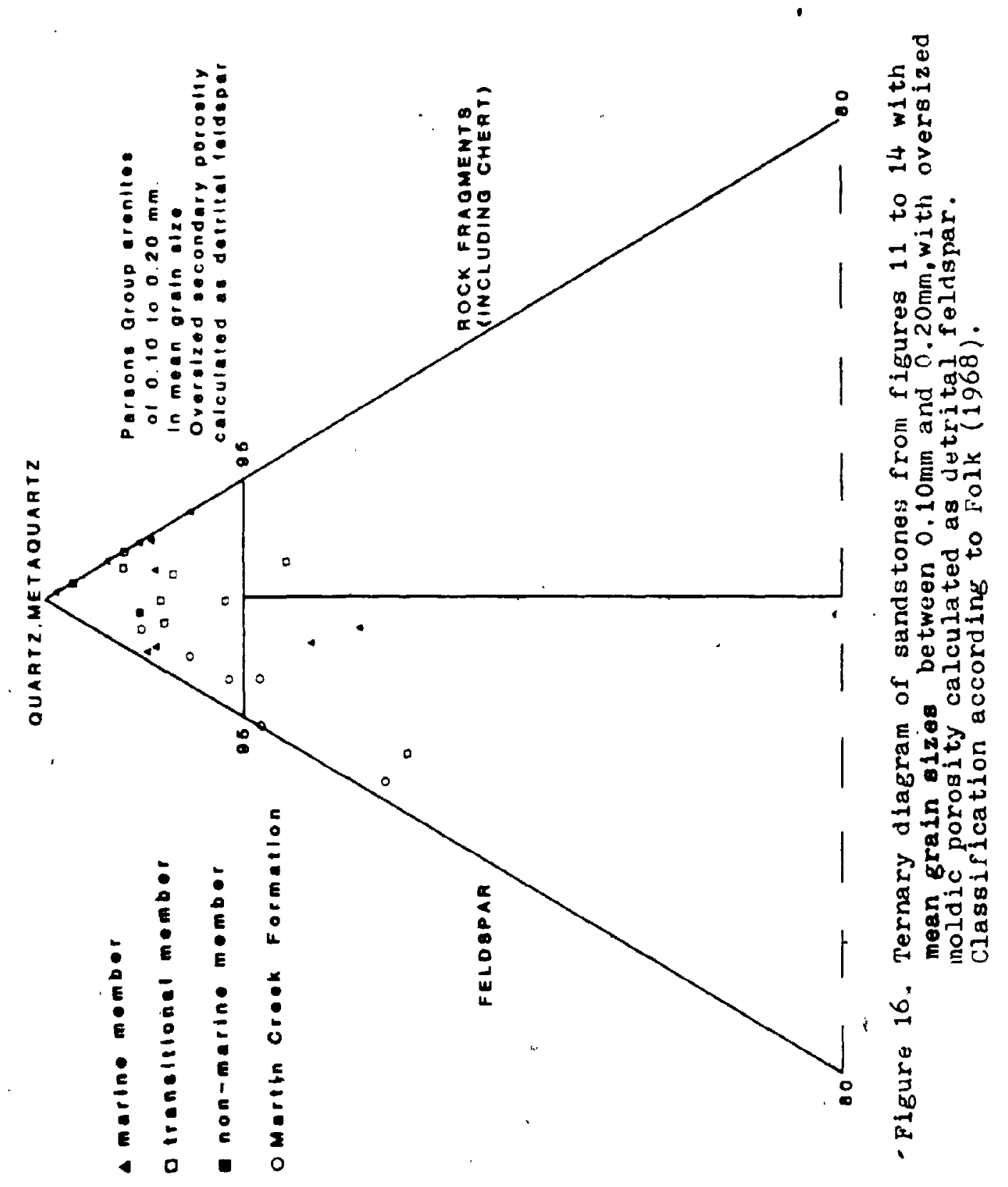


Powers, i953) ranging from 0.4 to 0.85 (subrounded to very rounded Plate 68). Sphericity is estimated to be generally moderate, but ranges from low to high in the specimens studied.

Sorting values were estlmated using the comparison chart of Pettijohn, Potter and Siever (1972). Based on the verbal classification table of Folk (1959) the specimens studied range from very well-sorted to moderately well-sorted with the majority of sandstones being well-sorted (see Table 1). The marine sandstones of the Martin Creek Formation and marine member of the Kamik"Formation are the best-sorted sandstones while the non-marine and transitional members exhibit, in general, somewhat poorer sorting. According to the criteria of Folk (1975), most of the Parsons Group rocks studied in this thesis are classified as texturally supermature.

Granulometric studies show significant size differences among the stratigraphic units. Figure 17 shows the range of apparent mean grain sizes in thin section for each of the four sandstone- bearing stratigraphic units in the Parsons Group. Although sample selection is far from random, and sample quantity is limited; Figure 17 probably illustrates a real intra-Parsons Grouph variability in grain size. Martin Creek sandstones have a sqall range in size $(0.09-0.12 \mathrm{~mm}$.$) in the$ specimens studied. Since the Martin Creek Formation is a coarsening-up sequence the lower linit of grain size is a function of sample location. What lo noteworthy is the finegrained nature of the coarsest sandstone present in the upper 
20
20
3
2
2
2
0
0
0
0

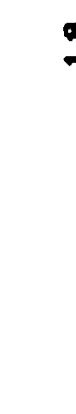

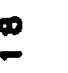

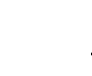

$\infty$

$\infty$

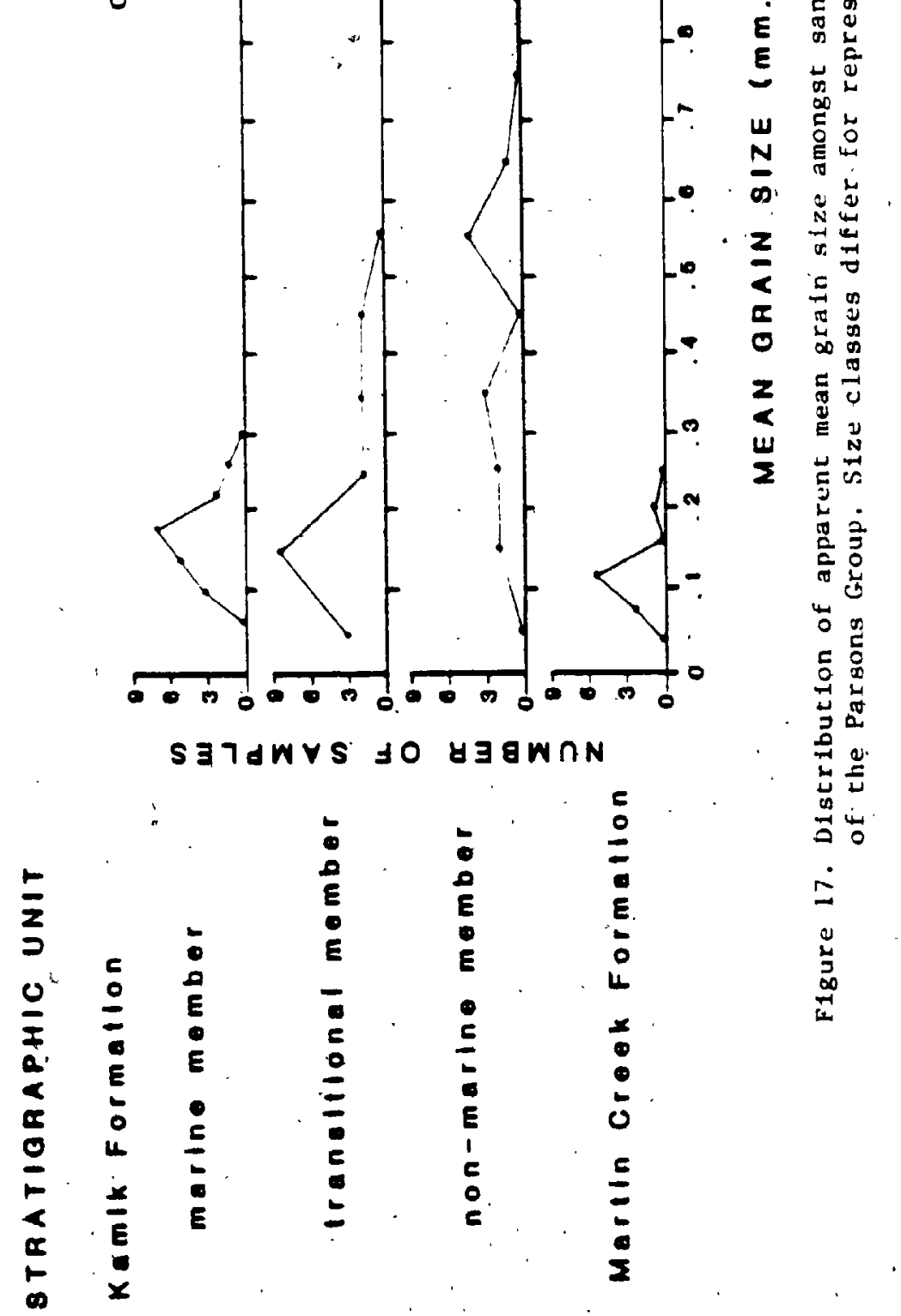

คี

政

证

舟

का

范

菌 
part of the sequence.

The non-marine member of the Kamlk Formation concains the coarsest sands of the Parsons Group. The transitional member is finer-grained and the marine member finer-gralned st 111 (see Figure 17). Such apparent differences in grain size may be attributed to different environments of deposition.

\section{LITHOFACIES, DEPOSITIONAL PATTERNS, AND ENYLRONMENTS OF DEPOSITION}

\subsection{Parson: Group}

The cerm "Parsons Sandstone" was first used by Coté et. al.(1975) for a subsurface sandstone-dominated sequence consisting of the Martin Creek, McGuire, and Kamik Formations. Dixon (1982b,p.14) proposed that the above formations be placed in the Parsons Group. The type locality for the Parsons Group is in well Gulf Mobil Parson F-09, 68058', 34" N., $133^{\circ} 31^{\prime} 33^{\prime \prime}$ W. In the present study the top of the Parsons Group in the F-09 well is set at $2,694 \mathrm{~m}$. $(8,838 \mathrm{feet})$, slightly higher than $2,698.1 \mathrm{~m}$ $(8,852 \mathrm{ft.})$ the depth suggested by both Coté et al. (1975, p. $623)^{\prime}$ and Dixon (1982b, p. 14). The base of the Parsons Group is set, at $3,05,5 \mathrm{~m}(10,024 \mathrm{ft}$.$) , close to the Parsons Group base$ depth of Coté et al. (1975) 10,055 ft.) but significantly different from the 3,081.5. (10,110 ft.) depth proposed by Dixon (1982b). Reasons for thege amendments are discussed in detail in later sections of the text. 


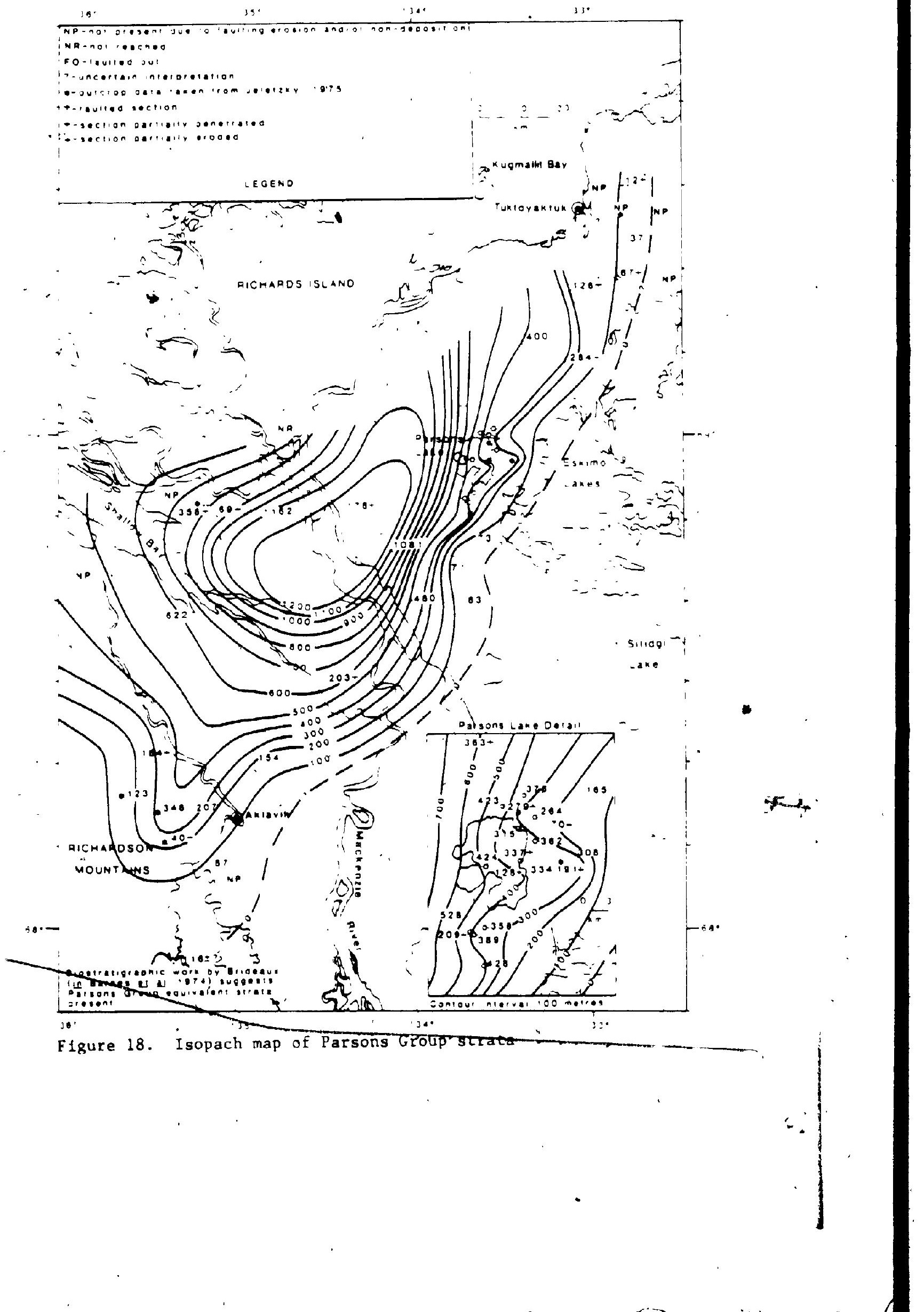


The Parsons Group is present over the inajority of the Mackenzie Delta region. Figure 18 is an interpretive isopach map of the Parsons Group. As with all the isopach maps included in this study, it reconstructs the original depositional thicknesses by estimating original values where partial penetration or removal of section by faulting or erosion has occurred.

A thickness of $1162 \mathrm{~m}$ (3812 ft.) of Parsuns Group rocks $1 \mathrm{l}$ the Kipnik 0-20 well is the maximum penetrated to date. SigniEicant Middle or Late Hauterivian.erosion as well as depositional thinning has occurred just to the notth on the Tununuk High (Figure 6). Deposition to the southeast was cuntrolled by the emergent Eskimo Lakes Arch, near the crest uf which basinward isopach changes are gradual and uniform, succeeded fukther basinward by rapid thickening, suggesting fault-related subsidence. The isopach patterns, although based upon limited information, suggest that the Tuktoyaktuk FaultFlexuré zone (Figure 1) was not the only structural feature affecting Parsons Group deposition. It is more likely that differential subsidence was influenced by a series of down-tothe-basin subsidiary faults. A narrow eastward crending embayment is suggested by isopachs in the Parsons Lake area. This Eeature is recognized in isopachs of both the transitional and marine members of the Kamik Formation (Figures 28 and 31). The anomaly may be related to fauling associated with the Tuktoyaktuk Fault-Flexure Zone,but its near orthogonal trend to the dominant. NNE-SSW structure suggests the influence of a cransverse fault system. Depositional encroachment onto the 
arch was a result of changing water depths and thus depositional environments. The pinchout edge presented for the Parsons Group (Figure 18), approximately coincides with the depositional edge interpreted for the marine member of the Kamik Formation (Figure 31). To the west, limited subsurface information is supplemented by outcrop data from Jeletzky (1975). Parsons strata appear to thin towards the present-day Richardson Mountains, suggesting an influence from an approximately north-south trending "high". This "high" bears spatial and temporal resemblance to the Columbian (Young et al.,1976, p.4), Cache Creek Uplift proposed by Jeletzky (1975). Just to the west of Aklavik, thickening of the Parsons Group suggests an "embayment", which may well be an eastern extension of the Canoe Depression recognized.by Jeletzky (1975). (see Figure 1).

The lack of subsurface information in the northern part of the Mackenzie Delta region prevents reliable definition of Kugmallit Trough, to the northeast. It is likely that it parallels the Eskimo Lakes Arch and ultimately joins up with the contemporaneous Beaufort-Mackenzie Basin to the north (Hea et al , 1980, Figure 17).

\subsection{Husky Formation - Upper Mewer}

Due to the gradational nature and probable depositional continuity of the contact between the upper member of the Husky Formation and the overlying Martin Creek Formation, the upper member is included in this study. The upper part of this unit 


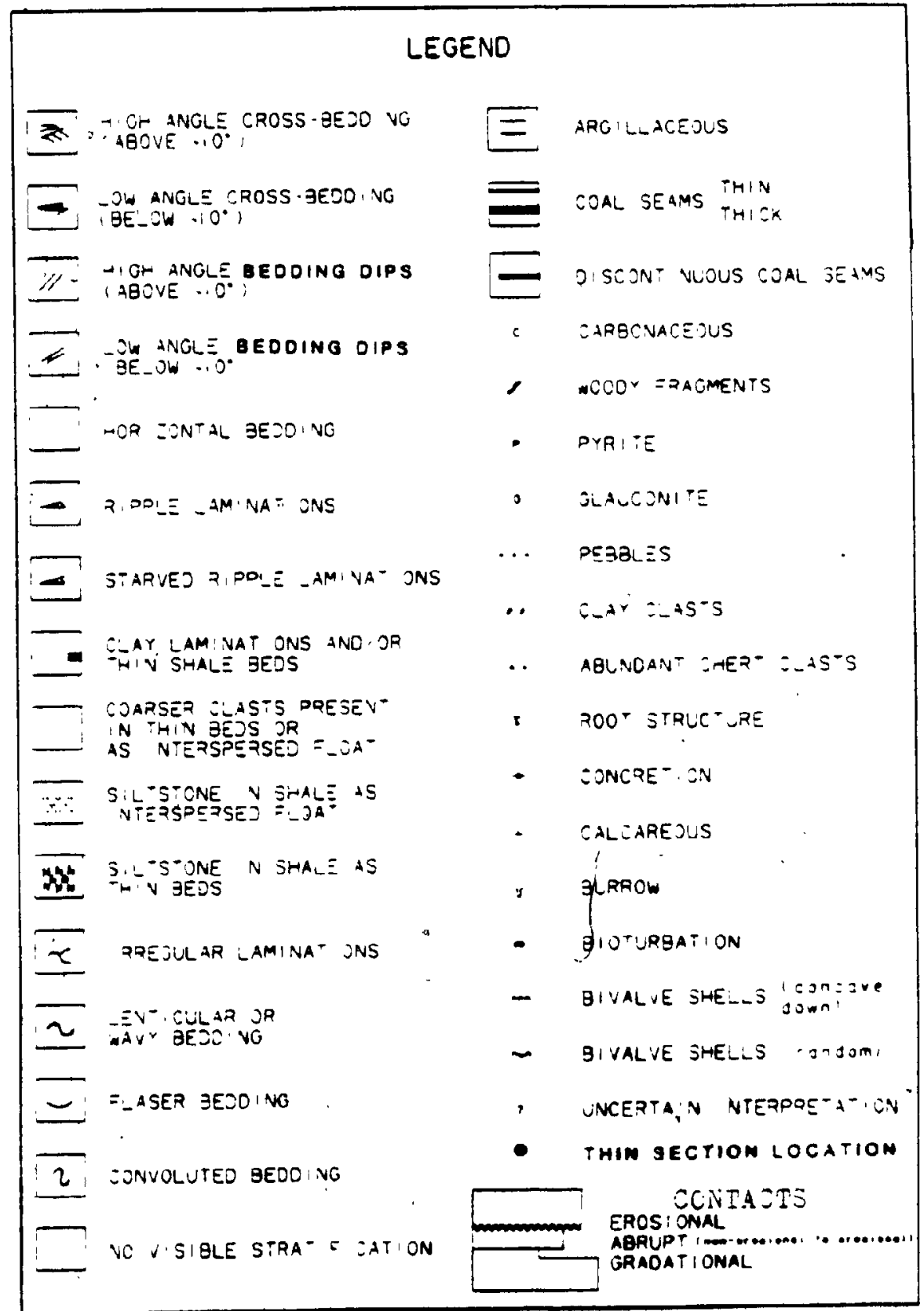

Pigure 19. Legend for graphic display of core. Applies to Figures $20,24,26,27,29,30$ and 41 t to 59 inclusive 


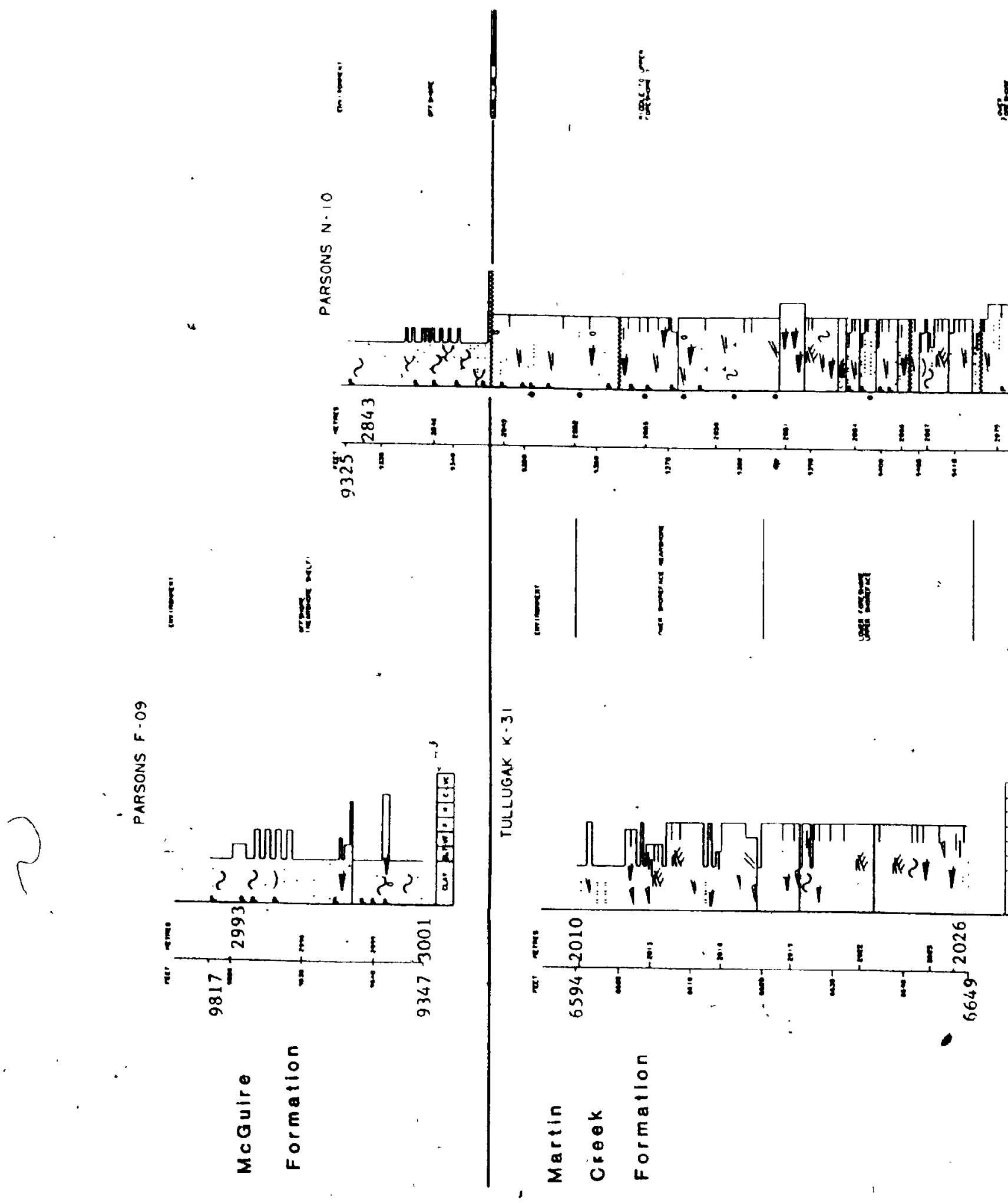




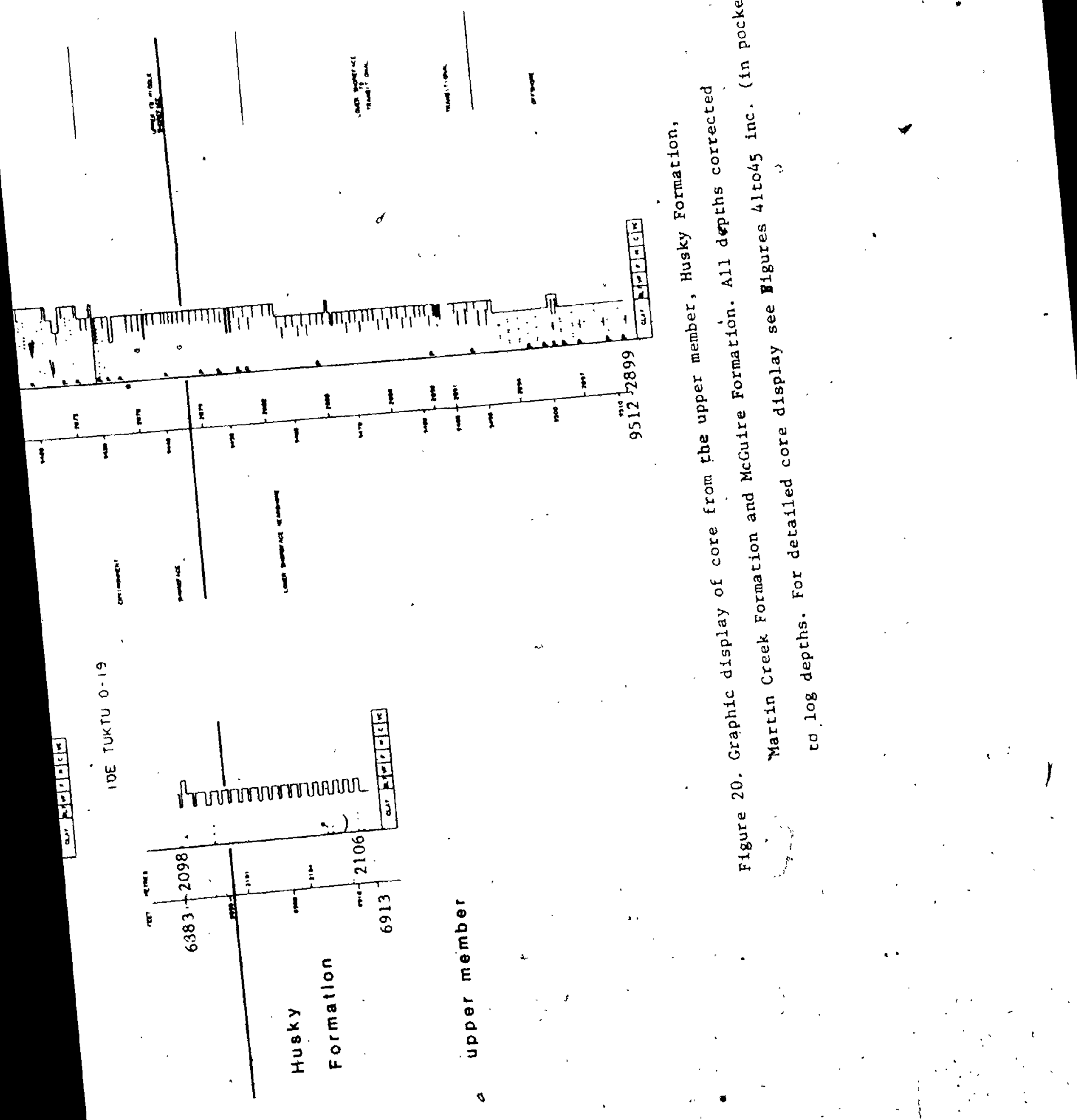


was cored in two wells - Parsuns $\mathrm{N}-10$ and Tuktu $0-19$ (Figures 20 and 41-for legend see Figure 19). Lithology is typically siltstone-dominated with abundant interbedded dark-grey to brownish black shale and very fine-grained sandscone. The rock is characteristically heavily bioturbated with Terebel ina cf. burrows recognizable in the Parsons $\mathrm{N}-10$ well and both " Teichichnus $c f$. and Asterosoma cf. burrows recognizable in the Tuktu 0-19 core. The rock cored in both wells exhibits a general coarsening-up trend easily recognizable from the well logs. The core cuts across the proposed contact between the upper member of the Husky Formation and the overlying Martin Creek Formation in both wells. Well-log response allows easy recognition of this contact, but actual lithologies change little.

In the Tuktu 0-19 well, slight upward coarsening of the strata occurs just above the base of the Martin Creek Formation, while in the Parsons N-10 well, bioturbation decreases in intensity and the strata are less argillaceous at the base of the Martin Creek Formation. As shown in Figure 20, the contact is interpreted as occurring within strata deposited in a middle shoreface environment. It is suggested that this contact between the Husky upper member and Martin Creek Formation, obtained from well logs and used throughout the subsurface, represents an approximate middle shoreface environment of deposition. According to Dixon (1982b), the lower part of the upper member is shale-dominated, with minor siltstone, sandstone and carbonate concretionary beds. The basal contact of the 
upper member is defined $y$ an abrupt contact with the sandstone of the lower member (see Figures 5 and 6).

\subsubsection{Environmental Interpretation}

Lithology and ichnology (environmental interpretations from trace fossils after Chamberlain, 1978) suggest offshore deposition changing upwards into a middle shoreface depositional environment for the Husky upper member. The sparsity of core in the lower part of the upper member prevents any definite interpretation of maximum water depth, but a shelf setting is likely.

\subsection{Martin Creek Formation}

The lower contact of the Martin Creek with the Husky Formation corresponds with the most recognizable gama-ray signature available in this stratigraphic sequence and probably reflects a fundamental, environmentally controlled lithologic change which can be traced throughout the subsurface. Myhr and Young (1975) used this gamma-ray pick in their mapping of the Martin Creek Formation. The upper contact of the Martin. Creek with the McGuire Formation is variable in the subsurface. Within the Kugmallit Trough, the contact is apparenty gradational with the overlying McGuice Formation, and the contact is chosen at the point where shale content increases, sandstone beds thin and the sonic log response changes. Towards the Eskimo Lakes Arch, the upper contact is abrupt and most likely erosional (see Figure 20), an aspect probably typical uf the contact near the Eskimo' Lakes Arch. 
Martin Creek strata have been cored in wells Tuktu $0-19$, Tullugak $K-31$ and Parsons N-10 (Figures 20,42,43 and 44). The 2 metres cored at the base of the Martin Creek Formation in the Tuktu 0-19 well express a slight coarsening-up textural trend. The 31 metres cored through the full thickness of the formation in the Parsons $\mathrm{N}-10$ (Figures 43 and 44) well is dominantly light grey to white, very fine to Eine-grained quartzose sandstone, becorning progressively less argillaceous upwards in the section. Common sedimentary structures are horizontal bedding and. low angle cross-bedding. Numerous reactivation and/or erosional surfaces occur throughout the section. The beds are locally burrowed, commonly pyritiferous and contain abundant zones of concave-down pelecypod shells.

In Tullugak K-31 (Figure 42), the 16 metres of Martin Creek Formation cored represent the only cores of this unit from the Kugmallit Trough. The lower section of the core is typically a light grey to white fine-grained, slightly argillaceous ; quartzose sandstone containing both low and high angle crossbeds and minor ripple cross-lamination. The beds are intermittently bioturbated and Asterosoma cf. burrows were recognized. Generally concave down pelecypod shell zones are common throughout the section. A slightly shalier section overlies this sandstone. This section is moderately to heavily burrowed, containing the burrows of Terebellina cf. and Chondrites sp.. Log response to upper? Martin Creek strata in the Tullugak $k-31$ well shows interbedded shale and sandstone 
beds similar to those in the other Kugmallit Trough wells (Kipnik 0-20, Kugpik 0-13, Unak B-11), suggesting a gradational upper contact with the overlying deeper water McGuire Furnation throughout the Kugmallit Trough (Figure 6).

\subsubsection{Depositional Patterns}

4

Figure 21 is an isopach map of the combined Husky upper member and the Martin Creek Formation. Thickness change is fairly uniform away from the Eskimo Lakes Arch and ints the Kugmallit Trough. The Tununuk High apparently Eormed the notthern flank of the Kugmallit Trough at this time. The thickest section of $404+$ metres for this stratigraphic interval occurs at the Tullugak $K-31$ well, with log relationships indicating a faulted top. Isopachs indicate an opening of the trough towards the west. The Martin Creek Formation isopachs presented in Figure 22 shows the same overall trends as thuse in Figure 21, except for the fallowing:

1. Contours no longer open to the west but either close in the Kugmallit Trough around the thickest section of 161 meters in the Kipnik 0-20 well, or open to the northeast.

2. Subsurface and outcrop tata suggest the existence of the Napoiak High just east of Aklavik as well as the presence of an embayment just west of Aklavik called the Canoe Depression (Jeletzky, 1975). Some influence by the Cache Creek Uplift is also recognizable.

3. Thickness values in and north of the Parsons Lake area may indicate anomalous thinning approximately parallel to the Eskimo 


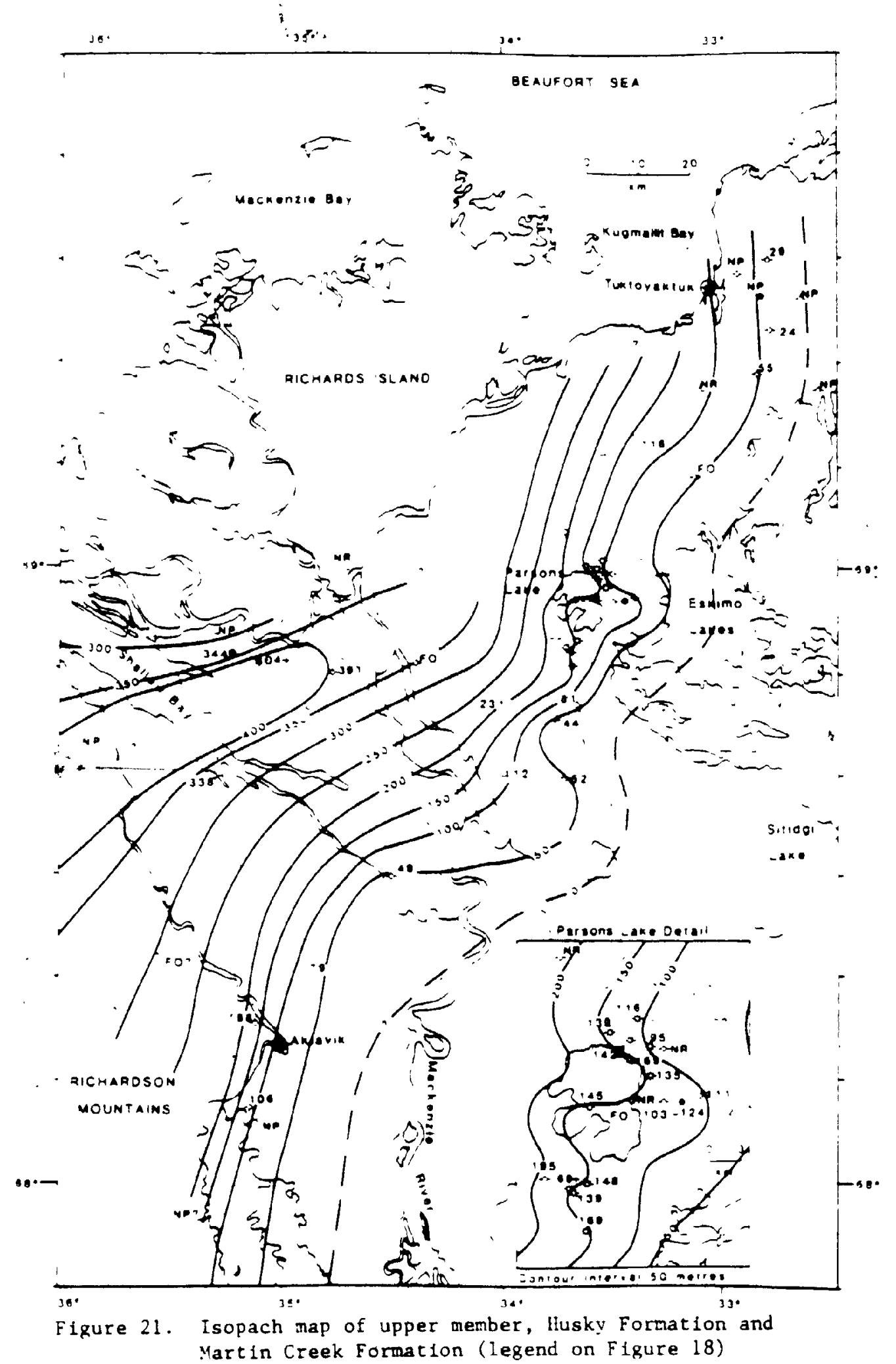




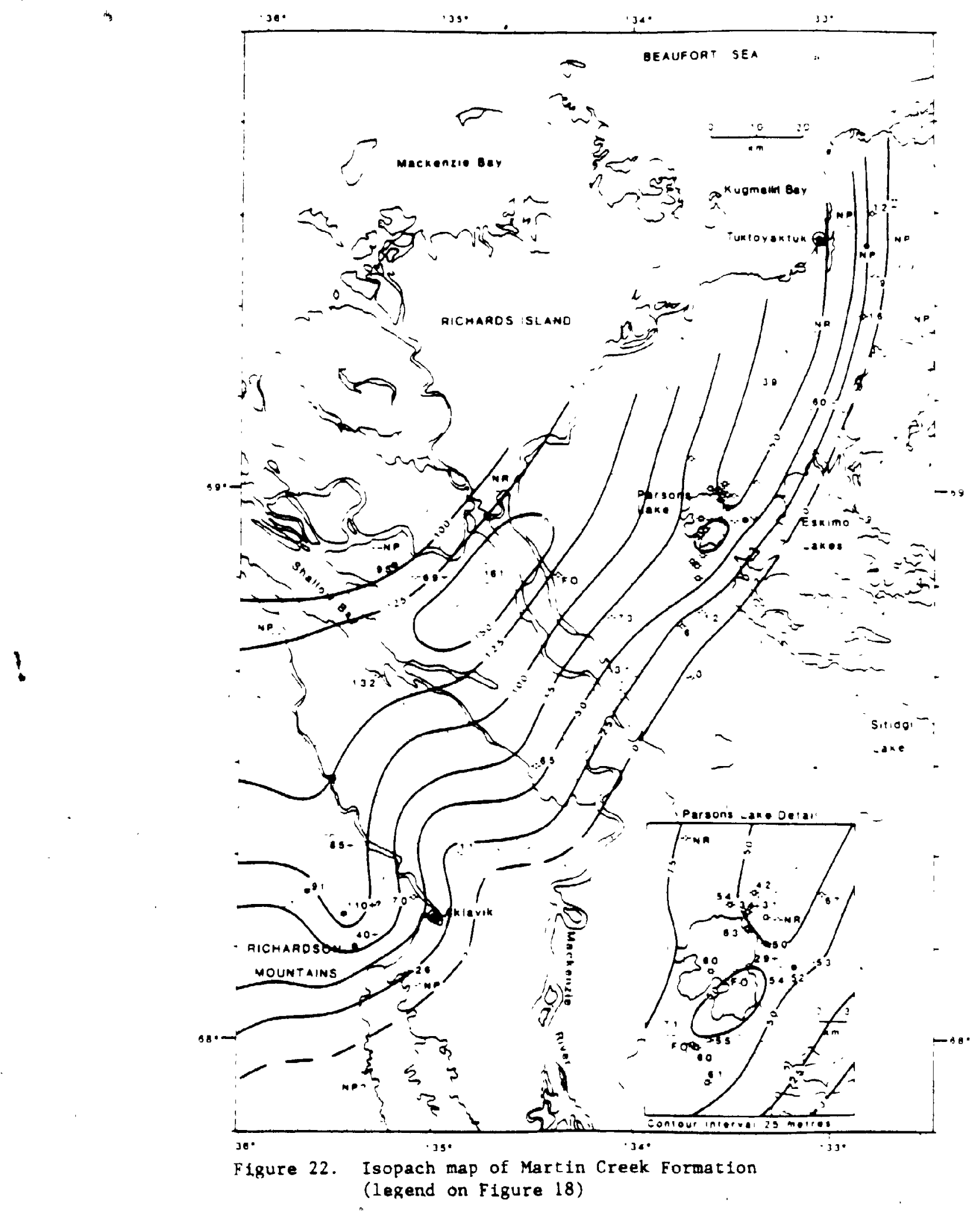



throughou't the $\mathrm{N}-10$ and $\mathrm{K}-31$ cores. Hunter et al. (1979) stated that subhorizontal erosion surfaces probably occur in deposits formed from the slow progradation of most kinds of barred nearshore systems but should not occur. in deposits formed from non-barred prograding shoreline systems.

The gradational contact between the Martin Creek and McGuire Formations apparent in the Kugmallit Trough suggests that the shallower-water facies of the Martin Creek did not excend fully into the depocentre but was halted by transgressing conditions associated with McGuire Formation deposition. Supporting this hypothesis is the northwesterly shale-out trend of Martin Creek strata in the Richardson Mountains suggested by Jeletzky (1975) and Myhr and Young (1975).

The mineralogical and textural maturity of the Martin Creek sands (chapter 4) suggests high wave and/or tidal energy. Dixon (1982b) concluded that the lack of tidal channel - tidal inlet deposits encountered in the subsurface favours microtidal conditions. A high wave energy, environment hypothesis is supported by the dotinance of physical sedimentary structures as opposed ta biogenic sedimentary structures (Elliot in Reading, 1983,p. 152, Heward, 1981, p. 238) and the presence of concave down pelecypod shell zones throughout the Tullugak K-31 and Parsons N-10 cores. Salazar-Jiménez et al. (1982) suggested that concave-down valves in thin zones indicate stabilization under moderate to high-energy conditions, a conclusion reached by numerous authors in previous studies on bivalve orientaton. 
Heward (1981) as well stated that most barrier islands occur on microtidal and mesotidal coasts.

Regressive shorelines, such as interpreted for Martin Creek deposition, are controlled to a large degree by persistently dropping sea level and/or Increased sediment supply conducive to shoaling.

\subsection{McGuire Formation}

As described in the preceding section, the contact between the McGuire Formation and the underlying Martin Creek Formaton can be abrupt suggesting erosion near to the Eskimo Lakes Arch or gradational, as within the Kugmallit Trough. Jeletziky (1980) suggested that McGuire strata may rest on rocks as old as those of the Husky Formation. This relationship is demonstrated by subsurface interpretation in this thesis for the Reindeer P-60 well, where McGuire Formation strata are shown as resting upon the upper member of the Husky Formation. Detailed stratigraphic analysis shows that this relationship is probably a result of Martin Creek non-deposition (see Figure 5).

The upper contact of the McGuire Formation with, the overlying Kamik Formation is usually abrupt and erosional, probably a result of channelling at the base of the kamik. 'However, transitional contacts are recognizable in numerous welis (Parsons $\mathrm{N}-10, \mathrm{~N}-17, \mathrm{~L}-37$, Kamik D-58, F-38, Imnak J-29 and possibly Kugpik $0-13$ and Parson P-41) with the thickest 
transition being $9 m$ in the Parsons $L-37$ well.

McGuire Formation strata were cored in two holes - Parsons F-09 and Parsons $\mathrm{N}-10$ (see Figures 20,44 and 45 ). In the Parsons $\mathrm{N}-10$, well thin pyritic, coarse-grained erosional lag deposits directly overlie the Martin Creek Formation. McGuire Formation lithology is typically black shale with lenticular interbeds of light grey to blue-grey siltstone, commonly pyritic and moderately to heavily bioturbated. The shale is commonly waxy and fissile and is locally kerogenous. The Parsons F-09 section is cypically pyritiferous, biuturbated, thin to lenticularly bedded greyish-brown mudstones, light-coloured siltstones and quartz wackes. The lower part of the core contains thin beds of medium to coarse-grained cross-bedded sandstones. Present here, as well, are zones of chert pebbles and glauconite.

Lithologies interpreted from weîl logs are shale-dominatied. with thin interbeds of mainly coarsening-up sandstone bodites. Coal and carbonaceous shales have been reported from Mouire cuttings in the Kugpik 0-13 well (Canstrat Service Ltd: log number $D-N W T-537$ ) but stratigraphic inţerpretations indicate this carbonaceous material is from the lagoonal and back-bar facies of the underlying Martin Creek Formation.

\subsubsection{Depositional Patterns}

The thickest subsurface McGulre Formation section of 81 . metres occurs in the Kipnik 0-20 well, near the depocentre incerpreted from isopachs (Figure 23). The depositional edge 


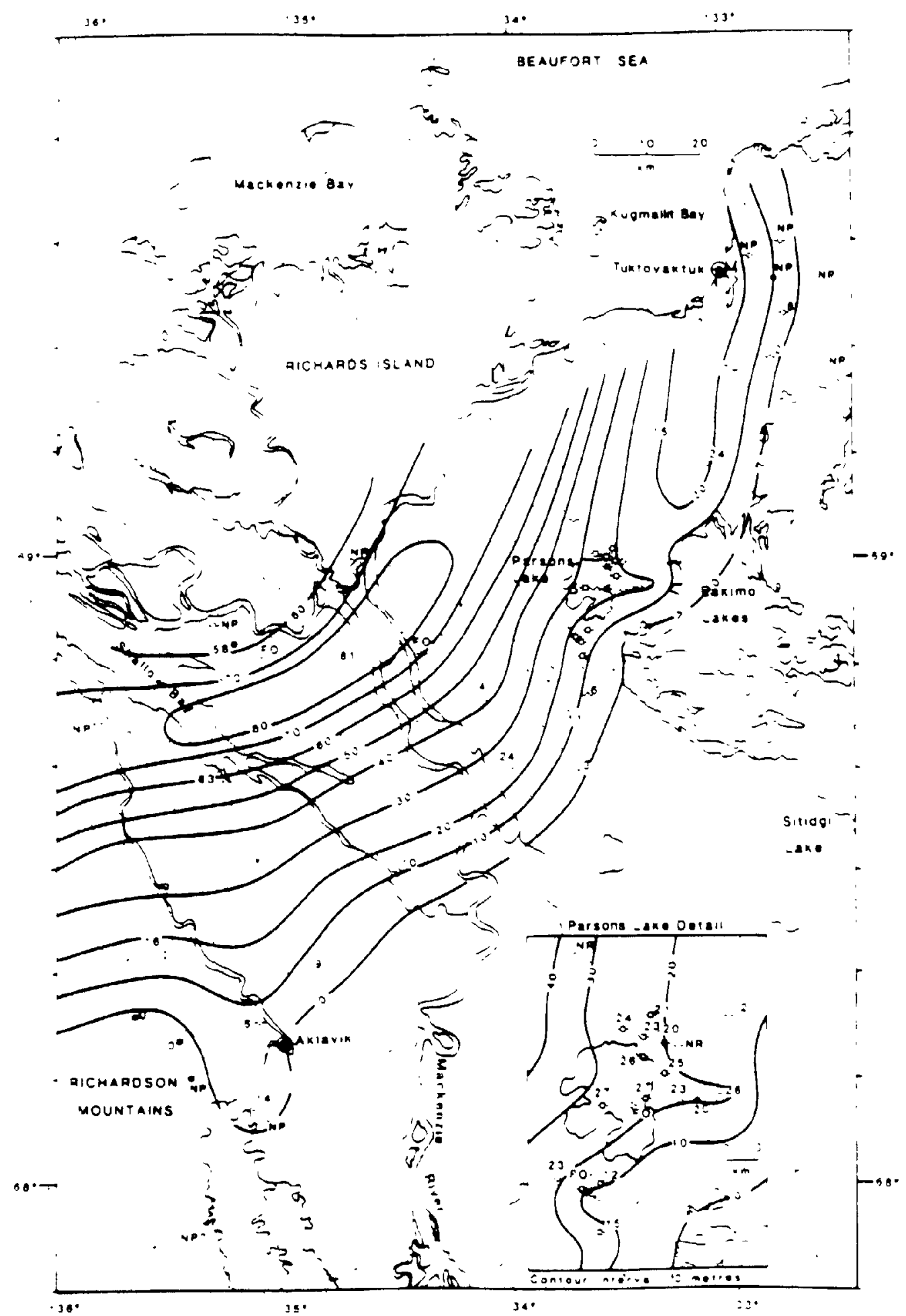

Figure 23. Isopach map of McGuire Formation (legend on Figure 18) 
onto the Eskimo Lakes Arch, reflects influences Erom the Canote Depression and Cache-Creek High. Contours parallel the Eskimin Lakes Arch attestingo to the major control exerted by that feature on depositional patterns. The Tununuk High is, recognized by the thinner strata present in the Kugpik J-13 well.

\subsubsection{Environmental Interpretation}

Jeletzky (1975) interpreted the deposizional envirune it: McGuire Formation lithostratigraphic equivalents 17 th. Richardson Mountains as predorinantly outer neritic to upper bathyal. Myhr and Young (1975, p. 249) interpreted the F-o9 core as lagoonal and tidal flat deposits.. Palynomorphs recovered from the same core indicated to Myhr and Gunther (1974) a lower cuastal plain setting and to Bridedux in Brideaux et al., 1975 ,p. 4) derivation from an upper codstal plain depositional environment. Dixon (1992b,p. 18) postulated a low-energy. nearshore, depositional environinent for the McGuire in general.

Déposits of the McGuire Formation extend Erom mid-way up the Tuktoyaktuk Peninsula westward well into the Richardson Mountains. Throughout the subsurface the fordation is interpreted by well logs to be a thin mudstone dominated unt: The stratigraphic and sedimentological consistency exhibited by the McGuire would only be expected in an extensive low-energy system. The intense bioturbation, mudstone dominated lithology, and the presence of glauconite all suggest a quiet marine 
environment. A lagoon and/or shallow bay environment, such as that suggested by coté et al. (1975, p. 627) may have been dominant close to the depositional edge of the Formation on the Eskimo Lakes Arch. The coarsening-up sandstone bodies, more

$r$ common in the Kugmallit Trough may, represent short-lived, partially preserved barrier bars.

The McGuire Formation strata thus represent an extensive short-lived transgressive pulse. According to Reineck and Singh $(1973$, p. 308) the rate of shelf mud sedimentation ranges from 6 to $135 \mathrm{~cm} . / 100$ years. Assuming deposition in an neritic seteing and also assuming the slowest rate of deposition for the thickest section of $81 \mathrm{~m}$ in the Kipnik $0-20$ well in the Kugmallit Trough, a maximum depositional life span of about 135,000 years is assigned to the Formation.

\subsection{Kanik Formation}

The Kamik Formation (formally introduced by Dixon, 1982b,p. 18), the thickest unit in the Parsons Group, contains almost all the sandstone as well as nearly all the hydrocarbon reserves (1.8Tcf, $5.1 \times 10^{10} \mathrm{~m}^{3}$ of gas-Langhus, 1980) at Parsons Lake. The type section of the Kamik Formaton is present in the Kamik F-38 well (Dixon, 1982b, p.51) $\left(68^{\circ} 57^{\prime} 25^{\prime \prime} \mathrm{N} ; 133^{\circ} 23^{\prime} 54^{\prime \prime}\right.$ w, from $3007 \mathrm{~m}$. to $3235 \mathrm{~m}, 9864-10,613$ feet). Vertically uniform, laterally persistent, lithologic units within the kamik Formation have been recognized by Coté et al. (1975), Myhr and Young (1975) and Dixon (1982b) but mapping of pos(sible 
subsurface members has not before been attempted. In this thesis the Kamik is informally divided into three members based upon log response (gross lithology', overall sand percentage, nature of sand bodies), core studies (petrography, sedimentary structures, environmental interpretation), $\log$ correlations, and biostratigraphic information. These members, in ascending order, are the non-marine member, the transitional member and the marine member.

\subsection{Non-Marine Member}

The contact between the basal non-marine member of the sandstone-rich. Kanik Formation and the underlying McGuire Formation is easily discernible on the basis of $\log$ response. As discussed in the previous section, the lower contact is locally erosional. The upper contact between the non-marine and overlying transitional member is everywhere gradational, bat is arbitrarily placed at the top of the uppermost sand body in a sequence consisting of generally greater than $80 \%$ blocky, clean. (as shown from gamma-log response), closely-spaced. sands. Above the contact, strata are more shaly and carbonaceous (from soniclog response and petrographic studies), and the sands are thinner, more widely spaced, and generally fine.upwards. The non-marine member injthe Kamik F-38 well is all clean sand, compared to an approximately 22 percent clean sand content in the overlying transitional member.

The non-marine member has been cored in the Parsons $\mathrm{N}-10$, Parsons. L-43, Wagnark, $-23^{\circ}$ and Ikhil I-37 wells (Figure 24 ). 



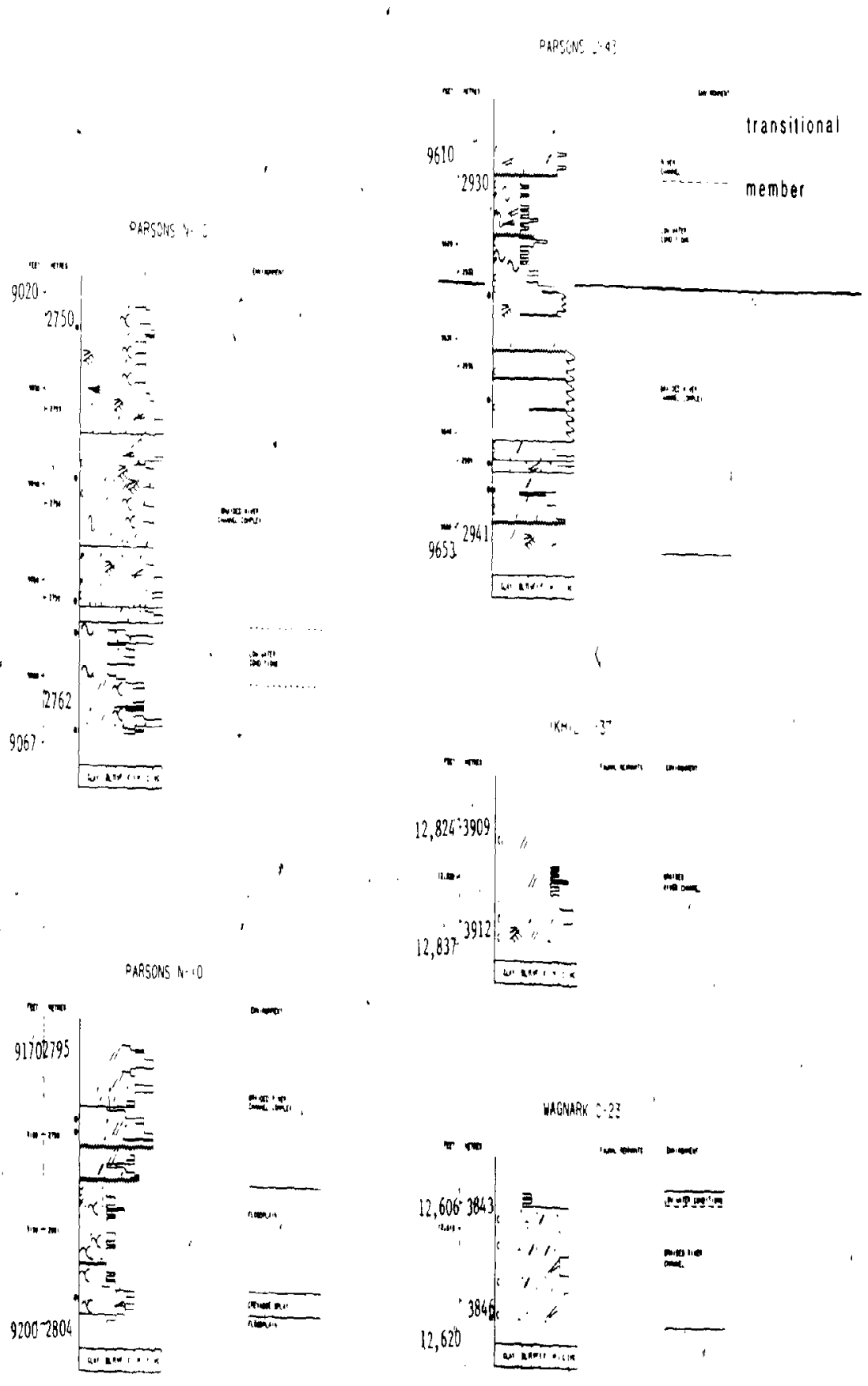

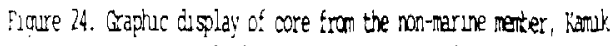
Fomation. All depths corrects to log depths.

For detailed core display see pizures 46 to 48 inc. (in jocket). 
Two intervals totalling 23 metres were cored in the Parsuns $\mathrm{N}-10^{\circ}$ well (Figure 46). The interval from 2795 to 2804 metres consists of burrowed and biocurbated black shale and interbedded lightgrey siltstone with thin coal seams and minor rippled and horizontally bedded fine-grained sandstone. It is overlain by a thin ( 1 to 2 ?metres) erosive fine to coarse-grained high-angle cross-bedded sandstone containing numerous shale rip-up clasts. The 14 metres cored from 2749 to 2763 metres contain medium to very cuarse grained slightly fining-upwards sandstone, with at least Elve sand bodies containing abundant basal and : reerspersed pebbles and shale rip-up clasts. The dominant sedimentary structure is high angle cross-beddtrg. The sands are locally carbonaceous and commonly contain thin irregular (sumetimes stylolitic) shale and carbonaceous shale stringers. Silty shale near the base of the core is extensively burrowed.

A 13 metre core in the parsons L-43 wll (Figure 47) crosses the boundary between the non-marine and transitional members. As defined here the lower part, (non-marine member) consists of thin, medium to very coarse-grained quartzose, slightly carbonaceous sandstones, characterized by high angle cross-bedding. Numerous pebble and/or shale rip-up clasts are present at the base of most beds. Iwo beds show very thin repetitive fining-up sequences and thin coal stringers and lenses. The upper part (transitional) is bioturbated, carbonaceous shale and siltstone exhibicing minor lenticular and convoluted-bedding. 
Short cores from Ikhil I-37 see Plate 1)and Wagnark C-23 (Figure 48) are carbonaceous mediup to coarse-grained quartzose sandstones, The Ikhil I-37 core contains high, angle crossbedding and shale rip-up clasts, whereas the Wagnark $\mathrm{C}-23$ core contains abundant scattered pebbles and woody fragments.

\subsubsection{Depositional Patterns}

Figure 25 shows subgorface i popachs of the normarine member, Kamik-Formation. The thickost known section $1+\angle 2$ metres) is in the Kipnik $0-20$ well. The 76 metre section measured by Jeletzky (1975) in the Richardson Mountains and assigned by him to the Martin Creek Formation lithostratigraphic equivalent has a typical lower Kamik lithology and is herein correlared in part with the non-marine member. The Eskimu Lakes Arch continued as a positive Eeature and the Cache Creek Uplitt and Tununuk High were active, with significant thinning or absence of the non-marine member over these positive Eeatures. Although thickness information is lacking in the northeastern Richardson Mountains, from isopach trends it appears tha't the Cache Creek Uplift was an emergent feature throughout deposition of the non-marine member and the Kugmallit Trough was isolated irom the Blow Trough to the west. Stratigraphic data from the Richardson Mountains collected by Jelfrzky (1975) supports the presence of an areally limited Canoe Depression. The Napoiak High is not recognized. The depositional edge proposed in Figure 25 is based on the good well control on the western flank of the Eskimo Lakes Arch. The absence of the non-marine member on the Arch is mainly due to non-deposition and not erosion since 


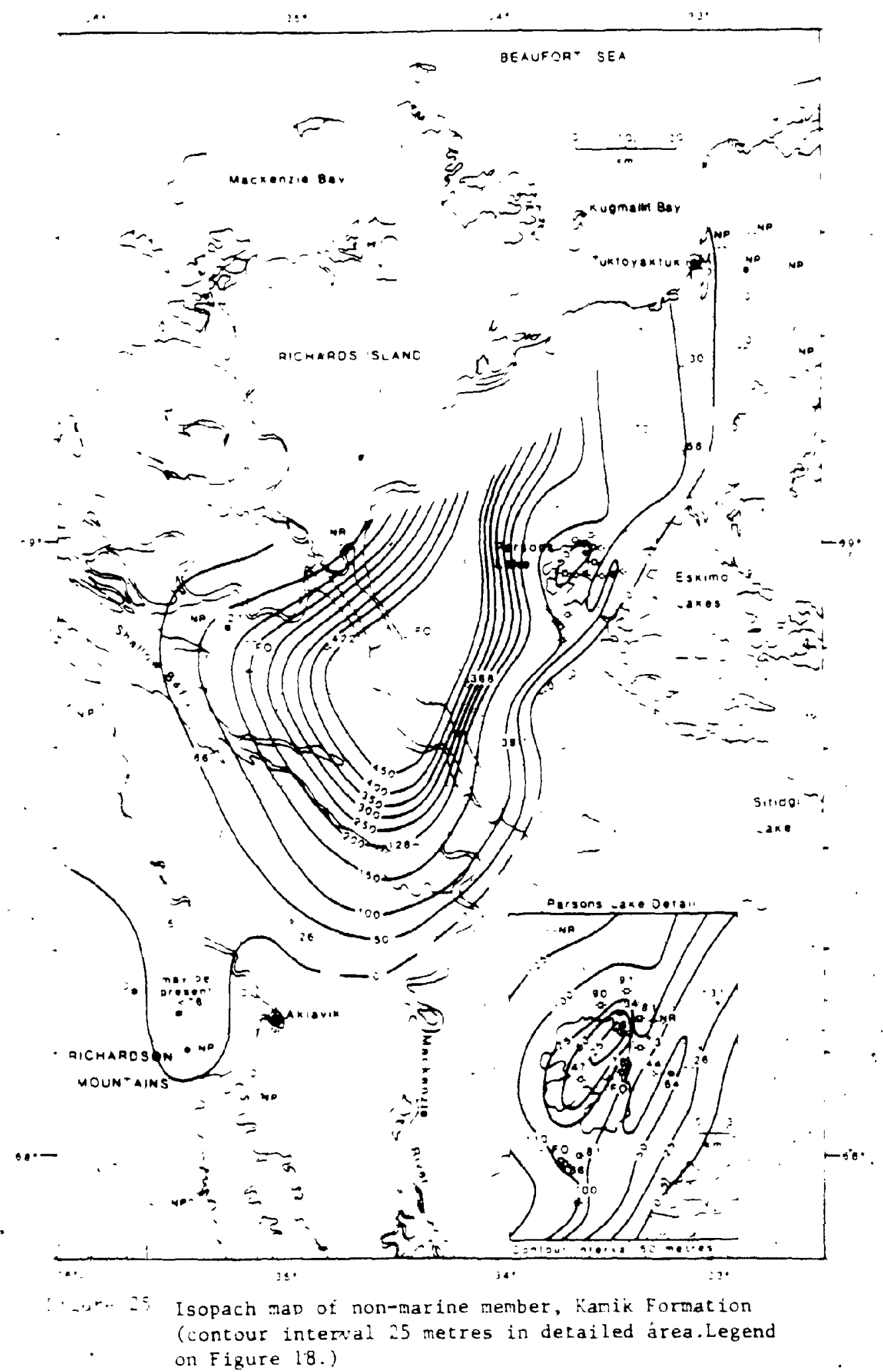


deeper-water Kamik Formation strata (pre-Middle Hautrivian; ar. extensively on the west tlank of the archandintne caci. Creek Uplift. If any erosion of the non-marine member tuok plack it was probably local and short-lived. Isopach valates til depositional patterns of the Kamik Formation non-marine minbs. provide insight as to the major conterporaneous tectin: Eedtures of the area at the time of dposition. The alls:l: deposition postulated woild have been influenced by copibring: Ear more than the deeper water sedimentation which prected at: followed this depositional interval. Besides revealing in. larger structural features previously discussed, the is spach alsu show significant local stratigraphle thinnlig in the Parsions Lake Area, and exceptional thickening in the kugrall: Trough. Stratigraphic thinning in the Parsuns lake drea is Lnterpreted as a response co contemporaneous Ealt novenen: assuciated with increased subsiance in the Kugmaliz Trough. The circular thinning revealed in che parsons lake area colncides remarkably well with the structural extent ut tho anticline associated with the North Parsuns Lake gas pool.

\subsubsection{Environmental Interpretation}

A non-tarine alluvial origin has been interpreted far this member by all previous authors.' Myhr and Young 1975, Figure 42.8) proposed a delta plain origin for equivalent strata tbasal third of kamik Formation) Coté et al. (1975, p.627) suggested a non-marine cyclic fluvial environment.

Dixon (1982b) discrimated between Fluvial channel. 
crevasse splay or levee and flood plain deposits in his work on the lower Kamik.

Young (in Shawa, 1974) interpreted the $N-10$ coré as distributary channel deposits of a delta plain environment.

Interpretation of core data, well-log responses and biostratigraphic work allow an evaluation of the depositional environiment in the lower third. of the Kamik Formation.

The lack of marine fussils and common carbonaceous content of the strata suggest a non-marine origin: Palynomorphs and foraminiferal studies by Gulf Canada Resources (unpublished data) in Calgary indicate a non-marine setting for lower Kamik strata (non-marine member). in the Parsons $\mathrm{N}-10^{\circ}$ and Ikhil I-37 wells and a non-marine to coastal transition interpretation for equivalent rocks in the Patsons F-09, Reindeer G-04 and Beaverhouse Creek $\mathrm{H}-13$ wells.

The alluvial deposits of the non-marine member are typically sandstone-rich. Minor fining - up trends can be detected in the core and from the well-logs. Erosional contacts, pebbles, shale rip-up clasts and high angle crossbedding are typical. The widè extent and strafigraphic consistency of the sheet-like unit and the lack of flood-basin and chaninel - fill deposits suggests deposition was in a braidplain environment. The lack of debris flows, the 
compositional and textural maturity of the sediments and lateral continuity of the strata discount an álluvial fan origin. Numerous general models of braidplain deposition have been developed (Miall, 1978), an important controlling parameter being the distance from source. At the base of the non-marine member in some wells (eg. Napartok M-01, Reindeer A-01, see Figure 5) the interval lacks mudstone and sands appear particularly blocky on logs. Such a vertical sequence is analogous to the sourceproximal Bijou-Creek braid-platn model (Rust in Miall, 1978). More typical of the non-marine member is a cyclical deposition of sandstones interbedded with thin mudstones (eg. Ikhil I-37, Reindeer G-04, Parsons N-10, see Figure 5). A possible analogue of such a depositional system is the source-distal South Saskatchewan River from which the South Saskatchewan braidplain model is derived (Miall, 1978).

Well-log data and core studies indicate that the south Saskatchewan River lithological succession (Cant in Miall, 1978) is analogous to the majority of the non-marine kamik strata. Sedimentary structures similat to those of the south Saskatchewan model are present, but information is inconclusive due to Iimited core data. The lithologic and stratigraphis characteristics of the South Saskatchewan-type braidplain vary Erom lithologically homogenous proximal sediments to.distal fining-up cycles with significant primary mud content (Rust, in Miall, 1978, and in Walker, 1979). These distal deposits may be transitional to those of a meandering fluvial system. The mudstones associated with braidplain deposition are limited to 
deposition on levels or terraces above the active tract (Williams and Rust, 1969), which are usually vegetated.

It is likely that close to the eastern depositional limit shown in Figure 25, braidplain' lithofacies and vertical profiles as in Reindeer $A-01$ and Napartok M-01, are of the Bijou Creek, Donjek, or even scott type of braided stream deposit '(cf. Miall , 1978). Basinward, meandering reams, or distal "muddy" South Saskatchewan type braided stream deposition would occur. Two Kugmallit Trough wells Kipnik 0-20 and Ikhil I-37 in Eact, do contain noticeably fining-upi sandstone bodies separated by significant thicknesses of 'mudstone (see Figures 5 and 6):lithologies typical of the distal South Saskatchewan brajdplain *. model.

3

An anomalous 120 metre thick saridstone body in the kipnik 0-20 well at the base of the Kamik Formation is thought to represenç delta front deposition whereas an equally anomalous 125 metre shale-dominated interval within the pustulated braidplain sandstones near the base of the Kamik Formation in the Ikhil I-37 well has near-shore marine log characteristics) These two stratigraphic occurrences suggest that braidplain streams may have, at least locally, emptied directly into coastal waters:

\subsection{Tranditonal neaber}

As discussed in the previous section, the contact between the transitional and non-marine members of the Kamik Formation 
is. placed at the cop of the sandstones interpreted as braided channel deposits. The upper limit of the transitional member is placed at the top of a sand body (usually with barrier bar characteristics) approximately two-thirds up the Kamik section. above which the strata are noticeably more shaly, less carbionaceous and commonly contain one or more coarsening-up barrier bar sand sequences (see Figures 5 and 6 ). Transitional strata consist of numerous thin sands interbedded with locall: carbonaceous mudstone, and thicker sands exhibiting either coarsening, or fining-up trends. The upper contact of the transitional member coincides. with the top of the informal $B-$ zone (Gulf Canada files) and can be easily mapped throughout the subsurface in the Parsons Lake area. In the Kamik F-38 type. segction well - 22 percenţ of the cransitional merber is clean sand, while in the oyerlying marine member 6 percent is clean sand.

The transitional member has been cored in 8 wells - Siku E21. Parsons L-43, Parsons F-09, Siku, A-12, Ogruknang M-31, Wagnark C-23, IOE Tuk F-18 and Reindeer A-01. Two intervals totalling approximately 28 metres have been cored in Siku E-21 (see Figures 26,27,49 and 50 and Plate 2). The lower interval consists of fining-up sequences of Fine to coarse-grained sandstones with abrupt, possibly erosional bases. Thin carbonacous sandstone bodies in the centre of the core, interpreted as crevasse-aplay deposits, show high angle cross-bedding. cliabing-ripples, shale laminae, wavy and convoluted-bedding and 


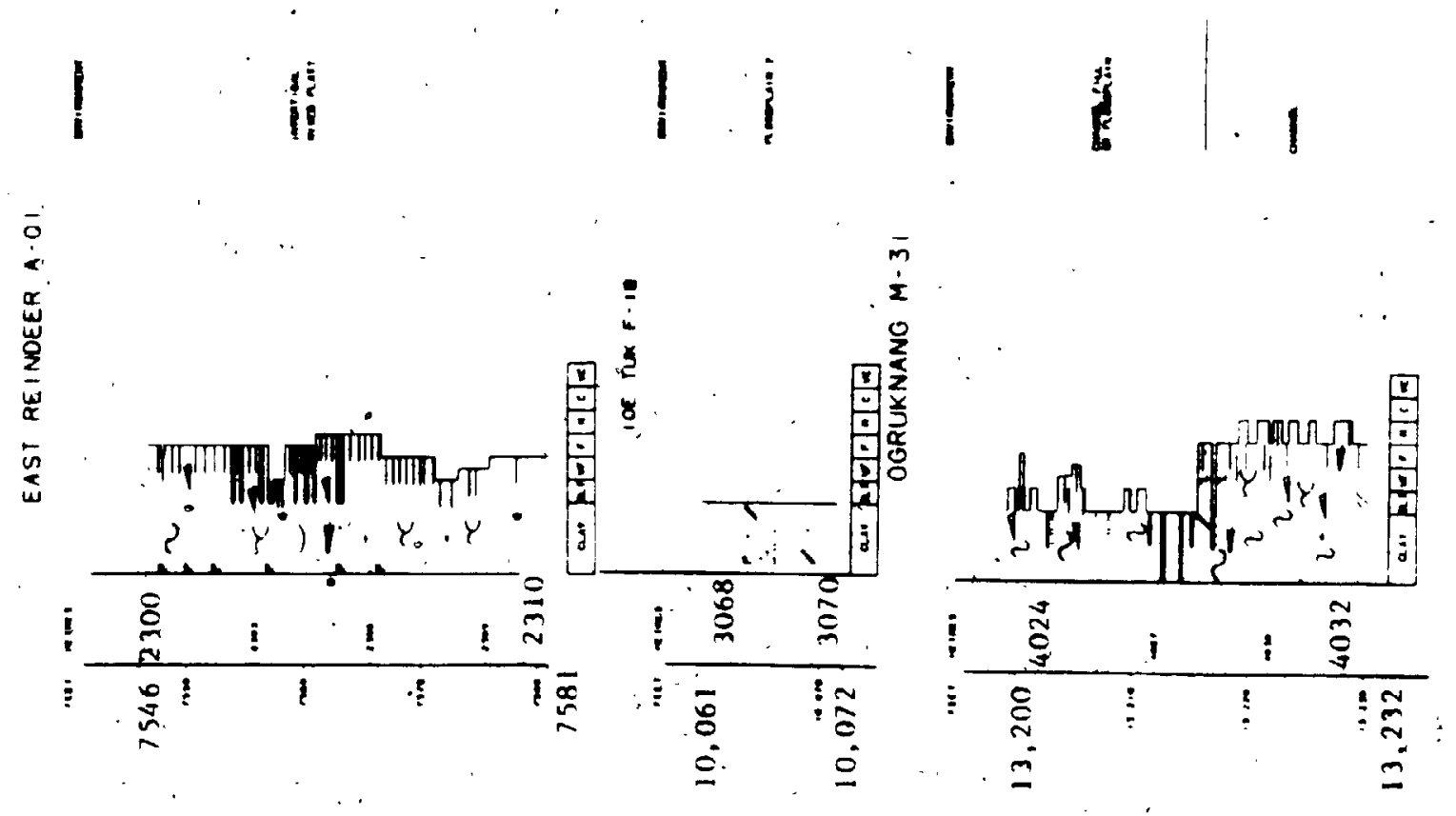

IHU H I I I I I

0
0
6
0
8
0
0
$\frac{9}{2}$
$a$

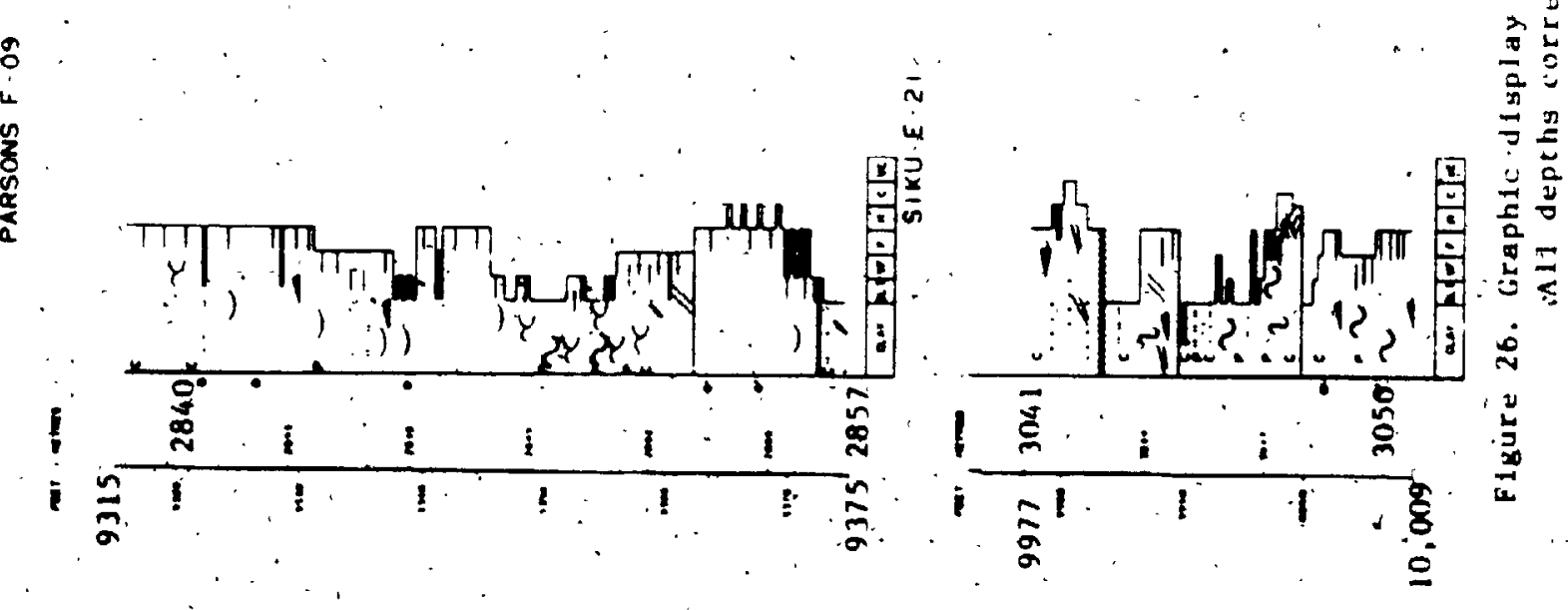



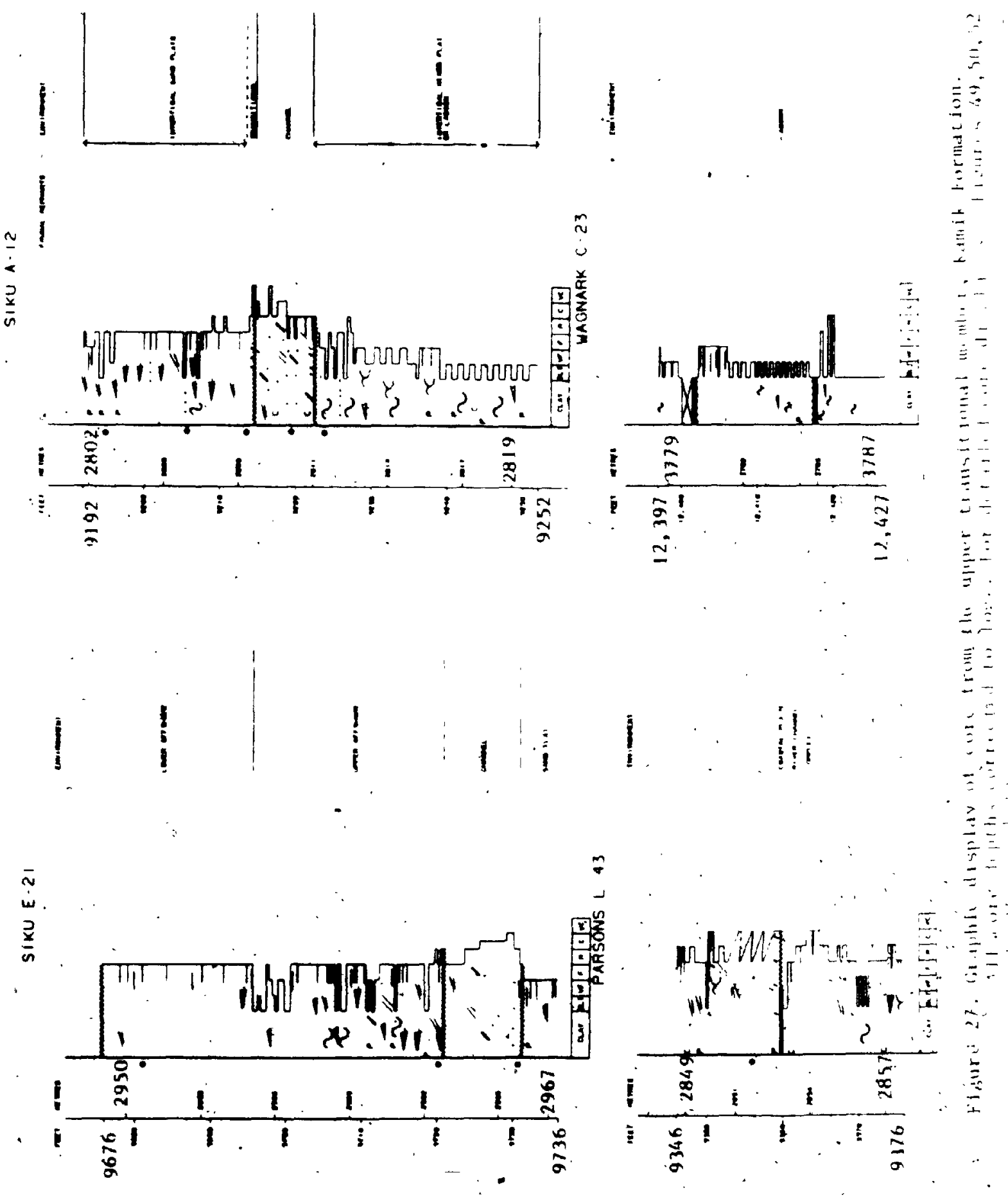
minor burrowing. Directly overlying the sandstones are silty carbonaceous shales. The sand, bodies at the base and top ut the core are examples of upper and lower channel bars respectively. The upper channel bar terminates in shale grading upwards from a' fine-grained quartzose sandstone, containing numerous shale laminae, cliobing-ripples, wavy-bedding and burrows. The lower channel bar is a pebbly, coarse-grained carbonaceous quartzose sandstone with subhorizontal bedding and low angle crossbedding. The upper core is of a decidedly more marine nature. The sandstones typically contain numerous shale laminae and low angle cross,-bedding (see plate 4d), ripple marks, and wavy bedding. Chondrites cf, burrows are recognized (see plate 5a), lower in the core, Helminthoida cf. may be present as well. (Plate 5b). The overlying strata are relatively clean, tinegrained, quartzose sand with ninor horizontal bedoing and low angle cross-bedding. Chondrites cf. burrows are much more abundant and Skolichos cf. burrows may be present. A 3 metre fining-up erosional channel sand present near the botcom of the core contains numerous chert pebbles at the base and both high and low-angle cross-bedding dips at the top of the unit. The position of this channel sand amidst relative quiet water deposits suggests a posible delta-related submarine-origin.

The lower fore in Parsons'L-43 (Figure 50) cuts, the transitiopar - non-marine contact (Figure 26). The base of the transitional member consists of interbedded, burrowed, carbonacedus silitstone and shale containing lenticular and $\therefore \quad$ slumped bedding, minor coal and ripple marks, probably deposited 
in a channel fill or flood basin environment. Overlying this shaly section, in an erosional manner, is the carbonaceous, medium to coarse-grained basal section of a quartzose channel sand containing numerous interspersed pebbles and low angle bedding dips as the only recognizable sedimentary structure. The 9 metres of core near the top of the transitional member is " within a series of fine to coarse-grained cyclical fining-up quartzose sandstones. The strata contain numerous coal lenses and seams, shale rip-up clasts (mainly at the base of one major erosive channel), and both high and low angle cross-bedding.

Approximately 18 metres of core in the Parsuns F-09 well (Figure 51) is cut from the transitional member (Figure 26). The bèds are mainly very fine to fine-grained quartzose sandstone and generally featureless except Eor shale, laminae and contain zones of pipple marks, flaser bedding. shale rip-up. clasts and one zone of high-angle bedding. Interbedded $\hat{s} i l t y$ or sandy shale zones are present, usually irregularly or lenticularly bedded. Bioturbation is of a moderate to locally intense nature. The strata are interpreted as a coastal sand sequence consisting of A coaly shale zone at the base of the core thought to represent màrsh deposition is overlain by dominantly intertidal and lagoonal deposits. Myhr and Young (1975, Figure 42.8) interpreted this core as delta plaip to deltá frônt/prodelta deposits. The uppermost sand is interpreted as a transgressive sand by Dixon (1982b) and this view is. supported in this thesis. 
Approximately, 20 metres were cored from near the top of the. transitional member in the Siku A-12 (Figures 27 and 52 and Plate 3). The lower part of the core consists of a cuarseningup interbedded sequence of shale, siltstones and very finegrained sandstones. Starved ripples, lenticular and irregular bedding and moderate to intense burrowing is common throughout the rock. Diplocraterion.cf. and Teichichnus cf. buțrows were recognized. Based on the lithologic sequence and sedimentary' scructures present, an intertidal mixed flatboth sand and mud, Reineck and Singh, 1973) or lagoon depositional setting is Eavoured. Overlying these beds is a 2 metre thick, dominantly redium-grained probly, carbonaceous and coal-bearing quartzose sand body (see Plates $4 \mathrm{a}$ and 4b). A moderately bioturbated, Einegrained sandstone body containing minor shale beds and common Low angle bedding dips (Plate 4c) and cross-bedding overlies the channel sand in a somewhat erosional manner. Asterosoma cf. burrows may be present. Rocks in this core suggests a persistent intertidal coastal margin within which rapidly rigrating tidal channels existed.

The approximately 10 metres of rock cored from the middle of the transitional member in Reindeer A-01 (Figures 26 and 54): is tentatively interpreted as having been deposited in an intertidal mixed flat. The strata are mainly, very finegrained, locally rippled and cross-bedded, quartzose sandstones interbedded with numerous thin shale beds which contain siltstone and fine-grained zanes. Bioturbation and burrowing is moderate throughout most of the core with possible Chondrites s. 
cf. burrows recognized. Pyrite, glauconite and concretions ate present.

Approximately 9 metres of core from the Ogruknang M-31 well (Figures 26 and 53) is located within the fining-upwards, midrich stream channel facies of the transitional menber. The cuarse channel clascics are fine co nedium-grained, locally argillaceous, and exhibic ripple marks, low and high angls cross-bedding and common convoluted-bedding. These cuars. clastics grade abuptly into a coal-bearing noderatel: bioturbated, shale dominated lithology interbedded with this coarser clastic beds near the top of the core. Starved ripples are recognized in the coarser beds.

The 10 metres of rock cored from near the top of the transitional member in the Wagnark $C-23$ well (Figures 27 and 53) is dominantly a quartz wacke interbedded with thin siltstone and some coarser.clastic zones. Three thin coal seams were noted, as well as common wavy and lenticular-bedding and (climbing)? ripple-lamination. Burrowing and bioturbation occurs sporadically throughout the core, with Rhizocorallium cf. burrows probably present.

The 1itcle more than 3 metres of silty and sandy.slightly bioturbated woody shale cored from the IOE Tuk F-l:B well shows lithological similarities to flood basin deposits (Figures 26 and 54), but this interpretation is gentative.
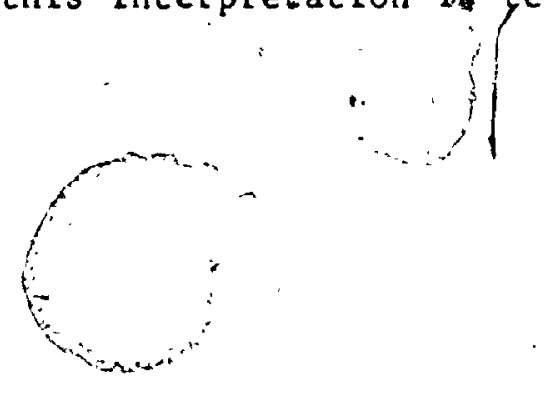


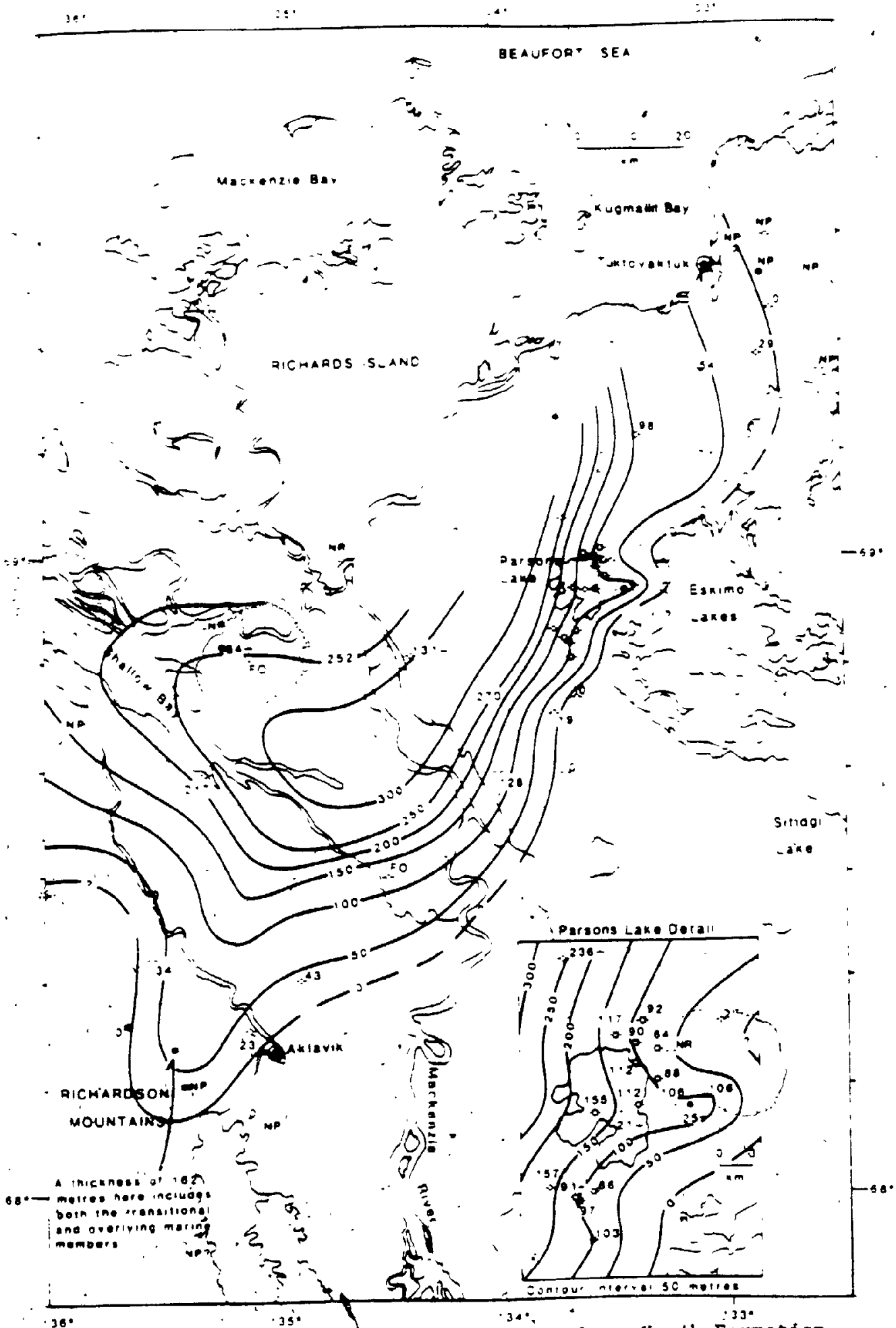

Figure 28. Isopach map of transitional member, Kamik Formation (legend on Figuge 18) 


\subsubsection{Depositional Patterns}

Figure 28 is an isopach map of the cransitional menber lil the Mackenzle Delta region. Depositional patterns are sintlar to those exhibited by other parsons Group units. Both the Canot Depession and the Cache Creek High were active durlng deposition: The thickest section of 270 metres was encountert: in the Ikhil I-37 well. The depocentre appears to be lucatet between the Kipnik 0-20 and Ikhil I-37 wells. Thickness values show that depositional connection between the kugrallit and Biow Troughs was restored. Contours may open to the northeast.

A depositional arm extending cowards the arch is recognized in the Parsons Lake area encompassing the Kanik D-48, D-58 and F-38 wells. As discussed earlier, the thickening present here may have: been associated with contemporaneuus fault movenerit. probably related to a transverse faulc systen oriented nearorthogonal to the dominant north-northwest structural teend.

Sandstone isolith thicks (Figure 33) mimic isopach thicks in the Parsons Lake area. Although control in the area is good it can only be postulated that associated with this zone of subsidence was a higher frequency of channelling probably associated with drainage off the Eskimo Lakes Arch.

$$
\text { i }
$$

\subsubsection{Environmental Interpretation}

- The transitional member, a consistent vertical depositional succession, represents environments of deposition ranging from meandering river channel and flood basin (distributary in part) 
to offshore. Both Coté et al. (1975) and Myhr and Young (1975) recognized the presence of non-marine rocks ell into the middle Kamik Formation. These authors interpreted what is here called the transitional member as an interbeding of marine and nonmarine, rocks with little sedimentological consistency. Dixon (1982b, p.18) recognized a progressive depositional change throughout the Kamik, which expresses itself best in the cransitional member.

Enviconmental interpretation of cores form the basis of the overall depositional model. "Table 2 shows the location of the cores within the transitional member and the environmental interpretation. The lower transitional member cores are nonmarine fiuvial deposits whereas straca cored from the middle and upper transitional member are more marine.

Log responses suggest that this environmental succession is present throughout the subsurface (eg. Parsons F-09, Reindeer G04, Reindeer A-01, Imnak J-29, see Figure 5).

The sedimentological succession is thus interpreted as a response to trangressive conditions varying from non-marine meandering channel deposition to offshore marine. Fluvial deposition progressed from braidplain in the underlying nonmarine member to a more meandering style due to either lessening regional gradient or sediment supply. Overlying these nonmarine rocks are marginal and coastal sediments, characteristi- 


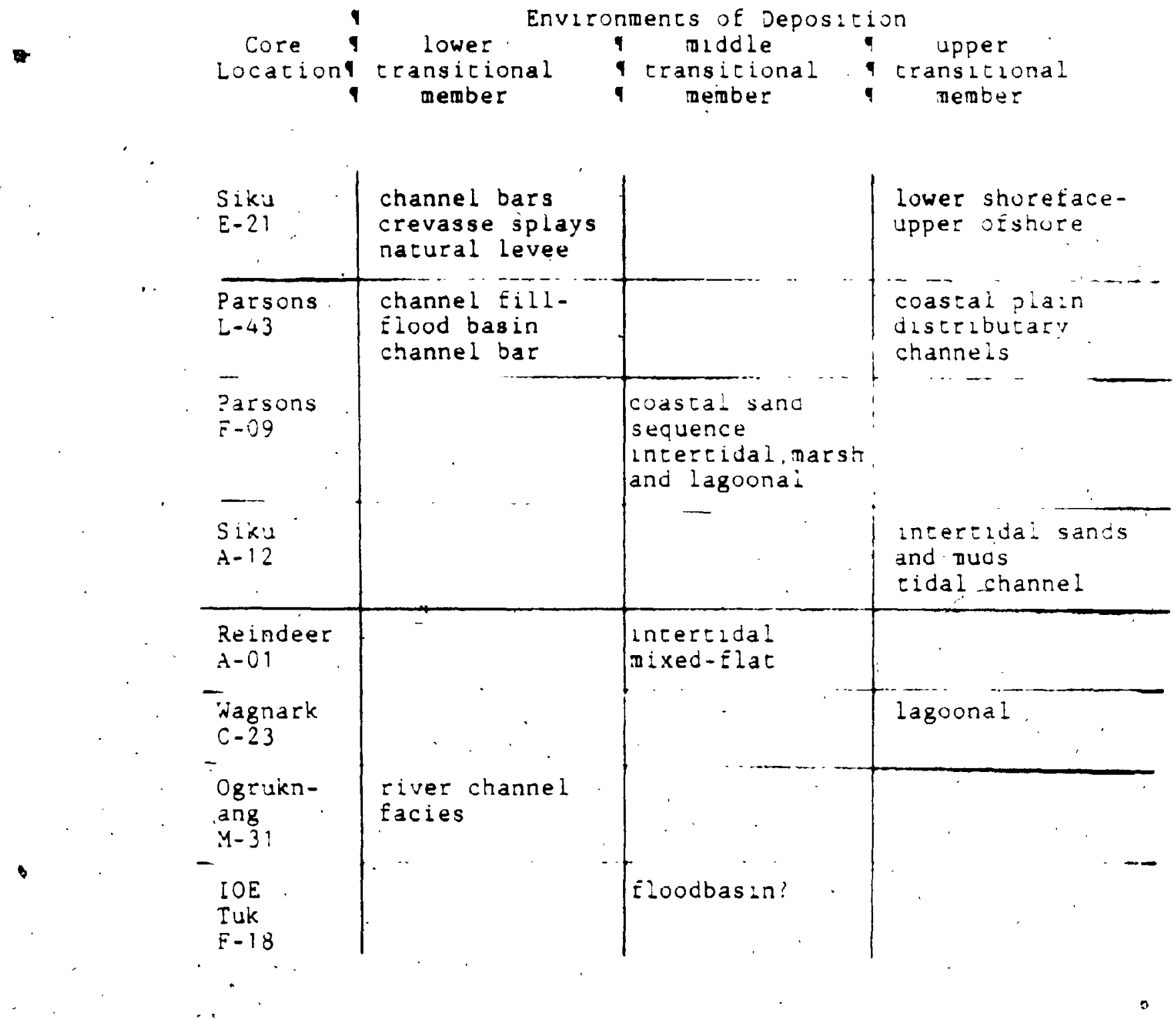

Table 2. Environments of deposition for the cransitional member. Kamik Formation. 
cally carbonaceous and more thinly interbedded. The spectrum of possible environments in the transitional member is the greatest of any Parsons Group unit.

With the continuing transgressive fconditions, all coastàl systems were drowned. Throughout the subsurface, the final deposits of this trangression are usually in the form of barrier bars. Ultimately this barrier bar system was drowned signaling the beginning of continuous marine deposition (see figures 5 and 6).

\subsection{Marine Menber}

The base of the marine member is placed at the transition to a shale-dominated sequence. The top of the marine member coincides with the top of the Parsons Group and is placed above the last sand underlying the shales of the Siku Formation.

The marine member has been cored in 7 wells - Reindeer G04, Parsons P-41, Siku A-12, Parsons L-43, IOE Tuk F-18, IOE PikiolikE-54, and Siku E-21: Approximately 18 metres were cored in the Reindeer G-04 well (Figures 29 and 55). The base of the core consists of bioturbated interbedded shale and siltstone containing minor horizontal-bedding and low angle cross-bedding. A thin, very fine-grained sand is present, its base being abrupt but not noticeaby erosional and containing coarser clasts and shale rip-up clasts. The remainder of the lower core consists of thinly interbedded burrowed and bioturbated offskore shales and silfstones exhibiting local low angle cross- 


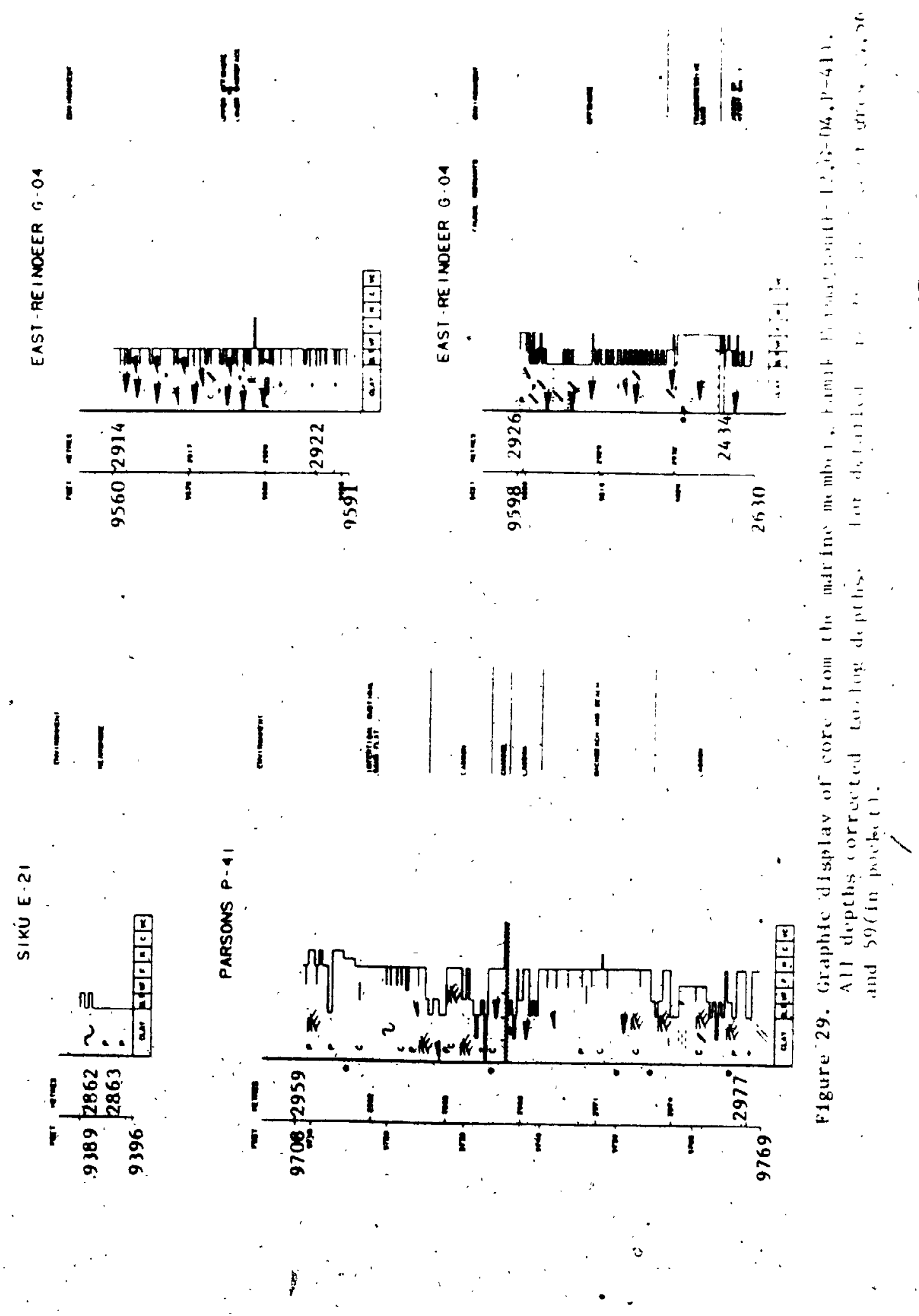


Dedding and containing woody tragments and siderite(?) concretions. The overlying core is siltstone - dominated, containing numerous shale laminae and thin beds. The siltstorie commonly exhibits ripple cross-laminae and horizontal-bedding. Siderite(?) concretions are common. Beds here are extensively burrowed and bioturbated, with Terebelina cf. and Chondrites CE. burrows reçognized.

Approximately 18 metres cored in the Passons P-41, well (Figures 29 and 56), appear to be from a complex series of nearshore environments including lagoon, intertidal and subtidal sand Elats, chainnel and backbeach and beach (based on ichnology and lichology). Plate $4 \mathrm{f}$ exhibits the conglomeratic channel base seen in the core. The rock is generally fine-grained. Lagoonal strata are shale-dominated and commonly contain thin coal seams and beds. Local biuturbation is common. Plates 5d,e and f exhibit burrows of Chondrites cf. and Teichichnus sp..

The 18 metres of Siku A-12 core also from a complex series of nearshore environments (Figures 30 and 57), consists of fine to medium-grained, carbonaceous, high and low anglé crossbedded, and rippled; laminated, coal-bearing rocks... The shaledominated, bioturbated strata, incerpreted as ligoonal deposits; are interbedded with coarser sands of tidal flat orìin. A Teichichnus cf. burrow was recognized during core inspection at the top of the core (Pląge $5 c$ ).

The 18 metres of core cut in Parsons L-43 represent, for the most part, a coarsening upwards. barrier bar (Figures 30 and 


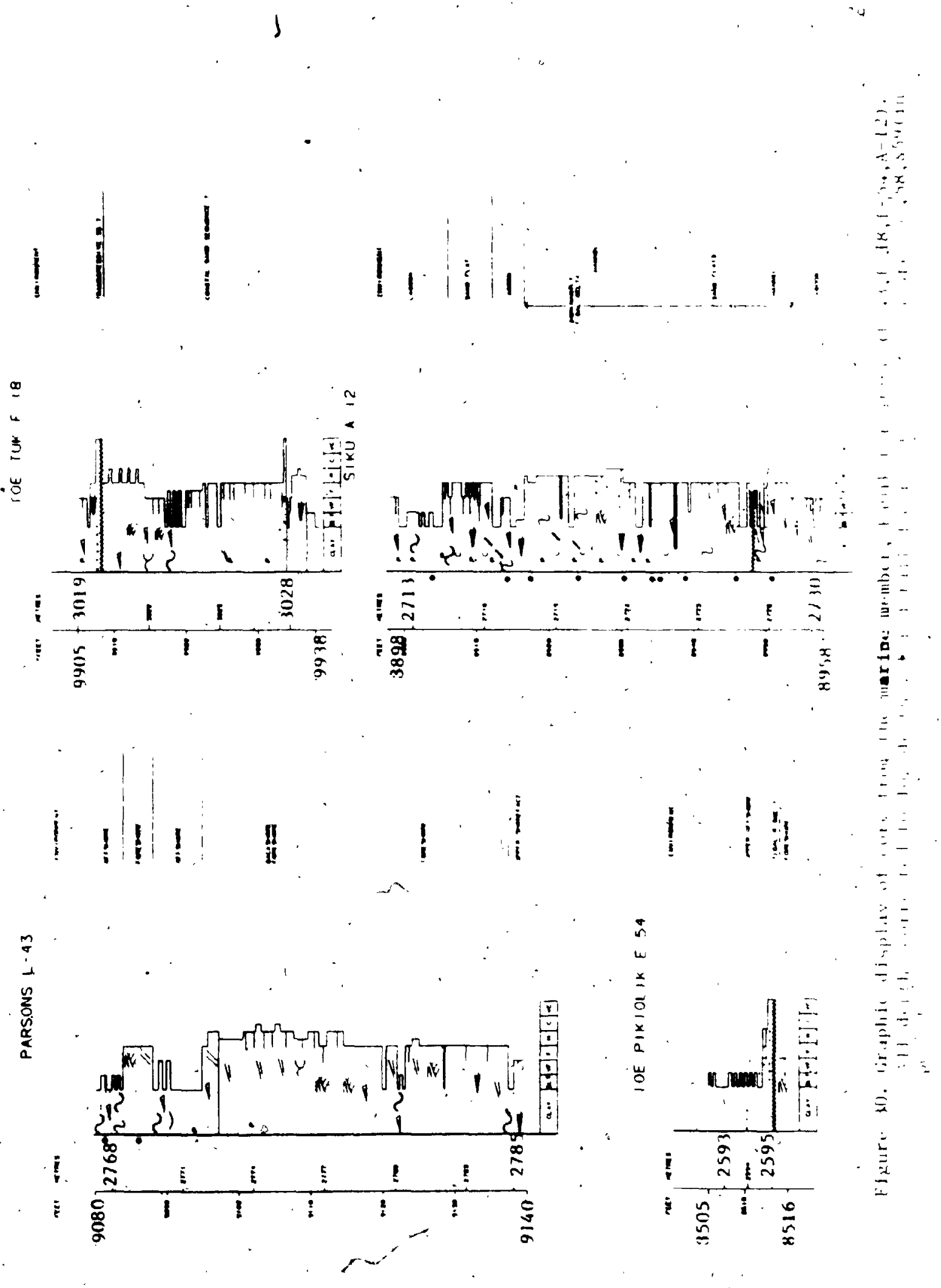


58). The sediments range from very fine-grained horizontallybedded and low angle cross-bedded sandstones of the upper shoreface environment, through the fine-grained high and low angle cross-bedded foreshore sands into a.dominantly mediumgrained generally sub-horizontally bedded sandstone of the backshore to foreshore depositional regime. The system appears tu have been rapidly drowned, being overlain by shale-dominated uEshore deposits.

Nearly 10 metres cored in the IOE Tuk F-18 well (Figures 30 and 59) are incerpreted as a coastal sand sequence of uncertain origin. The rocks are dominantly fine-grained burrowed and bioturbated sandstones containing erosional and abrupt pebbly basal lags, ripple cross-laminae, and both low and high angle cross-bedding. Near the top uf the core a thin, erosive, trangressive sand is present.

Rock cored in the 'IOE Pikiolik E-54 well (Figures 30 and 59) appears to be dominantly upper offshore (as shown by the lithological assemblages and presence of Chondrites cf. burrow Chaberlain, 1978) and foreshore in origin. A thin erosive, pebbly, very coarse-grained sand body separates the upper oftshore and foreshore deposits and way represent a tidal ridge deposit:

The 2 metres of burrowed shale and siltstone cored from the Siku E-21 well (Figures 30 and 59) are interpreted, through its 
stratigraphic setting to be nearshure in origin. "Plate ta" exhibits wavy-bedding present in the rock.

\subsubsection{Depositional Patterns}

Figure 31 is an interpretive isopach reconstructing original thicknesses in the marine member. It is postulated that the Tununuk High was still a prominent structural feature. Contours reflect this, showing thinning over this high. It is, noteworthy that the marine member extends much further onto the Arch than older Kamik scrata. The Cache Creek Uplift and the Canoe Depression are less obvious than in underlying kamik rocks. The ihickest section of 330 metres is in IkhIlil-37. just northeast of the postulated depocentre. Contours appear io open to the northeast, whereas deposition was apparencly still somewhat restricted to the west by the Cache Creek Uplift. $\therefore$

Anomalous thins in the isopach patterns near, and north of Parsons Lake, most likely reflect a combination of barrier bar "deposition and sedimentological response to structural highs in the area. The prominent depositional thick to the east of Parsons Lake coincides with the embayment recognized in the transitional member isopach, and no doubt reflects continued local subsidence, probably within a local fauleed zone $\because$ Sandstone isolith thicks (Figure 34) contrast markedly with isopach thicks in this area of local subsidence. Apparently, sand was deposited as a result of shoaling on highs, whereas low-lying areas were not conducive for coarse clastic sediment deposition in this dominantly offshore - nearshore environment. 


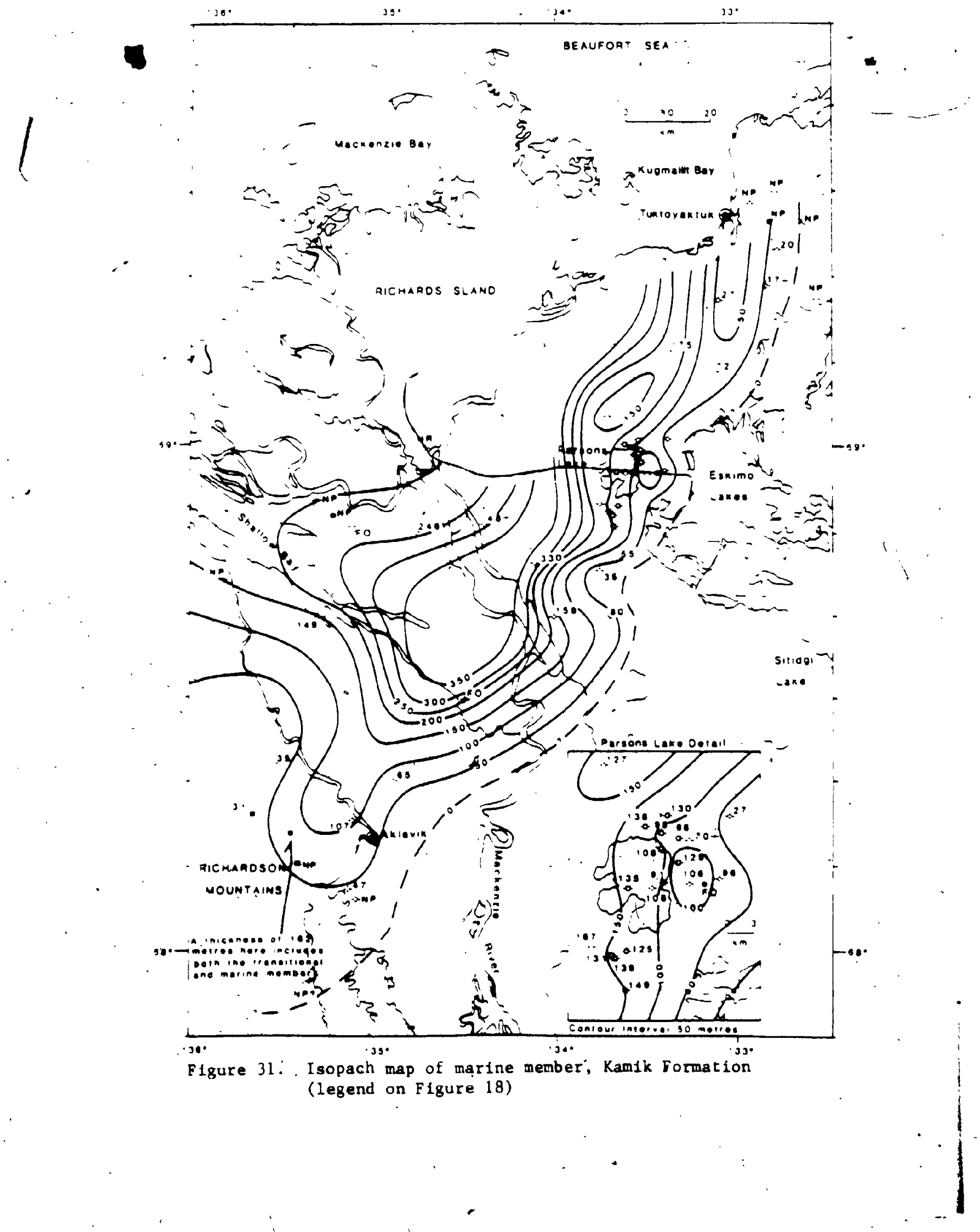




\subsubsection{Environmental Interpretation}

The marine member of the Kamik Formation has been interpreted as marine by previous authors. Coté et al., (1975, p.627) recognized barrier island cycles, whereas Myhr and Young (1975) interpreced these same coarsening-upward sands as prodelta to delta front deposits Dixon. (1982b, p.23) interpreted the coarsening-upward sands of the marine member as barrier island deposits and associated deposits as lagoonal, tidal channel, shoreface and offshore, similar to the interpretation presented in this thesis.

Coarsening-upwards' log responses of 'marine member strata proximal' to the Eskimo Lakes Arch, such as in wells Reindeer A01 , Reindeer $\dot{G}-04$. (see Figure 5), Parsons L-43, Parsons D-20, , and Reindeer C-38 suggest strongly the presence of barrier is lands, especially when combined with the core data obtained Erom Parsons $L-43$ and Reindeer G-04. The expected associated lagoonal, intertidal, nearshore and offshore deposits are confirmed by the data from available cores.

Conspicuously absent are barrier bars away from the Eskimo Lakes Arch. In wells Ikhil I-37, Kipnik 0-20, Unak B-11 (see Figure 6), IOE Tuk F-18 and Wagnark $C-\$ 3$ the sands are generally thin and featureless and no barrier island deposits can be recognized with the degree of certainty which is possible in the Parsons Lake area. 

The high net sand"percentages near the Fskimo lakes ir:h (icy the coastine) probably indicate that barrier bar Eormation was limited to nearshore (Dickinson et al. 1972). The location of the depositional edge of the marine member in Figir. 31 is in part based upon this relationship.

In the steadily deepening epeiric sea which likely exis: $\because$ In the Mackenzie Delta region at the time of the upper ne: deposition, barrier island sand bodies would nave oe... stationary or landward migrating. Deposits basinward ue the barrier island complexes would likely have been typacai i i sandy shelf environment.

Coté et al. (1975) and Myhr and Young (1975) suggested that the boundaries between successive deposits analogous to the members proposed in this report are major diachronous facies boundaries. Dixon (1982b, p.23) suggested that unly a sligh: diachroneity exists within the subsurface Parsons Group. The lack of any recognizable barrier bar/island sequences basinwart in the marine menber supports Dixon (op. cit.) and suggests rapid regional tectonic change since in a highly diachronous depositional regime, barrier sand bodies fold have first iurmed in a more basinward location and migrated landward with deepening water levels.

\subsection{Sand I soliths}

Semi-quantitative mapping of sands was achieved using gamma 
ray response from down-hole logs. A "sand line" was drawn twothirds of the way up from the common shale response to the cleanest sand responsei a standard procedure in the petroleum industry. It is deduced through petrographic scudy that all gammay responses above this sand line represent clean and possibly reservoir quality sandstones and as such were included in the sand isoliths.

The sand isoliths show regional sand trends. In areas of high control, such as the Parsons Lake field, detailed variations are apparent.

Sand isoliths of the non-marine, transitional and marine members of the Kamik Formation were constructed to represent original depositional sand thicknesses. Figure 32 is the interpretive sand isolith map for the non-marine member. Sandstone thickness patterns are very similar to the isopach for the member, as would be expected in a braided stream depositional system. The sandiest.section of 280 metres was encountered at the kipnik 0-20 location. The arenaceous depocentre is just southeast of the kipnik 0-20 location. The net sand percentage (see Figures 25 and 32 ) decreases noticeably toward and within the Kugmallit Trough. In the Parsons Lake area, nearly all the non-marine sediments are 75 percent or more sandstone, whereas net sand percentages in Ikhil I-37 and in Kipnik 0-20 are 63 and 66 percent respectively. This change in the abundances of sand substantiates the claim that the braided stream types graded basinward from the sandstone-rich, proximal 


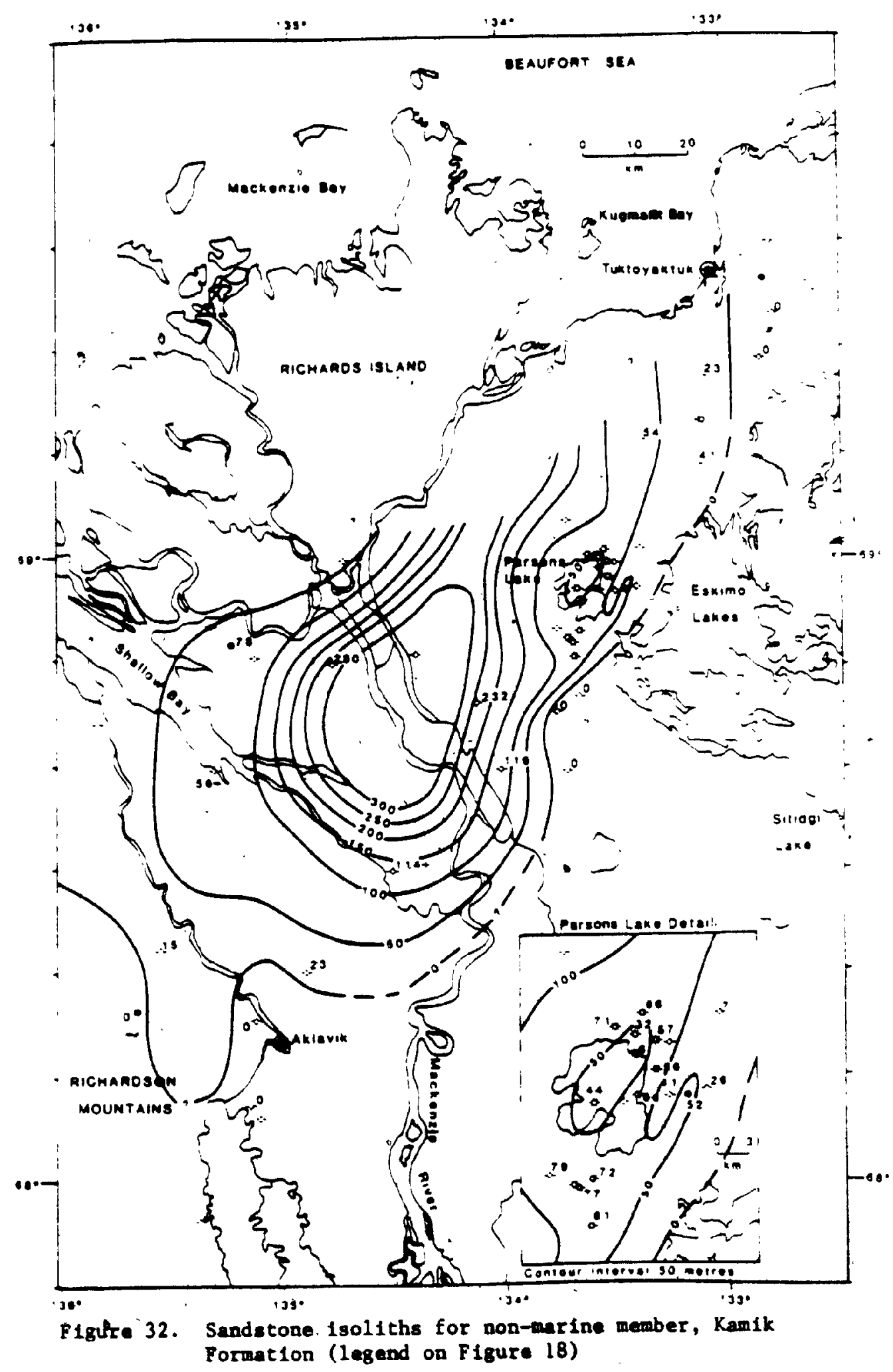


Bijou-Creek type into the "muddy" South Saskatchewan type of braid plain deposition.

Figure 33 is the sand isolith map for the transitional member. Sandstone thicknesses again mimic, to a large degree, . the isopach for the member. The sandiest section of 142 metres was encountered at Ikhil I-37. The arenaceous depocentre. is to the south and the west of the Ikhil I-37 location. Net sandstone percent is significantly less for the transitional member than in the underlying non-marine member. A noteworth deviation of isolith contour patterns from the isopach of the $\checkmark$ member is in the Shallow Bay region. Based on information from Unak B-11 and Kipnik 0-20 wells (see Figure 6), sandstone appears to decrease in abundance to. the northwest, indicating more muddy marine deposition that direction.

Figure 34 is the sand isolith for the marine member. Sand deposition was dominantly in the form of barrier islands/bars. The high control area of Parsons Lake reflects this depositional style. Over the rest of the subsurface, control is so limited that sand patterns can not be accurately discerned and generalized contouring of data is necessitated. The thickest sand section of 75 metres accurs in the Ikhil I-37 well. The arenaceous depocentre lies just to the southwest of the Ikhil I37 location. Net sand percentages are the lowest of any Kamik Formation member. 


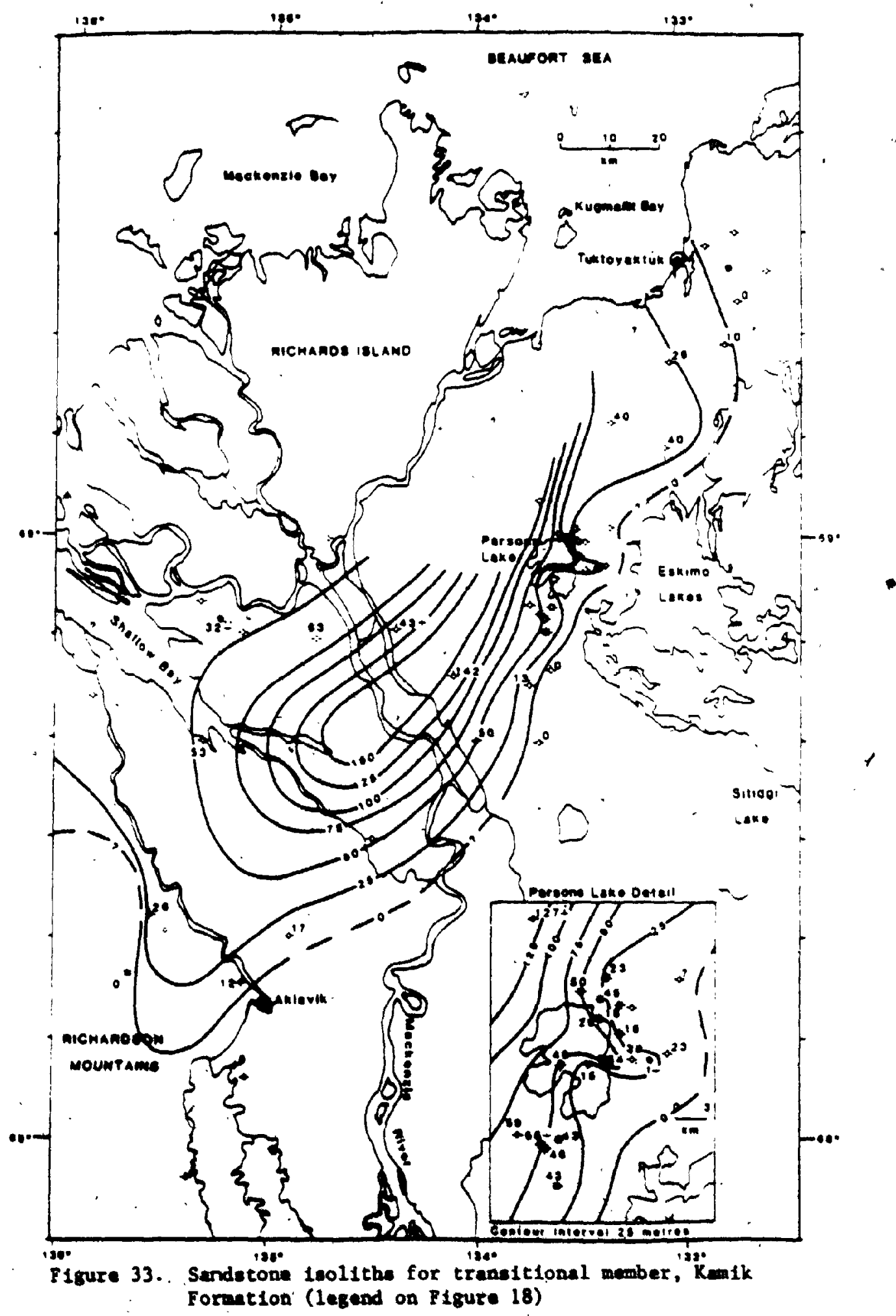




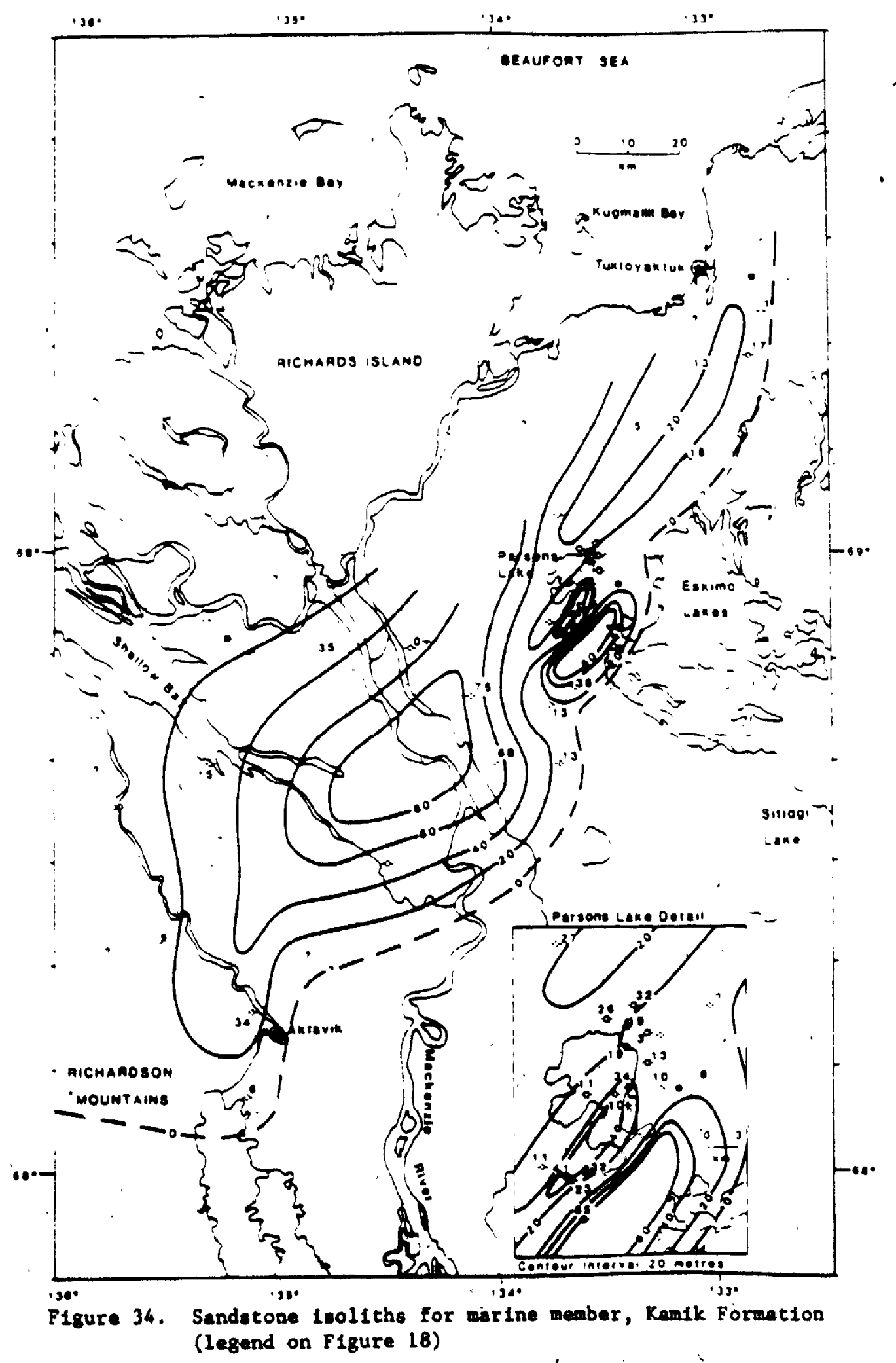


6. DIAGENBSIS

Diagenetic "changes affecting the sandstones of the Parsons Group are mechanical and chemical compaction, 'cementation, dissolution of sillcates and carbonates and the authigenic formation of pore-filling clays.

The excess of free energy which provides the driving force for diagenesis is caused by (Berner, 1980):

- 1. thermodynamically unstable minerals and mineraloids such as aragonite, opaline silica, volcanic glass, semi-amorphous clay minerals - all less stable than corresponding authigenic tinerals.

2. diagenetic change in pore water composition.

Authigenic precipitates may be derived from the dissolution of minerals within the sediment (diagenétic redistribution), or from outside. For quartzose sandstones, the bulk df excess free energy can only be brought about by a diagenetic change in the pore waters " Therefore chemlcal evolution of pore waters with burial depth will control the diagenetic sequence in such sands. The dewatering of interbedded, adjacent or subjacent shales may be the dominant process affecting the kind and amount of waters involved in the dlagenes ls of sandstones.

\subsection{Compaction}

$1 ?$

Although the sandstones studled have diagenetically watured 
beyond initial mechanical compaction, some early mechanical compaction effects can be observed. Petrographic studies also Indicate that although some mechanical compaction has occurred, especially in the finer grained sandscones, most of the cement is allogenic, and the "pressure solution" visible is a product of impinging silica overgrowths (see silica cement, section 6.3 and Plate 68).

The difficulty in differentiating between detrital quartz cores and syntaxial quartz overgrowths in the sandstones studied prevents any accurate evaluation of grain proximity, but the few samples where monocrystalline quartz grains show "dust lines" indicate a relatively low packing proximity due to the presence of early silica cement (Plate 6g).

\subsection{Cementation}

The precipitation of chemical cements is the most important diagenetic event affecting the reservoir potential of the Parsons Group sandstones. Three major cement types occur in the specimens studiè: silica, calcite and authigenic clays. Siderite, pyrite and iron oxide cement occur locally, in minor anounts .

\subsection{Silles Cerent}

Silica ts the most common and abundant cement in the specimens sudied (see Plates 6f,8 and h). As discussed earlier, accurate estimation of amounc of silica cement is not possible due to the difficulty in discriminating between detrital quartz 
and authigentc silica overgrowths. Estinations of silica cement proportions based on the quantity of visible overgrowth crystal. faces, recognition of overgrowths through variations in scrain phenomenon and inclusions and "dust lines"; when present, range from close to zero to near 25 percent. SEM examination shows the presence of sllica overgrowths in the Parsons Group rocks and its effect on porosity (see Plates $7 a, b$ and $c$ ).

The source of the silica may be:

1. sillca derived from shales, from both initial waters at the time of burial and the smectite to illite transformation occurring at depth.

$$
\mathrm{K}^{+}+\text {Smectite } \leftrightharpoons \mathrm{Illlte}+\text { Chlorite }+ \text { Quartz }+\mathrm{H}^{+}
$$

2. Dissolution of feldspars and quartz

3. Pressure solution

4. Meteoric waters.

Petrographic work suggests that pressure solution is not a major source for diagenetic quartz but merely serves to redistribute sillca from zones of high lithostatic pressures to zones of lower hydrostatic pressures within the rock itself (see Plate 68). Silica in aesogenetic and late cothenting phases may be derfved frov the intrastratal dissolution of quartzose rocks (see Plate 1): Diseolution of feldepars and quartz is not 
considered adequate to supply enough sllica to form the amount of overgrowths in the sandstones examined. Eogenetic (surface influenced-early) and mesogenetic (below surface influences) silica overgrowths were therefore most likely derived either from circulating meteoric waters and/or from silica-bearing waters expelled from shales during burial, and probably deposited throughout the diagenetic history. Intrastratal. dissolution may have contributed significant, volumes of silica at depth.

\subsection{Calcite Cenent}

Pore-filling calcite is present in at least minor quantities in most sandstones., but rarely in amounts more than 3 percent. Locally, calcite can constitute the dominant cement but such occurrences are rare. Calcite occurs as a fine mosaic of subequant clear crystals or in association with dark, probably illice-based clays (see plates $7 d$ and e). In samples with abundant calcite, the cement is coarse and poikilotopic, and is accompanied by partial to total replacement of detrital grains by calcite) (see plate 7f). In most samples, however. sparse calcite is scattered throughout the sample (see plate 7g) apparently remnant after a major phase of mesogenetic dissolution. Most textural relationships observed in thin section suggest that calcite cementation succeeded the early silica cement.

The proportions of calcite and silica cement maybe attributed to the chenical instabllity of calcite. Quartz solubility is sensitive to pH only over 9, and is an order of 
magnitude less than that af calcite in sea water quartz remains less soluble than calcite during a large range of conditions associated with diagenesis (Hayes, 1979).

\subsection{Authlgenic Clay Cesent}

Petrographic study, scanning electron mictoscopy and $x_{-}-a^{y}$ examination (see Appendix 3) reveal the presence of cidy minerals of two main groups - illite-dominated and kaulinite.

\subsubsection{Illite}

Illite-based authigenic clays àre shown from X-ray examination, to be a mixed-layer illite (dominated) - montmorillonite. Illite is the dominant authigenic clay, present in aloost all samples studied in quantities up to 27 percent. The illite occurs as:

1. Isplated or interconnected pore fillings. It may cotally fill the pore space or be randomly scattered through an incompletely filled pore. Plate 7 h shows this form of illite clay in thin section. Investigation of this form of pore-filing illite-montmorilionite by scanning electron microscopy reveals many morphologies, most probably related to slight variations in composition and diagenetic history. Plates 8a, and b show illite-mortmorillonite as partial to total pore-fillings. These same plates also show clay morphologtes simllar to those of illite/illite-montmorillonite as presented by Wilson and Pittman (1977). Place 8c exhlbics a very tghtly packed laminaced, 
pore-filling authigenic clay. Although such morphologies resemble detrital chlorite (Wilson and Pittman, 1977, p.18), no detrital clay is recognized in thin section and no chlorite was detected by X-ray examination. The irregular flakes and lathlike projections characteristic of illite-dominated authigenic clay can be spotted upon closer examination. Morphologically. less characteristic illite/illice-montmorillonite combinations are displayed in Plate 8d. Commonly, this form of illitenontmorillonite clay is present in large enough quantity to fill all or must of the porosity (see Plate $8 \mathrm{e}$ ).

2. Thin pore linings, usually with associated congested pore throats in finer grained rucks. Plates 7 e and $8 \mathrm{f}$ exhibit this for of illite distribution. Scanning electron microscopy reveals that this form of ildite is similar to the itregular flakes and delicate growth habits depicted in authigenic illite and illite/montmorillonite clays in Wilson and Pittman (1977). Plates $8 \mathrm{~g}$ and $8 \mathrm{~h}$ show this form of clay at two different magnifications in two different rocks.

3. Thick pore linings, usually associated with random distribution of illite throughout the sample, pore throat congestion and abundant bridging of pore space (Plates 9a and 9b). It may be a coarser development of form 2. An illite morphology is recognitable in SEM fhotomicrographs (Plate 9c). 


\subsubsection{Kaolinite}

According to Hoffman and Hower (1979, Figure 13), dickite is the higher temperature equivalent of kaolinite, forming at temperatures greater than approximately $100^{\circ} \mathrm{C}$. The Parsons Group rocks studied with thin section and SEM are presently at temperatures below $100^{\circ} \mathrm{C}$, suggesting that kaolinite should be the dominant phase present. X-ray examination of some specimens concurs with the above prognosis (Appendix 3). Kaolinite occurs mainly as a pore-filling authigenic clay in quantities up to 7 percent.' In thin section it is recognizgble as stacked plates or books with" a sometimes recognizable pseudohexagonal crystal habit ( Plate 9d). Kaolinite may also exhibit an interlocking very fine-grained mosaic habit difficult to distinguish from chert in thin section. Scanning electron microscopy reveals four forms of kaolinite. These are:

1. Scattered pore-filling stacked pseudohexagonal platelets aligned parallel to each other ( Plate 9e). Most common form.

2. Vermicular growth, extending the length of the pore as a booklet-type morphology (see plate $9 \mathrm{f}$ ).

3. Pseudohexagonal plates coating quartz grains (see Plate 9g).

4. Least common, pore-filling stacked platelets with poorly defined, irregular Plate edges (see Plate 9h). This käolinite may have suffered sqme marginal corrosion. 
Individual kaolinice plates range from 3 to 12 um in length and 0.3 to 2.0 um in thickness.

\subsubsection{Other authigenic clays}

No chlorite was recognized in thin sections but very minor amounts of the mineral were detected in $X$-ray examination (see Appendix 3). Minor authigenic muscovite was recognized in trace quantities in a few of the samples studied.

\subsection{Hematite Cement}

Although absent from the majority of specimens examed, red to reddish-brown hematite cement may be present in minor amounts .

\subsection{Siderite Cement}

Siderite occurs sporadically throughout the Parsons Group sands as scatrered finely crystalline dark yellow-brown "beaded" flattened rhombs. Not more than 3 percent siderite is observed in the rocks studied, but Schmidt and McDonald (1979) suggest that siderite locally is a dominant cement in the Parsons Group. This disparity is probably a function of different sample locations.

Mineralogical associations indicate the siderite has undergone significant mesogenetic dissolution.

\subsection{Pyrite Cenent}

Pyrite, the rarest cement, occurs either in a disseminated 
lath-like pore-fllling form (Plate 10a) or as patches in a few samples. Plate $10 \mathrm{~b}$ shows pyrite cement replacing quartz in a typical occurrence of patchy pyrite. Finely crystalline porefilling disseminated pyrite is also present ( Plate 10c).

\subsection{Glauconite}

Green glauconite occurs as irregular fine grains usually. in trace amounts throughout the Martin Creek and McGuire Formations. and thhe upper marine rocks of the Kamik Formation.

\subsection{Replacement}

Carbonate partially replaces both feldspar and quartz grains in the rocks studied. Siderite or calcite may partially replace plagioclase or potassic feldspar. This phenomenon occurs sporadically within the stratigraphic section, indicating the variability of such controls as feldspar composition and local chemical conditions.

Defeldspathization is sometimes associated with the formation of illite (-montmorillonite?). This relationship is shown in plates $9 a$ and $10 d$ and in the communality chart of Figure 35 (section 6.14). Possible reactions are (after Hutcheon, 1981):

$$
\underset{\mathrm{K} \text {-spar }}{3 \mathrm{KAlSi}_{3} \mathrm{O}_{8}}+2 \mathrm{H}^{+} \leftrightharpoons \mathrm{KAl}_{2} \mathrm{AlSi}_{3} \mathrm{O}_{10}\left(\mathrm{OH}_{2}\right)_{2}+6 \mathrm{SiO}_{2}+2 \mathrm{~K}^{+}
$$

$3 \mathrm{NaAlSi}_{3} \mathrm{O}_{8}+2 \mathrm{H}^{+}+\mathrm{K}^{+} \leftrightharpoons \mathrm{KAl}_{2} \mathrm{AlSi}_{3} \mathrm{O}_{10}(\mathrm{OH})_{2}+6 \mathrm{SiO}_{2}+3 \mathrm{Na}^{+}$
Albite
Illite

Abundant carbonate cement is associated with minor to 
extreme quartz corrosion and replacement (Plates 7e and f). Previous replacement of quartz by carbonate is inferred in a number of samples in which corroded quartz grains (Plate 7e) are seen but carbonate has been mostly dissolved.

As illustrated in plate 10b, pyrice locally replaces quartz, and most likely any other detrital fragment which it surrounds.

\subsection{Dissolution}

Dissolution of detrical fragments and authigenic cements plays a major role in the diagenetic sequence, creating significant volumes of secondary porosity in the process. As exhibited in Plates 6e, $10 \mathrm{~d}$ and $10 \mathrm{e}$, abundant intrastratal feldspar dissolution has occured and in at least some specimens is almost complete as evidenced by the sparse feldspar remnants accompanied by oversized, moldic pore spaces.

Mesogenetic dissolution of carbonate cement (both calcite and siderite) is recognizable by the erratic distribution of residual carbonate in the rocks, and the abundant corrosion of quartz grains where carbonate has been totally dissolved. Most porosity observed in thin section is apparently a product of carbonate cement dissolution and is therefore secondary. Plate lof shows isolated remiant carbonate cement. partially dissolved.

Intraparticle porosity is commonly observed in chert clasts. 
(Plates $6 c$ and $d$ ) and may reflect either partial dissolution of chert or the intrastratal dissolution of residual carbonate within the chert.

Leaching of feldspars is apparently a result of both acid diagenetic solutions (Almon 1981) and (for Ca-poor feldspars) solutions with high $\mathrm{pH}$ and $\mathrm{rich}$ in $\mathrm{Ca}^{2+}$ and $\mathrm{C}_{2} \mathrm{O}_{2}$ (Dapples, 1967, p.106). High pH flulds are undoubtedly responsible as well for dissolution of quartz in the Parson Group strata. According to Schmidt and McDonald (1979), most mesogenetic decarbonatization results from the decarboxylation of organic matter interbedded with the sandstone or in strata underlying the sandstone. The decarboxylation generates $\mathrm{CO}_{2}$ combined with water produces carbonic acid capable of dissolving the carbonate. Other positole causes for decarbonatization are physico-chemical gradiencs at the boundaries of geopressure zones, the release of water from clay minerals and the generation of hydrogen sulphide (Schmidt and McDonald, 1979 , p.198).

\subsection{Paragenesis of Cements and Authigenic Minerals}

Petrographic studies reveal spatial relationships of the diagenetic features and components from which a sequence of diagenetic events is proposed. When necessary, diagenetic theory and published examples are used to substantiate conclusions.

of the minor authigenic minerals, glauconite and pyrite are thought to be mainly eogenetic. From the general ferric to 
ferrous iron proportions in glauconite, it. is deduced that glauconite is formed under moderately reducing conditions, probably associated with the action of sulphate-reducing bacterla on decaying organisms (Deer, Howle and Zussman, 1966). Pyrite is thought to form under reducing, neutral to weakly acidic conditions during early diagenesis (Wolf and Chilingarian, 1976). While most of the pyrite may be eogenetic , it is possible that mesogenetic pyrite is also present (Plate 10c). For late pyrite to form, the sulphur ions have to be held in some sulphur complex (sulphate etc.) until reducing conditions induce pyrite formation.

Petrographic study of the major ceinents suggests a sequence of authigenic minerals, reflecting in whole or in part a diagenetic history which may or may not be completely recorded. The following observations are pertinent to the Parsons Group rocks.

1. Syntaxial silica overgrowth was the first, and is the most pervasive of all cements. plates $7 \mathrm{a}, 7 \mathrm{~b}, 7 \mathrm{c}, 8 \mathrm{~b}, 8 \mathrm{~d}, 8 \mathrm{~d}, 8 \mathrm{~g}, 9 \mathrm{c}, 9 \mathrm{e}, 9 \mathrm{f}, 10 \mathrm{~g}$ and $10 \mathrm{~h}$ show that kaolinite, illite (-montiorillonite), and carbonate, occur after the quartz, deduced to be an early to intermediaté (eogenetic to mesogenetic) diagenetic phenomenon. This observation concurs with that of Schmidt and McDonald (1979). 
2. Carbonatization (including cements and replacement) is the next major diagenetic event, occurring alone or accompanied by authigenic clay cements (Plates $10 \mathrm{~d}$ and 10e). Carbonatization is thought by Schmidt and McDonald (1979, p.196) to be an internediate diagenetic stage, but thelr study, of secondary porosity in the Parsons Group rocks, showed that siderlte, was at least in part, an eogenetic mineral.

3. Associated with carbonatization is the corrosion of quartz grains, and most likely the corrosion of feldspars since the high pH fluids that were responsible for silica dissolution should also be capable of destroying the feldspar lattice (Dapples, 1967, p.106).

4. In cases where decarbonatization does not occur and all pore space is filled, the diagenetic process terminates at this stage.

5. The process of decarbonatization (carbonate dissolution) may create abundant pore space, allowing further diagenesis. Abundant authigenic llite-rich mixed layer clay and kaolinite are then precipitated in these secondary pore spaces. Coexistence of flite and kaolinite is common (Plate lla). suggesting overlapping conditions and times of precipitation.

6. A noticeable quantity of silica cement was deposited after decarbonatization, as indicated by the uncorroded crystalline silica overgrowths present in places where dissolution of 
carbonate cement can be proven (assuming that corrosion of quartz is invariably associated with carbonate precipitation). Plates $6 \mathrm{~h}$ and $11 \mathrm{~b}$ show rocks with high secondary porosity and pristine quartz overgrowths after carbonate dissolution. Plate $11 \mathrm{c}$ shows an authigenic quartz crystal face riddled with kaolinite plates and deep tmpressions of plucked kaolinite booklets. It is likely that these silica overgrowths formed around an already nucleated mesogenentic kaolinite crystal. *

7. After decarbonatization, further physical and chemical compaction and feldspar dissolution may continue.

\subsection{Porosity}

Original primary porosities in the lsands studled were probably in the range of 40 percent (Pryor, 1968). Present porosities range from 0 to 25 percent and are virtually all of secondary origin, as determined from the criteria of Schmidt and McDonald (1979). Plates $7 b, 7 c, 7 f, 8 b$ and $8 c$ show examples of the diagenetic loss of primary porosity accomplished by a conbination of compaction and cementation processes.

Dissolution of cements - especially carbonate - and feldspars created secondary porosity (Plates $11 \mathrm{~b}$ and d). Examples of high porosities through extreme and thorough dissolution, most likely of carbonate cement, is shown in Plate $11 \mathrm{~b}$. Most samples exalined demonatrate secondary porosities reduced by silica and clay cements (Plates 7b, 8b,9e; 10a and 11e). Pore and throat 
sizes thus reduced result in a concomitant rediction of permeability. The high surface area typlcal of illite clay growth (W1lson and Pittman, 1977) ts associated with abundant microporosity which wil, in all likellhood, be totally ineffective an hydrocarbon reservolr due to the small pore dianeters present. Microporosity associated with kaolinite is Intercryatalline in the form of interbooklet pores (Plate $11 \mathrm{f}$ ). The wicroporosity associated with kaolinite crystals is coarser than that which 18 present in illite crystals of the same size, and as such is probably related to higher permeability.

\subsection{Diagenetic Asaciation}

Observations of warked changes in the proportions of cements, feldspar and porosity observed over short vertical distances supported a study of associations amongst these features. Figure 35 is a communality"chart of the variable diagenetic features based on closely spaced samples in the Parsons N-10 well. Associations revealed by Figure 35 are divided simply Lita weak and strong, and are presented in schematic form in Figure 36.

Many associations shown in Figure 35, such as the association between porosity and the degree of dissolution, and between porosity and silica overgrowths are as expected, but some strong associations apparent in figure $35^{\circ}$ could not have been demonatrated whout detalled petrogaphlc analysis. These Include: 


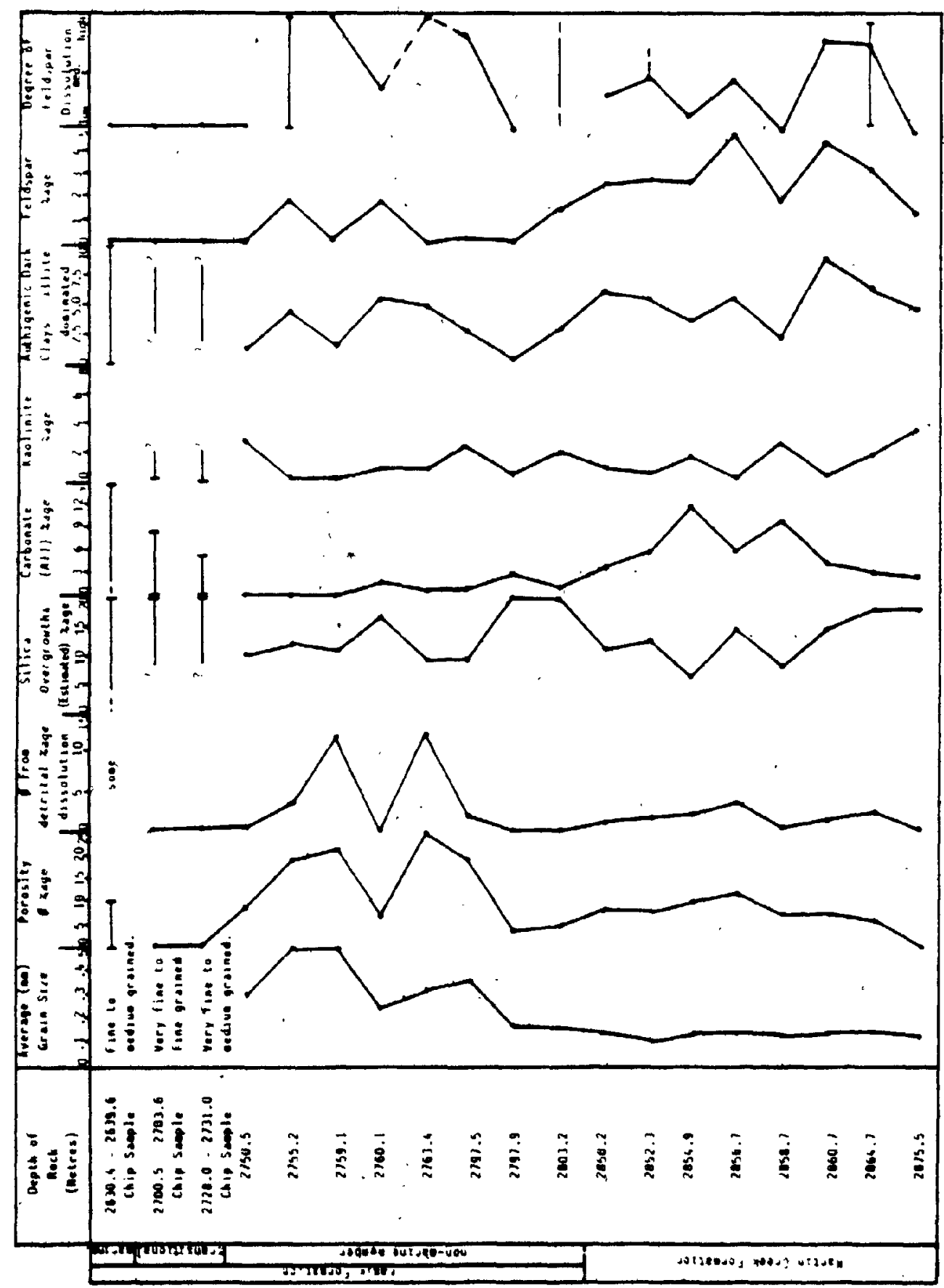

告 
1. Porosity variations are related to grain size.

2. Dissolution porosity (irregular, moldic porosity) can be directly related to the degree of feldspar dtssolution

3. The quantity of illite (-montmorillonite) clay, observed to be authigenic in the nost part, is proportional to the quantity of feldspar. Apparently, an abundance of residual feldspar indicatęs greater linitial quantities of detrital feldspar and the illite present is, to some degree, a dissolution product of feldspar.

The most perplexing, yet economically important association exposed by Figure 35, is the direct relationstip between porosity and grain size. Figure 37 expresses this association for all the samples studied. Previous investigators have related variations in diagenetic features to permeability differences. Wolf and Chilingarian (1976, p.173) stated that a permeable coarse-grained sandstone will be cemented faster than a finer-gralned rock, if all other conditions are equal. Melon (1964) reached a similar conclusion in surmising. that the extent of calcite and silicate cements is dependent upon the the pore size (packing), which is slightly greater in coarsergrained rocks. In the Parsong Group, a greater permeability should then be associated with the coarser sandstones (see Table 1).

During and after eogenetic cementation by silica, the 
relatively higher permeabilities of coarser Parsons Group rocks probably increased slightly with respect' to finer-grained rocks. The relative porosities of coarse and fine-grained sandstones would remain unchanged. Subsequent mesogenetic cementation by carbonate would have been enhanced in the more permeable, coarser sandstones compared to that in the less permeable finergrained sandstones. On a large scale, the process would have been self-limiting. Where carbonate cement was present, further porosicy reduction through the pressure - solution of quartz or precipitation of allogenic silica would have been impeded or prevented, but where the carbonate cement is lacking, silica cementation would proceed according to the prevailing temperature, pressure and fluid conditions. The expected results of such texture-controlled processes would be tightly silica-cemented finer-grained rocks and coarser-grained rocks with a mixture of carbonate and silica cements. Subsequent dissolution of carbonate, while not affecting significantly the diagenetic state of the finer-grained sandstones, would result in abundant secondary porosity in coarser-grained sandstones.

"Such a model is supported by the association, albeit weak, of grain size and the amount of silica cementation. A stronger association may exist, but is not demonstrable because of difficulties mentioned earlier in accurate determination of the proportion of silica overgrowths. Figure 36 is a diagenetic association chart based on Figure 35, expressing the associations present as related to porosity. Such a chart 


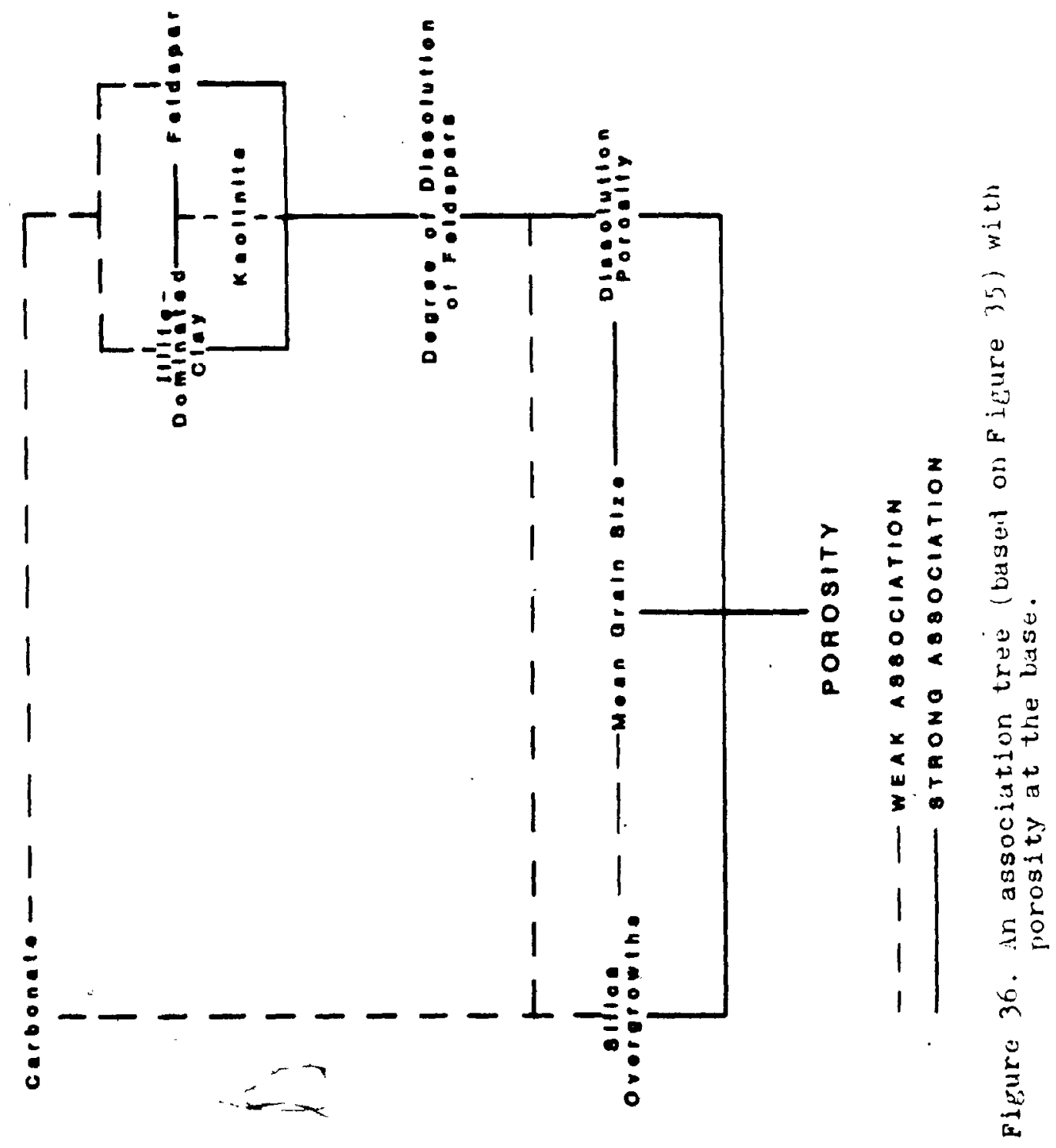


clearly shows the dependence of porosity on silica overgrowths, grain size and feldspar dissolution. Since the chart is based only upon observational measurements representing a specific time late in the diagenetic history, it does not reveal the past importance, nor the dissolution history of the carbonate cements. The carbonate proportions are those remaining after mesogenetic dissolution, showing an erratic distribution of a volumetrically unimportant mineral.

\section{DIAGENESIS, AND THE PURSUIT OF POROSITY}

\subsection{Predicting Reservoir Porosity}

The previous section outlined the apparent correlation between grain size, Feldspar content and porosity, allowing a determination of reservoir quality based upon a sy thes is of petrographic characteristics, including diagenetic features.

Assuming the described diagenetic phenomena are consistent throughout the subsurface, the sandstones of the non-marine member of the Kamik Formation should have the greatest porosity, being the coarsest unit in the Parsons Group. Winn et al. (1984) show that the coarser-grained non-marine sands of the frontier sandstone in Wyoming have a higher porosity than finer-grained sands of the same unit. Porosity should generally lessen in the finer-grained transitional member sandstones and deteriorate further in the still finer-grained marine member. Such a relationship is suggested by the stratigraphically controlled porosity variations exhlbited in'Figure 37. Large positive 


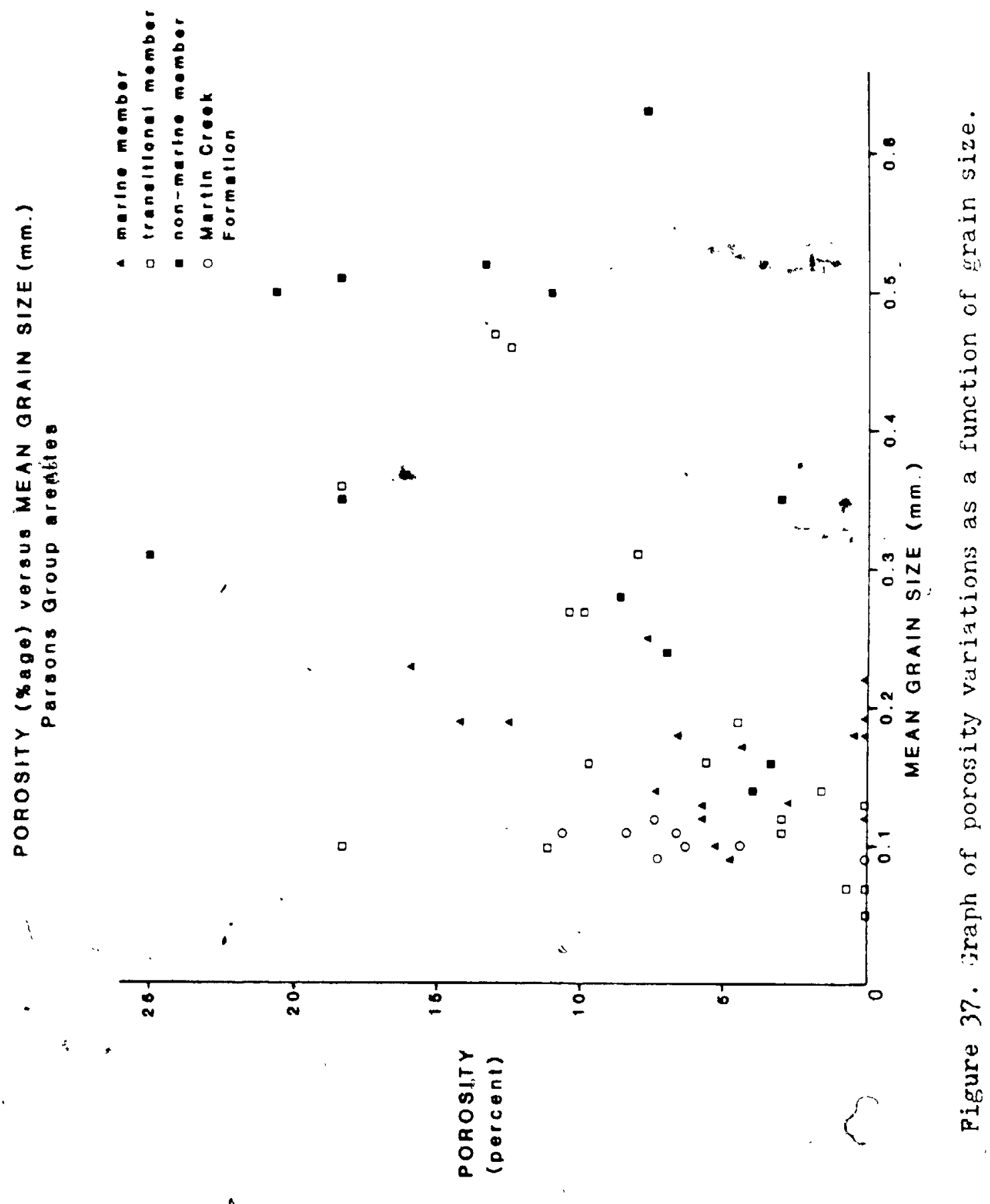


deviations from a linear porosity-grain size relationship probably reflect abundant feldspar dissolution porosity.

Martin Creek sandstpnes are typically fine-grained, well sorted and consistently contain more detrital feldspar than any other sandstone group examined. Empirical relationships suggest a significantly greater importance of grain size relative to Eeldspar dissolution (limited amount of moldic porosity), in the generation of secondary porosity. Potential subsurface porosities of the Martin Creek sandstones are only slightly greater than those of the transitional member of the Kamik.

\subsection{Diagenetic Facies and Depth}

The diagenetic mineral assemblages in any rock are a function of original mineralogy, time, geothermal gradient, depth and the nature of the diagenetic waters. Schmidt and McDonald (1979) have outlined these controls and the effects of these controls on the diagenetic cycle. They concluded that sandstones progress from the immature to supermature diagenetic stages with each intermediate phase characterized by certain diagenetic phenomena and resultant porosities (Figure 38). In any system of one age, exhibiting uniform mineralogical characteristics, and deposiced in a basin with a relatively invariant geothermal gradient, diagenetic assemblages should be controlled solely by depth and the nature of the diagenetic waters. 
4

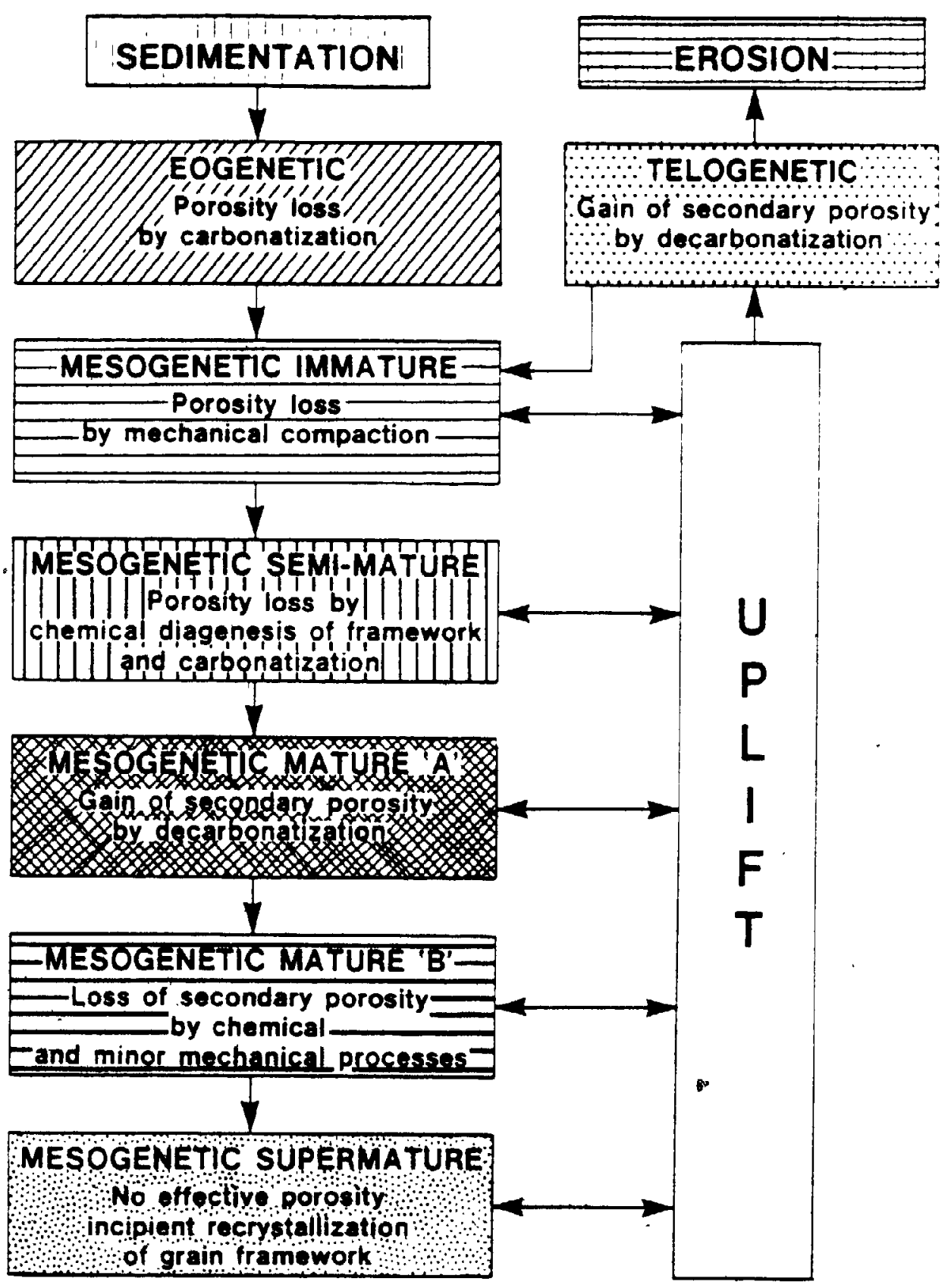

Figure 38. Diagenetic evolution (cycle) of sandstones (from schmidt and ic Jonald, 1979, figure 27 ). 
The Parsons Group conforms to the above conditions, with most of the basin presently possessing a geothermal gradient ranging from $2.7^{\circ} \mathrm{C} / 100 \mathrm{~m}$ to $3.2^{\circ} \mathrm{C} / 100 \mathrm{~m}$ (bottom hole temperatures from logs). Slightly higher and lower geothermal gradients exist very near the Tuktoyaktuk Eault-Flexure Zone, but are local in extent. If the effects of diagenetic waters are disregarded diagenetic facies within the Parsons Group strata should be approximately a function of depth. Table 3 is $\Rightarrow$ simplified categorization of the diagenetic stages represent in the wells studied based on the Schmidt and McDonald (1979, Figure 27) scheme. From this table the approximate depth, location and extent of the Mature $A$ zone can be estimated. Extrapolation of associated diagenetic zones (Figure 38) as a Cfunction of real depth in the Kugmallit Trough, provides an approximation of the depths of these diagenetic zones in relationship to the Parsons Group. Figure 39 is a schematic maximum porosity plot redrawn after Schmidt and McDonald (1979, Figure 12) for the Parsons Group sandstones based on the depthdiagenetic-zone relationship. Based on Table 3 , the transition from the semi-mature zone to the mature zone occurs at a depth of approximately $2.5 \mathrm{kilometers.} \mathrm{Secondary} \mathrm{porosity} \mathrm{associated}$ with the mature zone diminishes to near zero at about 7 kilometers depth. Choosing, arbitrarily, a 20 percent maximum porosity cut-off, the deepest potential reservoir is most likely above 6 kilometers. Figure 40 is a synthesis of Figures 3 (the generalized structural contour on the tôp of the Parsons Group) and 39, showing, qualitatively, relative reservoir potential at 


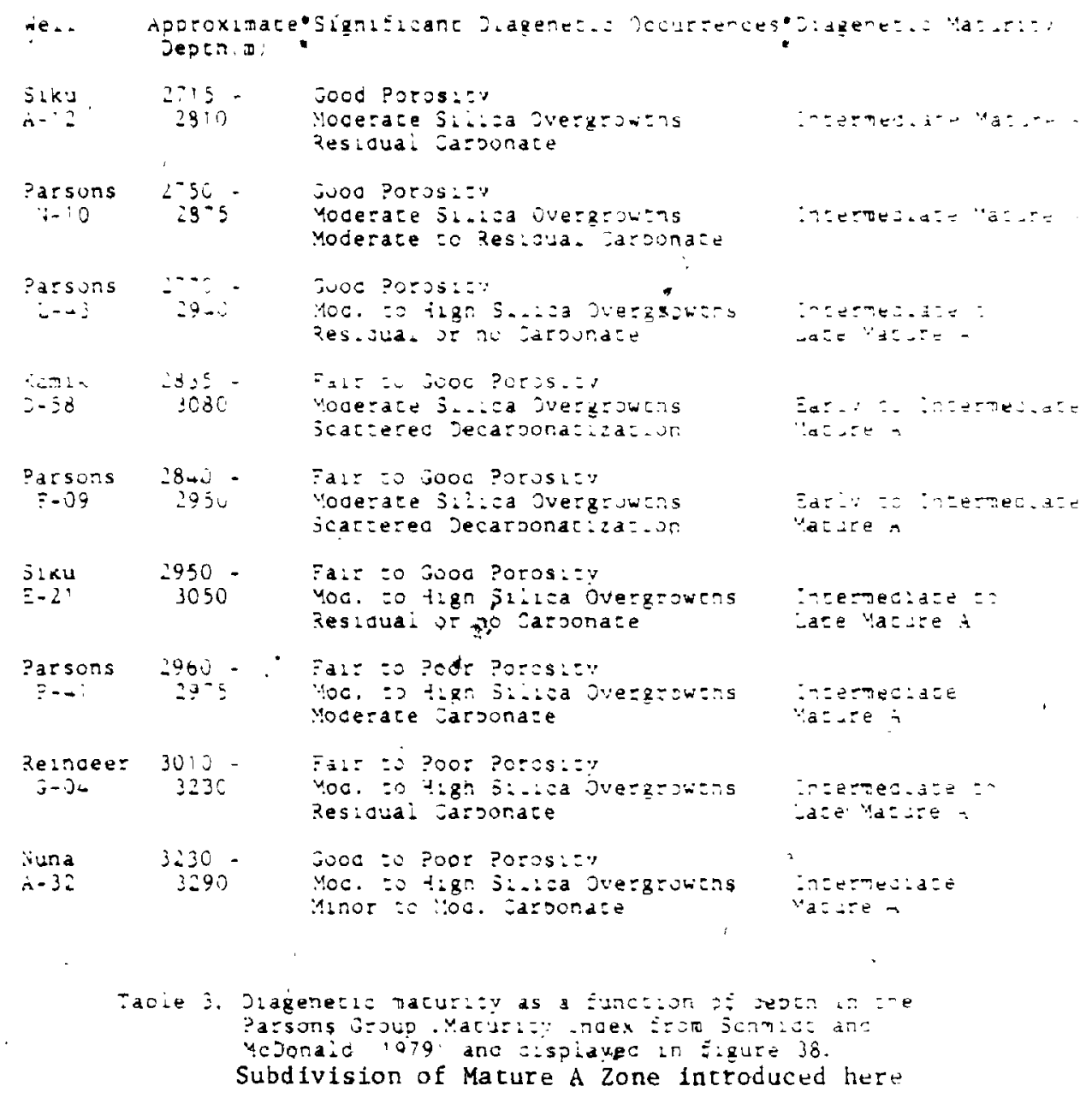




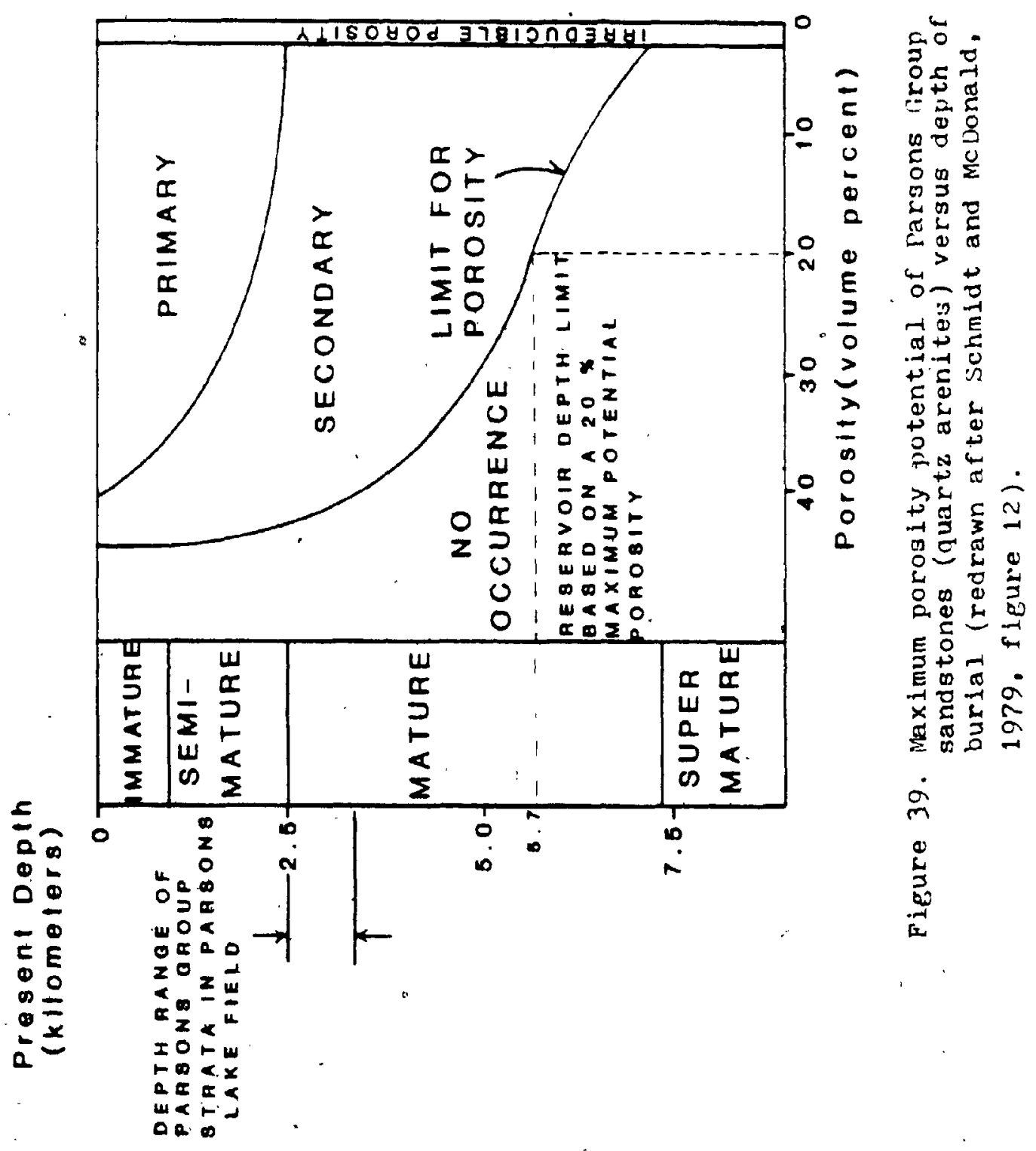




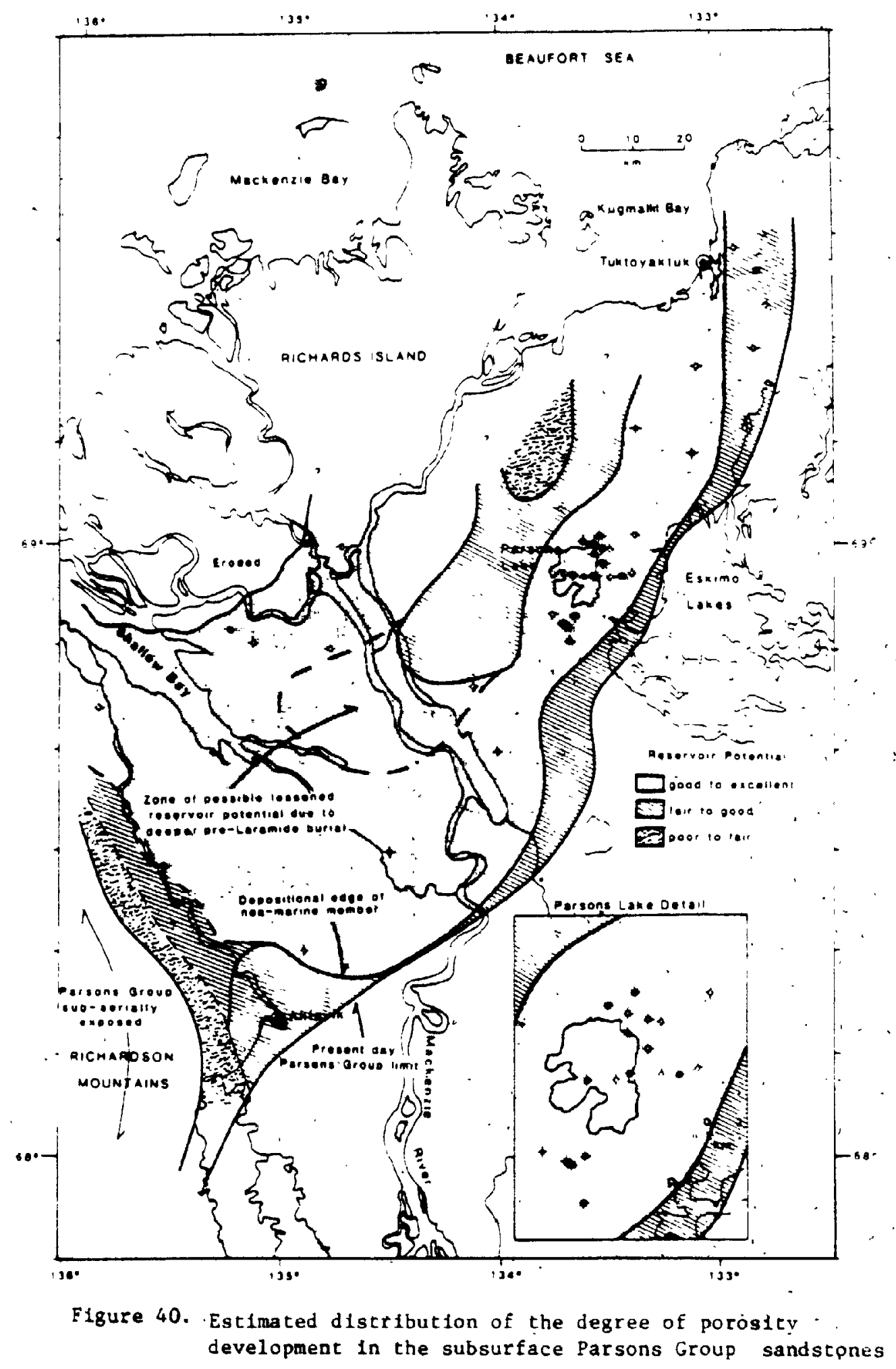


different depths. Contour trends from Figure 3 suggest limited reservoir potential to the north of Siku C-55, and west of Parsons Lake in the zone of thickest Parsons Group. Near-surface Parsons Group rocks proximal to the Rlchardson Mountains likely have a reduced reservoir potential due to chemical and/or biochemical degradation of any hyrocarbons present. Parsons Group sands in the remainder of the basin have fair to excellent reservoir potential. The zone of decreased potential near the Eskimo Lakes Arch correlates with the depositional edge of the best reservoir - the non-marine member. The Parsons Group isopach (Figure 18) reflects a more extensive depocentre than the structure map (Figure 3) would suggest. Apparently, the western half of the Kugmallit. Trough was uplifted in the most part, probably during the Laramide orogenic event. If uplift preceded the burial of Parson Group strata to depths where porosity was significantly reduced (as in the eastern Kugmallit Trough where late mature or supermature diagenetic facies probably exist), then porosity potential will be as outlined in Figure 40. This is likely the case, as the subsidence plot constructed by Langhus (1980, Figure 7) suggests that burial in the eastern Kugmallit Trough continued throughout the Tertiary to the present-day deepest point. In the less-likely case of subsidence being all pre-Laramide, western Kugmallit Trough strata would have the same reduction in porosity thought to exist in the eastern Trough. 


\section{SURAMRY AND COMCLUS IOAS}

\subsection{Sumary}

This study has used avallable geophysical, petrographic, and biostratigraphic information from 50 wells to develop and present a better understanding of the sedimentary petrology and stratigraphy of the Parsons Group rocks. Despite the inherent limitations of such a study, the understanding and extrapolation of depositional patterns and environments in the Parsons lake area to areas with less subsurface control allow a general, but geologically reasonable, interpretation for the whole basin.

An easily identifiable, progressively transgressive, basin-wide vertical succession of lithologies is recognized in the Kamik Formation, and permits a subdivision into three lithostratigraphic units. Such a division allows for a more complete understanding of sedimentological and tectonic histories of the best reservoir unit in this area of the subsurface.

The Parsons Group units are probably somewhat diachronous, but the sparse, vague and sometimes ambiguous biostratigraphic control does not permit an evaluation of the degree of diachronism. Stratigraphic interpretations and depositional patterns suggest that unit boundaries are only slightly diachronous, and reflect inor tectonic events which greatly affected basin-wide sedimentation patterns. 


\subsection{Conclusions}

Petrological and stratigraphic studies on the subsurface Parsons Group have led to these conclusons.

a. Parsons Group sandstones studied are mostly quartz arenites, and are usually texturally supermature.

b. The Martin Creek Formation is richer in feldspar than sands in the Kamik Formation. This difference can be attributed, at least in part, to feldspar dissolution in the Kamik Formation.

c. The Kamik Formation can be divided into three informal members mappable over the wole subsurface extent of the Kamik Formation.

d. There are distinct differences in grain size among the four sandstone-bearing units-Martin Creek Formation and the nonmarine, transitional, and marine members of the Kamik Formation. The non-marine member includes the coarsest sandstones, whereas the marine member and Martin Creek Formation are characterized by finer-grained sandstones.

e. Chert content is apparently a function of grain size. The coarser-grained lower Kamik sands contain more chert than the overlying finer-grained rocks.

f. The Kamik Formation shows a succession of depositional environments which change from high-energy fluvial at the base to offshore marine at the top. The changing environments of depostion closely coincide with the contacts between the proposed informal members. 
8. Interpretive isopach maps show basin configuration controlled by the Eskimo Lakes Arch, Tununuk and Napoiak Highs, Cache Creek Uplift, and the Canoe Depression, but the degree of influence exerted by these structural features varied through Parsons Group time.

h. Limits of Parsons Group strata onto the Eskimo Lakes Arch are re-interpreted as being controlled more by depositional processes rather than by erosional processes.

i. Fault movement in the Parsons Lake area probably was contemporaneous with Parsons Group deposition.

j. Silica cementation occurs early and is widespread in the sandstones studied.

k. Porosity observed in the Parsons Lake area appears to be mostly secondary.

1. Assoos -observed between secondary porosicy and grain size, feldspar dissolution and moldic porosity, and authigenic illite and the quantity of feldspar appear to be strong.

m. The reservoir characteristics of each sandstone-bearing unit are defined by the response of the textural and mineralogical characteristics of the rocks to the diagenetic influences.

n. The type and quantity of porosity in the Parsons Lake area is closely related to the level of diagenetic maturity, which is related directly to present, day depths of burial. 


\section{RECOMMENDATIONS FOR FURTHER STUDY}

On the basis of this study, the, authour recommends;

a. Further rapping of diagenetic facies in deeper and shallower holes using chip samples. From this, a more accurate depth-controlled diagenetic maturity plot can be constructed.

b. Detailed mapping of individual sand bodies in the Parsons Lake area where control is sufficient to merit such a study. Insights into the environments of deposition should be gained.

c. Detailed documentation of the types and distribution of lithologies in the non-marine member of the Kamik formation. The occurrence and nature of this sandstone unit represents an opportunity to draw analogies from such high-energy subsurface deposits to well-documented models and allow the creation of a subsurface model based mainly on log response.

d. Investigation of the occurrence of stylolites in the Parsons Group sandstones. Stylolites may occur more frequently in deeper buried sandstones, and such intrastratal dissolution of quartz may be a major source of silica during late cementation.

e. Formal introduction of names for the non-marine, transitional, and marine members of the Kamik Formation into the licerature. 
Plate 1

Core, 3909-3912.5 metre interval Ikhil I-37 well. Medium to coarse-grained quartzose sandstone containing shale rip-up clasts with some high angle cross-bedding. Arrows point towards stylolitic horlzons. Braided channel environment, non-marine nember. 


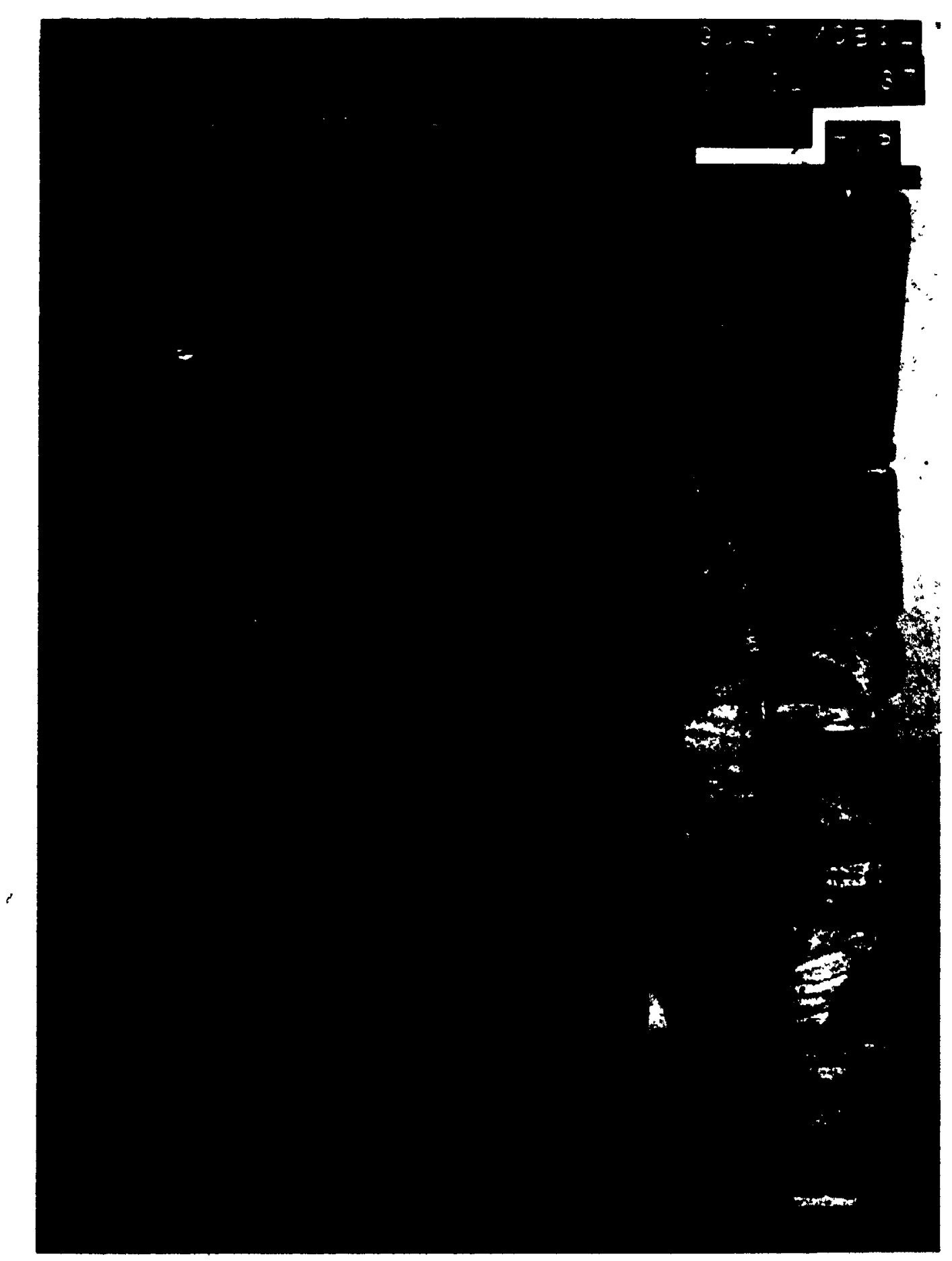


Plate 2

Core, 3041-3045.5 metre interval, Siku E-21 well. Interbedded fine to coarse-grained pebbly sandstones and silty mudstones, representing deposition in a relatively high-energy meandering river environment in the transitional wember. A lower channel bar sandstone may be present at the top of the core, whereas the shaly rock is probably from a natural levee environment. Sandstone in box 3 is most-likery a crevasse-splay deposit. Scale in inches.

3 
Plate 2

\section{$\vdots \therefore \cdots \vdots \vdots \vdots \vdots$}

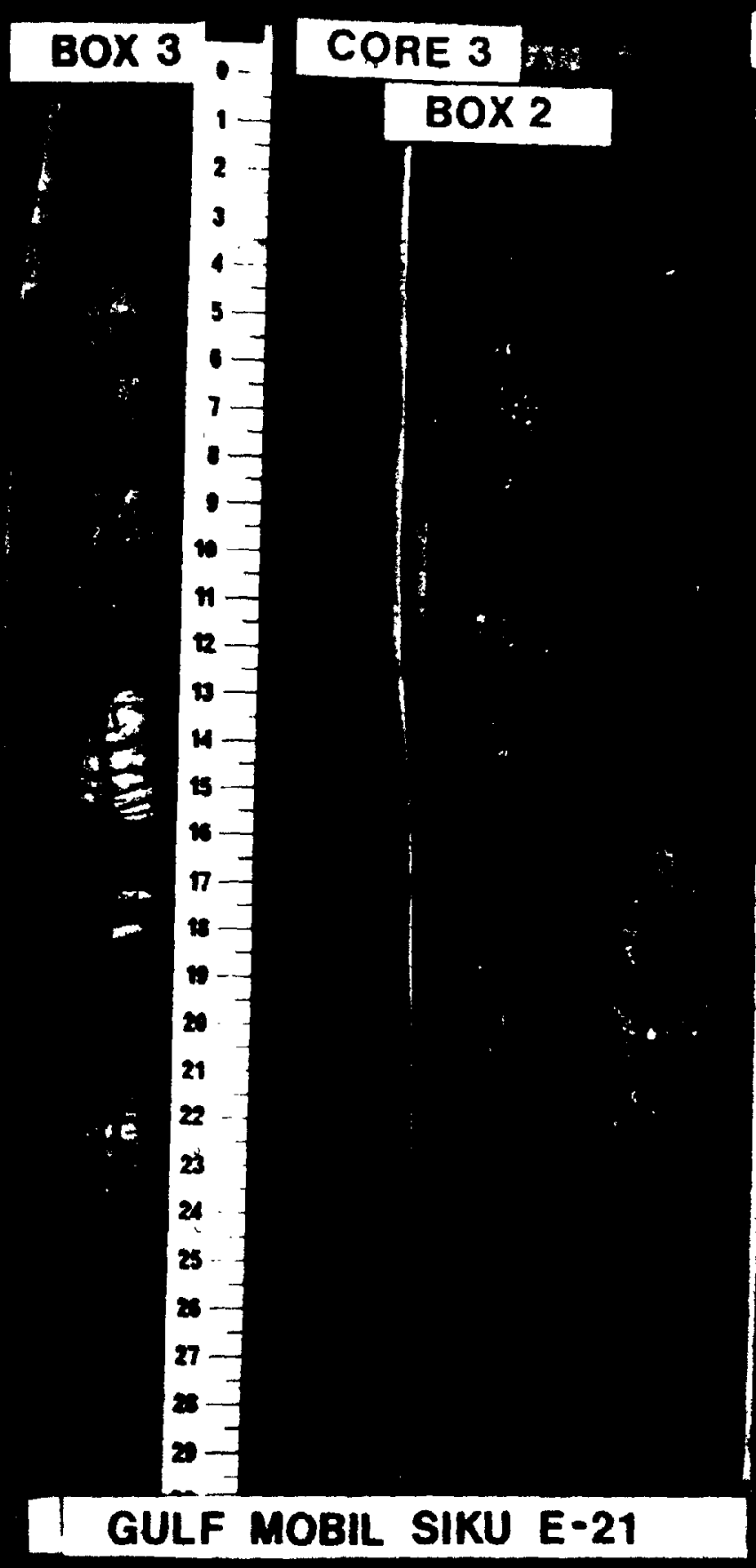

BOX 1

1 
Plate 3

Core, 2806-2810.4 metre interval, Siku A-12 well. Fine to coarse-grained cross-bedded quartzose sandstone, transitional member. Arenites from the top of the core are interpreted as intertidal sands and are underlain by an erosive, pebbly, carbonaceous channel sand. Note that lower core box is upside-down. Scale in inches. 


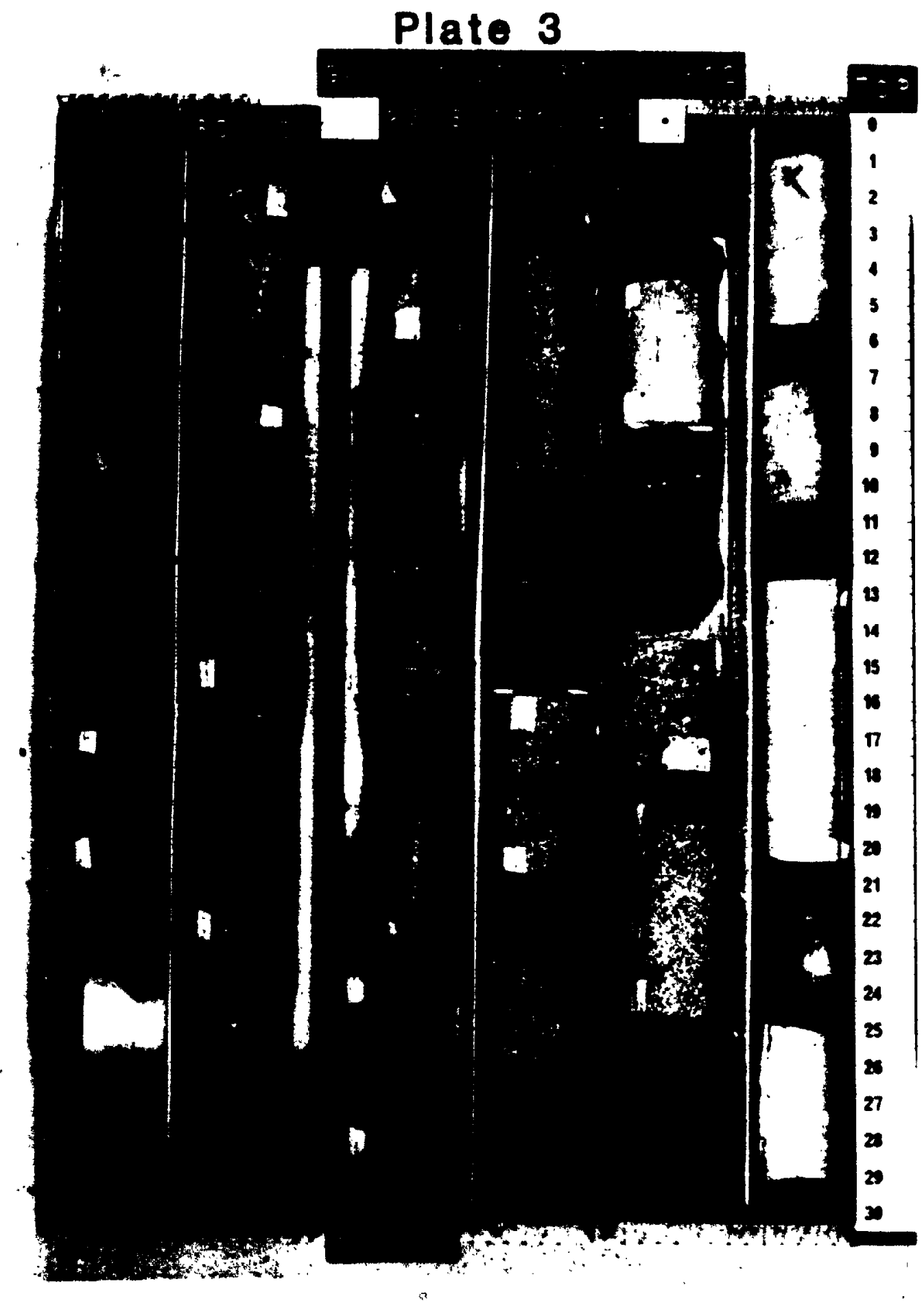


Plate 4

A. Coarse-grained quartzose sandstone, 2808.5 metre level, Siku A-12 well. Note the high porosity of which some is apparently moldic. Transitional member.

B. Erosional contact between the fine-grained sand flat and congloweratic facies of the underlying channel sand, 2808 metres, Siku A-12 well. Transitional member.

C. High-angle bedding dip in the fine-grained quartzose sandstones, 2805.5 metres, Siku A-12 well. Transitional member.

D. Low-angle cross-bedding in the quartzose sandstones, 2954.5 metre level, Siku E-21 well. Transitional member.

E. Wavy bedding in nearshore sandstones, 2862 metre level, Siku A-12 well. Marine member.

F. A conglomeratic channel-base, 2967 metre level, Parsons P-41 well. Note the high porosities associated with the sandstone matrix. Marine member. 
Plate 4

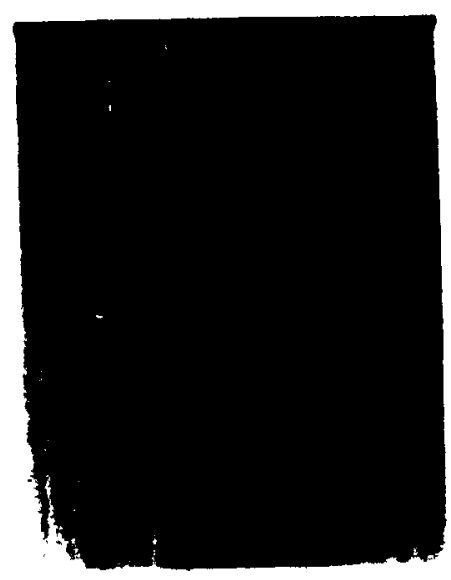

A
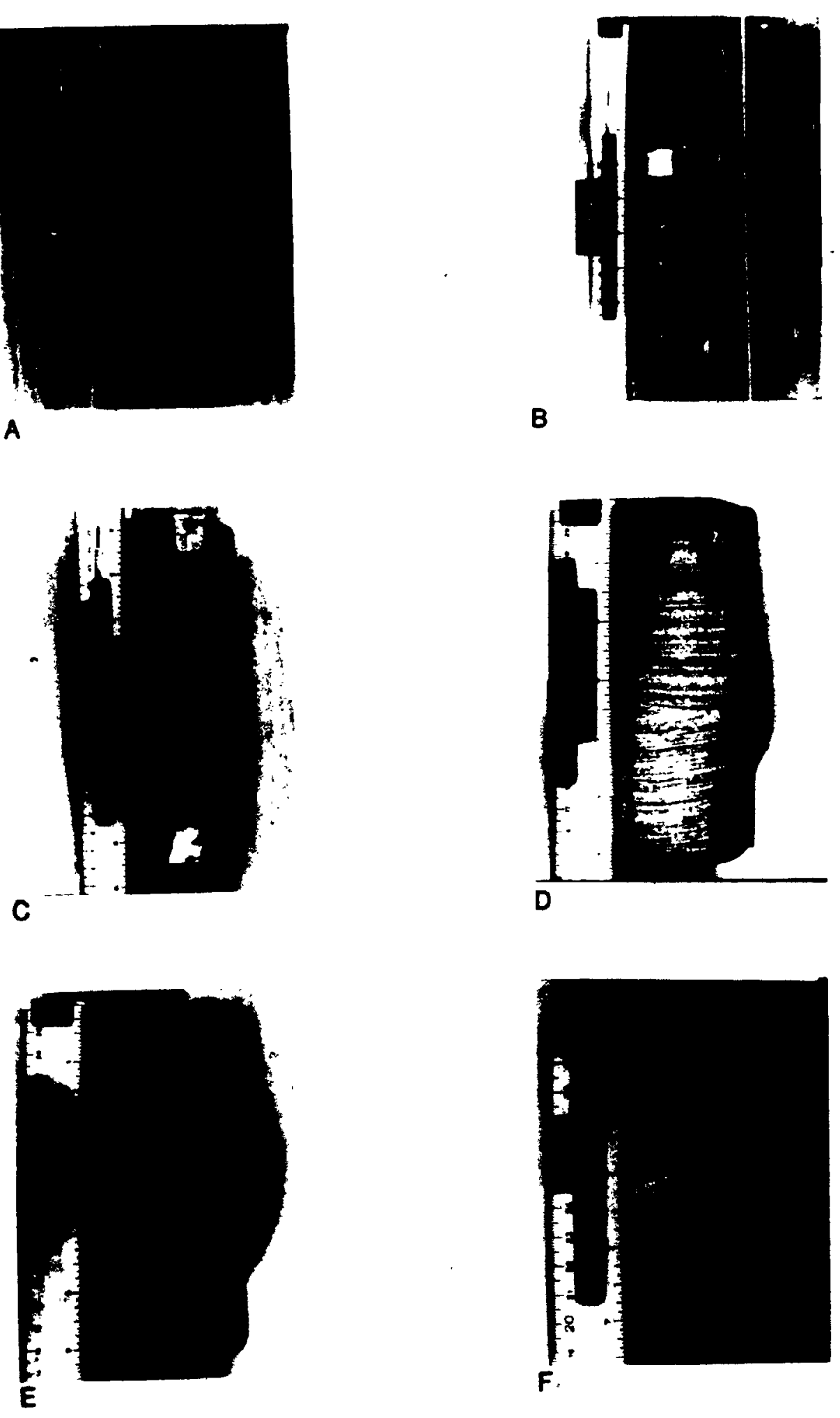
Plate 5

A. Sub-horizontal thinly bedded quartzose lower offshore sandstone, the upper part of which is thoroughly bloturbated ; Chondrites cf. and unidentifiable fauna. From 2949 metres, Siku E-21. Transitional member.

B. Thoroughly bioturbated fine-grained upper offshore rock showing both Helminthoida (h) and Chondrites (c) of burrows. From 2955 metres, SikuE-21. Transitional member.

C. Teichichnus cf. burrows (arrows) in a silty to very fine-grained lagoonal rock. From 2713.5 wetres, Siku A-12. Marine member.

D. Probable Chondrites cf. burrows in the lagoonal rocks, 2974 metres, Parsons P-41. Marine member.

E. Possible Chondrites cf. burrows in the crossbedded fine-grained quartzose beach sandstones, 2973 metres, Parsons P-41. Marine member.

F. Probable Teichichnus cf. burrows in thin horizontally-bedded lagoonal sandstones;, 2975.5 metres, Parsons P-41. Marine member. 
Plate 5
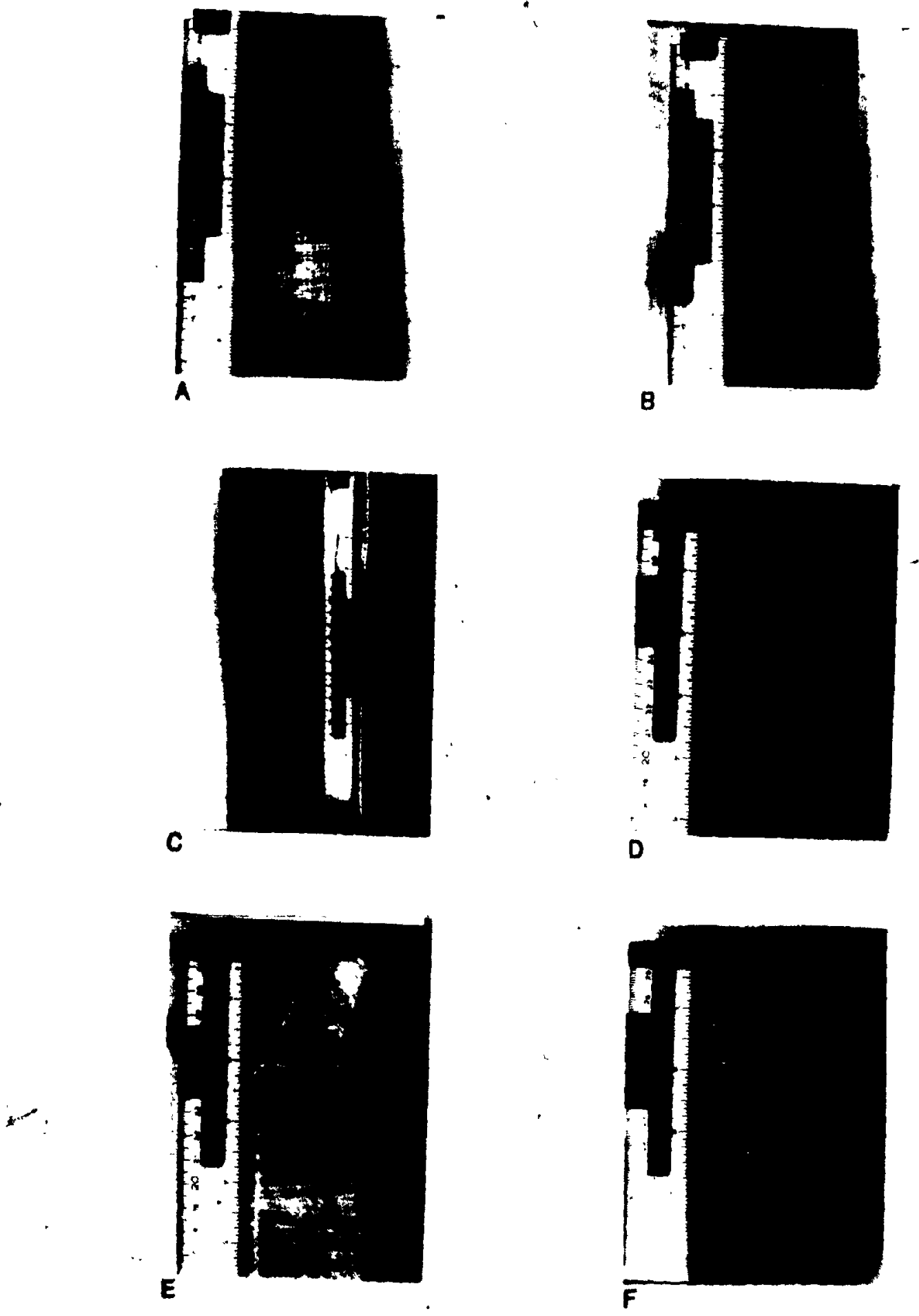
Plate 6

A. Rounded quartz overgrowth (defined by dust-linearrow) around a broken rounded quartz grain implying a multi-cycle origin. Parsons F-09 well at 2997.4 metres, McGulre Formation. Thin section photomicrograph, XP light.

B. Intraparticle porosity (a) in a detrital chert grain, after the dissolution of a dolomite rhomb. Parsons P-41, 2974.4 m, marine member. Thin section photomicrograph, PP light.

C. Detrital chert (a) showing pellet ghosts and intraparticle porosity after dissolution of some pellets. Siku E-21, $3053.8 \mathrm{~m}$, non-marine member. Thin section photomicrograph, PP light.

D. Significant intraparticle porosity (a) in a large polycrystalline quartz grain (b). Siku E-21, $3053.8 \mathrm{~m}$, non-marine member. Thin section photomicrograph, PP light.

E. Excellent example of partially dissolved feldspar (a). Parsons $\mathrm{N}-10,2760.5 \mathrm{~m}$, non-marine member. Thin section photomicrograph, PP light.

F. An example of silica overgrowth on a nearperfectly round quartz grain. The "dust line" coating the original detrital grain is unusually well-d fined in this specimen. Parsons $\mathrm{N}-10,2753.2 \mathrm{~m}$, non-marine member. Thin section photomicrograph, XP light.

G. Loosely-packed quartz grains showing silicaovergrowths coalescing. Porosity is dark grey. Parsons L-43, 2942.8m, non-marine member. Thin section photonicrograph, PP light.

H. Exceptionally well-developed crystalline quartzovergrowths (a). Typically the detrital core is not recognizable. Parsons L-43, 2943.5m, non-marine member. Thin section photomicrograph, PP 1 ight. 
Plate 6
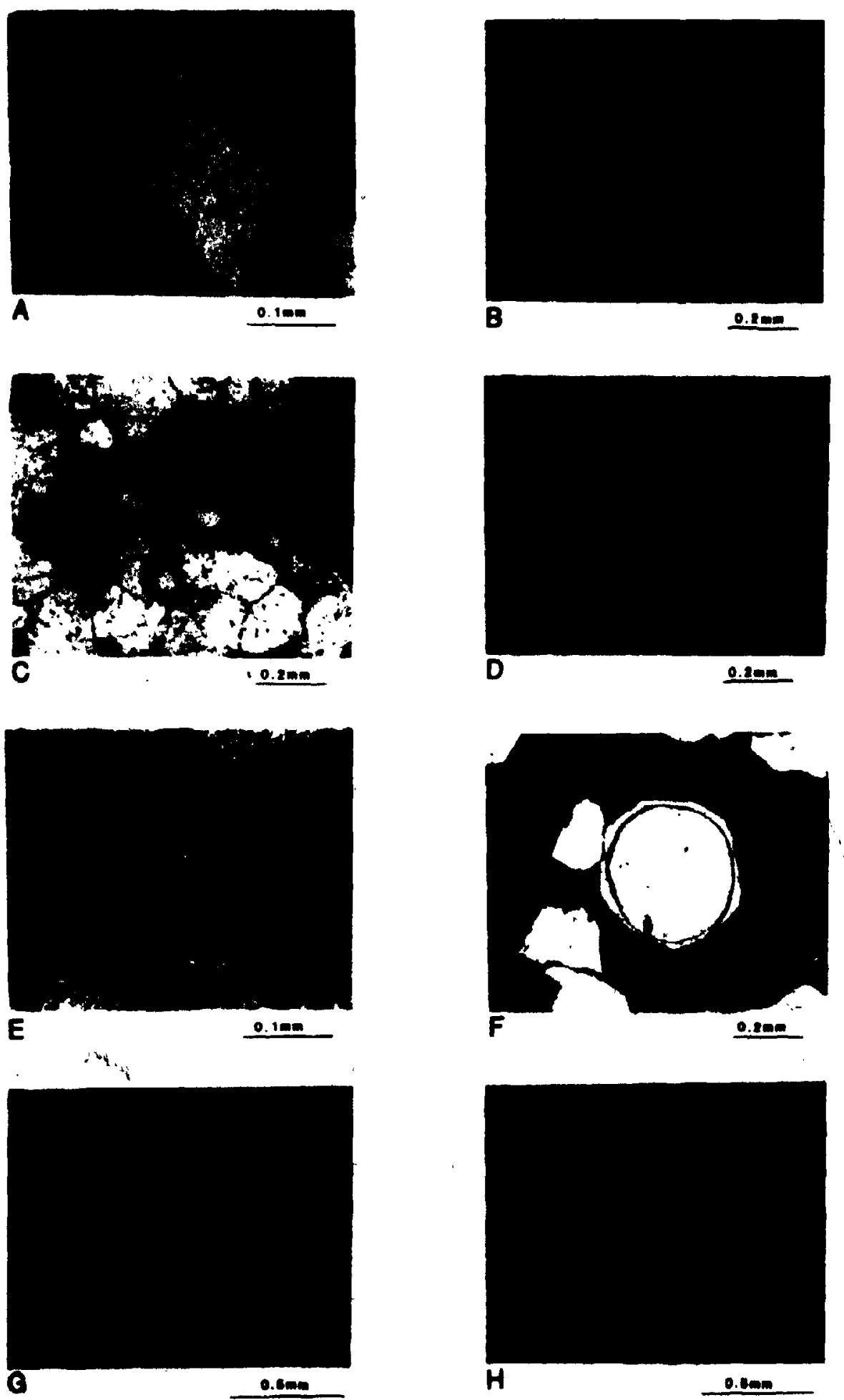
Plate 7

A. Scanning electron photomicrograph of welldeveloped quartz overgrowths (a) partially filling pore space. The grains are incompletely coated with authigenic 1111 te-dominated clag. Parsons $\mathrm{N}-10$, 2760.6m, non-marine member.

B. Scañing electron photomicrograph of advanced quartz overgrowths. Porosity loss 18 more advanced than in Plate 7a. Later 111 ite-dominated clay (a) is present. Parsohs N-10, 2858.7m, Martin Creek Formation.

C. Extreme porosity 1088 due to quartz overgrowths nearly eliminating porosity. Late illite coats some of the grains. Parsons $\mathrm{N}-10,2803.9 \mathrm{~m}$, non-marine member. Scanning electron photomicrograph

D. Scattered clear calcite cement (a) in a quartz arenite. Parsons F-09, 2850.3m, transitional member. Thin section photonicrograph, PP light.

E. Carbonate cement (a), probably calcite, in a quartz arenite. The slightly-dark shade of the carbonate is likely due to the presence of illitedoninated clays as tmpurities. Some quartz grains (b) show significant corrosion along their edges suggesting previous attack by now dissolved carbonate cement. A thin layer of dark illite now coats most grains. Siku E-21, 3052.6m, transitional member. Thin section photonicrograph, PP light.

F. Late pore-filling calcite cement (a) partially replacing a quartz grain (b). Parsons $P-41,2973.2 m$, marine member. Thin section photowicrograph, XP light.

G. Scattered calcite cement (a) within a looselypacked quartz arenite. The calcite present is remant after the dissolution event that removed the majority of the pore-filling calcite. Siku E-21 3047.4m, transitional member. Thin section photomicrograph, PP light.

H. Pore-filling illite (a) both totally and partially filling the pore spaces present (b). Siku A-12, i2720m, marine wember. Thin section photonicrograph, PP light. 


\section{Plate 7}

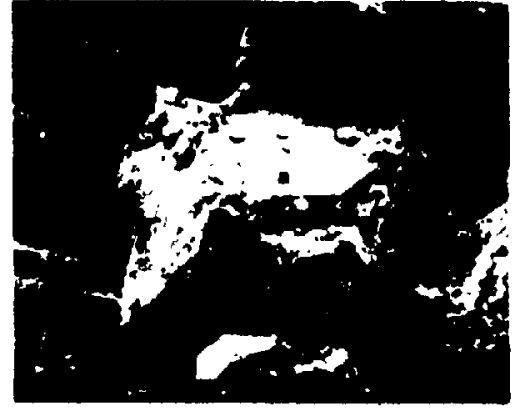

A

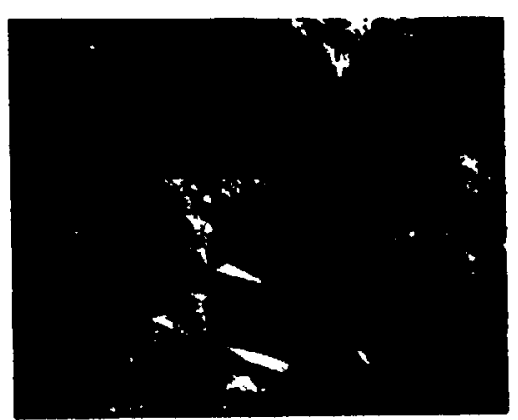

C.
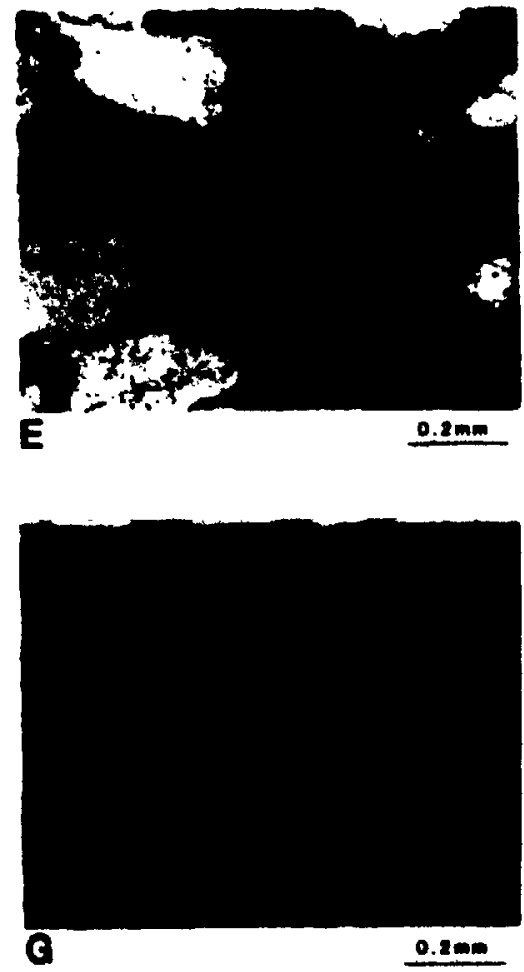
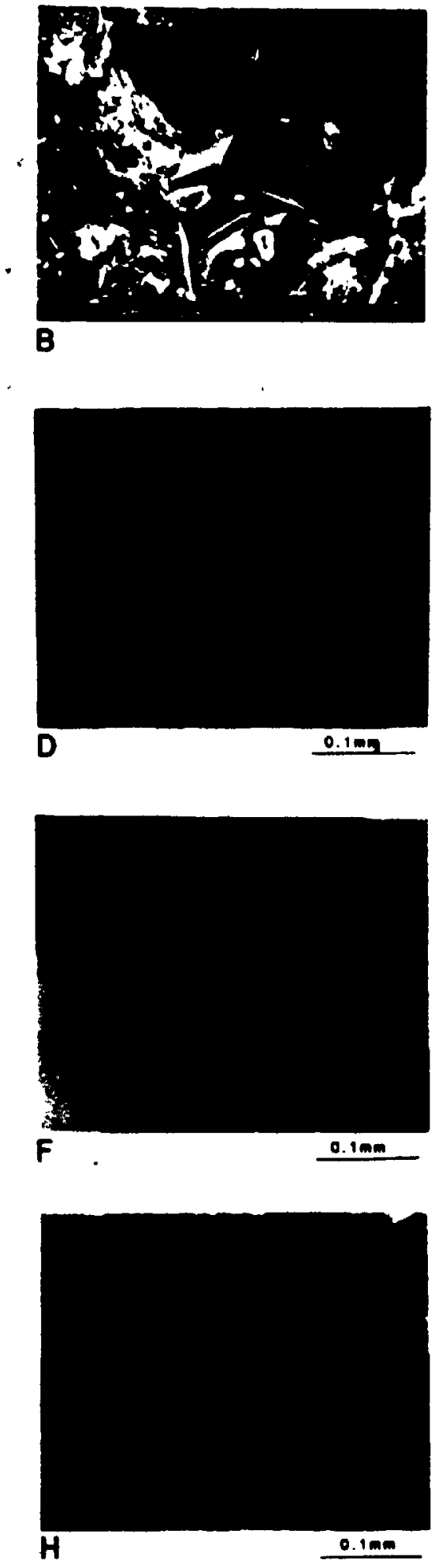
Plate 8

A. Authigenic illite-montmorillonite clay (a) partially infilling pore space (b). Note the lath-like projections of the illite-dominated clay. Parsons N10, 2803.9m, non-marine member. Scanning electron photomicrograph.

B. Abundant pore-filling authigenic illite-dominated clay (a) eliminating interparticle porosity. Note that the clay is a post-silica-overgrowth (b) feature. Parsons $\mathrm{N}-10,2752.0 \mathrm{~m}$, non-marine member. Scanning electron photomicrograph.

C. Pore space between quartz grains (a) totally filled with a tightly arranged, laminated, authigenic illite-dominated clay. Although the clay morphology resembles detrital chlorite, X-ray examination indicatesotherwise. Reindeer G-04, 2937.1 m, marine member. Scanning electron photomicrograph.

D. Pore space between quartz overgrowths(a) filled with morphologically indeterminable clay (b). X-ray analyses suggest this clay is illite-dominated. Parsons $N-10,2765.1 \mathrm{~m}$, non-marine member. Scanning electron photomicrograph.

E. Interparticle porosity between loosely-packed quartz grains (a) reduced to near-zero by the presence of abundant authigenic, illite-dominated clay (b). Reindeer G-04, 2921.5m, warine member. Scanning electron photomicrograph.

F. A thin layer of illite clay (a-very dark) coating most quartz grains. Note the loosely-packed and corroded nature of the quartz grains attesting to dissolution of previously existing carbonate cement. Parsons $\mathrm{N}-10,2758.1 \mathrm{~m}$, non-marine member. Thin section photomicrograph, PP light.

G. Heavily overgrown quartz (a) covered by a thin layer of locally pore-bridging illite (b). Parsons N10. 2765.2m, non-marine member. Scanning electron phoconicrograph.

H. Close-up of a thin layer of illite (a) coating a quartr grain. Note the presence of abundant residual secondary pore space (b). Reindeer A-01, 2308.9m, transitional aber. Scanning electron photonicrograph. 
Plate 8
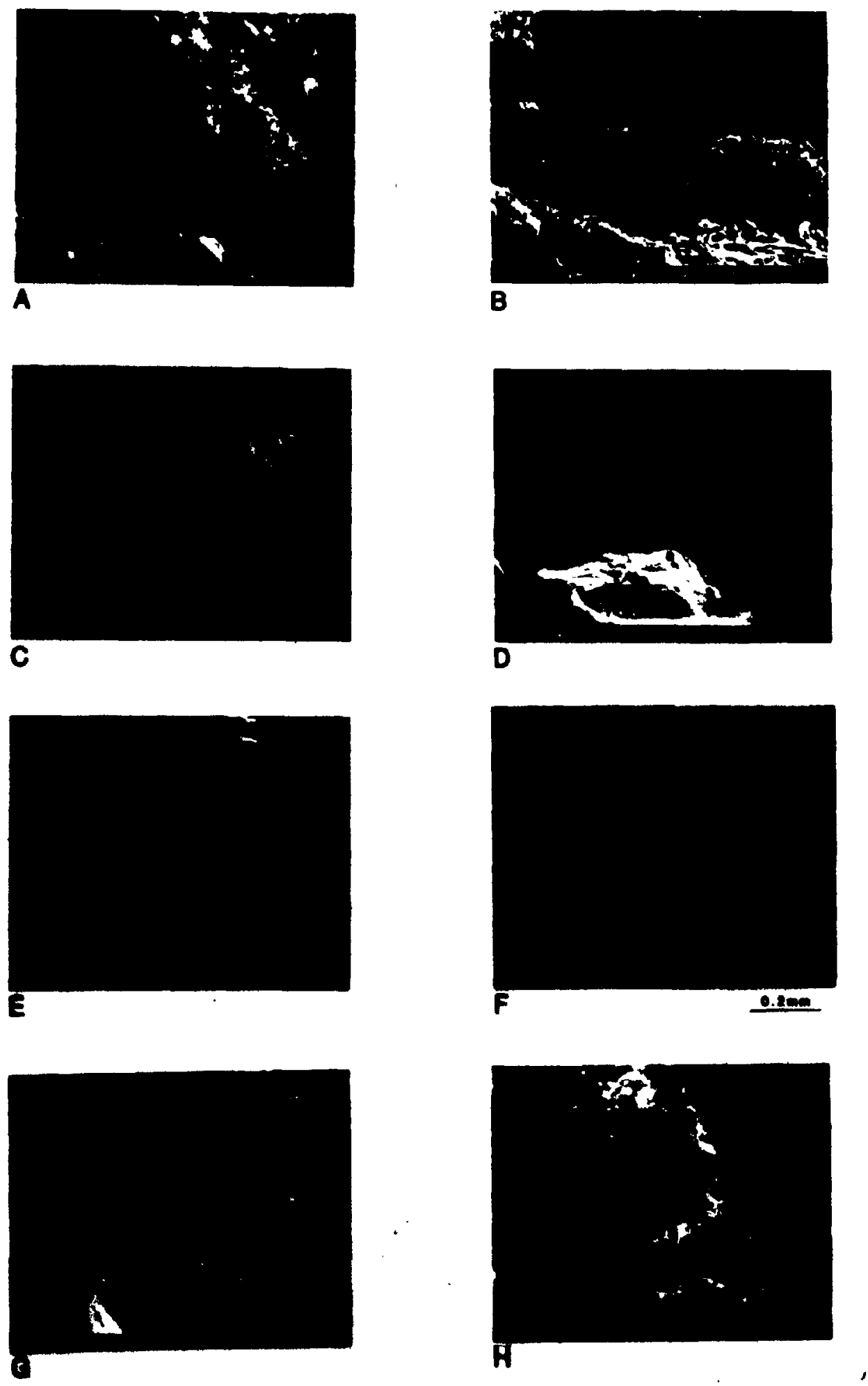


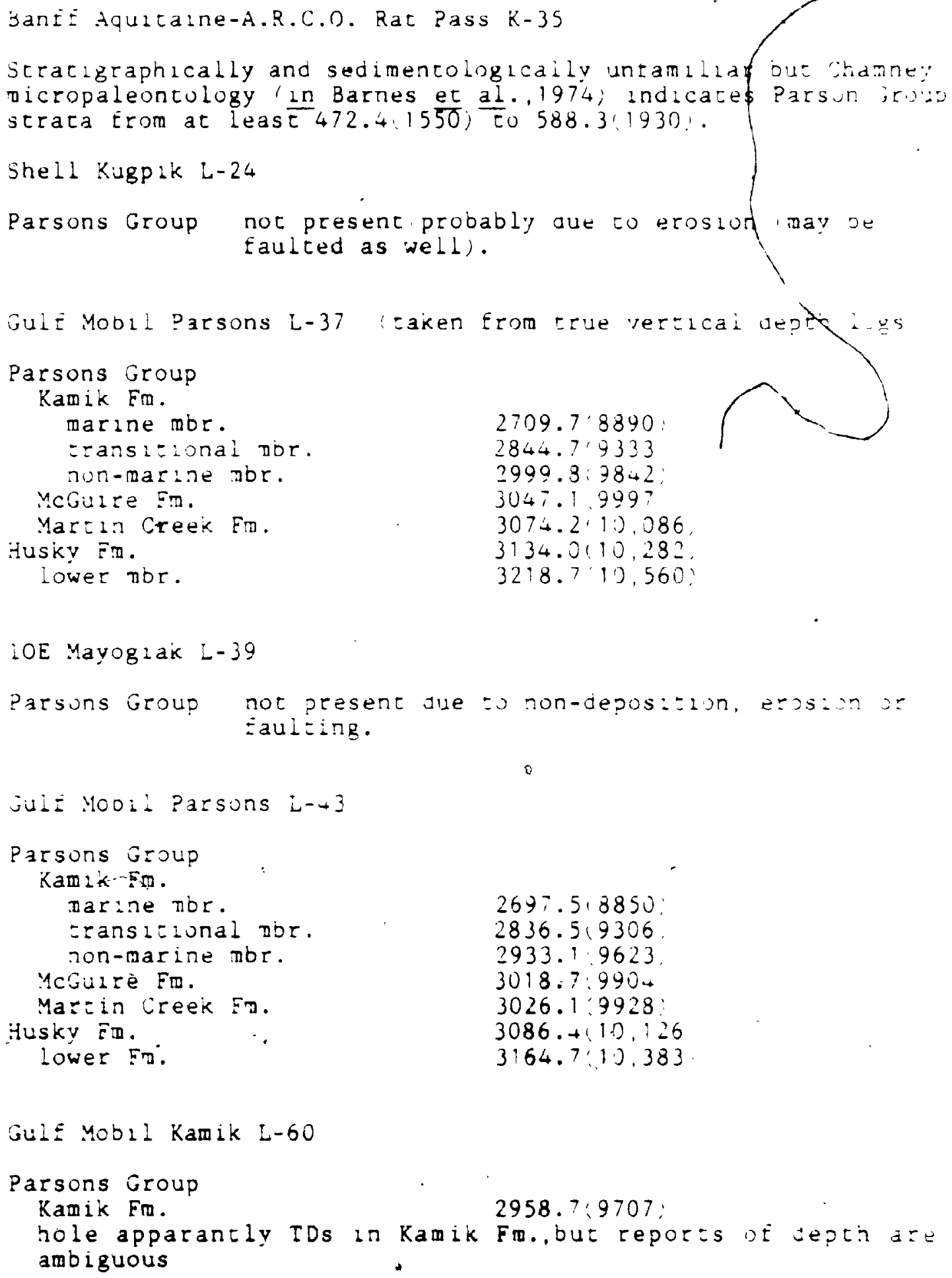


Plate 8
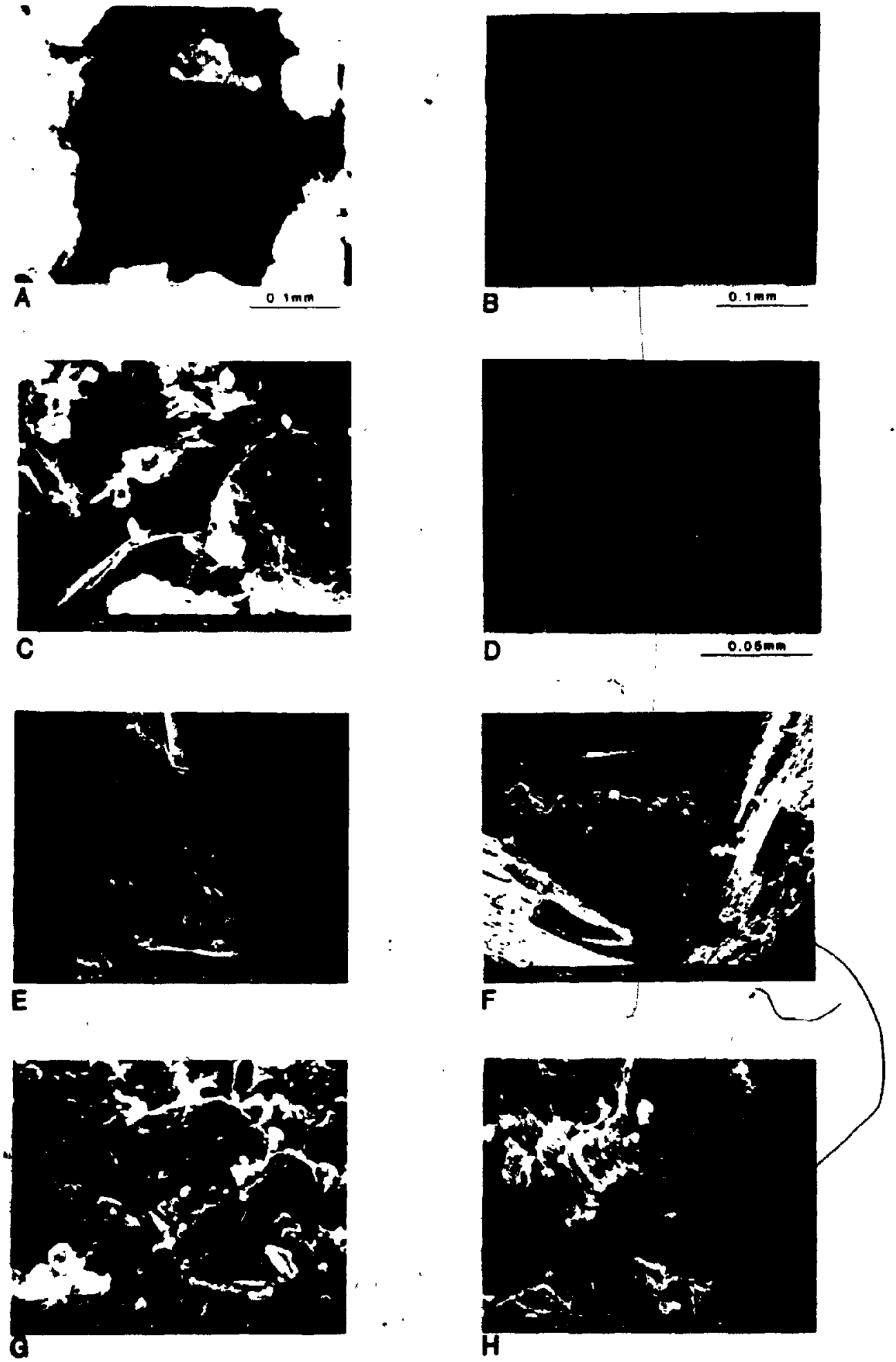
Plate 10

A. Opaque disseminated lath-like pore-filling pyrite patches (a). Note that the quartz grains are usually in corrosive contact with the pyrite. Pore-filling authigenic illite (b) is present also. Siku A-12, $2723.4 \mathrm{~m}$, marine member. Thin section photomicrograph, PP light.

B. A patch of pyrite cement (black) containing loosely-packed corroded quartz grains. Intact packing in the sandstone is observed in the right part of the photograph. Parsons N-10, 2850.2ه, Martin Creek Formation. Thin section photomlcrograph, PP light.

C. Finely crystaline, disseminated, pore-filling pyrite (a). Note that the pyrite has crystallized upon a well-developed quartz overgrowth (b), attesting to its later origin. Reindeer A-01, 2305.2m, transitional member. Scanning electron photomicrograph.

D. Moldic porosity created from the dissolution of feldspar (note the abundant feldspar remnants (a) in the pore space). A relatively higher authigenic illite content (b) is present in the pore as a dissolution product of the feldspar. Siku A-12, $2722.8 \mathrm{~m}$, marine member. Thin section photomicrograph, PP light.

E. Partially dissolved feldspar (a). Dissolution has proceeded along the near-orthogonal crystallographic axes. Reindeer A-01, 2308.9m, transitional member. Scanning electron photomicrograph.

F. Well-cleaved carbonate (calcite?) cement (a) showing partial dissolution (b). Parsons N-10, $2798.1 \mathrm{~m}$, non-marine member. Scanning electron photomicrograph.

G. Kaolinite booklets (a) filling interparticle pore space between silica cemented quartz grains. Crystal

* faces of overgrowths are on numerous grains and grain b shows the detrital quartz core. Parsons N-10, 2797,5m, non-marine member. Thin section photomicrograph, PP light.

H. Interparticle pore space between overgrown quartz (a) filled with calcite cement (b) and some indeterminable authigenic clays (c). Parsons $\mathrm{N}-10$, 2803.9m, non-marine member. Scanning electron photomicrograph. 
Plate 10
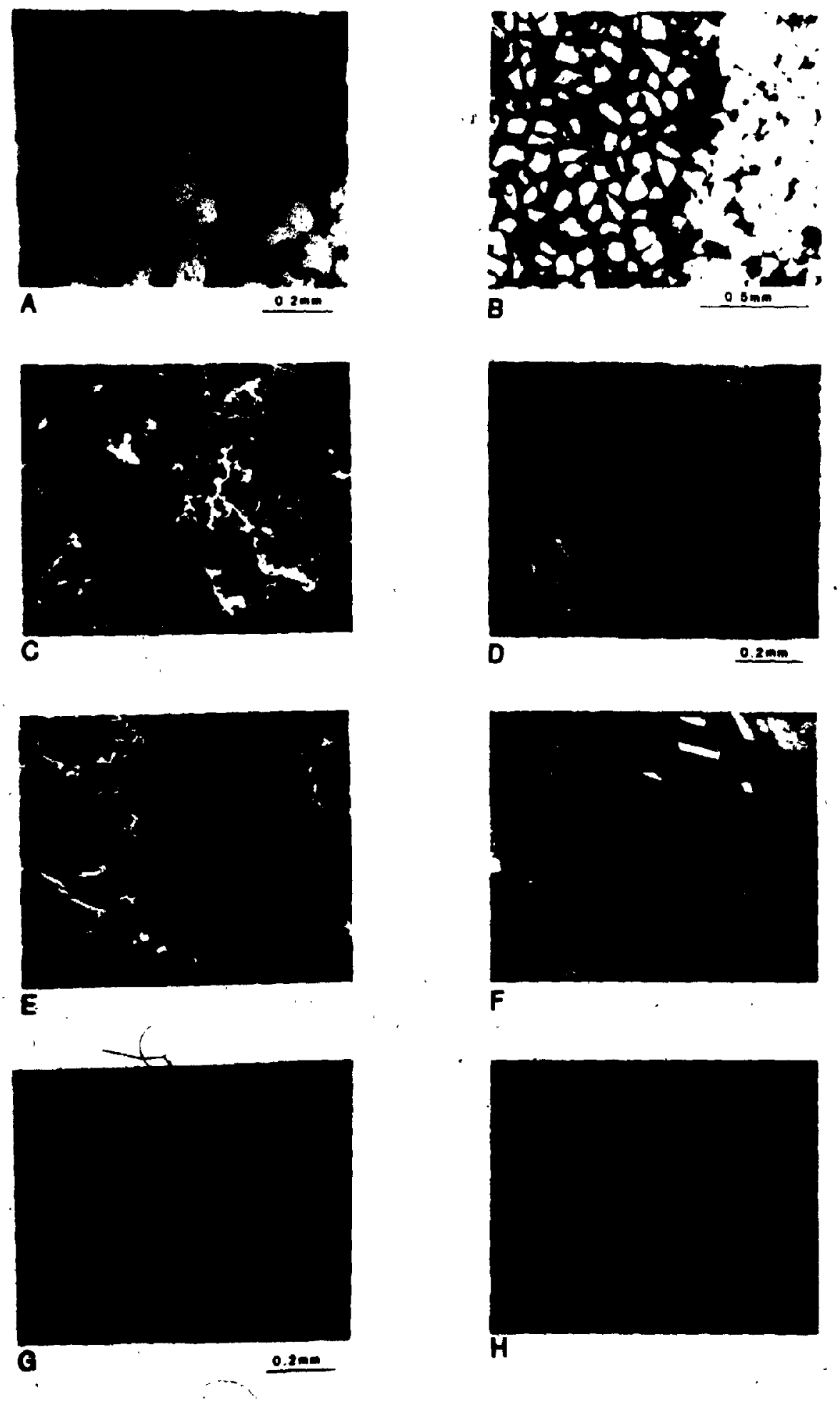
Plate 11

A. Authigenic kaolinite booklets (a) and illitedominated clays (b), precipitated on an overgrown silica grain (c). The co-existence of kaolinite and illite attests to overlapping chemical conditions of stability and possibly formation. Parsons $N-10$, $2798.1 \mathrm{~m}$, non-marine wember. Scanning electron photomicrograph.

B. Thin section photomicrograph showing interparticle porosity (dark) in a quartz arenite where abundant crystalline overgrowths are recognizable (a). The porosity is probably a result of mesogenetic carbonate dissolution. Parsons L-43, 2942.8m, non-marine member. PP light.

C. Preudohexagonal kaolinite plates and deep impressions of kaolinite booklets (a) on a crystalline quartz. overgrowth face (b). It is likely that the overgrowths grew around an already nucleated kaolinite crystal. Parsons N-10, 2799.0m, non-marine member. Scanning electron photomicrograph.

D. Large oversized moldic porosity (a). The occurrence of a relatively large quantity of illite clay (b) suggests dissolution of feldspar. Siku A-12, $2725.5 \mathrm{~m}$, marine member. Thin section photomicrograph, PP light.

E. Authigenic illite-dominated clay (a) and silica overgrowths causing an advanced loss of general pore space (c). Parsons N-10, 2798.1m, non-marine member. Scanning electron photomicrograph.

F. Close-up of plate $9 e$ showing interbooklet wicroporosity in kaolinite. Parsons N-10, 2798.1m, non-marine member. Scanning electron photomicrograph. 
Plate 11
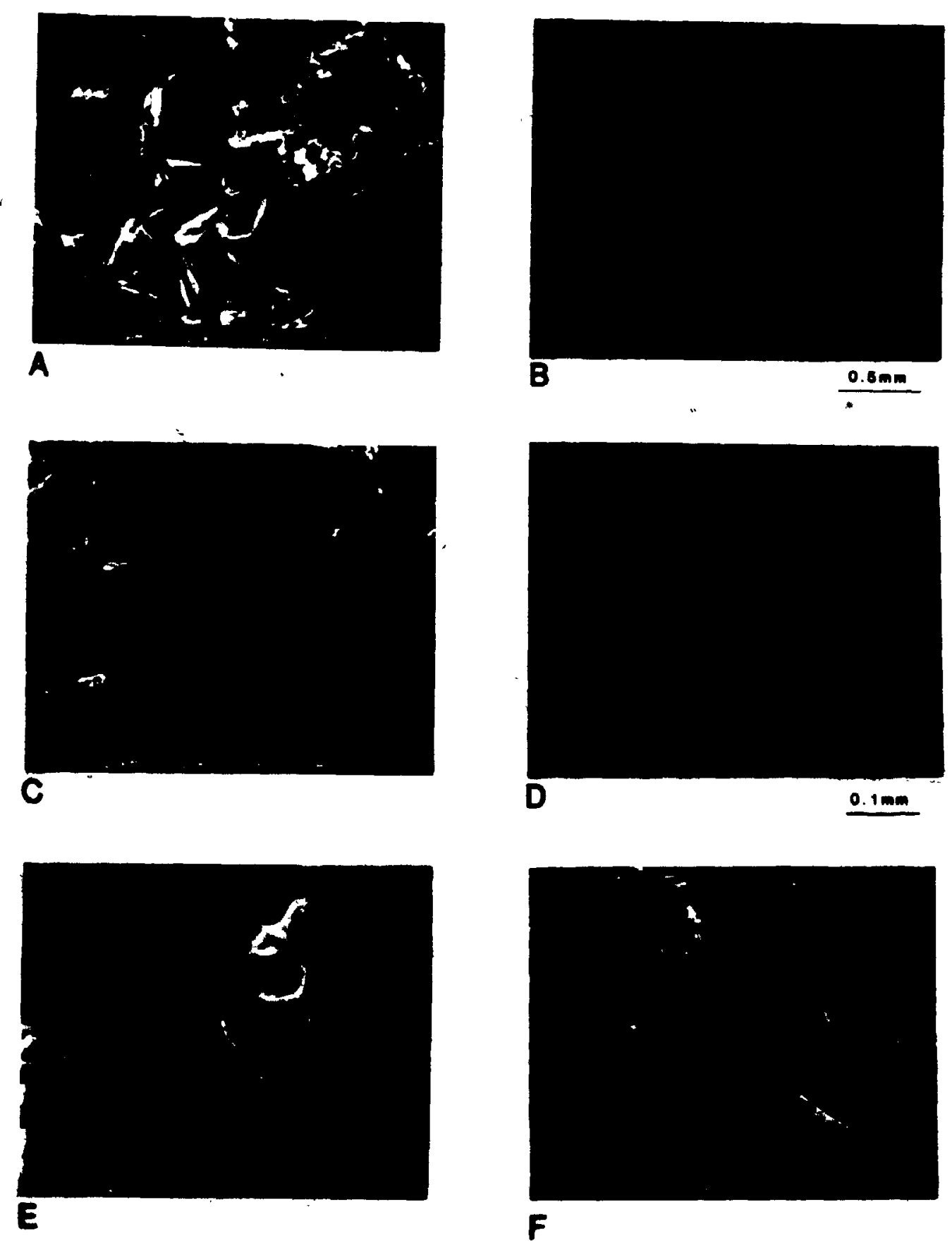


\section{REFEREACES}

Almon,W.R., 1981. Depositional environment and diagenes is of Permian Rotliegendes sandstones in the Dutch sector of the Southern North Sea : in Clays and the Resource Geologist, F.J.Longstaffe (ed.); Mineralogical Association of Canada, Shortcourse Handbook 7,Calgary, p. 119-147.

Barnes, C.R., Brideaux,W.W. ,Chamney, T.P. ,Clowser, D.R., Dunay, R.E., Flsher,M.J.,Fritz,W.H., Hopkins, W.S.Jr.,Jeletzky,J.A., McGregor, D.C. , Norford, B.S., Norris, A.W. , Pedder.A.E.H. , Rauwerda, P.J . , Sherrington, P.F., Sliter,W.V., Tozer, E.T. Uyeno,T.T., and Waterhouse,J.B., 1974. Biostratigraphic determinations of fossils from the subsurface of the Northwest and Yukon Territories;Geological Survey of Canada,Paper 74-11.

Berner,R.A.,1980. Early diagenesis:A theoretical approach. Princeton Press, 250 pp..

Brideaux, W.W. , Chamney, T.P. ,Dunay, R.E., Fritz,W.H. ,Hopkins, W.S.Jr. , Jeletzky, J.A. , McGregor, D.C. , Norford, B.S., Norris, A.W. , Pedder, A.E.H., Sherrington.P.F., Sliter,W.V., Sweet, A.R., Uyeno, T.T., and Waterhouse,J.B.,1975. Biostratigraphic determinations for fossils from the subsurface of the Districts of Franklin and Mackenzie;Geological Survey of Canada,Paper 74-39.

Brideaux, W.W. ,Clowser, D.R., Copeland, M.J., Jeletzky, J.A., Norford, B.S. ,Norris, A.W. ,Pedder,A.E.H., Sweet, A.R., Thorsteinsson, R., Uyeno, T.T., and Wall, J.,1976. Biostratigraphic determinations from the subsurface of the Districts of Franklin and Mackenzie and the Yukon Territory;Geological Survey of Capada, Paper 75-10.

Brideaux,W.W., and Myhr,D.W.,1976. Lithostratigraphy and dinoflagellate cyst succession in the Gulf Mobil Parsons N-10 well. District of Mackenzie;Geological Survey of Canada, Paper 76-1.B, P.235-249.

Cant,D.J., 1978. Development of a Eacles model for sandy braided river sedimentation: Comparison of the South Saskatchewan River and the Battery Point Formation: in Fluvial Sedimentology, A.D. Miall (ed.); Canadian Socíety of Petroleum Geologists, Memoir 5, p.627-640.

Chamberlain,C.K.,1978. Recognition of trace fossils in cores: in Trace Fossil Concepts; Society of Economic Paleontologists and Mineralogists, Short Course No. 5, p.119-166.

Chayes,F.,1956. Petrographic Modal Analysis: An elementary statistical appraisal. John Wiley and Sons, Inc., New York, $113 \mathrm{pp}$.. 
Cóte,R.P.,Lerand,M.M., and Rector, R.J.,1975. Geology of the Lower Cretaceous Parsons Lake gas field, Mackenzie Delta, Horthwest Terricories: in Canada's Continental Margins, C.J. Yorath, E.R. Parker, andD.J. Glass. (eds.); Canadian Society of Petroleum Geologists, Memoir 4, p:613-632.

Dapples,E.C.,1967. Diagenes is of Sandstones; in Diagenes is in Sediments. Developments in Sedimentology 8 , Chapter 3. G. Larsons and G.V. Chilingar (eds.), Elsevier, p. 91-126.

Deer,W.A., Howie, R.A.,Zussman,J.,1966. An Introduction to the Rock-forming Minerals. John Wiley and Sons, New York. 207 pp..

Dickinson, K.A., Berryhill,H.L.Jr, and Holmes, C.W.,1972. Criteria for recognizing ancient barrier coastlines; in Recognition of Ancient Sedimentary Enviconments, J.K. Righy and Wm. K. Hamblin (eds.); Society of Economic Paleontologists and Mineralogists, Special Publication 16, p.192-21中.

Dixon J.,1982a. Sedimentology of the Neocomian Plesons Group in the subsurface of the Mackenzie Delta area, Arctic Canada; Bulletin of Canadian Petroleum Geology, Vol. 30, No. 1. p. $9-28$.

-......,1982b. Jurassic and Lower Cretaceous subsurface stratigrapiy of the Mackenzie Delta-Tuktoyaktuk Peninsula, N.W.T.; Geological" Survey of Canada, Bulletin 359.

Elliot, T.,1983. Clastic shorelines: in Sedimentary Environments and Facies,H.G.Reading(ed.); Elseviler, New York, p.143-177.

Folk,R.L.,1959. Petrology of Sedimentary Rocks. Hemphill. Publishing Co., 154 pp..

-.......1968. Petrology of Sedimentary Rocks. Hemphill Publishing Co., 170 pp..

-...- 1975. Petrology of Sedimentary Rocks. Hemphill Publishing Co., 170 pp..

Gulf Canada Resources Inc. Calgary. Unpublished data.

Hayes,J.B.,1979. Sandstone diagenesis-the hole cruth: in Aspects of Diagenesis; Society of Economic Paleontologists and Mineralogists, Special Publication No. 26, p.127-139."

Hea, J.P. , Arcuri, J. ,Campbell, G.R., Fraser, I., Fuglem, M.0. ,0'Bertos, J.J,Smith,D.R., and Zayat,M.,1980. Post-Ellesmerian basins of Arctic Canada: Their depocentres, rates of sedimentation and petroleum potential, in A.D.Miall, (ed.), Facts and Principles of World Petroleum Occurrences: Canadian Society of Petroleum Geologists, Memoir 6, p.447-488. 
Heward,A.P., 1981. A review of wave-dominated clastic shoreline deposits; Earth Science Reviews,17,p.223-276.

Hilliard,J.E. and Cahn,J.W.,1961. An evaluation of procedures in quantitative metallography for volume-fraction analysis. Transactions of the Metallurgical Society of AIME, p.344-352.

Hof fman, J. and Hower,J.,1979. Clay mineral assemblages as low grade metamorphic geothermoneters: Application to the thrust faulted disturbed belt of Montana,U.S.A.: in Aspects of Diagenesis; Soclety of Economic Paleontologists and Mineralogists, Special, Publication No. 26, p.55-79.

Hunter,R.E.,Clifton,H.E., and Phillips,R.L., 1979. Depositional processes, sedimentary structures, and predicted vertical sequences in barred nearshore systems, Southern Oregon coast; Journal of Sedimentary Petrology, Vol.49, No.3, p.711-726.

Hutcheon, I.,1981. Applications of thermodynamics to clay minerals and authigenic mineral equilibria: in Clays and the Resource Geologist, F.J.Longstaffe (ed.); Mineralogical Asssociation of Canada, Short Course Handbook 7. Calgary. p. 169-191.

Jeletzky,J.A.,1958. Uppermost Jurassic and Cretaceous rocks of Aklavik Range, northeastern Richardson Mountains, Northwest Terricories; Geological Survey of Canada, Paper 58-2.

..... 1960. Uppermost Jurassic and Cretaceous rocks, east Elank of Richardson Mountains between Stoney Creek and lower Donna River, Northwest Territories; Geological Survey of Canada, Paper 59-14.

-...-2.-. 1961. Eastern slope, Richardson Mountains; Cretaceous and Tertiary structural and regional significance: in Geology of the Arctic, G.0.Raasch (ed.); Proceedings lrst International Symposium on Arctic Geology, University of Toronto Press, Vol.1, p.532-583.

1967. Jurassic and (?) Triassic rocks of the eastern slope of Richardson Mountains, northwestern District of Mackenzie; Geological Survey of Canada, Paper 66-50.

........ 1974. Contribution to the Jurassic and Cretaceous geology of northern Yukon and District of Mackenzie, Northwest Territories; Geological Survey of Canada, Paper 74-10.

........... 1975. Jurassic and Lower Cretaceous paleogeography and depositional tectonics of Porcupine Plateau, adjacent areas of north Yukon and those of Mackenzie District; Geological Survey of Canada, Paper 74-16. 
1980. Lower Cretaceous and Jurassic rocks of McDougall Pass area and some adjacent areas of north-central Richardson Mountains, northern Yukon Territory and northwestern District of Mackenzie, N.W.T. (NTS $116 \mathrm{P} / 9$ and 116P/10):A reappraisal; Geological Survey of Canada, Paper $78-22$.

.......... in prep. Six new Lower Cretaceous Formations in Richardson Mountains, northern Yukon and District of Mackenzie, Northwest Territories (NTS 106,107,116,117). Geological Survey of Canada.

Langhus,B.G., 1980. Generation and migration of hydrocarbons in the Parsons Lake area, N.W.T., Canada: in Facts and Principles of World Petroleum Occurrence, A.D.Miall (ed.); Canadian Society of Petroleum Geologists, Memoir 6, p.523-534.

Lerand,M.M.,1973. Beaufort Sea: in The Future Petroleum Provinces of Canada, R.G.M. McGrossman (ed.); Canadian Society of Petroleum Geologists, Memoir 1, p.315-386.

Mellon,G.B.,1964. Discrimatory analysis of calcite and silicate cemented phases of the Mountain Park sandstone: Journal of Geology, Vol.72, No.6, p.786-809.

Miall,A.D.,1978. Lithotacies types and vertical profile models in braided river deposits: a summary:in Fluvial Sedimentology, A.D.Miall (ed.); Canadian Society of Petroleum Geologists, Memoir 5, p.597-604.

Myhr,D.W., and Gunther P.R.,1974. Lithostratigraphy and coal reflectance of a Lower Cretaceous deltaic succession in the Gulf Mobil Parsons F-09 borehole, N.W.T.; Geological Survey of Canada, Paper 74-1B, p.24-28.

Myhr,D.W., and Young F.G.,1975. Lower Cretaceous (Neocomian) sandstone sequence of Mackenzie Delta and Richardson Mountains area; Geological Survey of Canada, Paper 75-1C, p. 247-266.

Pettijohn,F.J.,Potcer,P.E., and Siever,R.,1972. Sand and Sandstone. Berlin-Heidelberg, New York: Springer, 618 pp..

Powers,M.C.,1953. A new roundness scale for sedimentary particles: Journal of Sedimentary Petrology, Vol.23, p.117119.

Pryor,W.A.,1968. Reservoir inhomogeneities of Recent sandbodies. Final Report, American Petroleum: Institute Research Project

91-B. American Petroleum Institute. 
Reineck,H.E., and Singh, I.B.,1973. Depositional Sedimentary Environments-With Reference to Terrigenous Clastics; SpringerVerlag. Berlin, 439 pp..

Rust,B.R.,1978. Depositlonal models for braided alluvium: in Fluvial Sedimentology, A.D.Miall (ed.); Canadian Society of Petroleum Geologists, Memoir 5 p.605-626.

Rust,B.R.,1979. Coarse alluvial deposits: in Facies Models, R.G.Walker (ed.); Geoscience Canada, Reprint Series 1, p.9-21.

Salazar-Jimenez, A., Frey,R,W., and Howard,J.D.,1982. Concavity orientations of bivalve shells in estuarine and nearshore shelf sediments, Georgia: Journal of Sedimentary Petrology, Vol.52, No.2, p.565-586.

Schmidt,V. and McDonald,D.A.,1979. The role of secondary porosity in the course of sandstone diagenesis:in Aspects uf Diagenesis; Society of Economic Paleontologists and Mineralogists, Special Publication 26, p.175-207.

- Williams,P.F., and Rust,B.R.,1969. The sedimentology of a braided river: Journal of Sedimentary Petrology, Vol.39, p.649-679.

Wilson,M.D., and Pittman,E.D.,1977. Authigenic clays in sandstones: Recognition and influence on reservoir properties and paleoenvironment analysis: Journal of Sedimentary

Petrology, Vol.47, No.1, p.3-31.

Winn,R.D.,Jr., Stonecipher,S.A:, Bishop,M.G.,1984. Sorting and wave abrasion: Controls on composition and diagenesis in lower Frontier sandstones, Southwestern Wyoming: American Association of Petroleum Geologists Bulletin, Vol. 68, No. 3 , p. 269-284.

Wolf,K.H., and Chilingarian,G.V.,1976. Diagenes is of sandstines and compaction: in Compaction of Coarse-Grained Sediments, II. Developments in Sedimentology 18B, G.V.Chilingarian and K.H. Wolf (eds.). Elsevier, p.69-444.

Young,F.G.,1974. in Use of sedimentary structures for recognition of clastic environments, M.S.Shawa (ed.); Canadian Society of Petroleum Geologists, 66 pp..

Young,F.G.,Myhr,D.W. and Yorath,C.J.,1976. Geology of the Beaufort-Mackenzle Basin; Geological Survey of Canada, Paper $76-11$. 


\section{Appendix 1}

\section{Stratigraphic Tops}

Tops of the formations and members of the Parsons Group dnd Husky Formation are given. These values form the basis of the lsopach maps presented in this thesis. Contacts were picked Erom gama ray/sonic logs,gama ray/neucron or densicy logs,SP,DIL logs or sample logs(Canstrat) in descending order of preference. Information was augmented with core data where possible. Depths are given in metres and feet (in parenthesis). A question mark appearing besiae a value indicares a questionable pick.

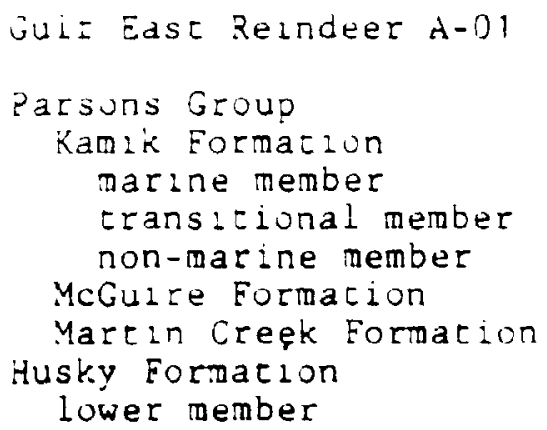

$2080.6(6826)$

$2238.8(7345)$

$2366.5(7765)$

$2505.5(8220)$

$2529.8(8300)$

$2560.9(8402)$

$2642.0(8668)$
$2658.5(8722)$

$2788.6(9149)$

$2880.4(9450)$

$2971.3(9750)$

$2993.1(9820)$

$2560.9(9957)$

$3109.0(10,200)$
$3237.0(10,620) ?$
$3264.4(10.710) ?$
$3291.8(10.800) ?$
$3322.2(10.900) ?$
$3334.5(10,940) ?$
$3401.6(11,100) ?$ 
Ula A-35

- Parsons Group not present due to eicher faulting or eosion

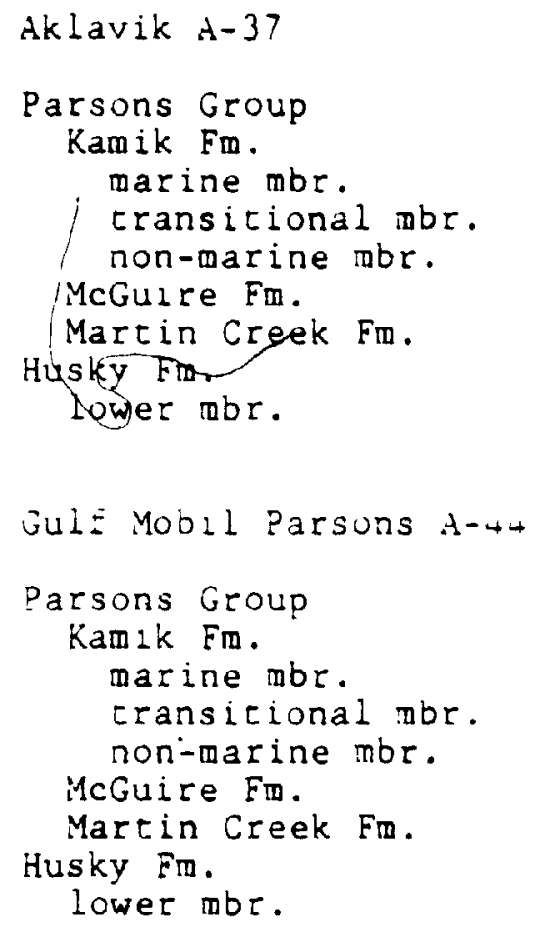

$887.0(2910)$
$993.7(3260)$
not present
$1017.1(3337)$
$1024.7(3362)$
$1094.2(3590)$
$1212.5(3978)$

$2905.7(9533)$

$3031.0(9944)$

$3116.9(9944)$

$3198.0(10,492)$

$3209.5(10,530)$

$3264.1(10,709)$

$3357.411,015$ :

Shell Unak B-11

Parsons Group

Kamik Fm:

marine mbr. cransitional mor.

$1179.6(3870)$

$1324.4(4345$ non-marine mbr.

McGuire Fm.

Martin Creek Fm.

Husky Em.

lower mbr.

$1541.7(5058)$

$1007.3(5275)$ ?

$1670.3(5480)$ ?

$1802.0(5912$

2008.6(6580)?

Gulf Mobil Siku C-11

Parsons Group

Kamik Fm.

marine mbr.

transitional mbr.

$2792.6(9162)$

non-marine mbr.

McGulre Fm.

Martin Creex Frt.

Husky Fm. (probable faulc,

lower mbr.

$2890.7(9484$

$2981.0(9780)$

$3015.1,9.892$

$3037.6(9966$

$3017.2 \div 10.076$

$3180.0 \cdot 10,+33)$ 


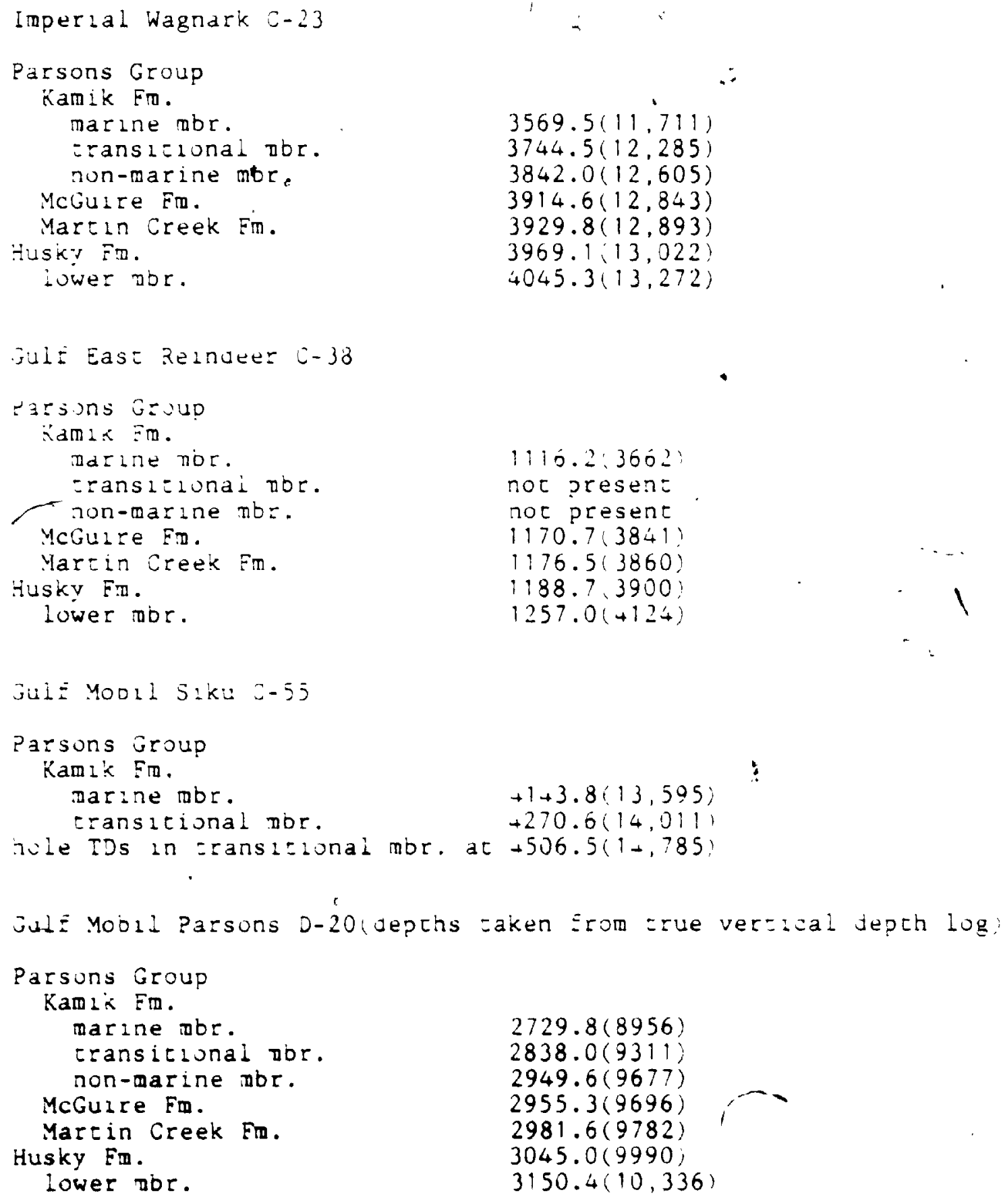

GulE Mobil Kamix $0-48$ 


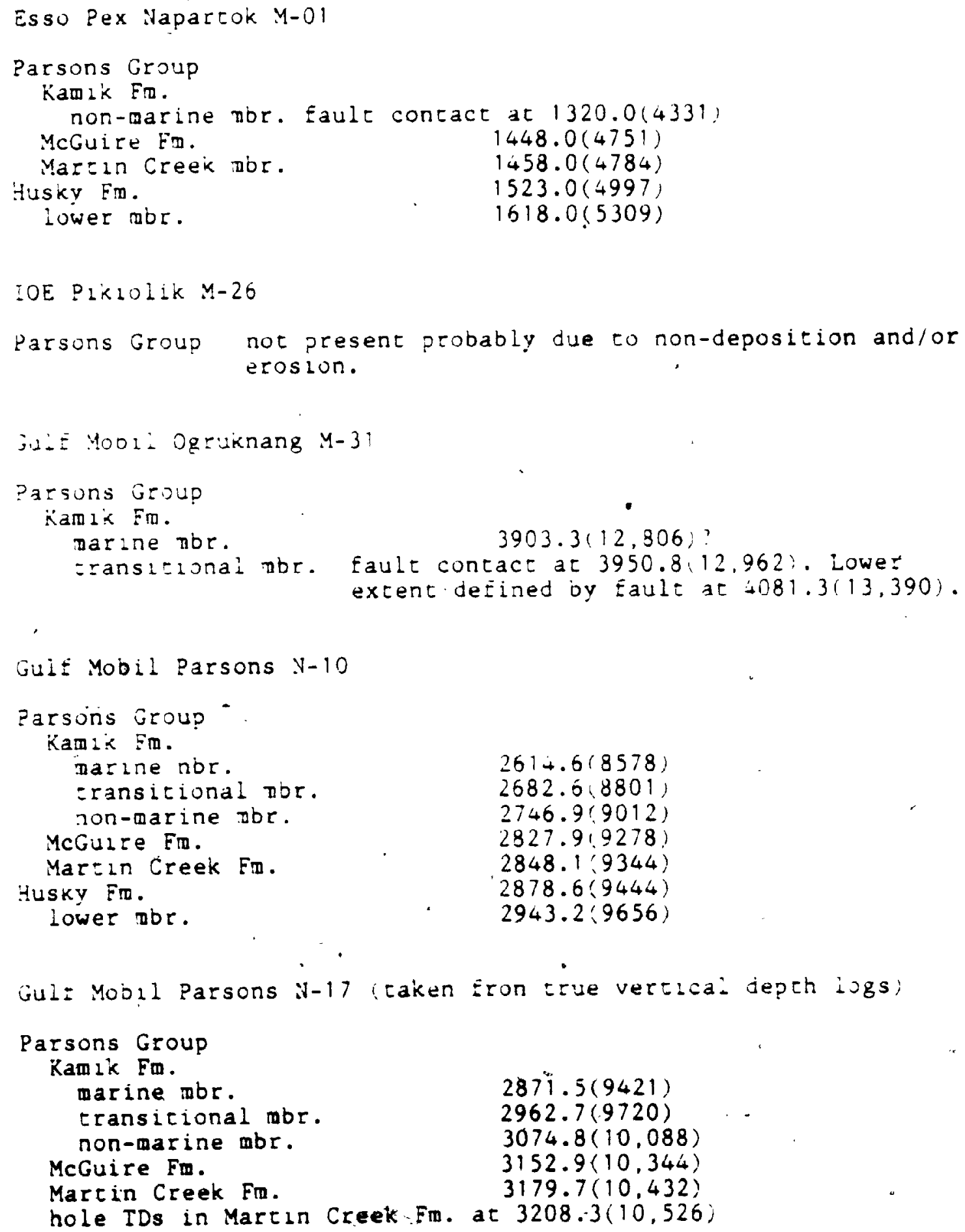


Guli Mobil Parsons F-09

Parsons Group
Kamik Em.

marine mbr.

cransitional mbr.

$2693.8(8838)$

non-marine mbr.

$2818.8(9248)$

$2906.9(9537)$

McGuire Em.

$2980.3(9778)$

Martin Creek Em.

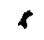

Husky Fm.

lower mbe.

$3005.0(9859)$

$.3055 .3(10,024)$

$3140.1(10,302)$

- Uniun Aklavik $E-17$

Parsons Grolip probably not present due to erosion andior nondeposition

LOE THK $\bar{\Xi}-18$

- Rarsuns Group
Kamik Fm.

narine nor.

Eransitional obr.

non-marine mbr.

McGuire Fm.

$3018.4(9903)$

$3045.6(9992)$

-3099.2(10,168);

hole TDs in McGuire Fm. ar 3140.1:10,322

Shell Vapoiak $5-31$

- Parsons Group

Kamik Fr.

marine mbr.

cransicional mor.

$759.0(2490)$

cion-marine mbr.

McGuire Fm.

Martin Creek Fr.

Husky. Fm.

lower mbe.

$824.2 \times 2704 ;$

$367.5(2846)$

$893.1: 2930)$

$901: 9(2959$

$913.2(2996)$

$981.2(3219)$

Gult Mobil Kamik F-38

Parsons Group

Kamik Fm.

marine mbr.

transitional mbr:

$3006.6(9864)$

$3102.3(10,178)$

non-marine mbr.

$3208.6(10.527)$

McGuire Fm.

Martin Creek Fm.

$3234.8(10,613)$.

Husky Fm.

$3261.4(10,700)$

lower mbr.

$3314.4(10,874)$

$3372.0(11,063)$ 


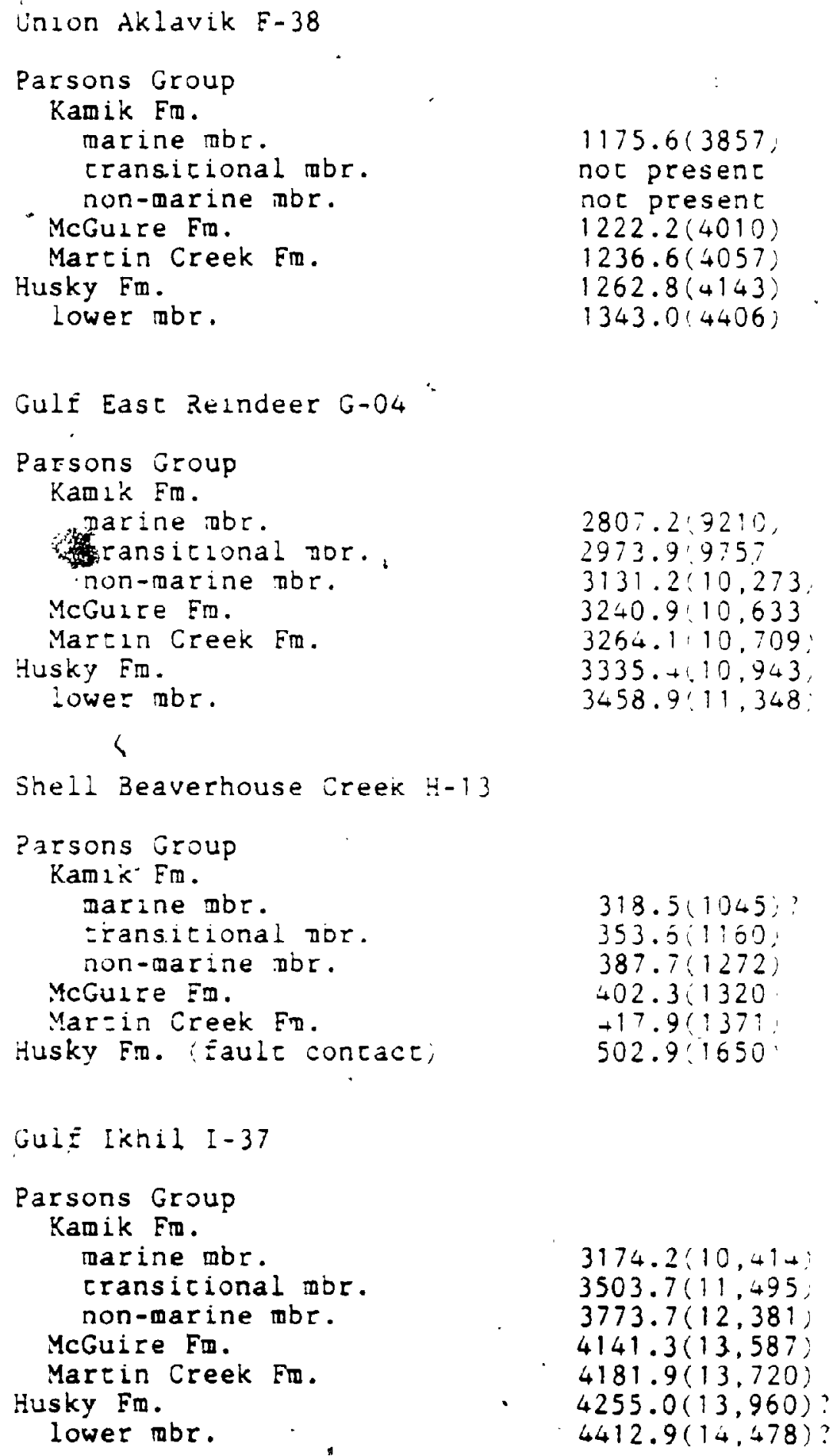




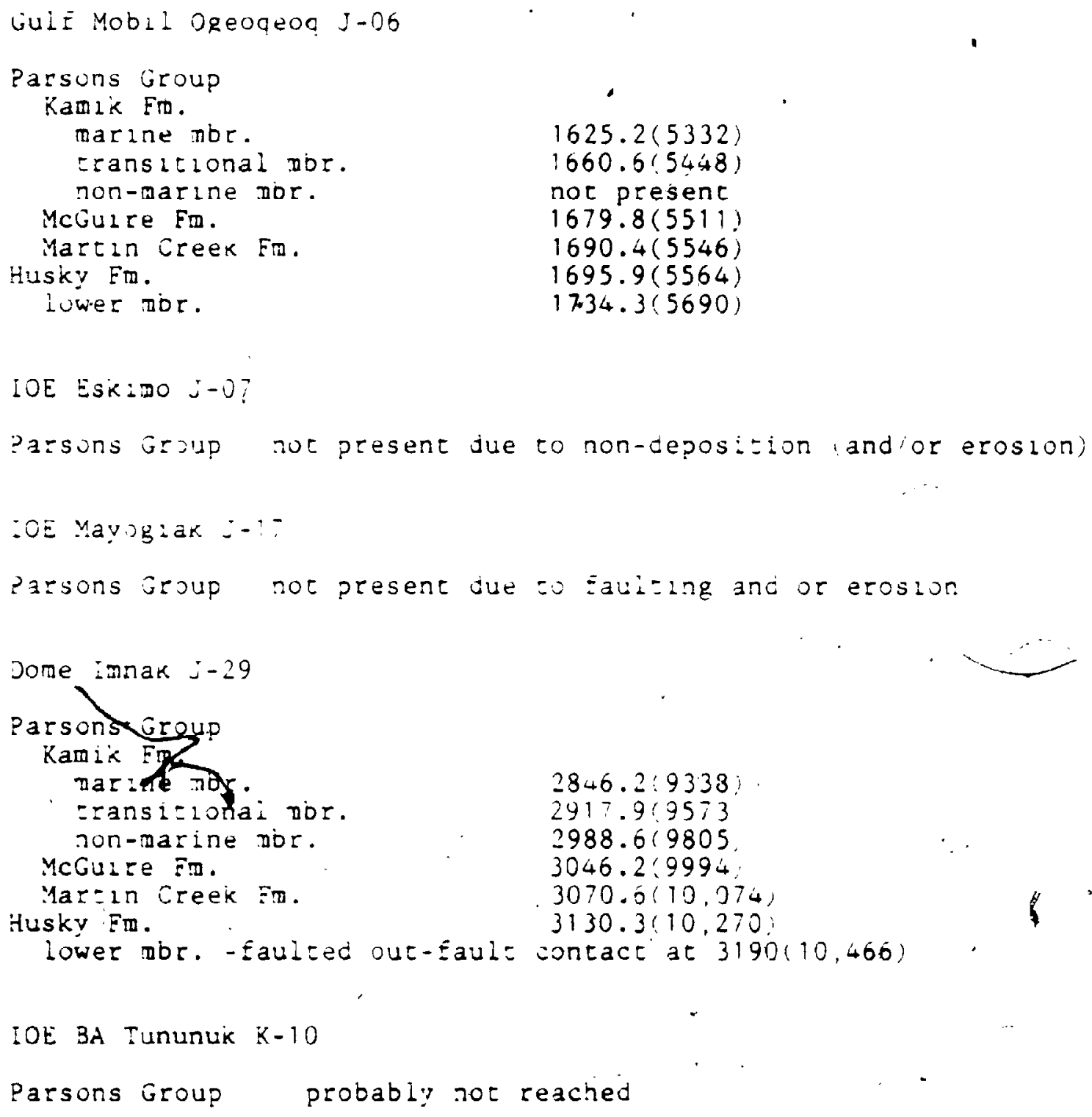




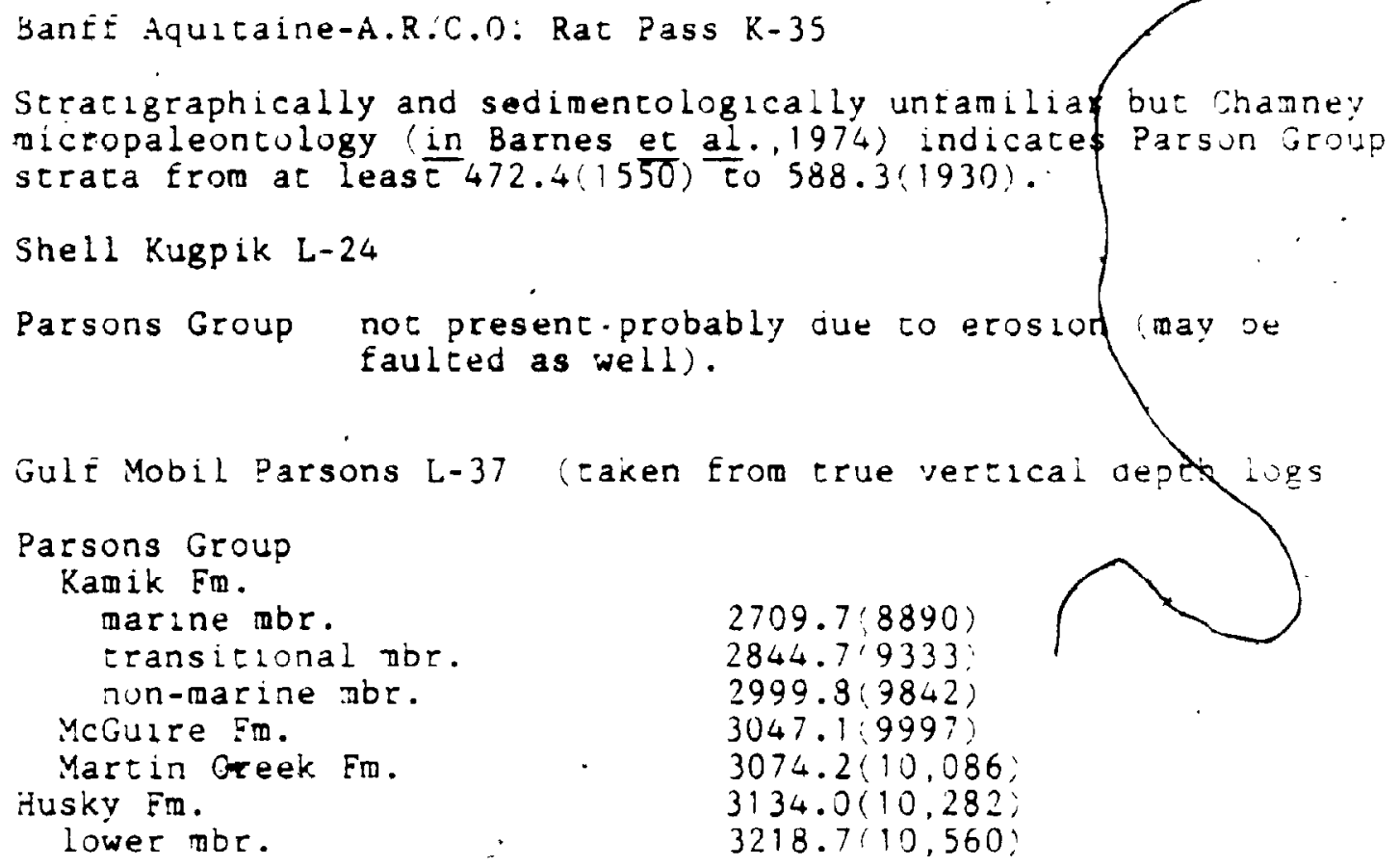




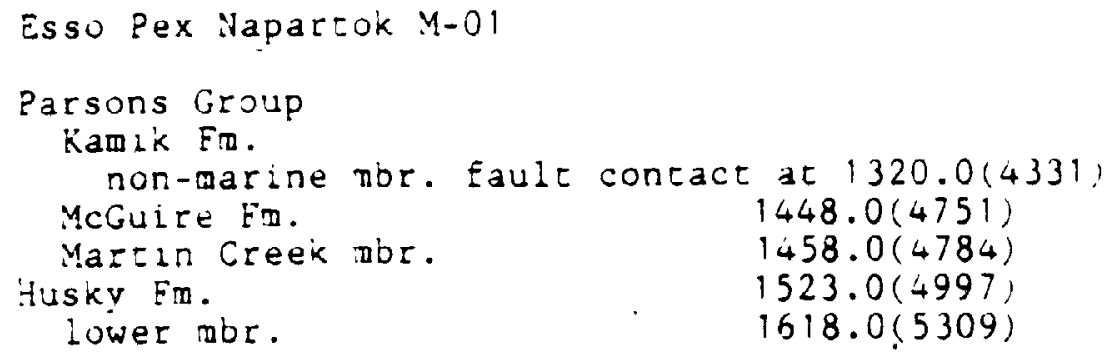


. Shell Kugpik $0-13$

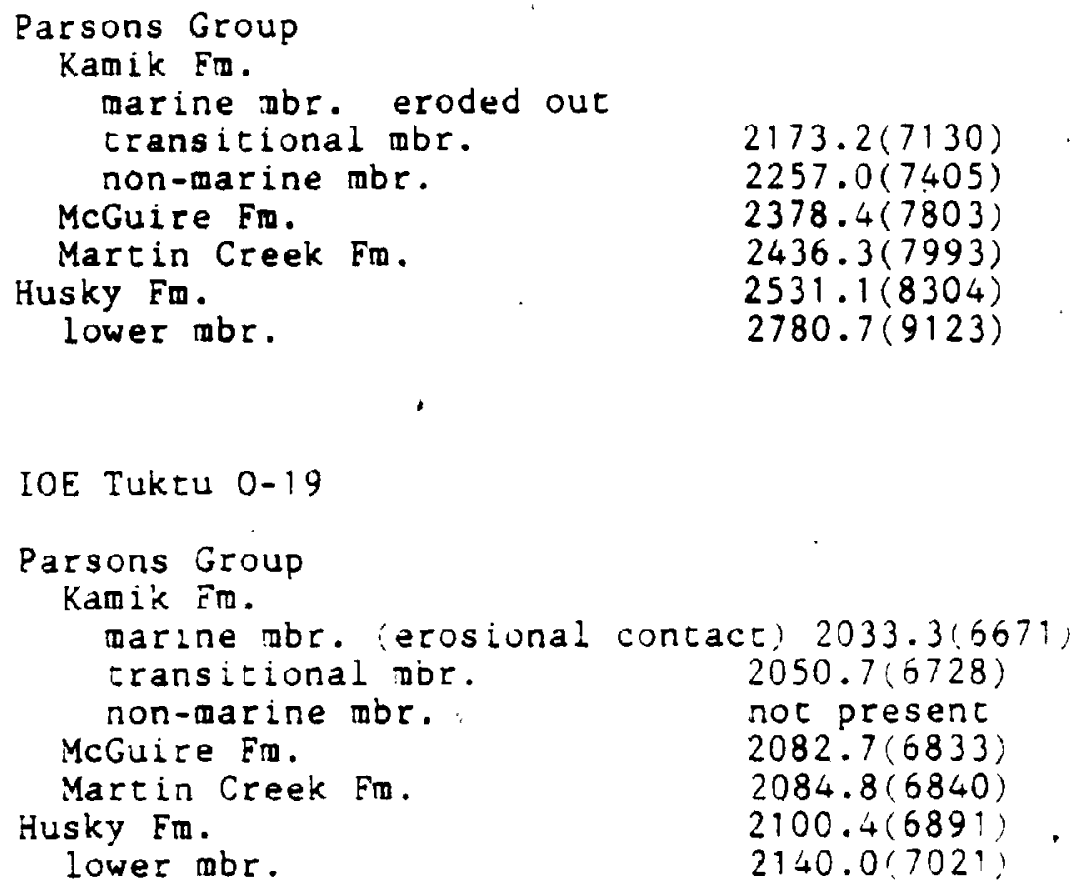

Shell Kipnik $0-20$

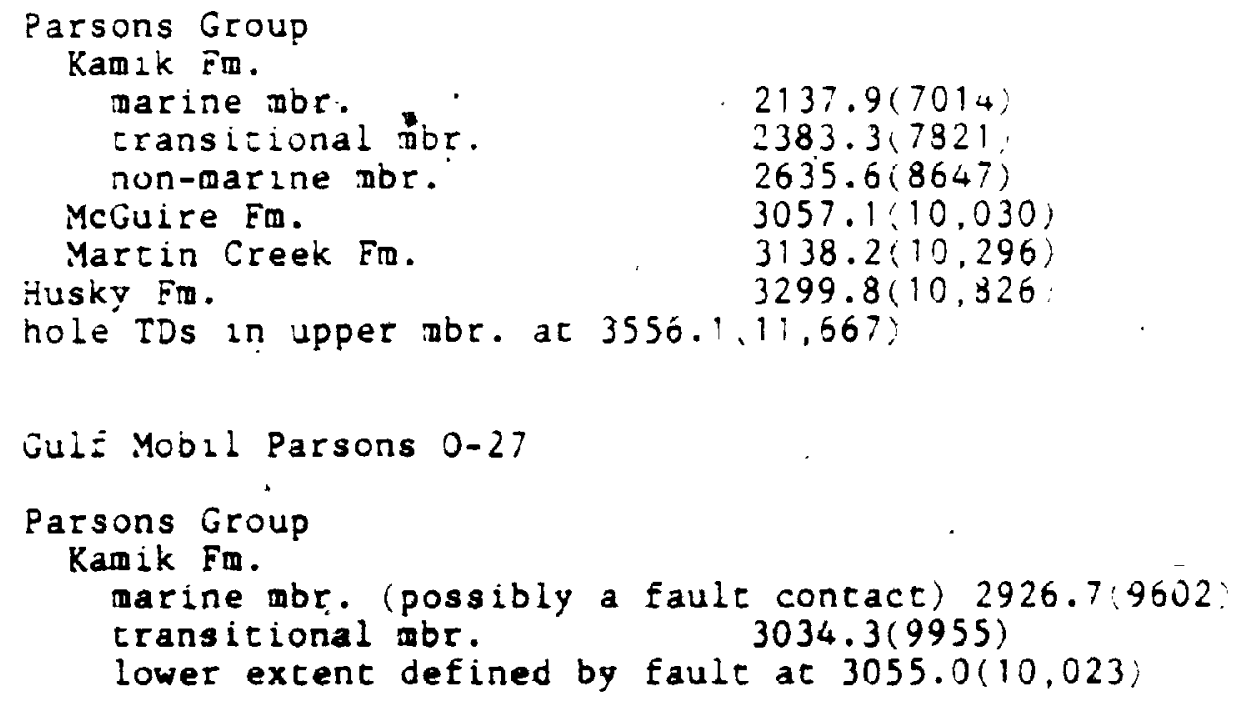




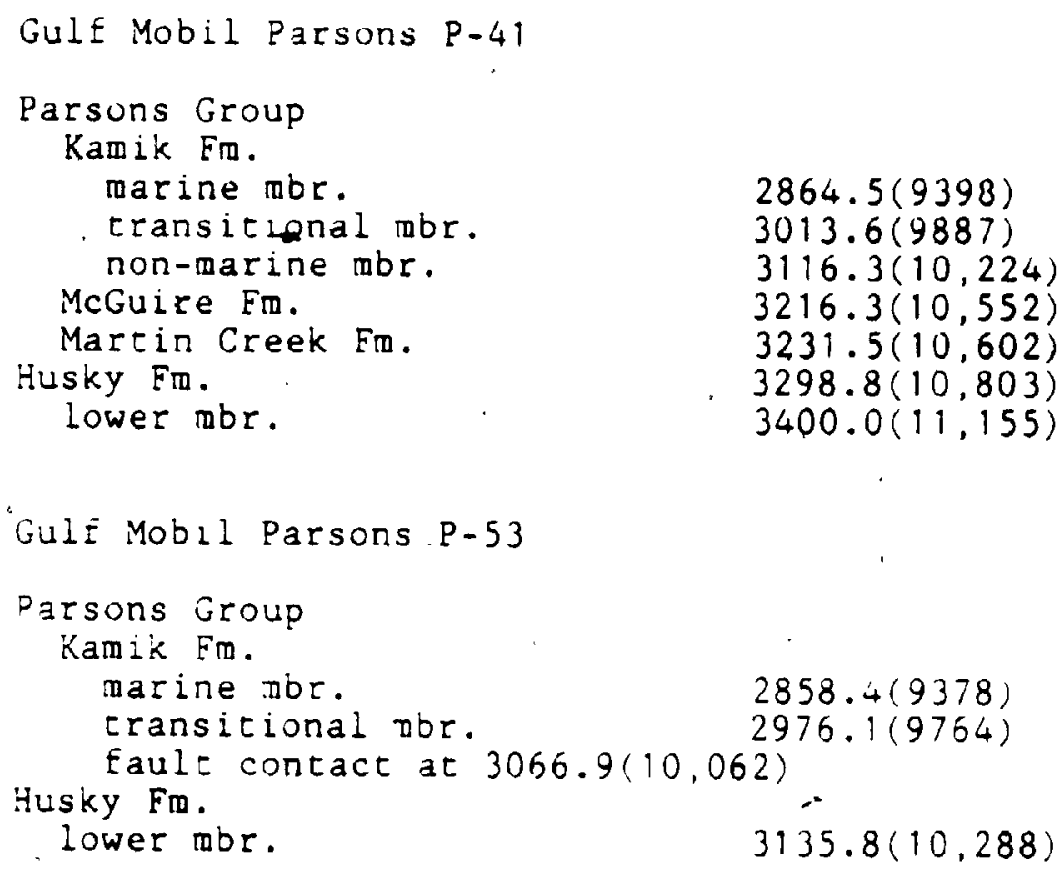

$969.9(3182)$

not present not present 1049.7(3444) not present $1053.1(3455)$ $1104.9(3625)$ 
Appendix 2

Subsurface Biostratigraphy

.East Reindeer A-01

Megaspore Identification by Sweet (in Brideaux et al., 1976. p.10) suggested an Albian age for the transitional member of the Kamik Formation (7544 - 7579 feet). This age suggested is questionable in light of the correlation of A-0l strata int, well-dated Parsons "Group rocks. Although caving hampered precise biostratigraphic dating benthonic Foraminifera indicate a possible Neocomian top at 4920 feet, (1900 feet above the Kamik Formation) according to Gulf Canada Resources (unpublished data).

Aklavik A-37

Benthonic foraminiferal work by Gulf Canada Resources (unpublished data) indicaces a Barremian to Valanginian age for strata encompassing Parsons Group rocks from 2100 to 3800 feet. An uncertain Berriasian age is assigned to rocks from 3800 feet to the Jurassic top at 3850 feet.

East Reindeer $\mathrm{C}-38$

Based on Foraminifera identification Gulf Canada Resources assigns a Barremian to Valanginian age to strata containing P.arsons Group rock frow 3350 to 3950 feet and a Berridsian age. to strata from 3950 to 4490 feet.

Siku C- 55

Benthonic foraminiferal work by Gulf Canada Resources 
assigns a Barremian to Valanginian age to strata Erom 11,430 . feet to bottom in the Kamik Formation at 14,785 feet.

Pikiolik E-54

The Parsons Group strata which probably occur in this well are cored from 8,498 to 8,506 feet. Using dominanty foraminiferal assemblages, Chamey, Jeletzky and Pedder (ín Brideaux e $\underline{a} \underline{1} ., 975$ p.12) assign these rocks to the Cretaceous-Jurassic boundary, while Brideaux (in Brideaux et al.., 1976, p.4) using palynomorphs assigns a Hauterivian to Aptian, possibly no younger than Barremian age to the same strata. In this paper, the cored interval is correlated with, the upper marine member of the Kamik Formation, "of approximately early Hauterivian age.

t.

- Parsons F-09

Mainly by palynomorphs Brideaux (in Brideaux et al., 1975 , p.4) assigned an Early Cretaceous age, probably Barremian to Hauterivian to strata cored from 9315 to 9375 feet. In this study, the cored interval is correlated with the transitional member of the Kamik Formation, probably of early Hauterivian or late Valanginian age. Elsewhere, Brideaux (in Brideaux et al. 1975, p.4) assigned a similar Barrenian to Hauterivian age to - strata cored at 9817 to 9847 feet. Gunther (in Myhr and Gunther 1974. p.26) also using palynomorphs dated the same racks as late Neocomian (Hauterivian or Barremian). These rocks correlate with the McGuire Formaton of early to middle Valanginian age elsewhere, suggesting an erroneous biostratigraphic interprection

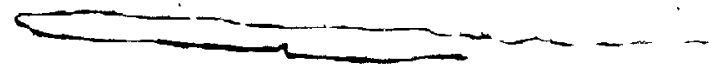


by Brideaux and Gunther in the lower core (see Dixon, 1982, p.18).

Benthonic Foraminifera studied by Gulf Canada Resourits (unpublished data) indicate Neocomian age for strata Erom ?.i8. feet to the top of the Jurassic at 10.220 feet. Parsons ifr is. rocks are present from 8838 feet to 10,024 Eeet.

East Reindeer G-04

Palynoriorph and mollusc studies by Brideaux and Jeletzky in Barnes et al., 1974, p.7) and palynomorph studies by Sweet in Brideaux et al., 1976, p.10) indicate ages of Early Cretaceous for strata cored from 9560 to 9591 feet. Swet. (요. ㄷi․) suggested an Albian age which, in the light of corcrelations of this cored interval with the marine member of the kamil Formation, elsewhere known to be Hauterivian in age, may be incorrect.

Benthonic foraminifer'al and palynomorph work done by Gulf Canada Resources (unpublished data) assigns. a Barremian to Valanglnian age to strata from 7567 to 10,240 feet(containing the upper Kamik Formation), and a Berriasian age to strata from 10,240 feet to the top of the Jurassic at 11,110 feet. The base of the Parsons Group strata occurs at 10.943 feet.

Beaver House Creek $\mathrm{H}-13$

Benthonic Foraminifera studied by Gulf Canada Resources 
suggest a Neocomian age for strata from surface to the Jurassic top at 1850 feet. Parsons Group strata are present in the hole from approximately 1045 feet to 1650 feet.

Ikhil I-37

Benthonic foraminiferal and other wicrofossil work by Gulf Canada Resuurces indicates straţa from $9140^{\circ}$ to 14.550 feet are of Harrenian to Berraisian age. Parsons Group rocks are present in the hole from 10,414 feet to 14,478 feet.

:1ayogiak $\mathrm{J}-17$

Using palynomorphs, Foraminifera and related microfauna, Brideaux, Chamney and, Pedder (in Barnes et al., 1974 pp. 14-16) and Jeletzky (in Brideaux et al... 1975, p.7), using pelecypods - assigned a (Late Jurassic?) Early Berriasian age to strata cored at 8850 feet. Rocks directly overlying this cored zone are lichostratigraphically similar to post-Parsons strata. Brideaux, Chamey and Pedder tentatively assign a Late Cretaceous age to rocks at 7,146 to 7,163 feet. Consequently, Parsons Group strata are thought to be absent by either faulting or erosion/nondeposition.

\section{Rac Pass K-35}

With palynomorphs, Brideaux (in Barnes et al.. 1974, pp. 711) assigned strata from at least. 1,550.to 1,930 teet a preHauterivian-Neocomian age. These beds are stratigraphically and lithologically not comparablie to typical parsons Group rocks nearby and thus make the ages proposed suspect.

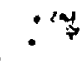


Pikiolik M-26

Strata directily overlying Paleozoic carbunates here ir assigned an Aptian to Barremian age Erow 5.546 to 5.572 feet an: an Aptian age from 5.572 to 5.576 feet by Chamey in Brbdeat. et al., 1975, p.6). Con'sequently, no Parsons Group $i=t a t a$ belleved present in the wellhole.

\section{Parsons $\mathrm{N}-10$}

Dinoflagellate cysts identifled by Brideaux and Yynt : Indicate a Valanginian to Haucerislan age Eur rocks Erom $i, 90:=$ 9.325 feet (mainly Kamik Formation) and a Berridsian age: Lowermost McGuire Formation. Martin Creek Formation.and uppe: Husky Formation from 9,325 to 9,550 feet.

Benthonic Foraminifera and palynomorphs studied by iul: Canada Resources (unpublished data) date strata E t t approximately 7,230 feet to the top of the Jurasste a 9.010 iee: as of Nieocomian age.

Kugpik $0-13$

Palynomorph and pelecypod identifications by Brideaux 17.1 Jeletzky (in Brideaux et al., 1976. Pp. 4-6) place strata Eron 7,137 feet to 7,610 feet as Early Cretaceous in age, and strata frow 7,876 to 8,025 feet wost likely as Valanginian in age. Less well defined strata from $8,160^{\circ}$ to 8,320 feet are assigned a Late Jurassic to Early Cretaceous age by Brideaux and Jeleizky 
(op. clt.). Parsons Group rocks extend Erom 7130 feet to 8304 feet.

Tuktu $0-19$

Brideaux, Chamney and Pedder (in Barnes ęt al., 1974, p. 16) ised palynomorphs, foraminifers and associated microfaunas to jate the complex strata in this hole. They assigned"a JurassicLretaceuus boundary age to strata which in this report, is oelleved to be post-Parsons rock, elsewhereof Barremian and younger age. They, as well, assigned a Late Jurassic age to sured strata from 6,883 to 6,913 feet. In contrast, palynomorph work by $3 r$ ldeaux ( 1 n Brideaux et al. 1976," p.4) assigns the same strata $(6,810$ to 7,050 feet) an Early Cretaceous (Hauterivian to Albian) age. Brideaux (op.cit.) assigned a Late Jurassic, Early Tithonian age to strdta immediately below the above mentioned Interval.

The ambiguous nature of the biostratigfaphic work attempted In this well makes age assignments difficult. In this study, the stracigraphy of this locality is based upon the lithology, log responses and the correlation of typical stratigraphic chafacteristics to neighbouring wells.

Kipnik $0-20$

Palynological and foraminiferal work by Gulf Canada Resources (unpublished datal assigns strata from 5,190 to 10,700 feet as Early Cretaceous. no younger than Barremian'in age. Parsons Group rocks extend from $7014^{\circ}$ feet to 10,826 feet in this 
we 11 .

$$
\text { East "Reindeer P-60 }
$$

Gulf Canada Resources (unpublished data) assigns an Aptian to Valanginian age to strata Erom 2,550 to 3,500 feet and a Berriasian age to strata from 3,500 to 4,560 feet. Parsons Group rocks are present from 7014 to 10,826 feet in this well. 


\section{Appendix 3 \\ $X-r a y$ Analyses}

Sample Deptin ( $m$ ) Montmorillonite Illite Kaolinite Chlorite $x-10$

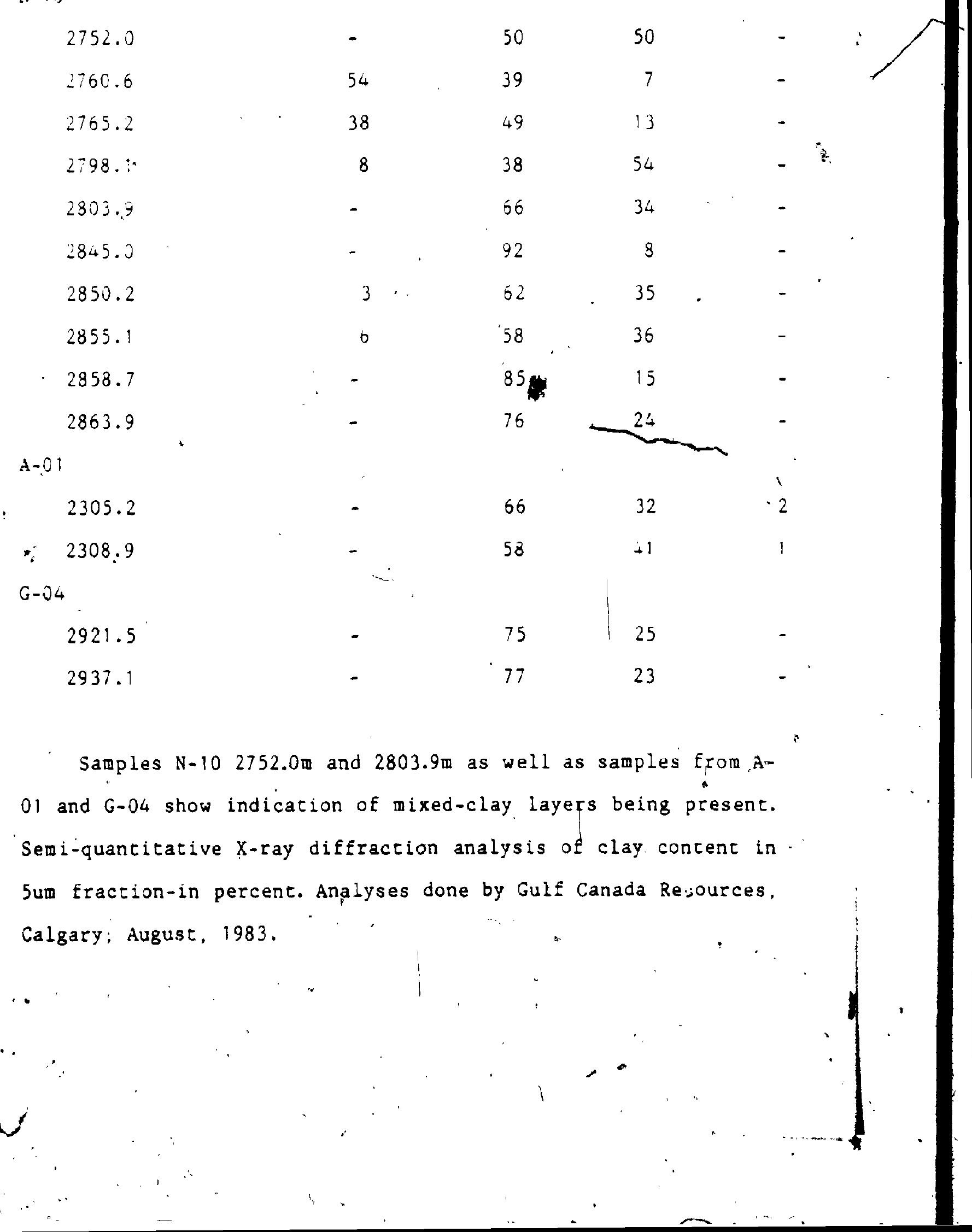




\section{IOE TUKTU $0-19$}
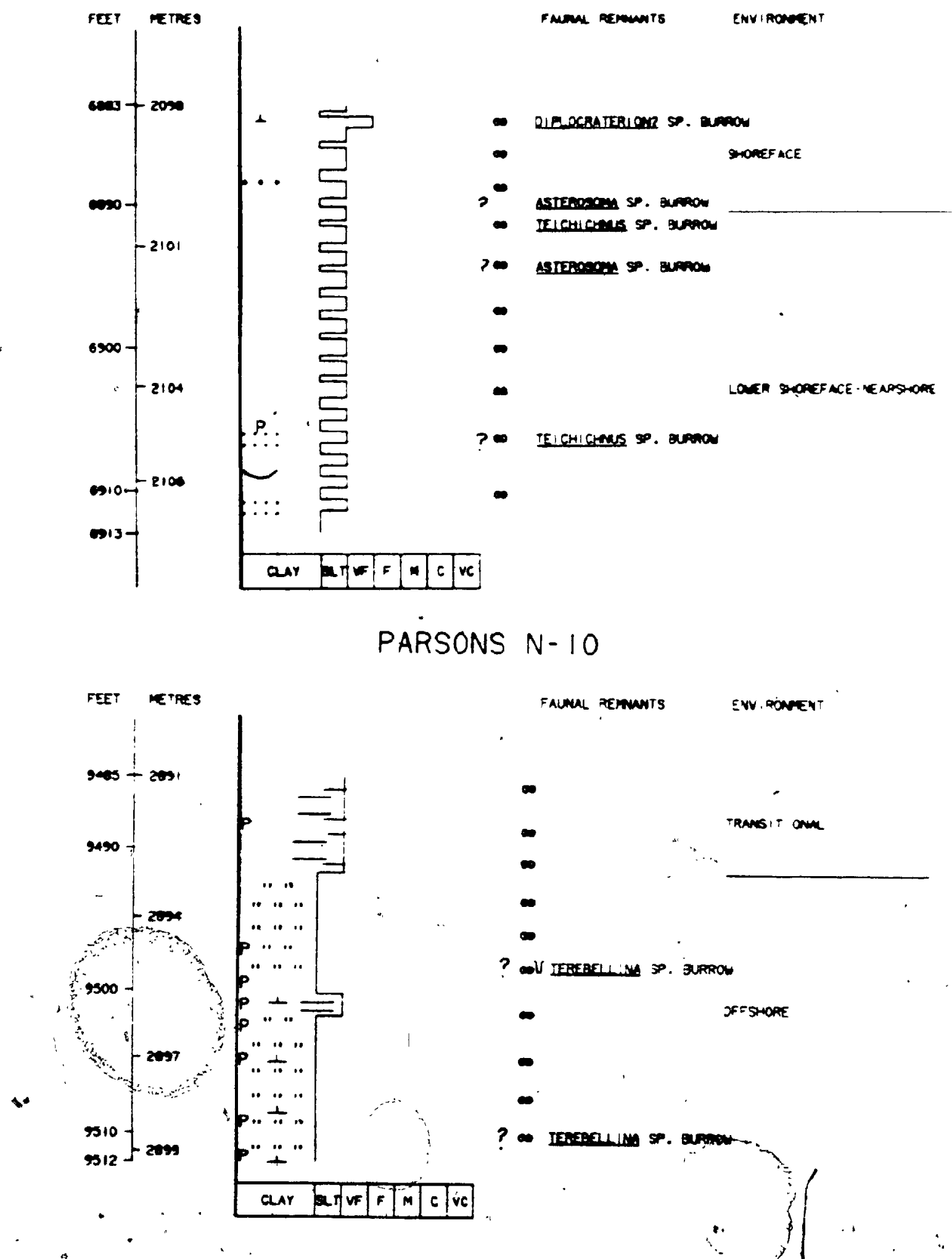

Figure 41. Detailed graphic displav of CopejaE Tuktu $0=198$ patsons $x-10$

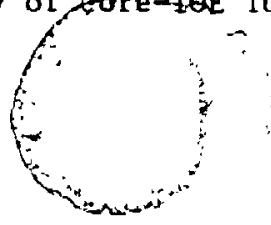


TULLUGAK K-31

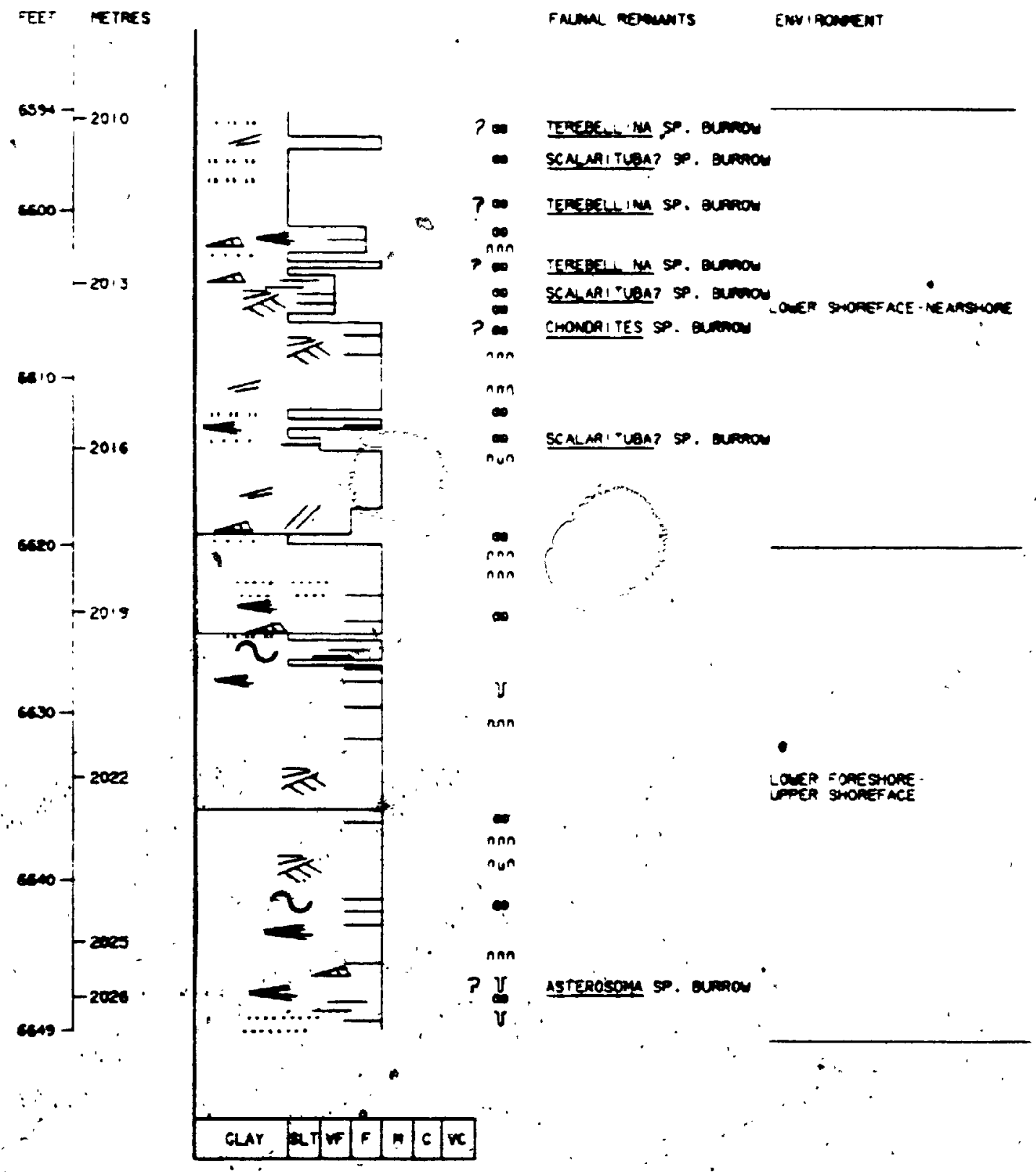

Figura 43. Detalled graphic display of core-Tullugak K-31 


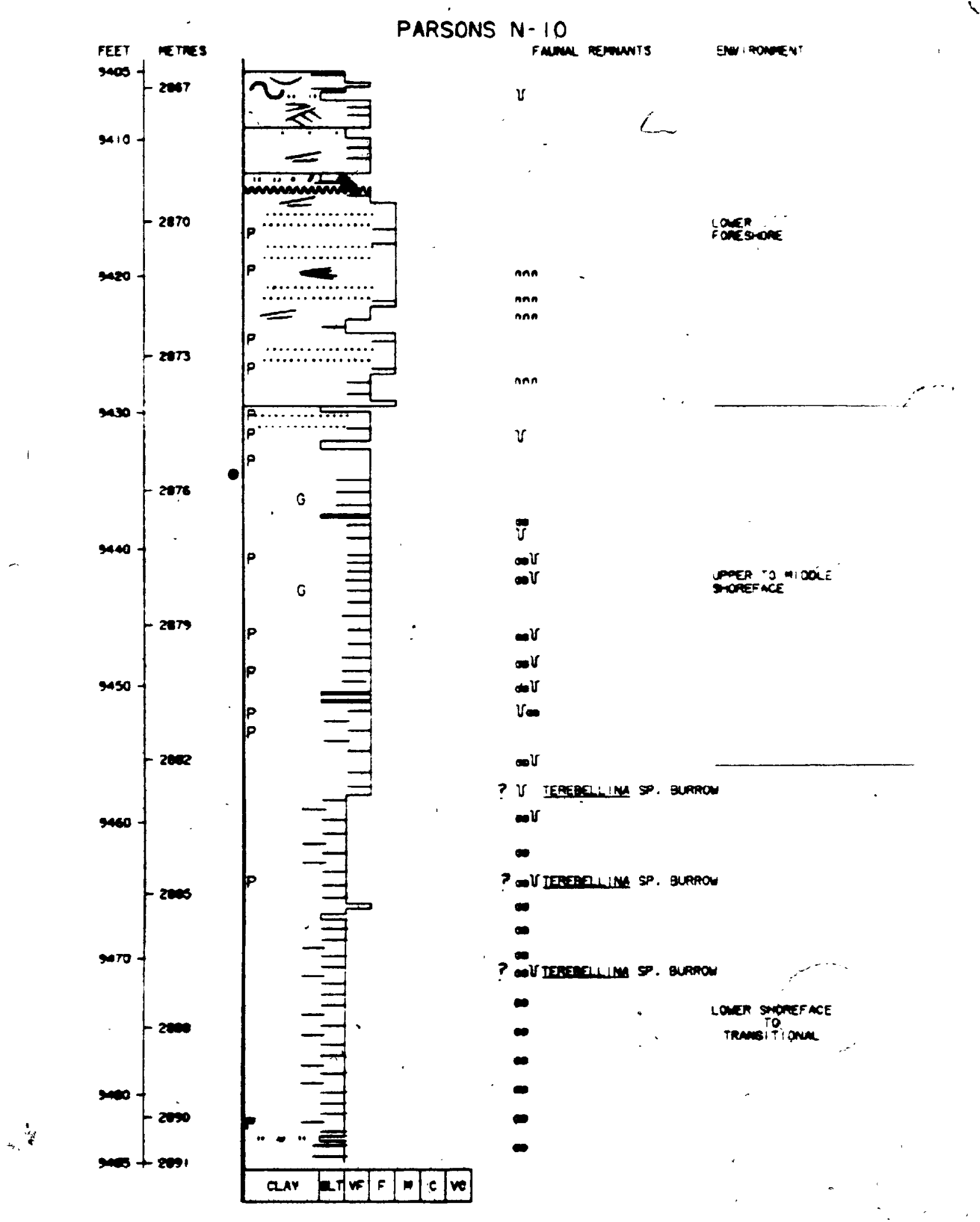

Eigure 43. Detalled graphic display of core-Parsons $N-10$ 


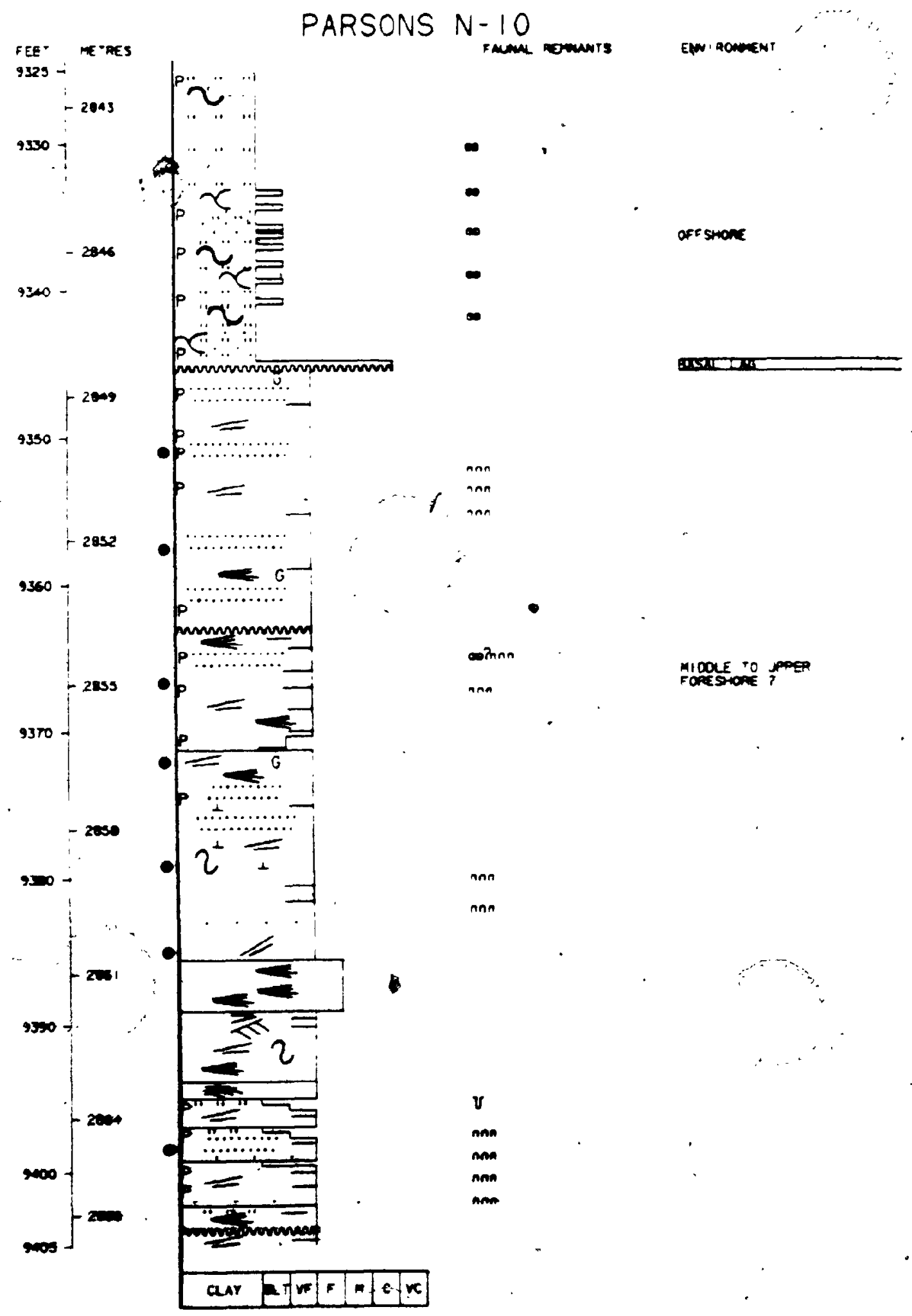

Figure 44. Detalled graphic display of core-Parsons $\mathrm{N}-10$ 
PARSONS F-O9

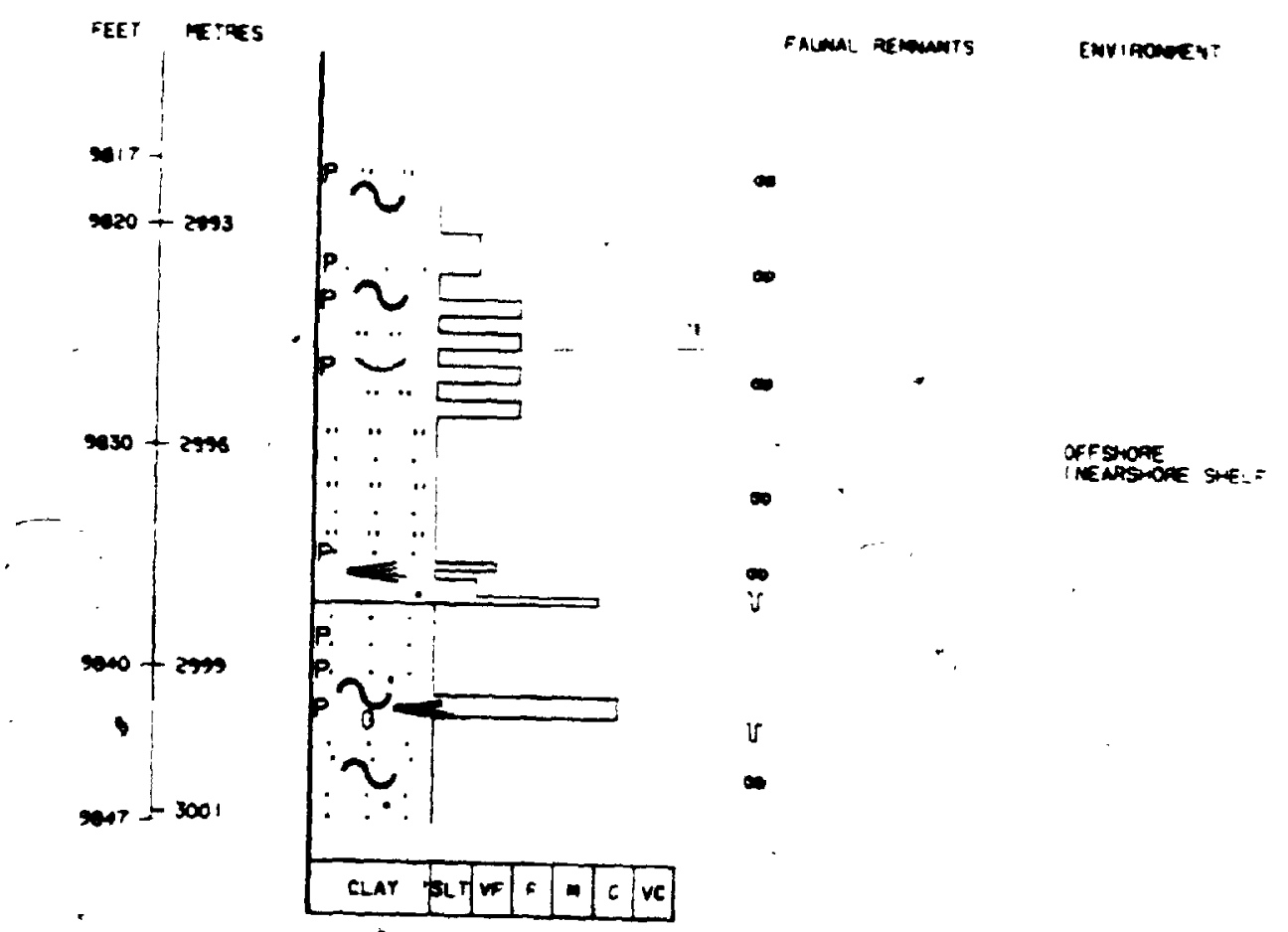

Eigure 45. Detalled graphic display of core-Parsons F-09

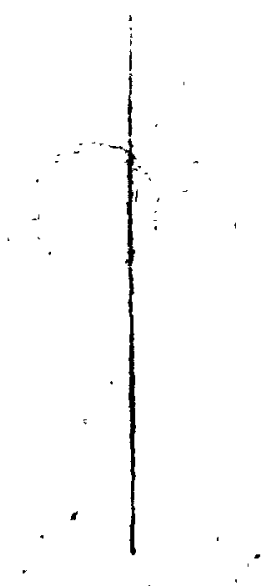


PARSONS $N-10$

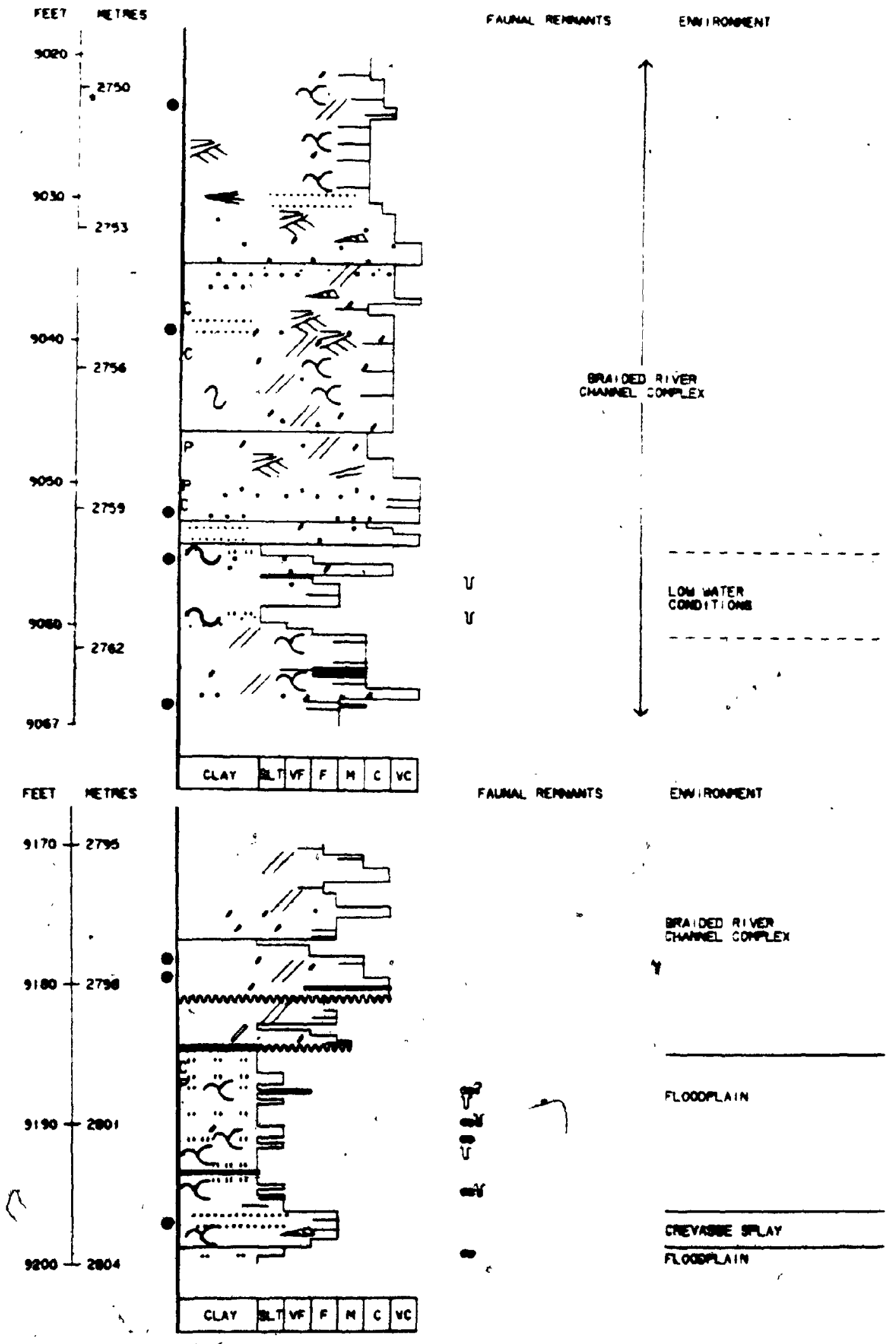

Figure 46: Detalled graphic display of core-Parsons V-10 
PARSONS L -43
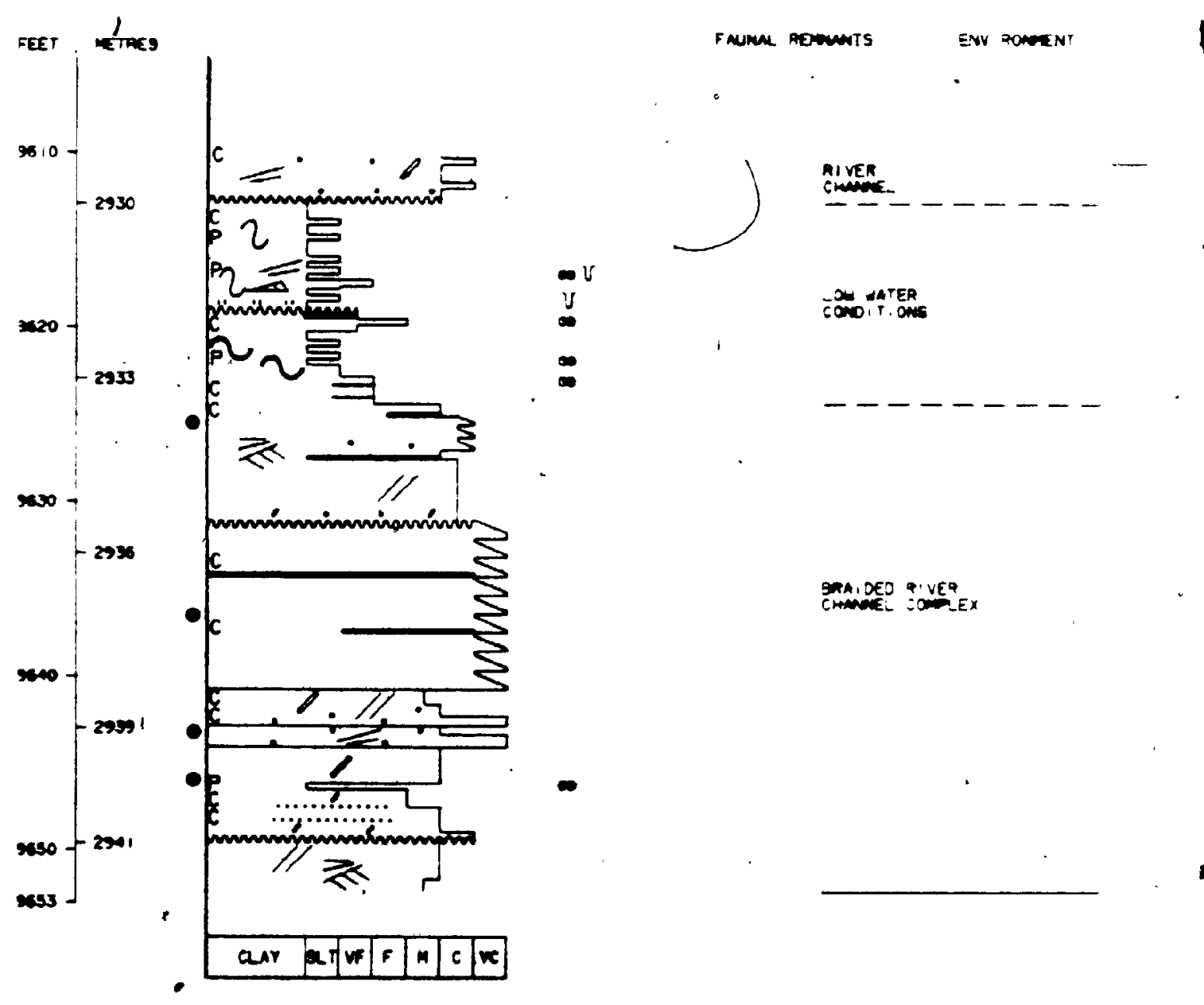

Figure 47. Detailed graphic display of core-Parsons L-43 
WAGNARK $C-23$

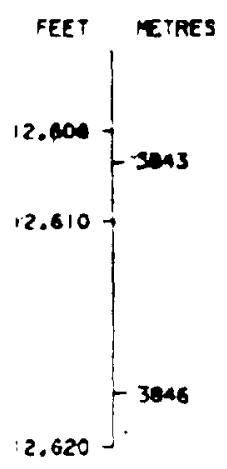

saunue RERmuirs

ENV RONUENT

LOA

EAIDED aI ve

aring?

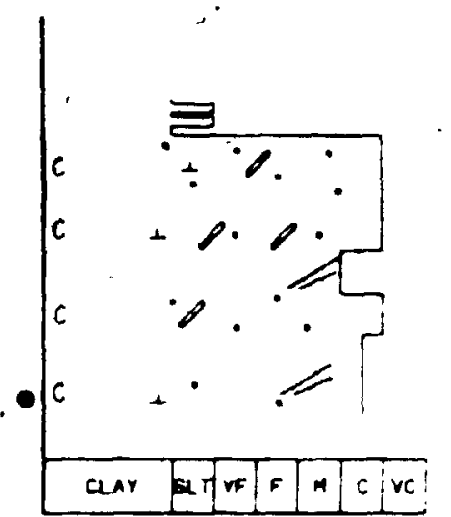

IKHIL I-37

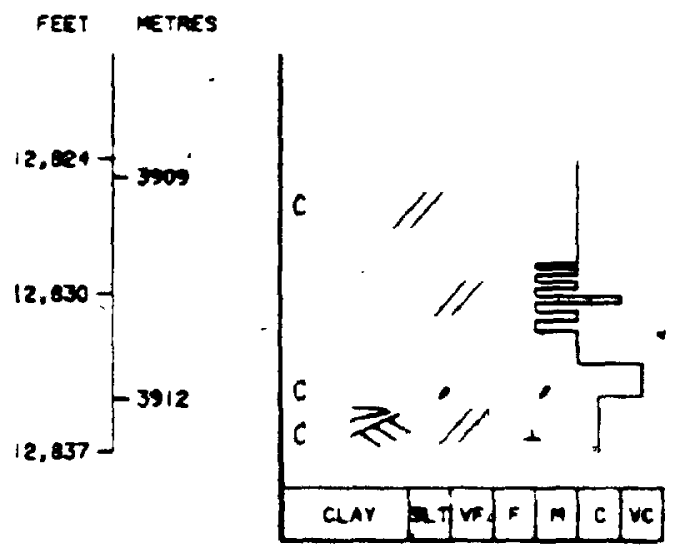

Faunal acmonts

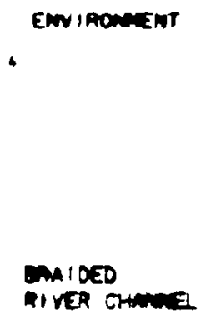

Figure 48. Detailed graphic display of core-Wagnark C-23\&Ikhil I-37 


$$
\text { SIKU E-2I }
$$

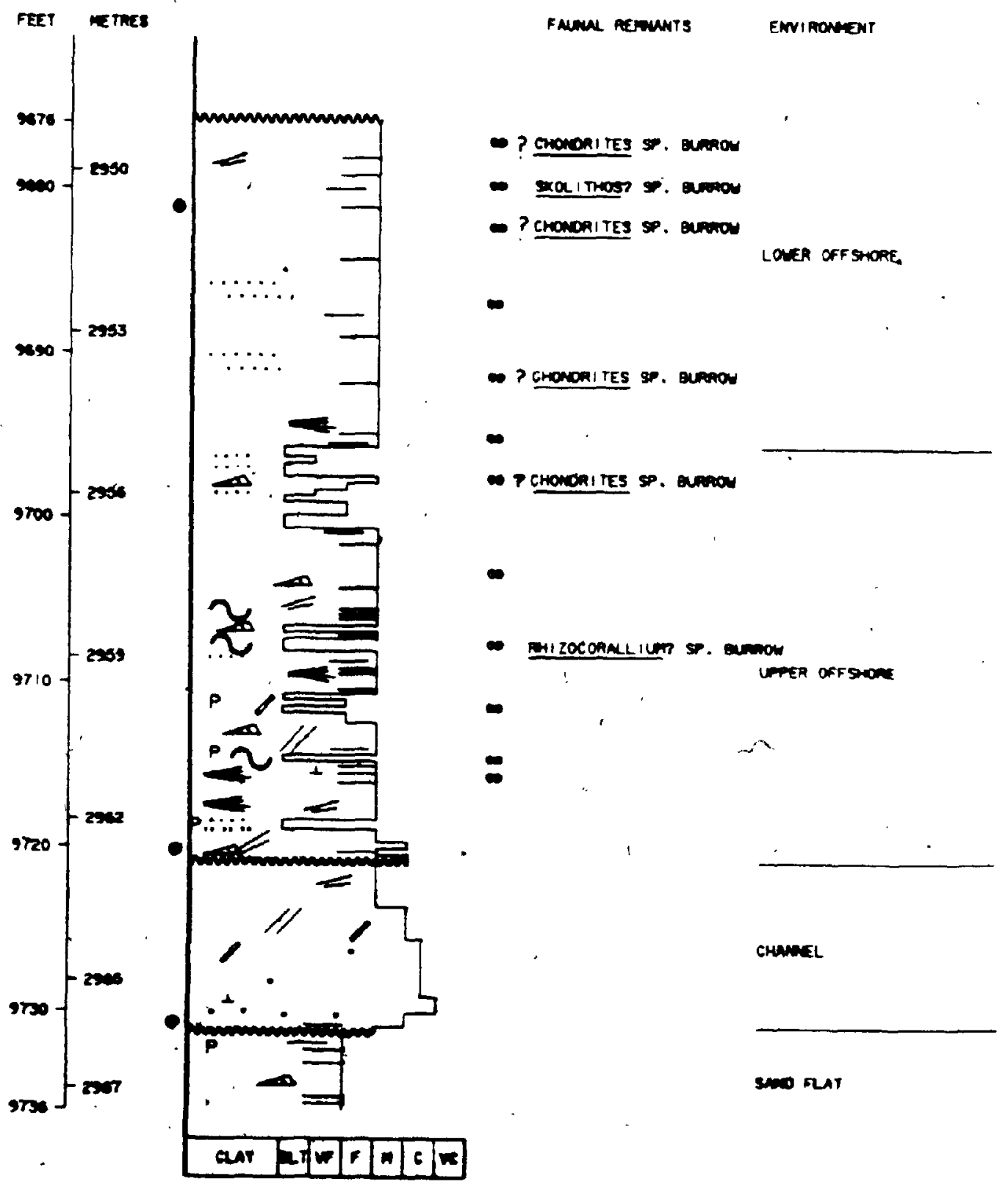

Figure 49. Deta1led graphic display of core-Siku E-21 


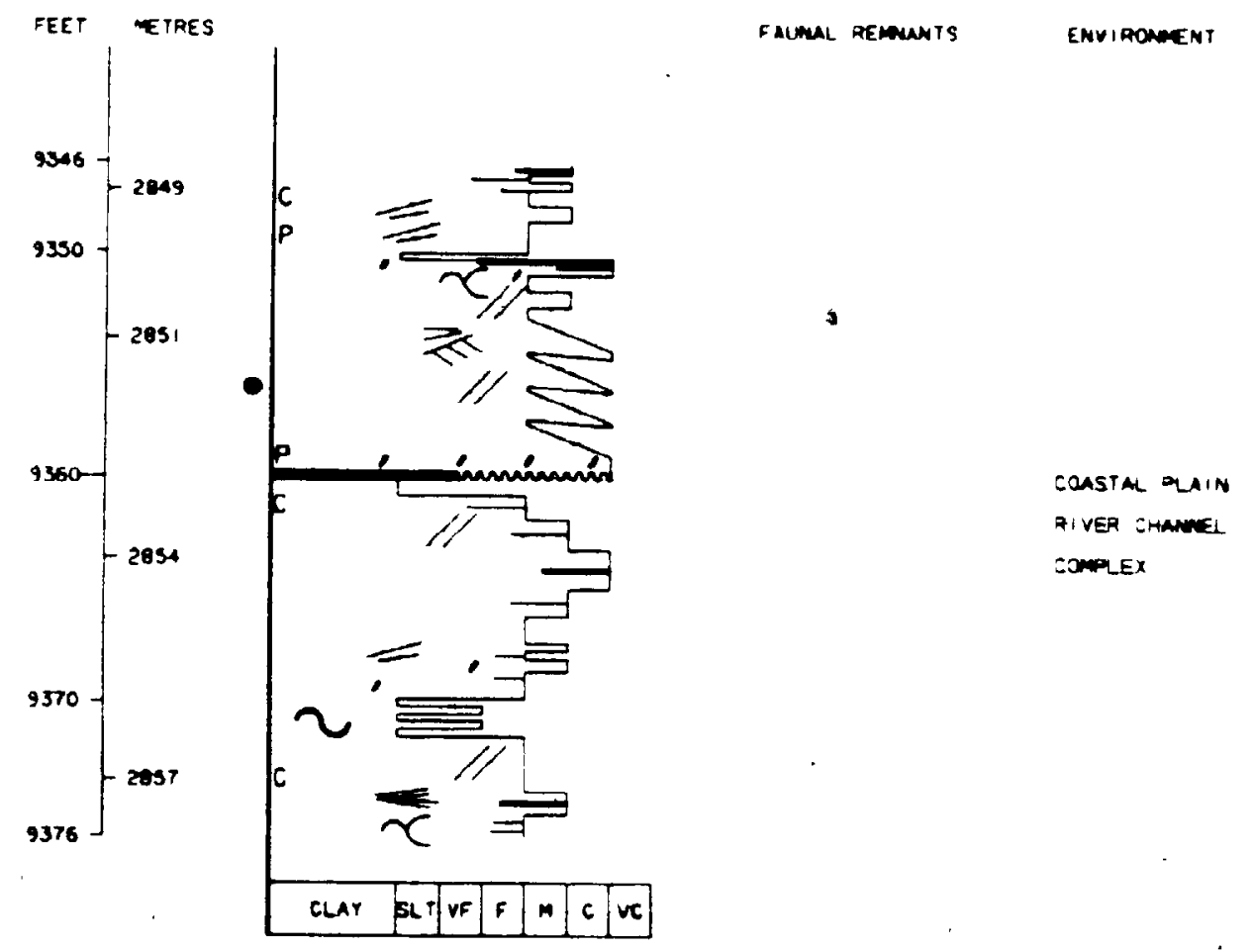

SIKU E-2।

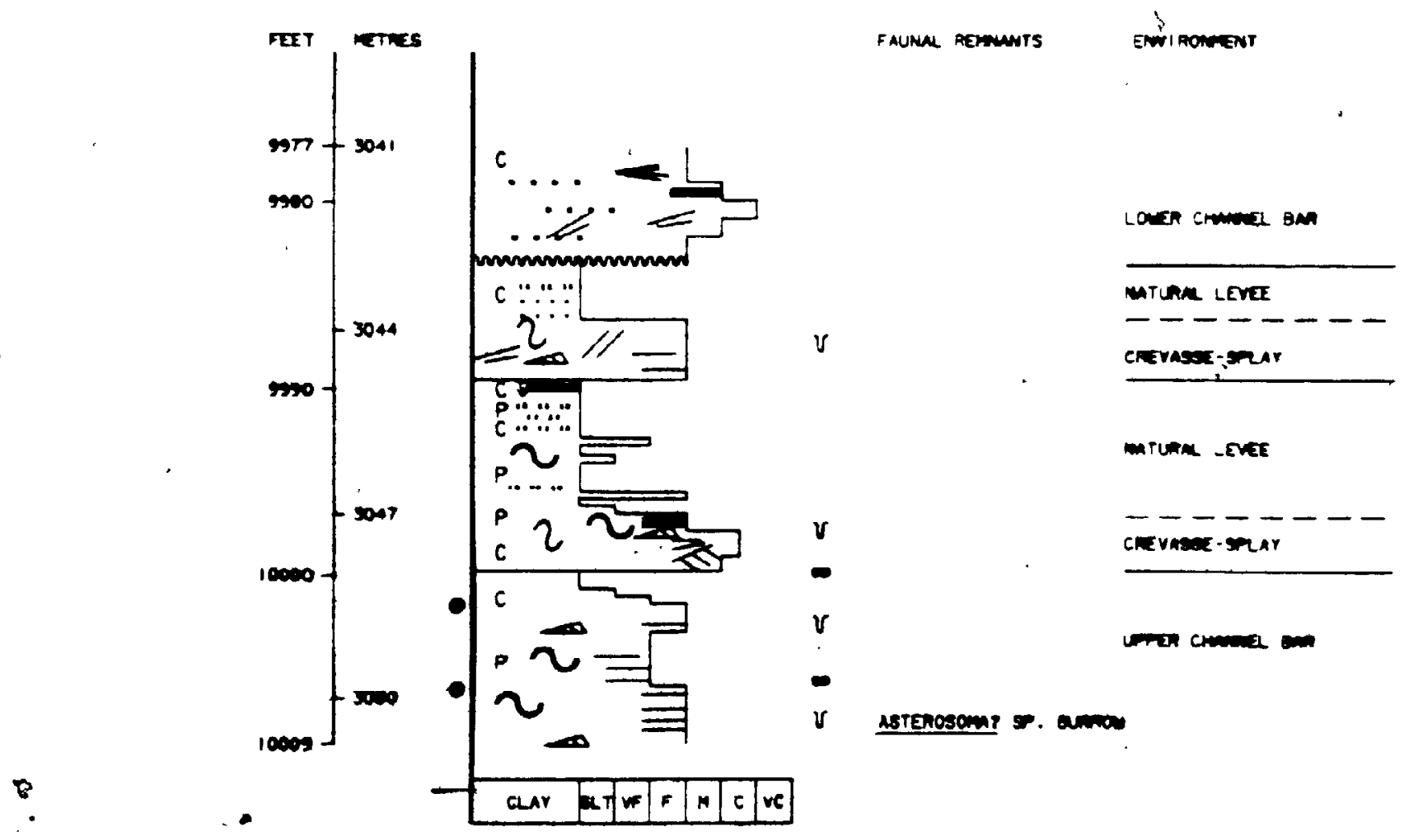

Figure 50. Detalled graphic display of core-Parsons L-43dSiku E-2l 


\section{PARSONS F-09}

FEET NETES

Faunu remunis

ENI ROMEENI '

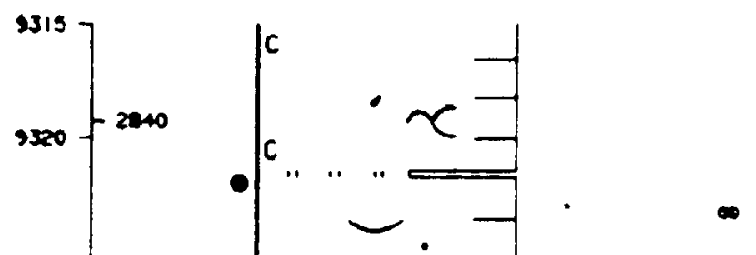
Sen? ?.

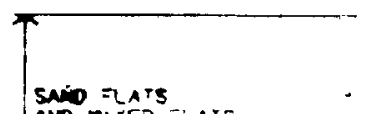

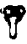

$\infty$

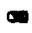
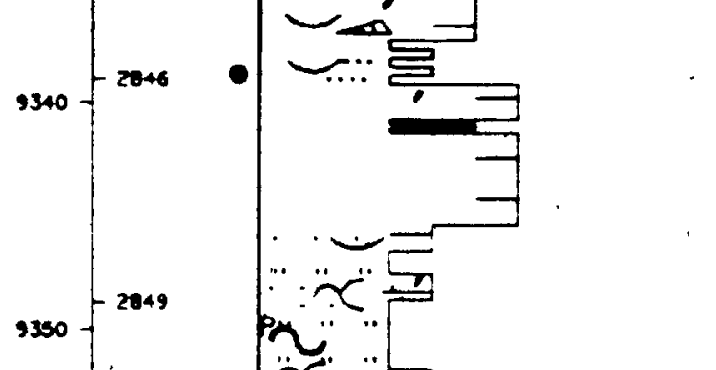

$\infty$

$\infty$

$\omega$

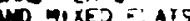

$\infty$
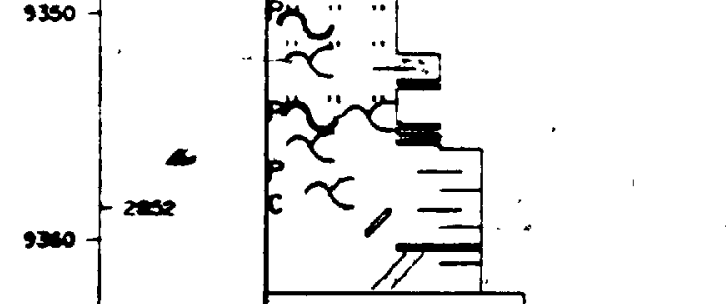

$\infty$

(n)

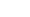

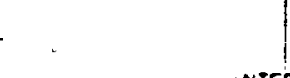

NTERT 'DAL ANO

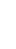

1

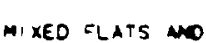

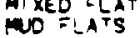

ind

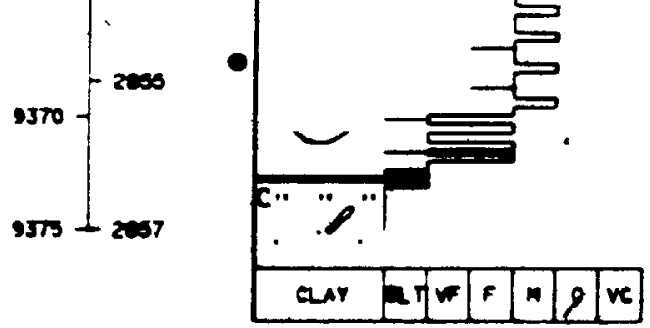

-

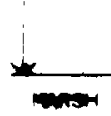

Figure 51. Detalled graphic display of core-Parsons F-09 


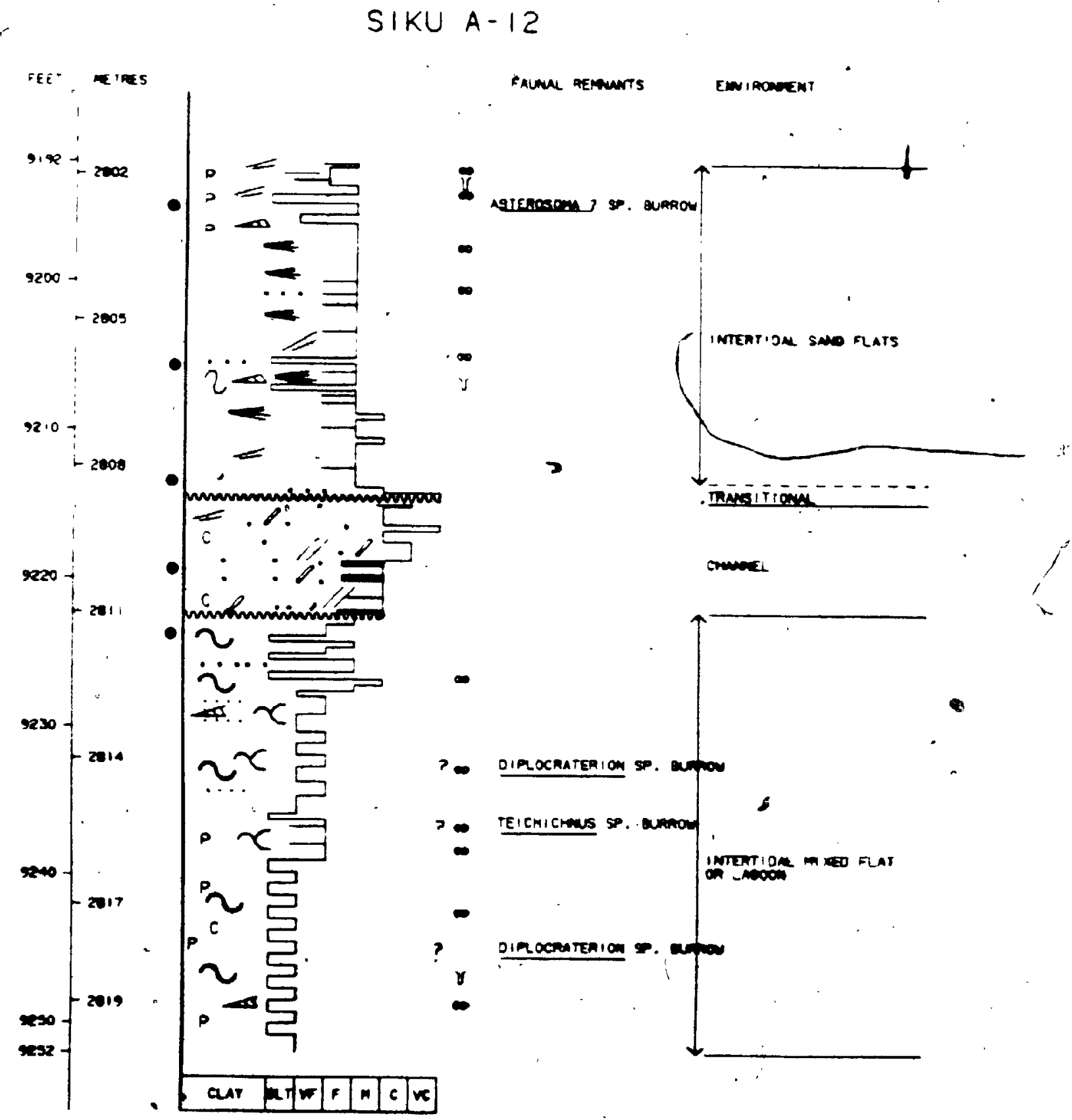

Figure 52. Detalled graphic display of core-Siku $\mathrm{A}-12$ 


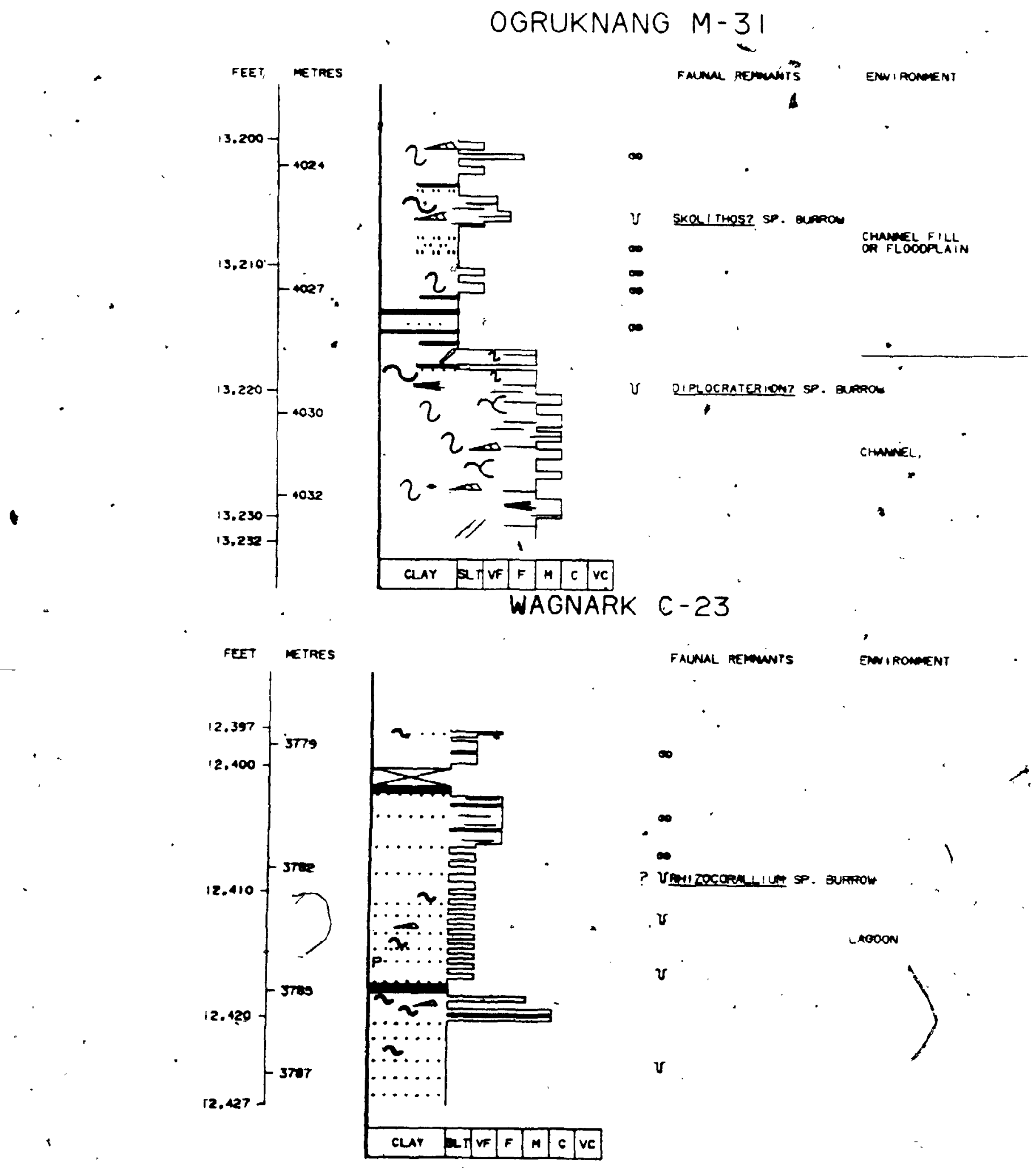

Figure 53. Detailed graphic display of core-Ogruknang M-31 \&Wagnark C-23 


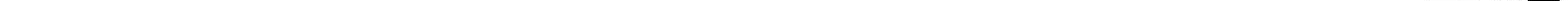


EAST REINDEER A-OI
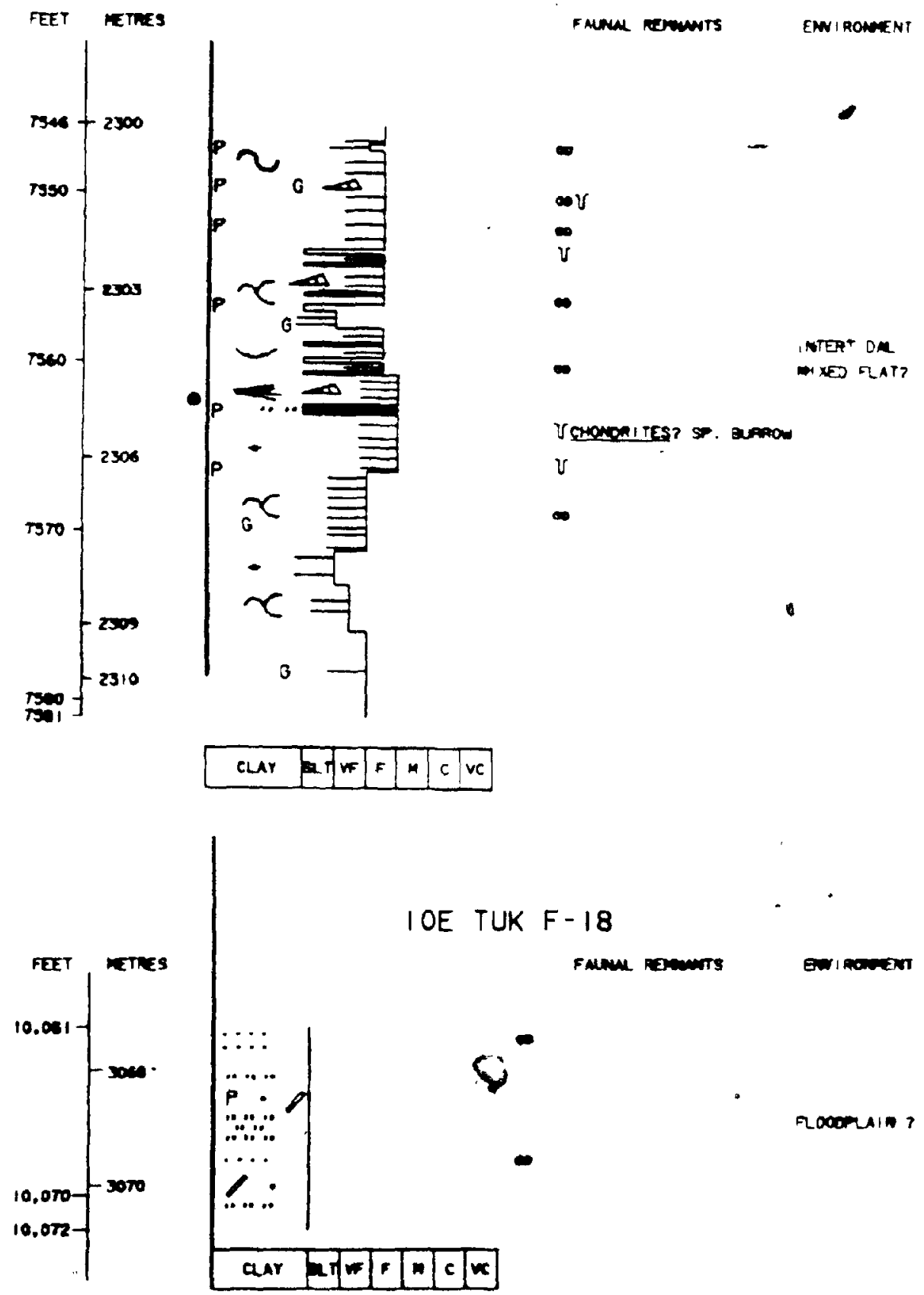

Figure 54. Decafled graphic display of core-Reindeer 1-01 \& IOE Tuk F-18 

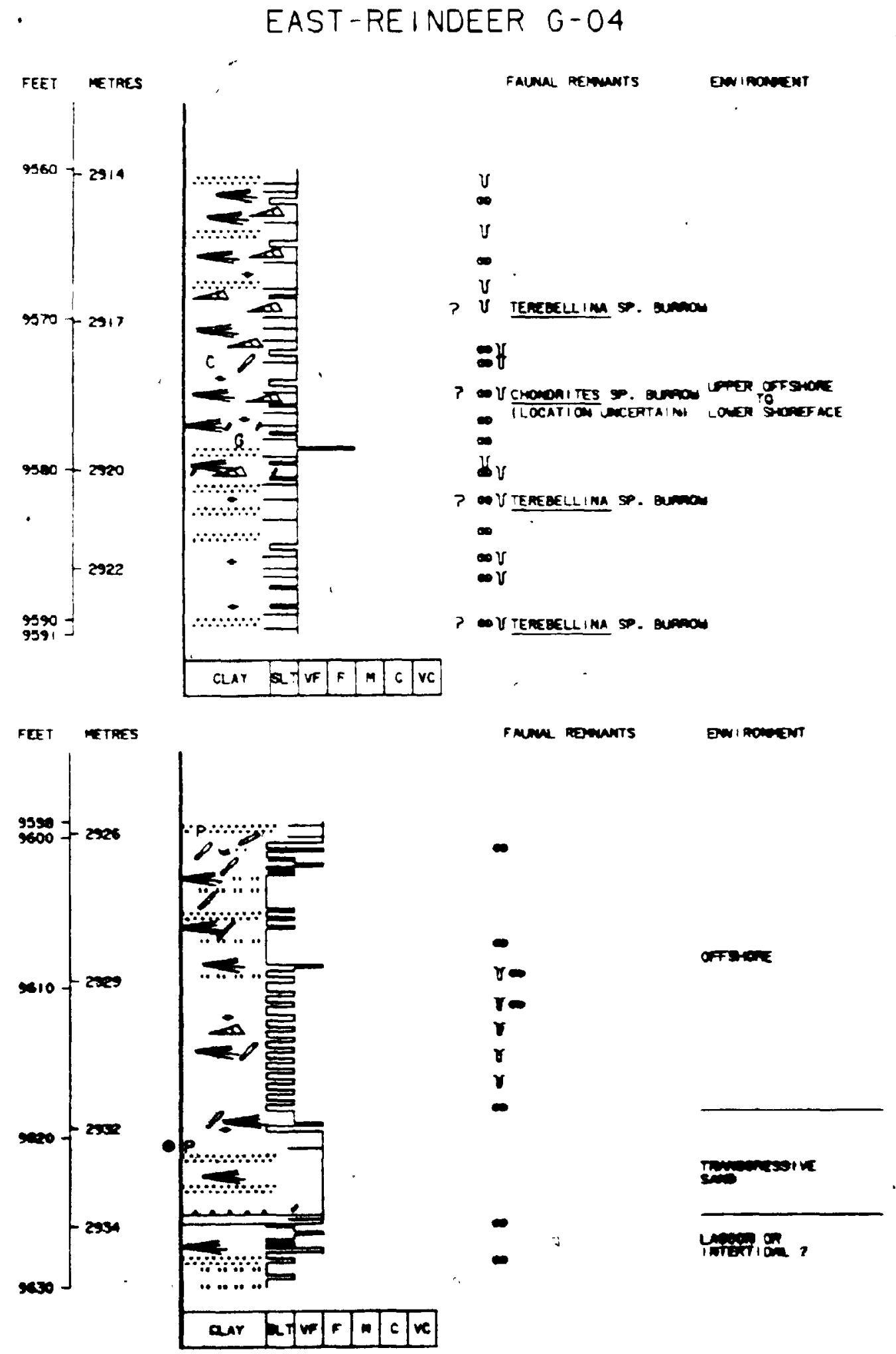
PARSONS $P-41$

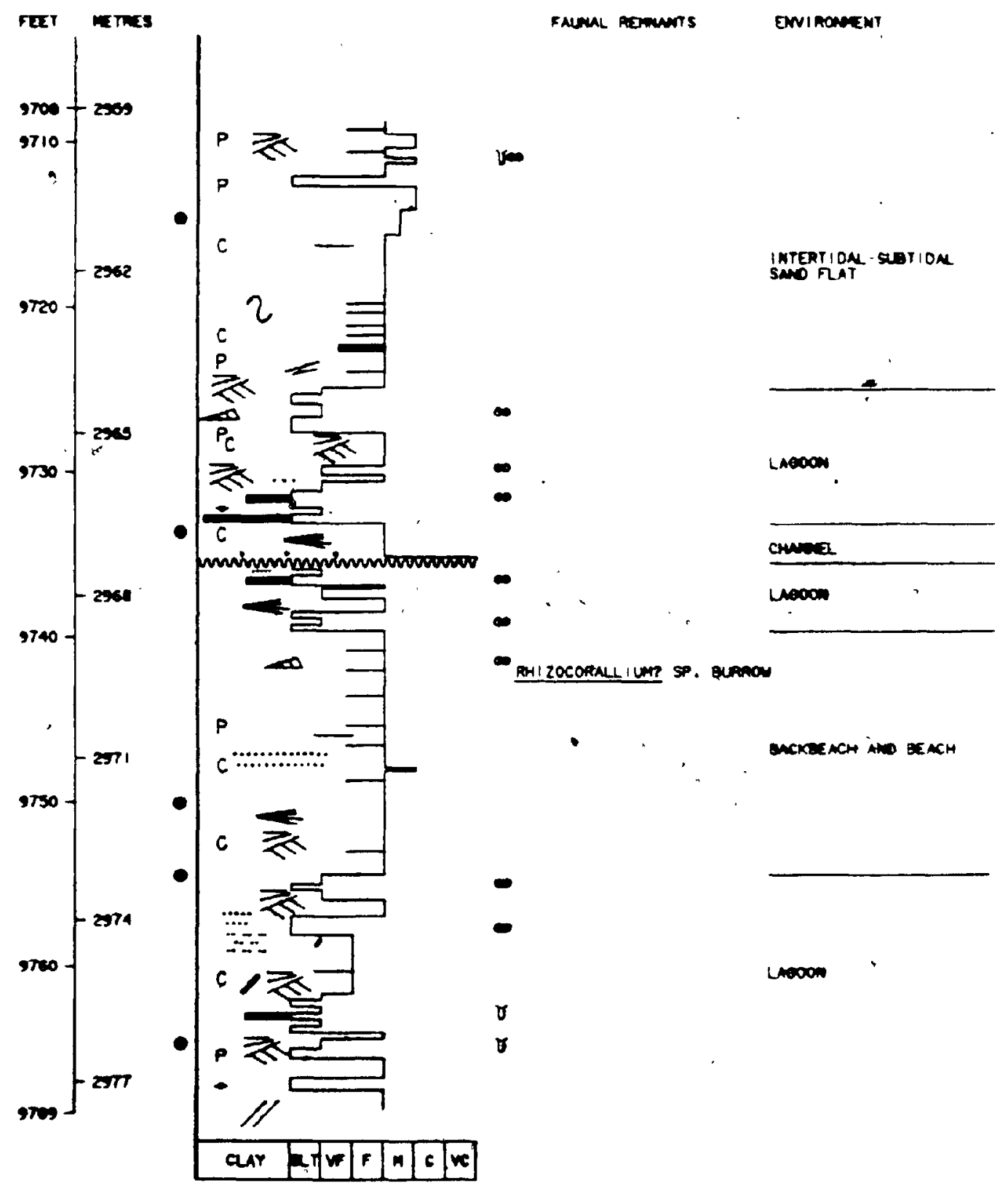

Figure 56. Detalled graphic display of care-Parsons $P-41$ 


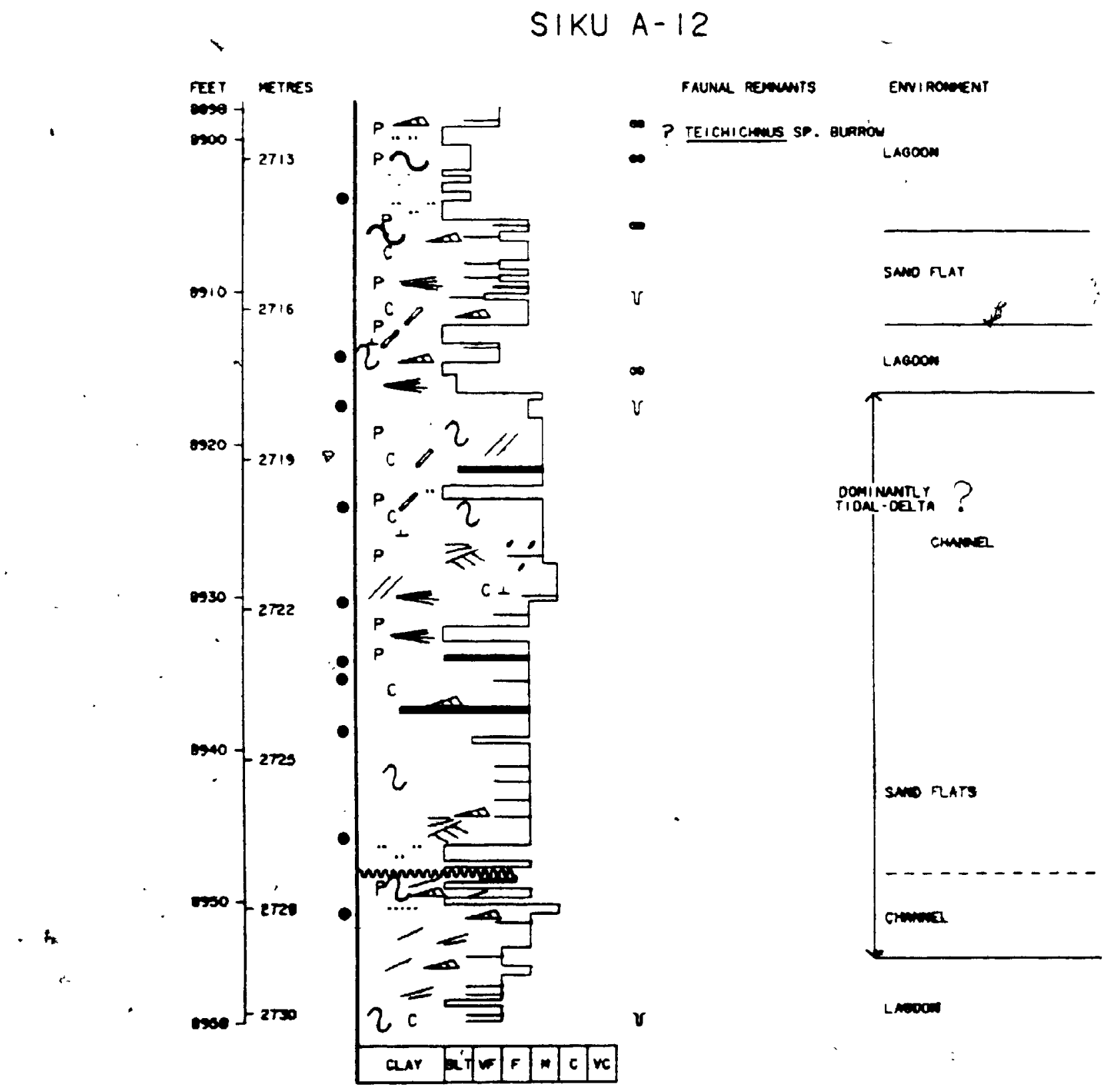

Figure 57. Detailed graphic display of core-Siku $t-12$ 
PARSONS L -43

FEET METRES

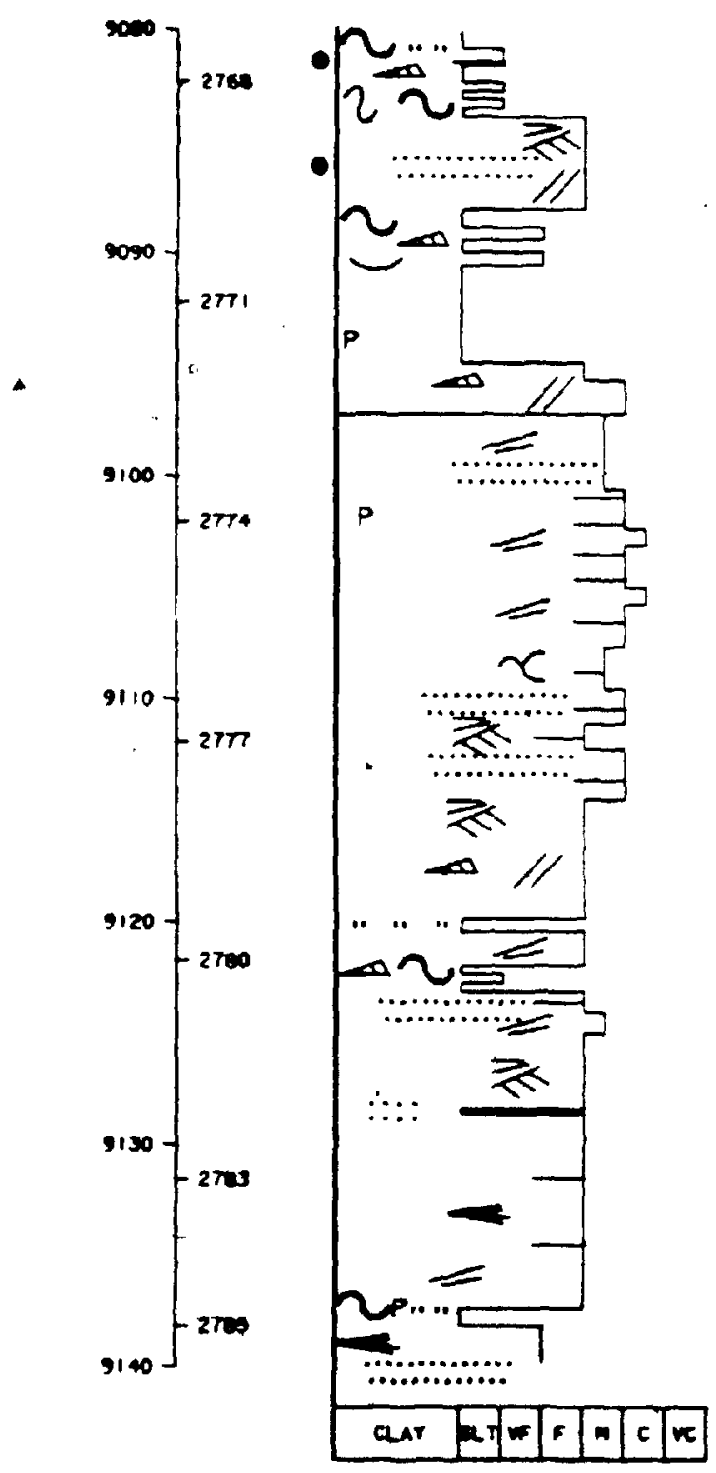

Faumal Remants

ENW I ROAMENT

Is

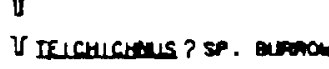

FORESTORE

OFF SHOEE

$\operatorname{arcscons}$

$\infty$

Forestone

UPPeR SHOWEF ACE

Figure 58. Detailed graphic display of core-Parsons L-43 

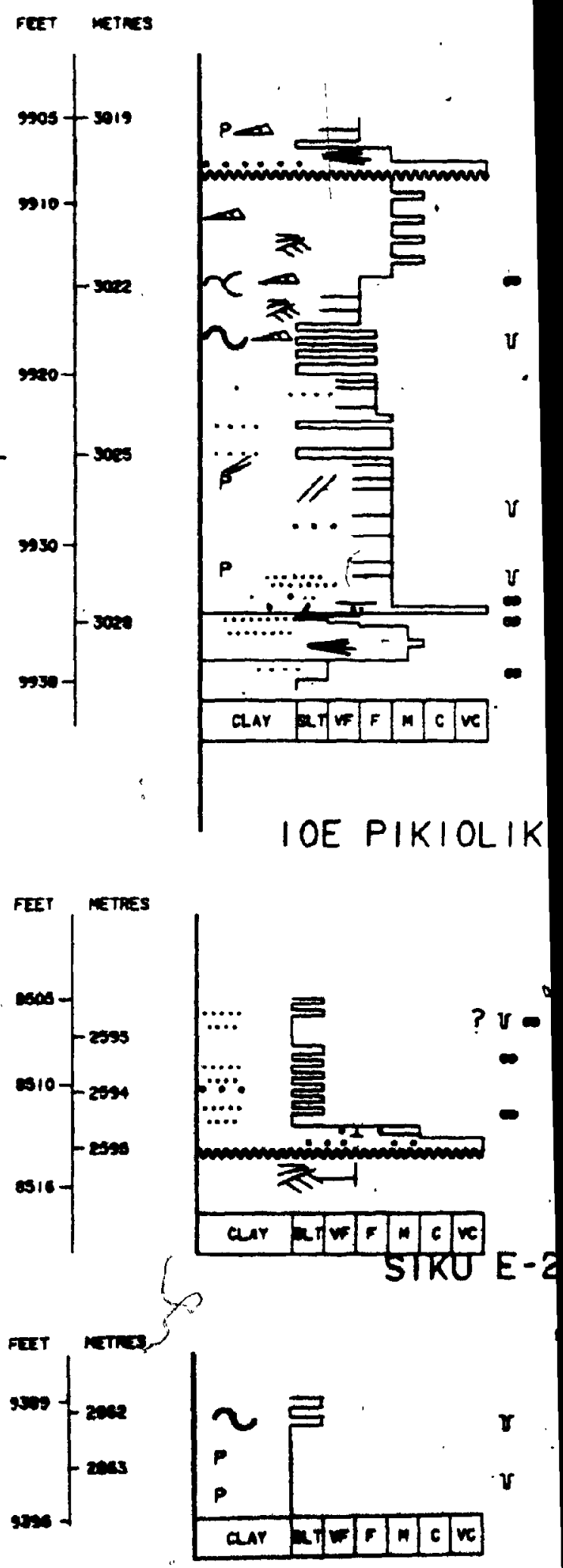

Figure 59. Detalled graphic display IOE PikLO11k E-54\&SIku E-2 
IOE TUK F- 18
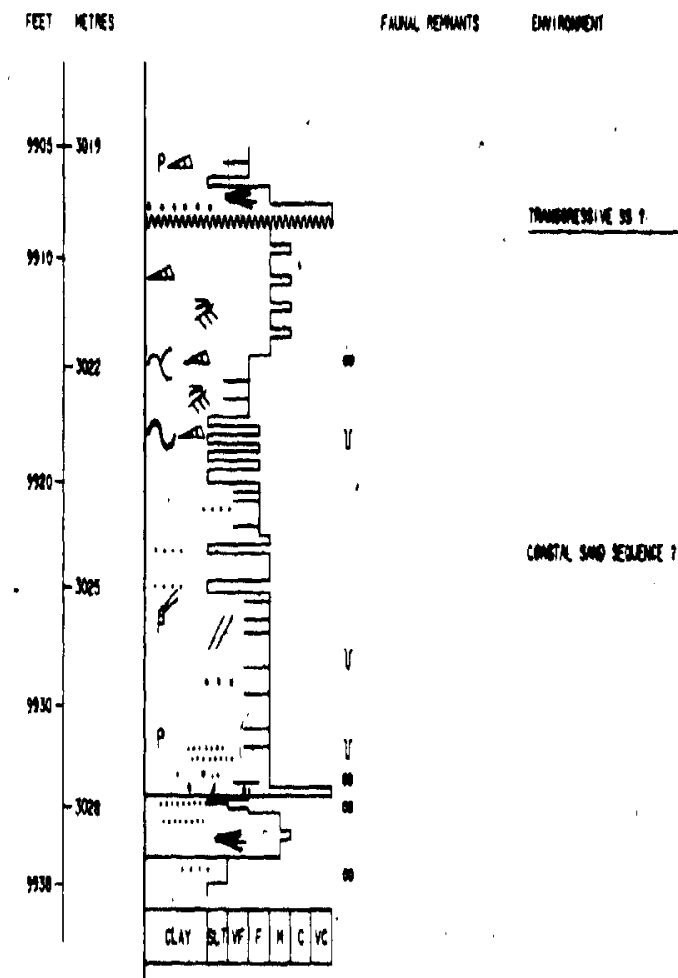

IOE PIKIOLIK E-54
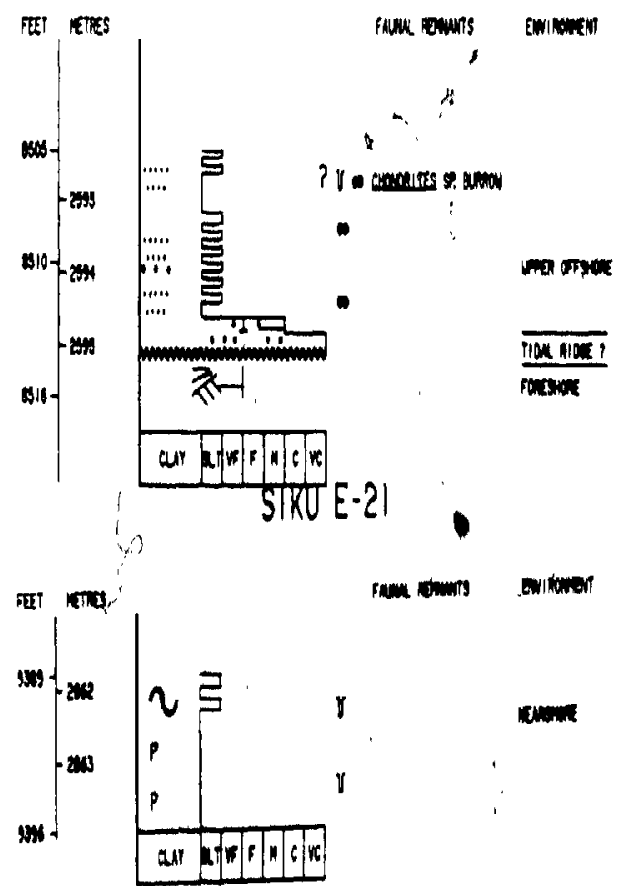

Flzure 59, Detalled graphlc display of core- Ior Tuk :-18, LOE ?iklolik E-546siku E-2! 


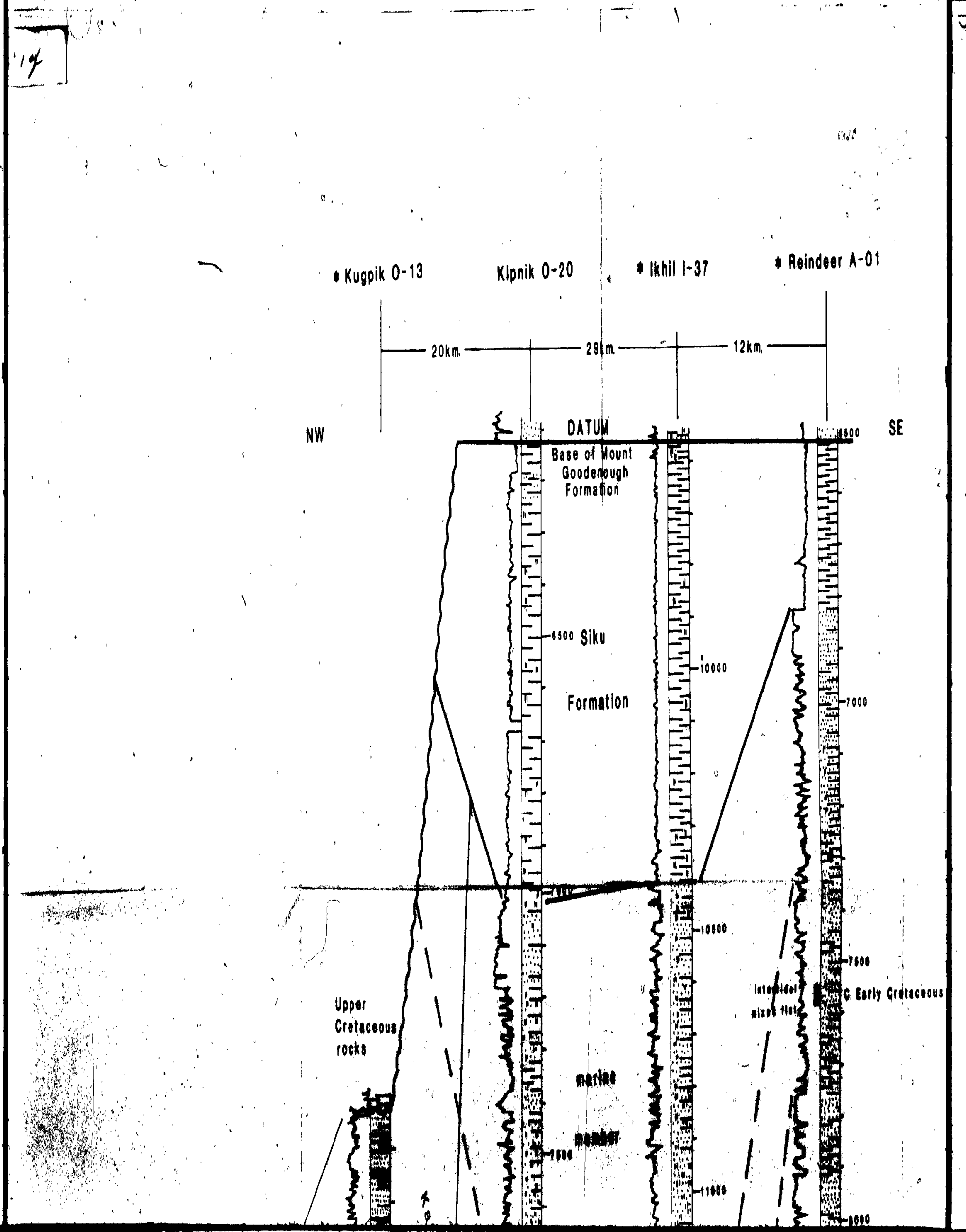




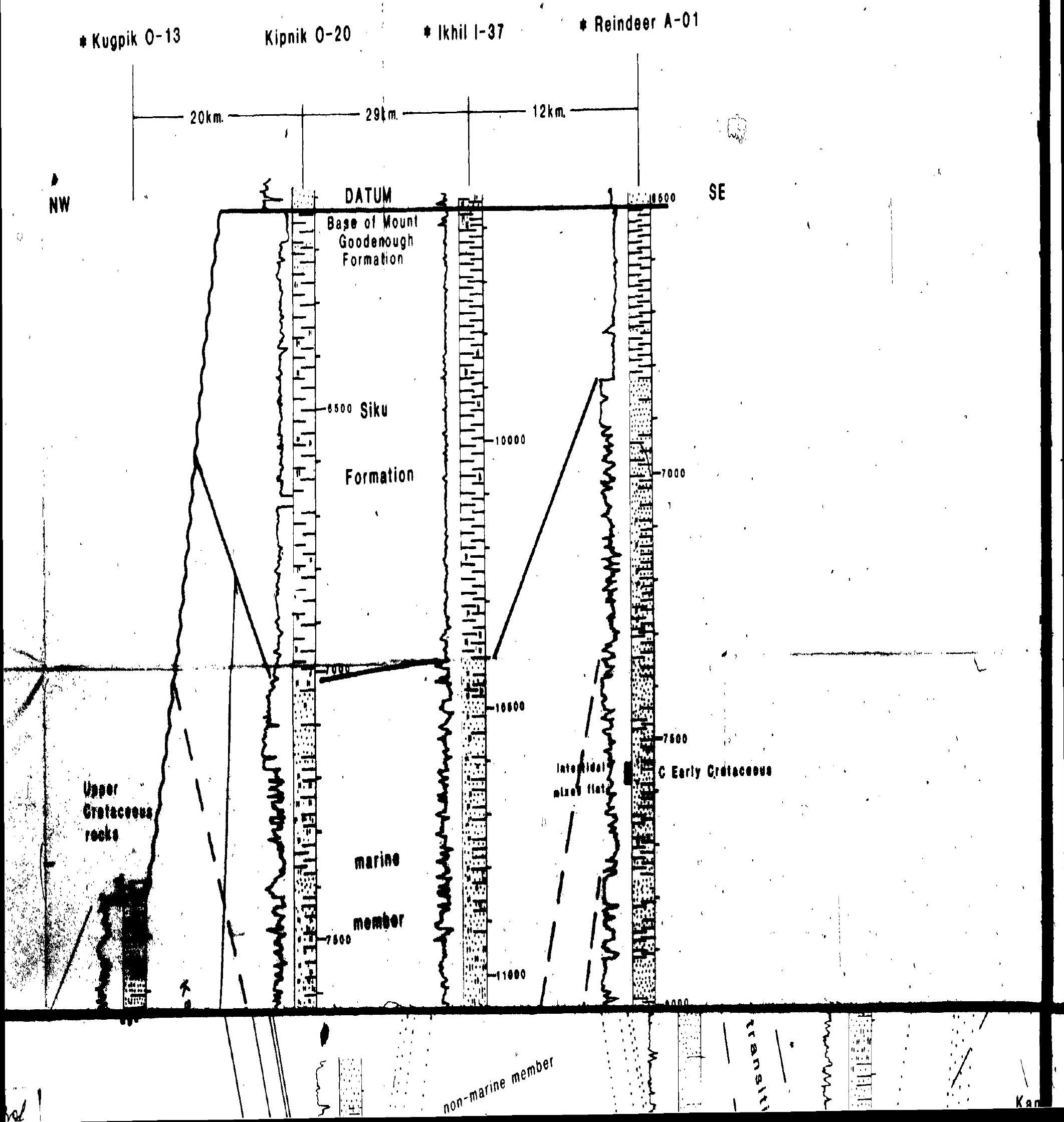




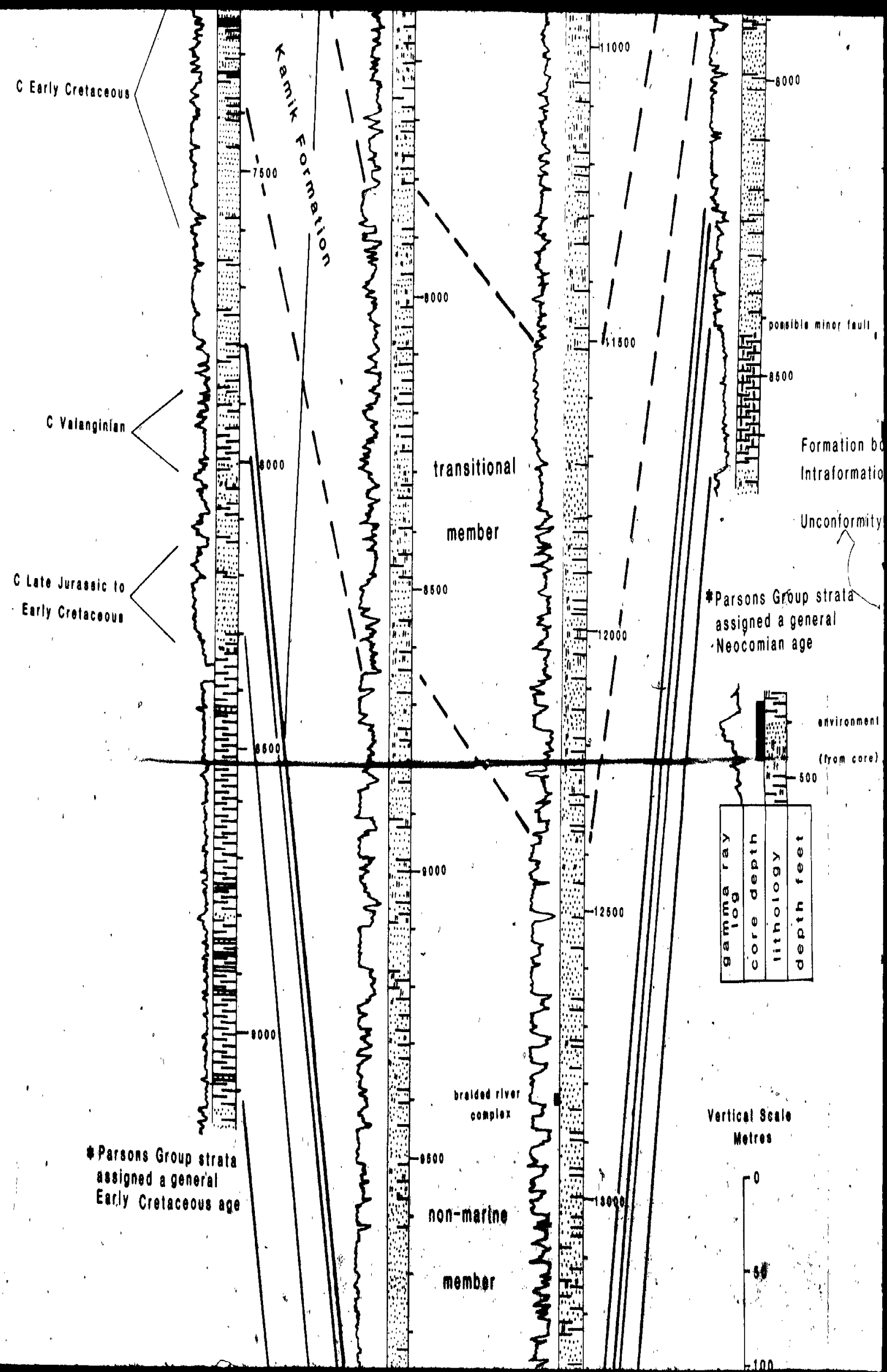




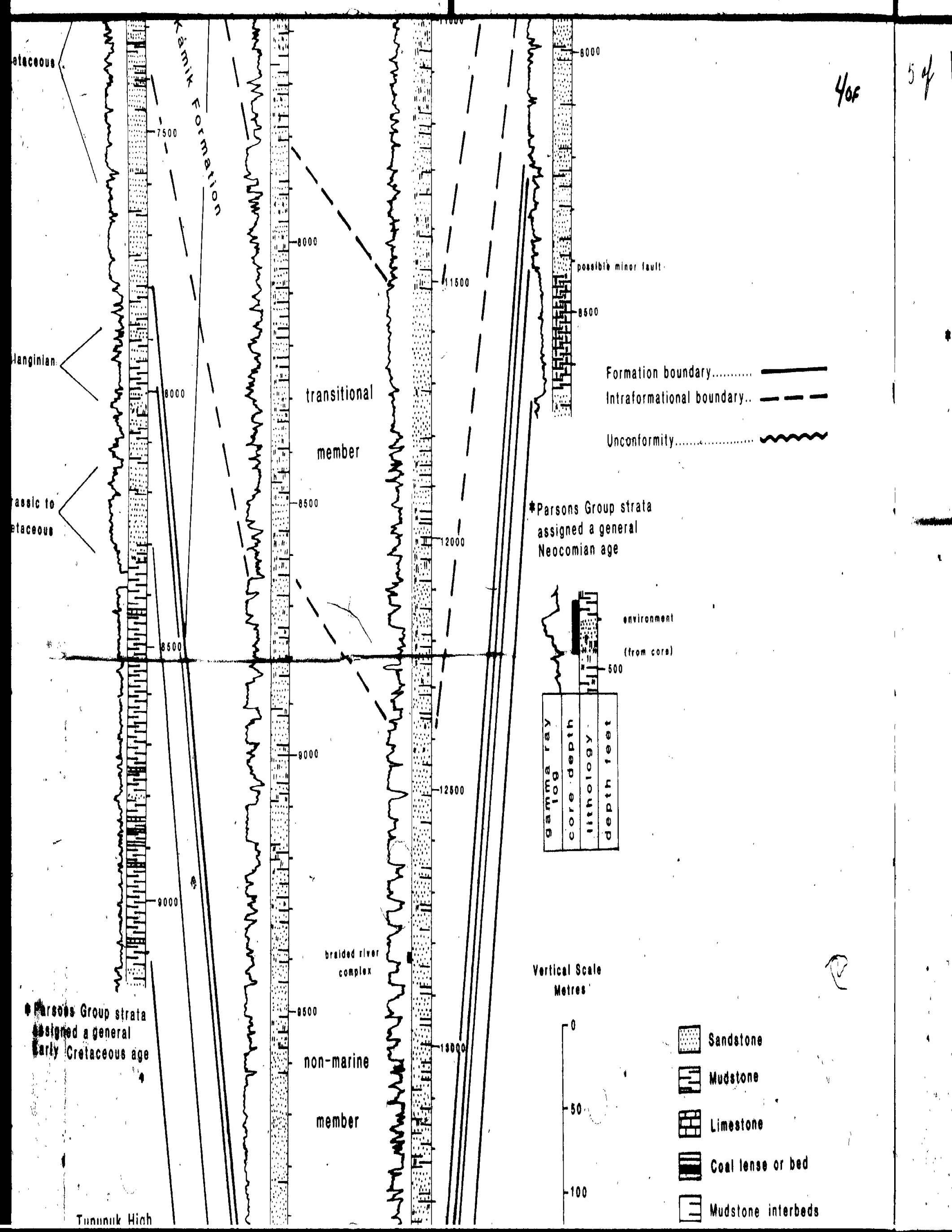


Lithologies given for Reindeer A-0 1 and Kugpik 0-13 from Dixon,1982

* Biostratigraphic determinations on file at Gulf Canada Resources, Calgary.

C Brideaux. al al.,1976

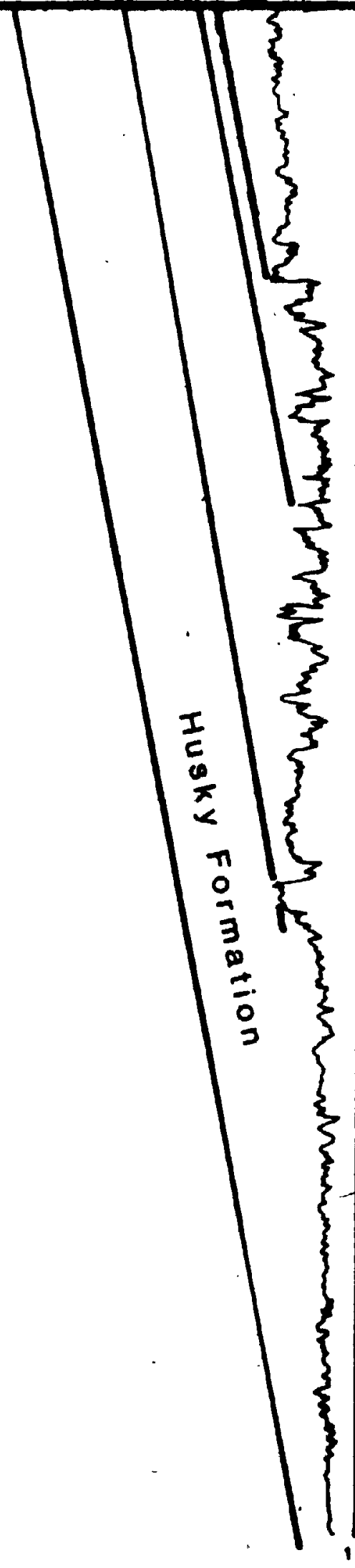

B OTTOM

Kugmal 
Lithologies given for Reindeer A-01 and Kugpik 0-13 from Dixon, 1982

- Biostratigraphic determinations on file at Gulf Canada Resources, Calgary.

C CBrideaux, et Ll. 1976

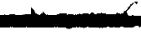

- 


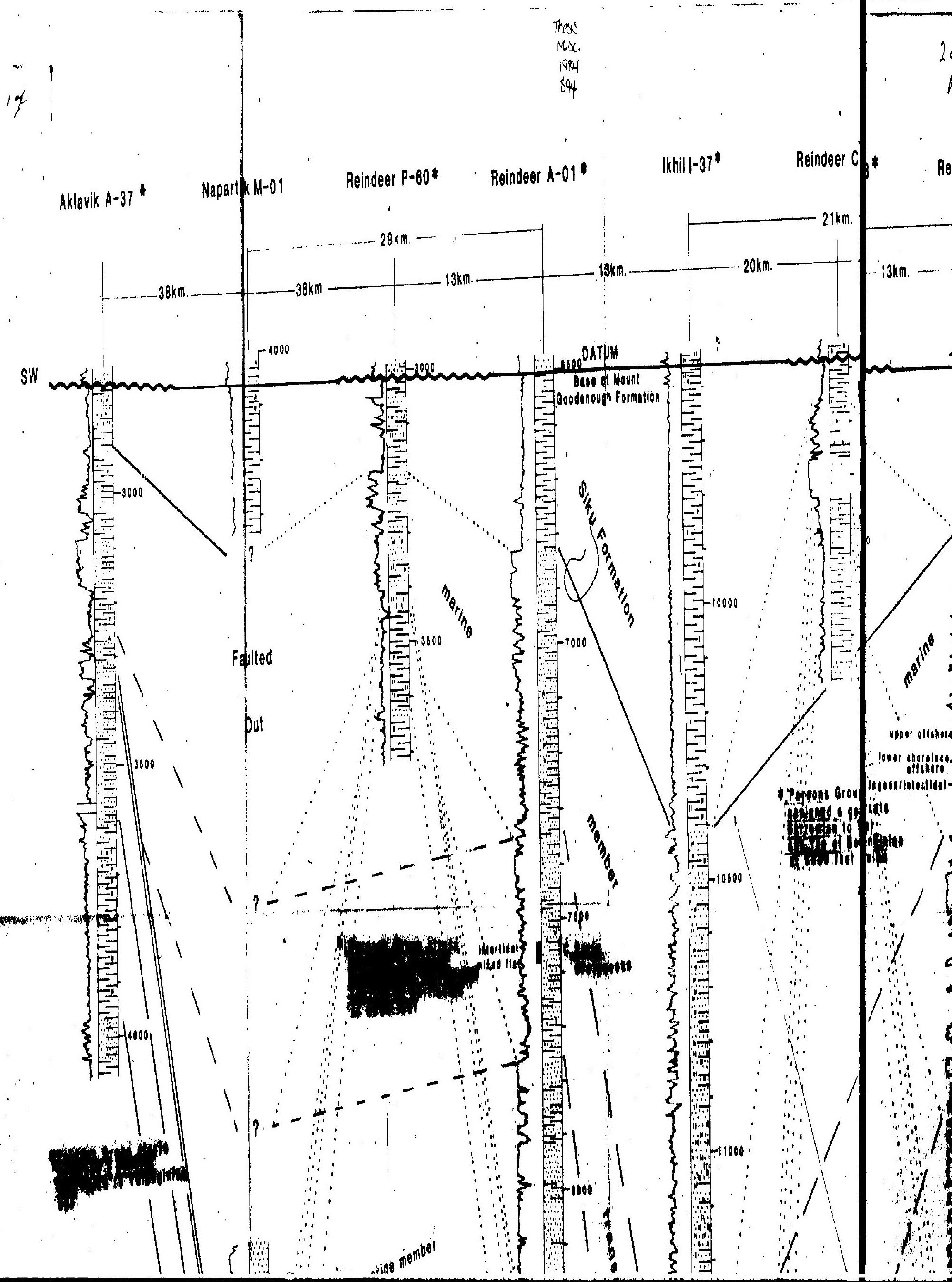




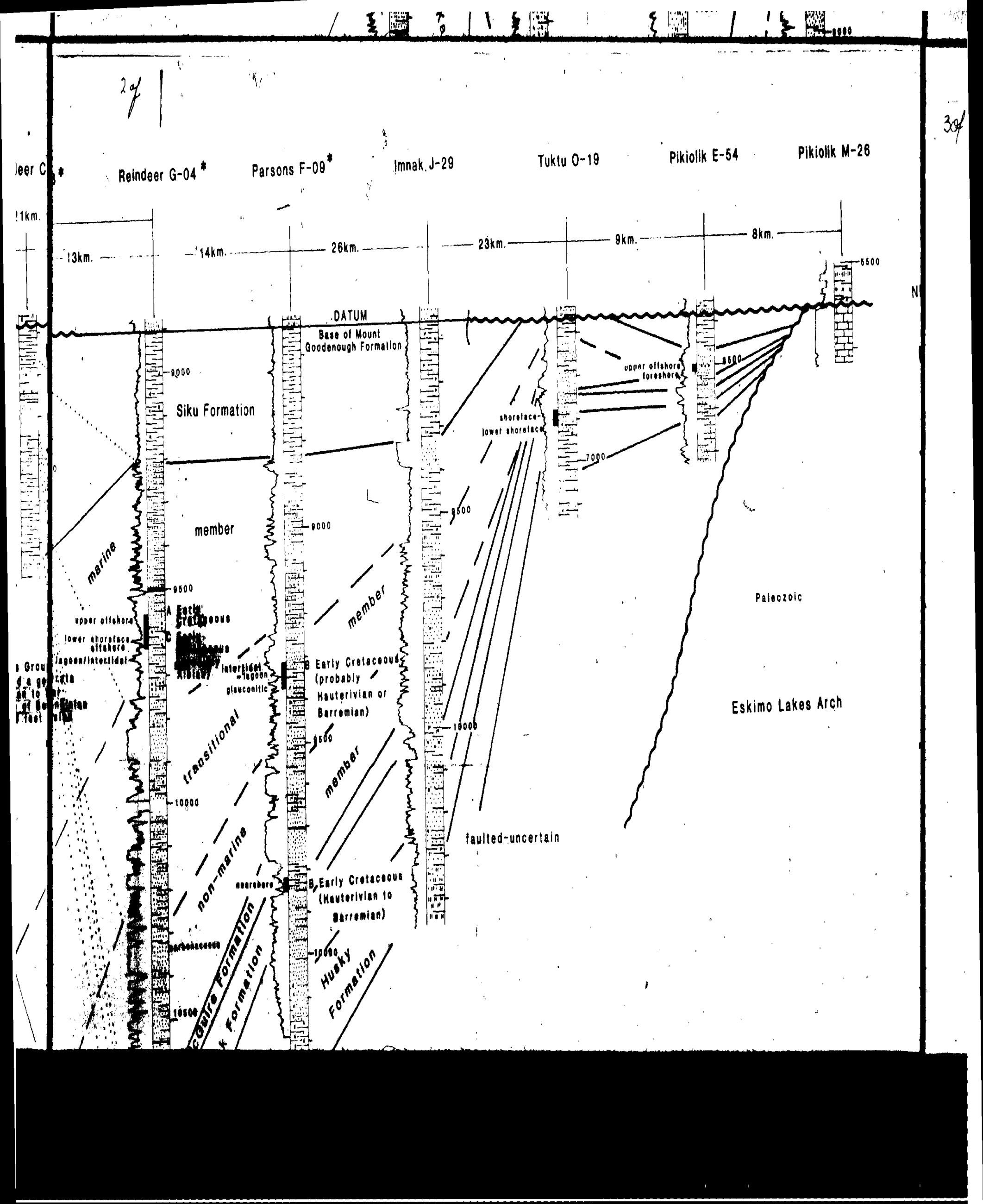




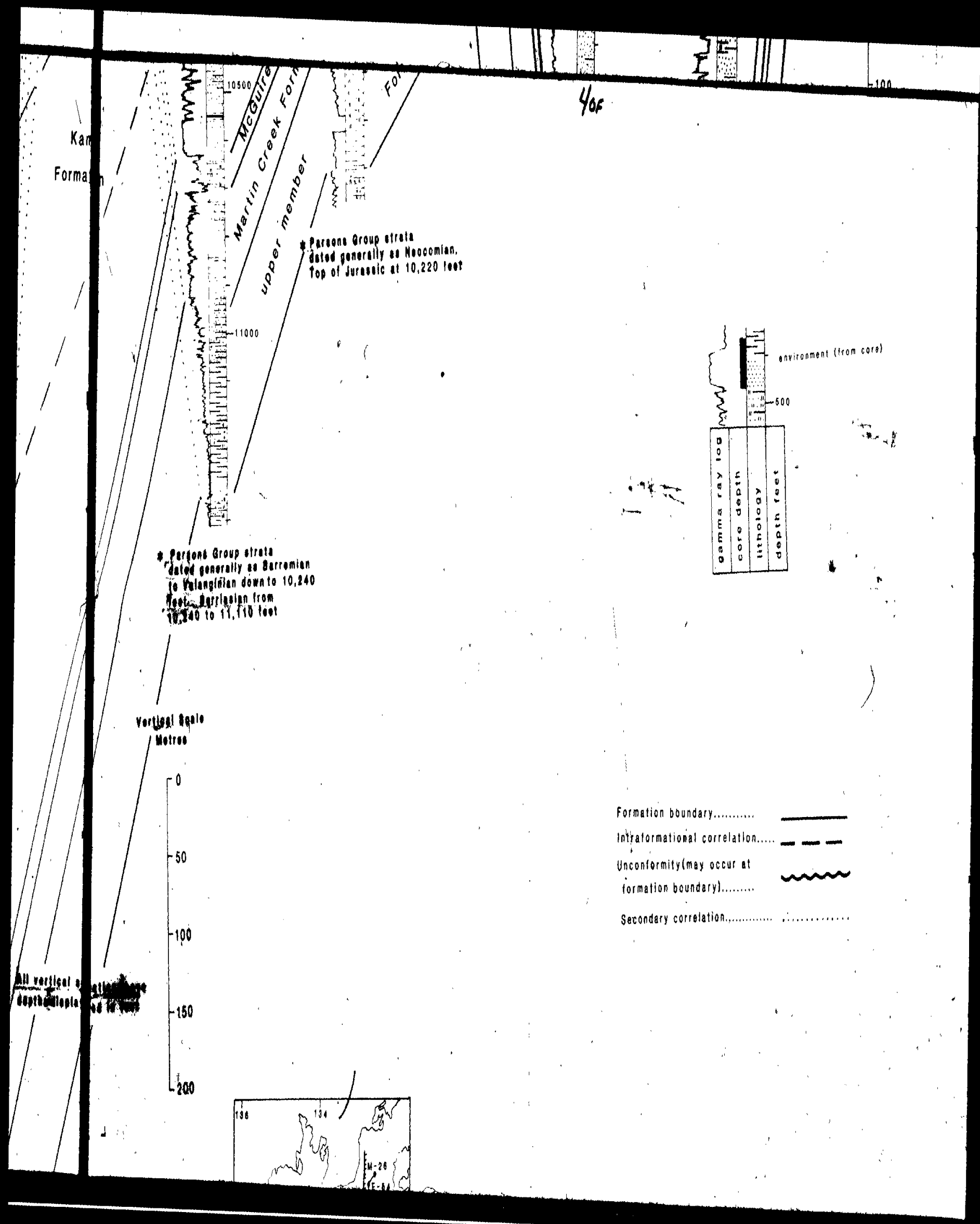




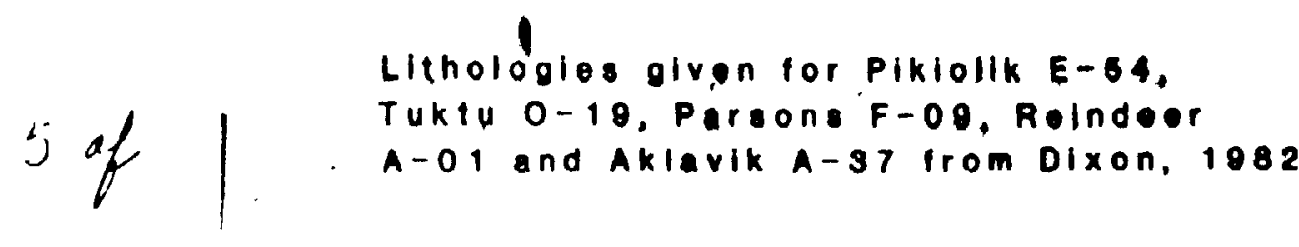
A Barnes et al.,.1874
B Brideaux 요 a…1975
C Brideaux et al...1976

* Biostratigraphic 
1

Llthologles given lor Pikiollk E-64,

Tuktu 0-18, Parsons F-00, Aolndour

A-O and Aklavik A-37 from Dixon, 1982

A Barnes ef al, 1874

B Bridoaux ol al., 1875

C Brideaux el al., 1876

* Biostratigraphic deterthations on file at Gulf Canada Resources, Calgary.
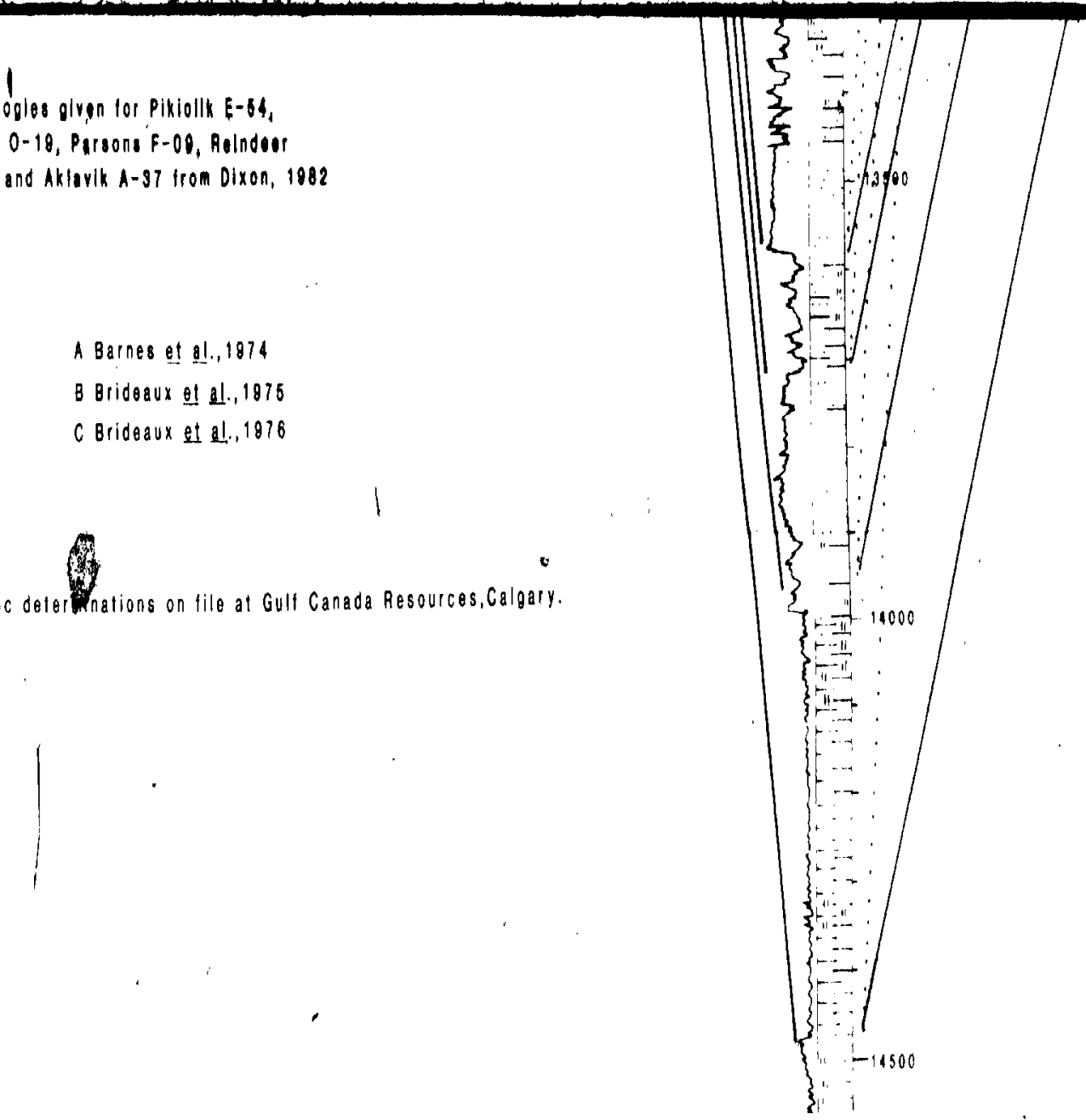

* Perconi group strati

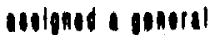

Berrimlan to forriesien

190. Top of Juressic

it 14,850 teot.

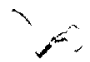

Kugmallit Trough 

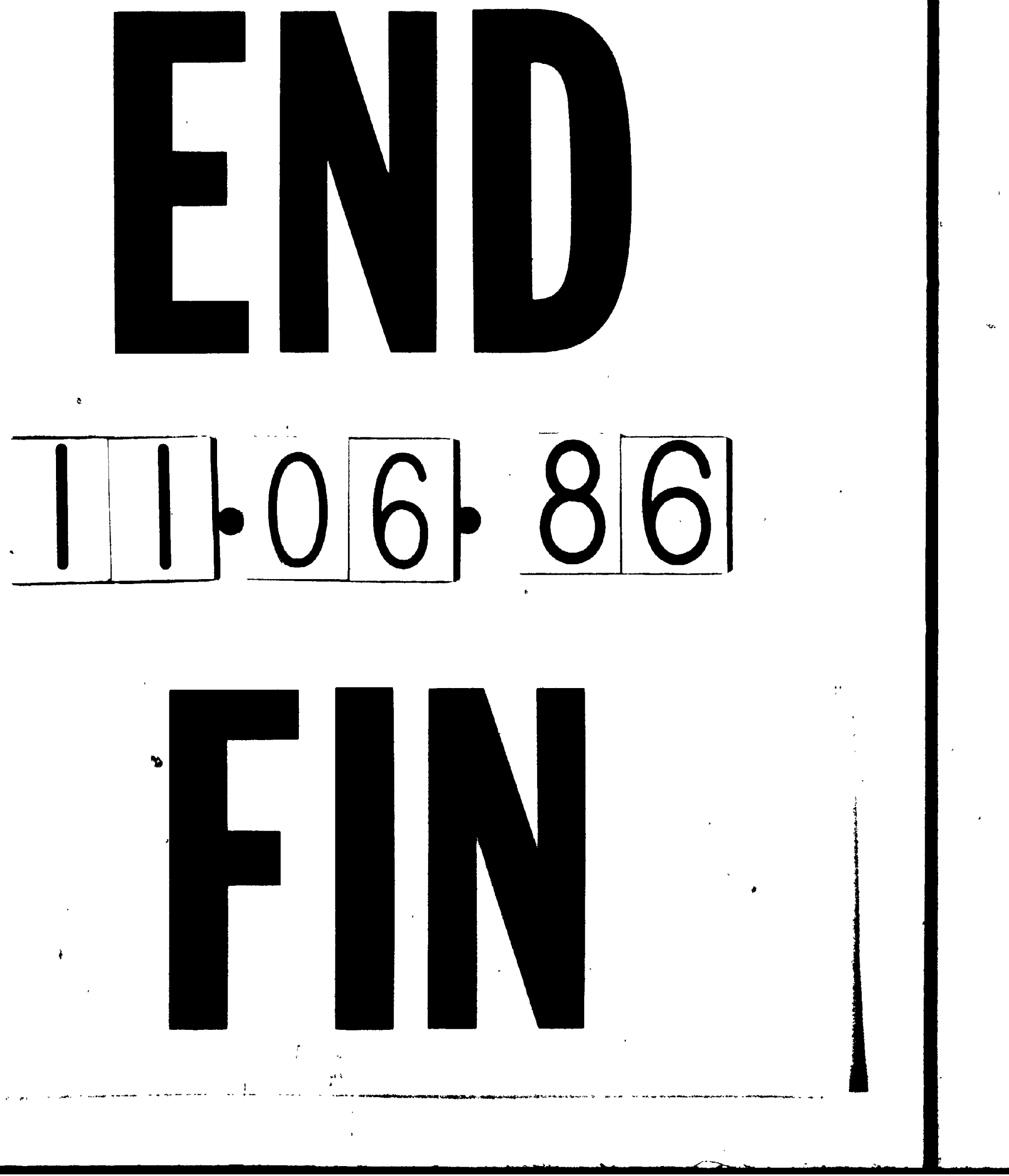
